UNIVERSIDADE DE SÃO PAULO

FACULDADE DE FILOSOFIA, LETRAS E CIÊNCIAS HUMANAS DEPARTAMENTO DE LETRAS CLÁSSICAS E VERNÁCULAS PROGRAMA DE FILOLOGIA E LÍNGUA PORTUGUESA

\title{
CONVERSAÇÃO ELETRÔNICA EM UM GRUPO DE DISCUSSÃO VIA INTERNET
}

Lourdes Fátima Basílio 
UNIVERSIDADE DE SÃO PAULO

FACULDADE DE FILOSOFIA, LETRAS E CIÊNCIAS HUMANAS

DEPARTAMENTO DE LETRAS CLÁSSICAS E VERNÁCULAS

PROGRAMA DE FILOLOGIA E LÍNGUA PORTUGUESA

\section{CONVERSAÇÃO ELETRÔNICA EM UM GRUPO DE DISCUSSÃO VIA INTERNET}

(Edição Revisada)

Lourdes Fátima Basílio

Orientador: Prof. Dr. Hudinilson Urbano

São Paulo

2007

Dissertação apresentada ao Programa de Pós-Graduação em Filologia e Língua Portuguesa do Departamento de Letras Clássicas e Vernáculas da Universidade de São Paulo, para obtenção do título de Mestra em Letras 


\section{Dedicatória}

À Beatriz (in memoriam) por me fazer acreditar que os sonhos são possíveis. Ao Júlio por dar um sentido novo à minha existência. Ao Carlos pela paciência e pelo companheirismo. 


\section{AGRADECIMENTOS}

Ao Prof. Dr Hudinilson Urbano, orientador de duas etapas, professor muito querido, pela atenção e apoio, desde que o conheci em 1994.

À Prof ${ }^{a}$ Dr $^{\mathrm{a}}$ Zilda Gaspar Oliveira de Aquino, pelo excelente curso ministrado na pósgraduação, pelas observações e sugestões feitas no exame de qualificação e pelo carinho demonstrado em todos os momentos.

Ao Prof. Dr. Leland Emerson McCleary pelas observações e sugestões feitas no exame de qualificação, pelos dois cursos da graduação que tive o privilégio de assistir e pela gentileza demonstrada nos vários momentos de discussão e pelos comentários críticos durante a pesquisa.

Ao Prof. Dr. Luiz Antônio Marcuschi pela ajuda e apoio virtuais.

A toda Equipe do Instituto Ayrton Senna pela qualidade do trabalho que tem realizado, não deixando ainda de acreditar em um país no qual, o Índice de Desenvolvimento Humano é mais importante que o Produto Interno Bruto.

Às empresas Microsoft e Gateway que, junto com a pareceria do Instituto Ayrton Senna, viabilizaram o concurso: "Sua escola a 2000 por hora", proporcionando a melhoria na qualidade da educação pública em mais de 800 escolas espalhadas pelo país.

A todos os 824 "listeiros" das escolas parceiras do Programa "Sua escola a 2000 por hora", que têm fomentado discussões, tentado descobrir soluções e auxiliado uns aos outros em um exercício diário de cidadania, do qual tenho o privilégio de fazer parte.

Aos meus familiares: Ananias, José Carlos, Paulo, Ana Cristina, David, Sumaia, Ana Beatriz e Ruben, pelo apoio, ajuda, estímulo e paciência.

À minha irmã e companheira de jornada, Giselle Bueno, pelo estímulo, conversas virtuais e telefônicas, auxílio e o ombro amigo, principalmente nos momentos mais difíceis.

A todos os educadores que acreditam em uma escola pública de qualidade e preparam, todos os dias, jovens para fazer escolhas conscientes, contribuindo para diminuir a distância entre o Brasil que temos e o Brasil que queremos. 
$\mathrm{Na}$ escola dos meus sonhos, os professores são obrigados a fazer periódicos treinamentos e cursos de capacitação e só são admitidos se, além da competência, comungam os princípios fundamentais da proposta pedagógica e didática. Porque é uma escola com ideologia, visão de mundo e perfil definido do que sejam democracia e cidadania. Essa escola não forma consumidores, mas cidadãos.

Não há provas baseadas no prodígio da memória nem na sorte da múltipla escolha. (...) Não há coincidência entre o calendário gregoriano e o curricular. João pode cursar a $5^{\mathrm{a}}$ série em seis meses ou em seis anos, dependendo de sua disponibilidade, aptidão e seus recursos. É mais importante educar do que instruir; formar pessoas que profissionais; ensinar a mudar o mundo que ascender à elite.

$\mathrm{Na}$ escola dos meus sonhos, os professores são bem pagos e não precisam pular de colégio em colégio para se poderem manter. Pois é a escola de uma sociedade em que educação não é privilégio, mas direito universal, e o acesso a ela, dever obrigatório. 


\section{RESUMO}

A presente pesquisa destina-se a mostrar o funcionamento de um grupo de discussão via internet denominado "Lista Provisória dos participantes da Lista de Discussão do programa 'Sua escola a 2000 por hora'”, por meio do estudo das mensagens trocadas entre os seus componentes.

O corpus vem de uma lista educacional ativa, fechada e moderada "de leve". Acredito que o ensino por meio de projetos de aprendizagem, onde o aluno atua como protagonista é fundamental para a melhoria da qualidade do ensino. Essa é a filosofia que norteia os projetos sociais do Instituto Ayrton Senna, e é denominada "Educação para o desenvolvimento humano"

As investigações mostram que as conversações polilógicas (compostas por múltiplos participantes) são mais conflituosas. Assim, acompanhar uma discussão torna-se uma tarefa muito complexa, pois surgem diversos "fios de conversa" e é necessário que o usuário faça, mentalmente, as ligações coesivas entre os enunciados de um mesmo fio.

Uma das questões fundamentais da pesquisa é a discussão sobre conversação eletrônica, em comparação com a conversação natural. Para entender melhor esse conceito, recorro à teoria da Análise da conversação e verifico quais elementos básicos para que a interação verbal se efetive, seja ela uma comunicação mediada ou não. Outra questão que se coloca, partindo-se da noção bakhtiniana de esfera comunicativa, é a questão dos gêneros textuais emergentes na tecnologia digital. Entendendo-se a web como esfera eletrônica, um espaço de práticas humanas de comunicação, acompanho alguns pensadores que acreditam que ela originará muitos gêneros para organizar as práticas linguajeiras ocorridas nesse espaço. Lista de discussão é um desses gêneros.

Atenção especial é dada ao conceito de coesão semântica, como elemento indispensável para o entendimento do fluxo aparentemente caótico de mensagens enviadas ao grupo. Por meio desses elementos construo as teias (conjunto autônomo de fios discursivos dentro da atividade da lista), estabelecendo o subcorpus.

Palavras-chave: comunicação mediada por computador, lista de discussão, gêneros digitais, conversação, coesão. 


\begin{abstract}
This research aims to show how does an internet discussion group named "Lista provisória dos participantes da Lista de Discussão do programa 'Sua escola a 2000 por hora'” work, studying the messages exchanged by its components.

The corpus comes from an active, private and loosely moderated scholar list. I believe that education by learning projects, whereby the student has the main role, is fundamental for the the improvement of the quality of learning. This is the philosophy that guides the social projects of the Instituto Ayrton Senna, and is named "Education for human development".

The investigation showed that polylogical conversations (composed of multiple participants) are more conflictive. Thus, it is a very complex task to follow up a discussion, because diverse threads come out and it is necessary for the user to mentally make the cohesive links between the headers of a same thread.

One of the fundamental issues of the research is the discussion concerning electronic conversation, in comparison to the natural one. In order to better understand this concept, I turned to the Conversation Analysis Theory and verify which are the basic elements for verbal interaction to occur, be it a mediated communication or not. Another issue that arises, departing from the bakhtinian notion of the communicative sphere, is the matter of the emergent textual genre in digital technology. Understanding the web as an electronic sphere, a space of human practices for communication, I follow some intellectuals that believe that it will bring about many genres to organize the language practices that took part in this space. The discussion list is one of those genres.

Special attention is paid to the concept of semantic cohesion, as an essential element for the comprehension of the apparently chaotic flux of messages sent to the group. By those elements I assemble the web (autonomic cluster of discursive threads within the list activity), establishing the subcorpus.
\end{abstract}

Keywords: computer mediated communication, discussion list, digital genres, conversation, cohesion. 


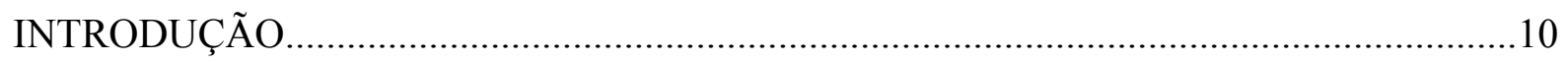

1. EDUCAÇÃO PARA O DESENVOLVIMENTO HUMANO ..........................................23

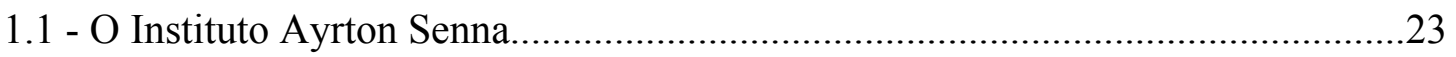

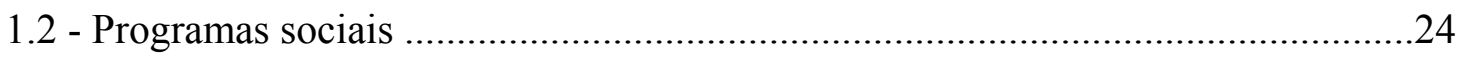

1.3 - Uma ação transformadora sobre o Brasil: o programa "Sua escola a

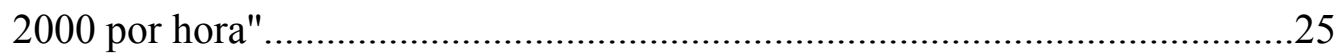

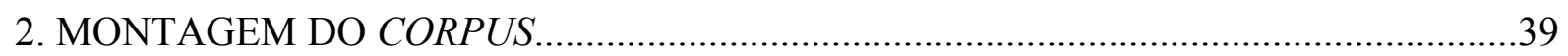

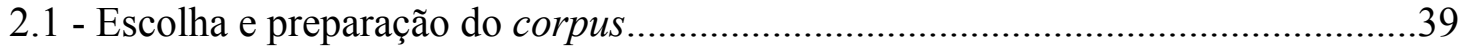

2.2 - O grupo: "Lista Provisória dos Participantes no Projeto 'Sua Escola

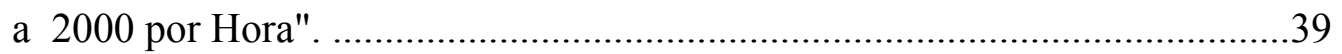

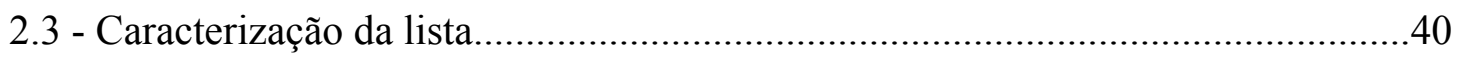

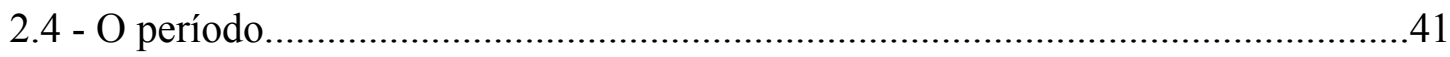

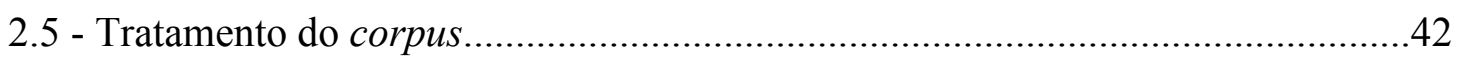

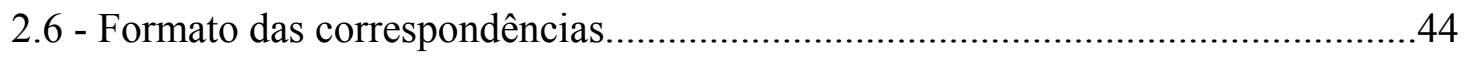

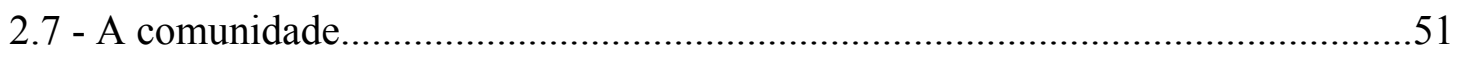

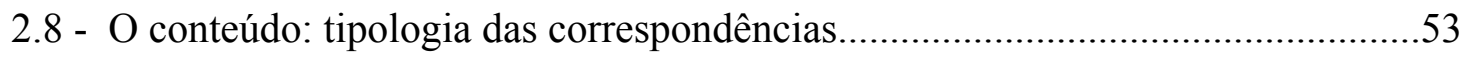

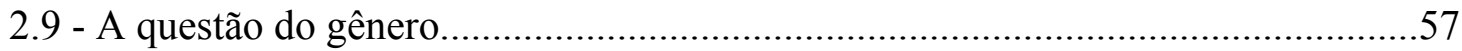

3. A FORMAÇÃO DE UM SUBCORPUS: MONTAGEM DAS TEIAS...............................64

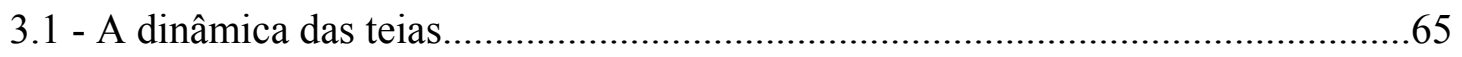

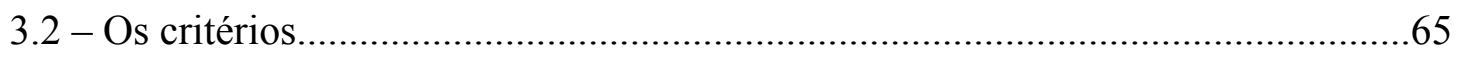

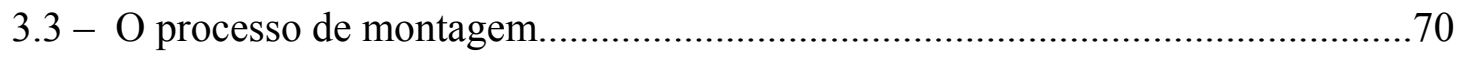

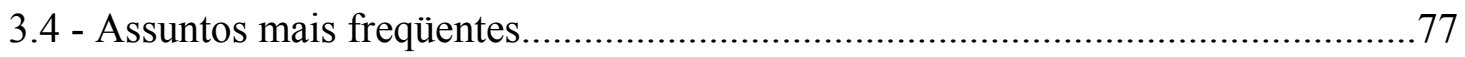

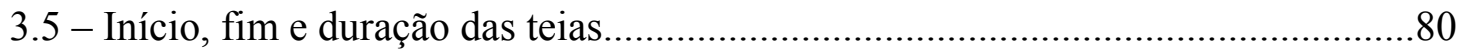


4. A LISTA ESC 2K E A NOÇÃO DE CONVERSAÇÃO ELETRÔNICA.........................93

4.1 - Interação em uma comunidade delimitada........................................................93

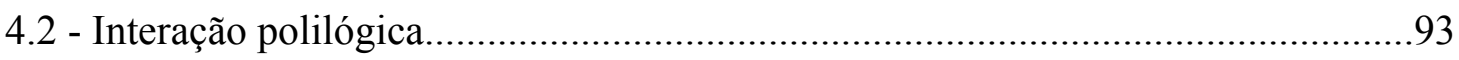

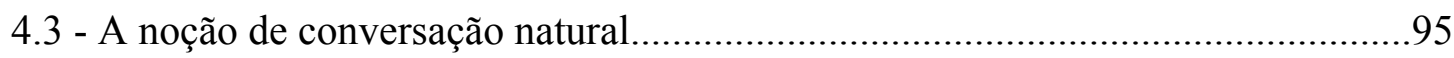

4.4 - A noção de conversação eletrônica......................................................................97

4.5 - Fala e escrita dentro do continuum tipológico....................................................100

4.6 - A localização da conversação eletrônica no continuum tipológico......................104

4.7 - A conversação eletrônica e o sistema de alternância de falantes.........................106

4.8 - A alternância de falantes na lista Esc 2k..........................................................107

\section{RECONSTRUÇÃO DA CONVERSAÇÃO POR MEIO DOS ELEMENTOS DE COESÃO}

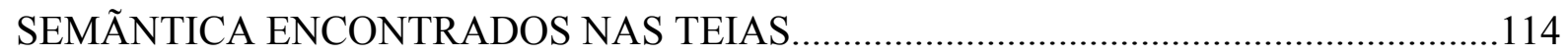

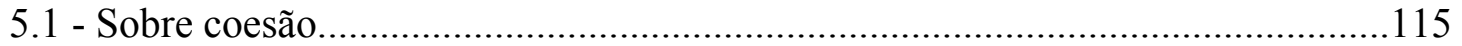

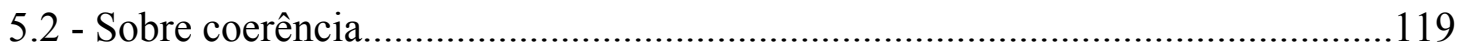

5.3 - Coesão no fluxo de mensagens da lista Esc 2k ..............................................121

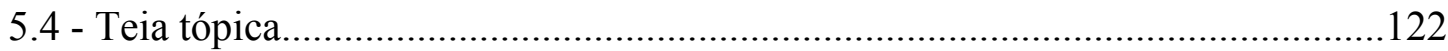

CONCLUSÃO.

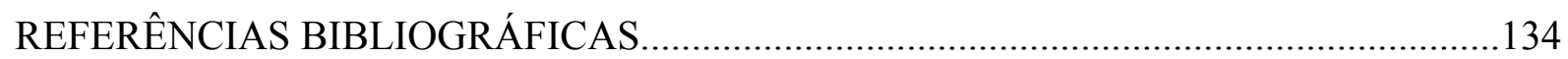

ANEXO 
"A educação é o único fazer capaz de transformar potenciais em competências para viver. Agir em favor das novas gerações, nessa perspectiva, é criar concepções e práticas educacionais que sejam capazes de gerar competências para que os indivíduos transformem a si mesmos e as suas circunstâncias a partir do desenvolvimento pleno de seus potenciais"

(ANDRÉ \& COSTA, 2004:44)

\section{INTRODUÇÃO}

\section{- Tema}

A presente pesquisa destina-se a mostrar o funcionamento de um grupo de discussão via internet denominado "Lista Provisória dos participantes da Lista de Discussão do programa "Sua escola a 2000 por hora”, por meio das mensagens enviadas ao grupo.

\section{- Problema de pesquisa}

Durante a realização do projeto percebi que a participação nesse grupo de discussão era importante para a melhoria do trabalho realizado nas escolas públicas. Assim, entender melhor seu funcionamento, tanto a base de sua filosofia, quanto as ferramentas tecnológicas: como o grupo iniciou e evoluiu, pareceu-me uma proposta desafiadora.

\section{- Hipótese}

Com a pesquisa pretendo descrever e analisar o corpus, observando e explicando a complexidade e o funcionamento da conversação eletrônica na referida lista de discussão, tentando estabelecer um modelo cognitivo.

\section{- Estágio da questão}

No Brasil, a comunicação mediada pelo computador (CMC) tem se tornado alvo de debate acadêmico em várias áreas do conhecimento. Esse debate é pertinente à medida que o uso da internet avança vertiginosamente. Esse país está entre os que mais usam a internet no 
mundo; à sua frente, ficam somente países de Primeiro Mundo e muito avançados tecnologicamente, como EUA, Japão, Reino Unido, Canadá e Alemanha. Percentualmente, porém, tem-se ainda um número baixo de usuários, menos de 5\% (ERCÍLIA, 2000). Além disso, o brasileiro é campeão em horas de navegação, perdendo apenas para os franceses e japoneses (BRASIL, 2005).

Entretanto, os estudos da CMC, sobretudo no âmbito da Lingüística Textual, ainda apresentam-se de forma tímida. Percebi também que ainda há pouco estudo a respeito de lista de discussão, o que, por um lado, dificulta a consulta de bibliografia e a comparação com outros trabalhos, mas, por outro, dá um caráter inédito à pesquisa.

No início dessa pesquisa, fiz um levantamento bibliográfico, e passo a elencar os estudos que considero mais pertinentes. A maioria dos trabalhos que usam a internet como tema, tem se restringido ao estudo dos chats.

Na série de Projetos Paralelos, do Projeto de Estudo da Norma Lingüística Urbana Culta de São Paulo - Núcleo USP, apenas no volume 4 há estudos sobre o assunto (embora a série já esteja no $8^{0}$ volume). Hilgert (2000: 17-55) propõe-se, a partir dos conceitos da Análise da Conversação, discutir as estratégias de construção do texto da conversação na internet, comparando-a com a conversação face a face; Barros (2000:57-77), tendo como referencial teórico a semiótica discursiva, faz uma reflexão sobre as posições intermediárias entre fala e escrita. A autora observa três espécies de bate-papos na internet: IRC (Internet Relay Chat), ICQ ${ }^{1}$ e "aquele em que as pessoas se comunicam oralmente pelo computador" (2000:62).

Ainda na esteira da Análise da Conversação, Barros (2001:355-367) analisa aulas desenvolvidas em salas de bate-papo, denominadas de aulas chat; e Marquesi (2001:369-376) observa a etapa que antecede o diálogo entre professor e aluno via internet.

Destaco também, um dos primeiros trabalhos sobre chat e na linha da Análise da Conversação aqui da FFLCH/USP. Nader (2001) mostra como é diluído o conteúdo informacional nesse tipo de comunicação, que foi classificada de falada-escrita. Além disso a autora analisou as características lingüísticas nos diálogos virtuais, avaliando a troca de turno conversacional, o tópico discursivo, os marcadores conversacionais, o significado das pausas,

\footnotetext{
${ }^{1}$ Programa de comunicação instantânea pela internet que foi o mais popular durante anos. A sigla é um acrônimo feito baseado na pronúncia das letras em inglês (I Seek You), em português, "Eu procuro você". O ICQ foi o pioneiro desta tecnologia tendo sua primeira versão lançada em 1997 . Com a entrada do MSN Messenger, houve uma queda no número de usuários do ICQ.
} 
as falas simultâneas e sobrepostas e as formas utilizadas pelos usuários para expressarem-se melhor na rede, comunicando-se de modo mais afetivo.

No livro Hipertexto e gêneros digitais, todo dedicado ao estudo da CMC sob a ótica dos gêneros, não há nenhum artigo sobre lista/grupo de discussão. Entretanto, no artigo de Marcuschi (2004: 13-67) há uma breve discussão sobre lista de discussão. O objetivo nuclear do trabalho é descrever e analisar as características de vários gêneros textuais que estão surgindo juntamente com as novas demandas tecnológicas. Ainda sob ponto de vista dos gêneros, Machado (s/d:117-128), depois de breve discussão, classifica chat e lista de discussão, como sendo gêneros conversacionais fundados no diálogo.

Marcoccia (2004:115-145) faz um estudo interessante sobre a estrutura da conversação e de participação nos grupos de discussão.

Contribuição importante é dada por McCleary (1996), ao investigar alguns aspectos do discurso gerado dentro de uma lista de discussão acadêmica. Esse trabalho norteou minha pesquisa em muitos momentos.

\section{- Trajetória pessoal como professora-pesquisadora}

Minha experiência docente começou em agosto de 1994 quando ingressei na Rede Estadual de Ensino como OFA (Ocupação de Função Atividade), atual ACT (Admitido em Caráter Temporário). Na época, cursava o segundo ano do curso de Letras (Latim/Português). Embora tivesse pouco conhecimento teórico e nenhuma experiência docente, procurava não cometer os mesmos erros dos meus professores, já que minha experiência como aluna em escolas públicas - cursei o Ensino Fundamental em uma escola municipal e o Ensino Médio em uma escola estadual - não era das mais estimulantes.

Mesmo com os poucos recursos de que dispunha - tanto materiais, quanto pedagógicos - sempre procurei fazer um trabalho de qualidade, pois imaginava meus alunos como a criança que fui um dia e no tipo de aula que gostaria de ter. E desejava proporcionar a eles uma aula mais significativa.

Em 1998, houve concurso público nas Redes Municipal e Estadual de Ensino. Em razão do término da minha graduação em 1997, pude participar das provas, tendo sido aprovada em ambos os concursos. Em outubro de 1999, ingressei no cargo de Professor 
Titular de Ensino Fundamental II e, em fevereiro de 2000, no cargo de Professor de Educação Básica II.

Em outubro de 1999, o Instituto Ayrton Senna, junto com as empresas Microsoft e Gateway, organizou um concurso intitulado "Sua escola a 2000 por hora", envolvendo escolas públicas de cinco estados: Ceará, Distrito Federal, Rio de Janeiro, São Paulo e Rio Grande do Sul. Essas escolas deveriam criar projetos que propusessem o uso da tecnologia como um elemento central da construção de uma nova concepção pedagógica. A premiação consistia em um laboratório de informática composto por sete computadores com acesso à internet e orientação pedagógica pelo prazo de um ano.

$\mathrm{Na}$ época, trabalhava na EE José Lins do Rego, situada na Vila Remo, bairro da periferia de São Paulo. Essa escola não possuía muitos recursos: não tínhamos biblioteca e usávamos uma sala de aula como sala de vídeo; assim, toda vez que algum professor precisava usar a sala, os alunos eram obrigados a fazer revezamento, indo estudar em outra sala. Havia dias em que os alunos eram obrigados a fazer até três trocas de sala. Era muito constrangedor, pois os alunos das outras salas, por não receberem qualquer orientação, praticamente expulsavam os alunos que estudavam na sala de vídeo.

Também não possuíamos laboratório de informática. O que tínhamos era uma pequena sala com cinco computadores, sem acesso à internet. Essa sala vivia trancada, pois alguns professores não conheciam nada de informática e os que conheciam se recusavam a levar alunos para lá, alegando ser impossível trabalhar com um número tão reduzido de máquinas, além de não receberem qualquer incentivo dos coordenadores pedagógicos para fazê-lo.

Diante das dificuldades que enfrentava, acreditei que seria interessante participar do concurso. Se ganhássemos, poderíamos melhorar a qualidade de ensino da escola.

Eu conhecia o relato de um professor de inglês que havia realizado um trabalho interessante com seus alunos. Ele propusera que os alunos lessem as obras de Shakespeare (os textos eram adaptações do original escritas em português). O resultado foi excelente: alguns grupos fizeram seminários e promoveram debates sobre os temas das obras, e um grupo decidiu montar a peça Hamlet.

Conversei com esse professor e com a coordenadora pedagógica, que me deram bastante apoio. Tivemos, então, a idéia de ampliar o projeto para as várias áreas do conhecimento e trabalhar com todas as séries (alunos do Ensino Fundamental II $-5^{\mathrm{a}}$ à $8^{\mathrm{a}}$ série - e do Ensino Médio). No horário de HTPC (horário de trabalho pedagógico coletivo), a 
coordenadora propôs ao grupo de professores presentes a participação no concurso. $\mathrm{O}$ professor de inglês relatou sua experiência no ano anterior com as $3^{\text {as }}$ séries do Ensino Médio, e eu fiz a proposta de ampliarmos o trabalho para todas as séries.

A maioria dos professores não se manifestou, mas alguns foram contra, apoiando o argumento de um deles: nossa clientela é composta por alunos de periferia, que não têm necessidade de saber quem foi Shakespeare ou o que ele produziu. "Eu, que sou professor de matemática, não sei nada sobre ele e, no entanto, tenho formação superior".

Essa fala nos revoltou (a mim, à coordenadora e ao professor de inglês), pois acreditávamos que a escola é um dos poucos caminhos para que o educando se liberte do gueto social, no qual ele está inserido. Esse acontecimento nos impulsionou ainda mais: começamos a conversar com os demais professores da escola e com alguns alunos que aderiram à idéia e escrevemos, em uma paródia com os títulos shakespeareanos, o seguinte projeto: Muito barulho, mas não por nada: o resgate da obra de William Shakespeare e sua relação com o Brasil de hoje. ${ }^{2}$

Ainda no final do ano, fomos contatados por uma equipe do Instituto Ayrton Senna, que nos informou de que nosso projeto tinha sido selecionado, mas, para que ele fosse aprovado, seria necessária a avaliação in loco com os integrantes do projeto. Isso aconteceu em dezembro, e tivemos alguma dificuldade para encontrarmos os alunos participantes, pois alguns já estavam de férias.

Quando retornei das férias em fevereiro de 2000, para minha surpresa, soube que nosso projeto, concorrendo com mil e cem outros inscritos, foi um dos vinte vencedores. A premiação ocorreu na sede da Microsoft em São Paulo com a presença de dois representantes - em geral professores - de cada uma das vinte escolas. A equipe gestora do Instituto Ayrton Senna elaborou uma série de atividades, criando a $1^{\text {a }}$ Semana de Imersão em Tecnologia Educacional - 13 a 17 de março de 2000 - na qual nós tivemos contato com renomados especialistas em educação no Brasil, como Eduardo Chaves (Unicamp) e Léa Fagundes (UFRGS).

Essa semana de capacitação propiciou não só cursos, visitas, palestras e debates, mas também uma aproximação entre os participantes. A intenção desse encontro era a de estreitarmos relações para a segunda etapa que viria a seguir. Como cada dupla de professores

\footnotetext{
${ }^{2}$ Os textos dos projetos vencedores da $1^{\mathrm{a}}$ ed. do concurso está disponível em: $<\underline{\text { http://escola2000.net/eduardo/> }}$
} Acesso em 20/03/2007. 
desenvolveria um projeto em sua respectiva escola, voltaríamos a nos isolar. Entretanto, deveríamos estar em contato permanente com outros representantes e com a equipe de coordenação do Instituto Ayrton Senna. O contato com a equipe de coordenação aconteceria quinzenalmente em cada uma das escolas, sendo destacado um coordenador por Estado participante. O contato entre escolas seria por meio do computador, através de um grupo de discussão ${ }^{3}$, em um ambiente de aprendizagem colaborativa.

A participação nesse grupo, além das orientações que recebia da equipe gestora na escola, fez com que meu trabalho e minha visão de ensino fossem mudando paulatinamente. Deixei de ter uma visão conteudística de educação, ou seja, mera absorção de conteúdos informacionais pelos educandos. Chaves (2000) questiona o modelo conteudístico de ensino e afirma que ele "contradiz virtualmente tudo o que sabemos sobre o que é que motiva as crianças a aprender e como elas de fato aprendem." Litto (s/d) opõe aprendizagem "profunda" (compreensão consolidada das matérias, permitindo transferência de um domínio para outro) a aprendizagem "de superfície" (memorização de fatos) e explica que o papel do professor não é mais a transferência do conhecimento, e sim criar projetos organizados em torno de resoluções de problemas, que levem os alunos a descobrirem conhecimentos novos.

Na prática, fui percebendo que esse modelo tradicional de educação, também chamado de aprendizagem mecânica pelos cognitivistas (BOCK, FURTADO e TEIXEIRA, 1995: 102), não funciona e fui adotando uma postura que leva em conta as habilidades e competências dos alunos, ou seja, substituí esse modelo pela aprendizagem significativa. Sobre esse fato, Chaves argumenta que a criança tem muito prazer em aprender, quando é pequena e ainda não passou pelo processo escolar e se, ao entrar na escola, o aprendizado subitamente se torna aborrecido e até mesmo sofrido, isso acontece por falha da escola, já que nada fundamental se altera nela.

Além disso, seu aprendizado agora deve se processar principalmente no ambiente organizado e estruturado da escola, que muda drasticamente a natureza do processo de aprendizagem, pois a relação entre processos cognitivos e processos vitais, ou seja, aprendizagem e experiência, acaba.

Buscando melhoria na qualidade do meu trabalho, realizei alguns cursos que me auxiliaram no desenvolvimento de alguns projetos. ${ }^{4}$ A partir de então, e sob forte influência

\footnotetext{
${ }^{3}$ A história desse grupo será relatada no próximo capítulo.

${ }^{4}$ A educação por projetos é base indispensável das ações educativas propostas pelo IAS (André \& Costa, 2004:131).
} 
do programa "Sua escola a 2000 por hora", passei a trabalhar com projetos de aprendizagem. Citarei alguns cursos que considero mais importantes e pertinentes: Curso Introdutório à História da Arte a partir da Coleção do MASP; Curso Intersecretarial Optativo - Teatro: elementos formais, temáticos, diferentes linguagens e formas de expressão; Vivências Culturais para Educadores e Bem-vindo professor.

Esses cursos foram realizados no período em que trabalhei na EMEF Prof ${ }^{\mathrm{a}}$ Carolina Rennó Ribeiro de Oliveira, ao ingressar na Rede Municipal de Ensino em outubro de 1999.

Ao iniciar minha experiência nessa escola, juntamente com a experiência no magistério em geral (desde 1994), percebi um distanciamento muito grande entre as pessoas que vivem na periferia de São Paulo e as instituições culturais (Teatro/Museu). Com os conteúdos adquiridos nesses cursos, desenvolvi, desde 2001, um projeto pessoal para aproximar os alunos dessas instituições.

Em 2001, eu e as professoras de História e Arte fizemos um trabalho na escola que durou cerca de um mês e, como encerramento, visitamos a exposição "Egito Faraônico terra dos deuses" no Masp. As atividades que eu desenvolvi foram: leitura de mitos e lendas sobre o Egito Antigo com a intenção de produzir peças teatrais (teatro de fantoches e teatro de sombras); reprodução de alguns deuses egípcios em tamanho natural e exibição nas paredes da escola, juntamente com textos explicativos sobre sua origem e função; correlação aproximada dos hieróglifos e as letras do nosso alfabeto. Esta atividade, que começou de forma lúdica, fez com que os alunos passassem a escrever seus nomes com essa escrita, além de render uma gincana onde os alunos deveriam decifrar um texto hieroglífico. Durante as aulas, eu falei muito sobre a importância arquitetônica do prédio do MASP, o que também motivou a visita dos alunos ao museu.

Em 2002, fiz um trabalho na escola envolvendo Português/Arte. Os alunos leram biografias de vários pintores, assistiram a vídeos sobre a vida e obra deles e produziram pequenas monografias. Fizeram várias provinhas e testes. Fizeram ainda leitura de obras de arte, ou seja, descreveram o que entendiam das reproduções de alguns quadros. Os alunos mostravam-se cada dia mais interessados em conhecer arte, e era comum eu receber depoimentos espontâneos no corpo das monografias, como estes: "agora eu gosto de arte", "agora eu entendo o que é arte", "as aulas estão muito legais", etc.

Também aconteceu um fato curioso: na época foi lançado o carro Xsara: Picasso. Descrevo o comercial. Em uma linha de montagem de carros, feita apenas por máquinas, estas 
pintam toda a carroceria com desenhos no estilo de Picasso. Momentos depois, entram dois seres humanos no local, e as máquinas pintam a carroceria com uma cor única, fazendo desaparecer a obra de arte que tinham feito, deixando apenas o nome Picasso, na forma em que o pintor assinava. Assim que fizeram a associação, não só porque já tinham lido e assistido a um vídeo sobre a vida e a obra do artista, mas também porque a capa dos livros de pintores que eles liam tinha sempre a reprodução da assinatura do artista, vários alunos ficaram muito felizes com a descoberta, pois haviam entendido a propaganda.

Além de todas essas atividades, fiz um trabalho, de cerca de um mês, antes de visitarmos a exposição Renoir - o pintor da vida também no Masp: tivemos aula no ateliê sobre técnicas de gravura em pedra, madeira e metal, pois, além da pintura, Renoir praticou litogravura e xilogravura. Os alunos também leram artigos em jornais e revistas da época que falavam sobre a exposição.

Nesse mesmo ano, os alunos visitaram a exposição 500 anos de arte russa na Oca (Pavilhão Lucas Nogueira Garcez - localizado no Ibirapuera). Mesmo tendo participado do Curso Preparatório para Professores e Líderes Comunitários para a exposição (o que não ajudou muito), tive bastante dificuldade em obter material para trabalhar com os alunos. A solução foi contentar-me com artigos em jornais e revistas da época que falavam sobre a exposição, os quais, na maioria das vezes, apenas repetiam o que estava escrito em outro artigo. Ainda assim acredito que consegui realizar um bom trabalho. Algumas das atividades foram: relacionar imagens das obras a frases retiradas de um artigo; relacionar frases-síntese a cada um dos parágrafos de um outro artigo; relacionar palavras ou expressões retiradas do texto com seu respectivo significado.

Os alunos também puderam conhecer a linguagem teatral e assistiram, por exemplo, às peças A farsa do advogado Patelin (de autor desconhecido) e $A$ mandrágora (de Nicolau Maquiavel), ambas no Teatro João Caetano. Como mais de 95\% dos alunos nunca haviam entrado em um teatro, falei um pouco sobre a linguagem teatral, usando como contraponto a linguagem cinematográfica, que era a única que eles conheciam. No caso da segunda das apresentações, aproveitei para falar também sobre o autor Maquiavel e suas peças. Finalmente, assistimos a Hamlet (de William Shakespeare) no Teatro Popular do Sesi. Como já havia desenvolvido um projeto sobre Shakespeare no ano de 2000, na escola estadual em que trabalhava na época, em 2001 desenvolvi, já na escola municipal, um pequeno projeto sobre o mesmo autor (na biblioteca havia várias adaptações dos títulos shakespeareanos em 
português). Lemos os textos, fizemos debates; mostrei a intertextualidade presente em obras brasileiras, tais como o filme "Auto da Compadecida", em que há referências ao Mercador de Veneza, e a novela "O cravo e a rosa", em que Walcyr Carrasco toma, como ponto de partida, A megera domada.

Em 2003, durante uma visita à exposição de Albert Eckhout, redescobri a Pinacoteca, pois havia estado lá apenas antes da reforma. Tudo estava maravilhoso e propício para levar os alunos.

Como os alunos já conheciam os museus MASP e Oca, comecei o projeto dizendo que, naquele ano, conheceríamos arte brasileira e o melhor seria visitar a Pinacoteca do Estado. A princípio, eles não gostaram da idéia, e vários alunos sugeriram que voltássemos ao Masp, pois o consideravam o museu mais bonito de São Paulo. Como o acervo do Masp é constituído basicamente por arte européia, insisti na idéia de que deveríamos conhecer arte brasileira e aproveitei a oportunidade para falar um pouco da história do prédio da Pinacoteca e do Parque da Luz. Eles acabaram gostando da idéia de conhecer o parque mais antigo da cidade e visitar um prédio construído em estilo neoclássico. Além disso, um aluno trouxe o catálogo da Pinacoteca emprestado de uma escola estadual. Isso me possibilitou preparar a primeira atividade, além de mostrar a todos os alunos o catálogo. As atividades foram: associar imagens do acervo (retrato e auto-retrato, natureza morta e flores, Almeida Júnior e Rubem Valentim) ao nome de alguns quadros; ler o texto "Retrato e auto-retrato", retirado da revista sobre o acervo da Pinacoteca, e responder a algumas questões de "verdadeiro" ou "falso"; explicar a que alguns números retirados do texto "Almeida Júnior" estavam ligados; resumir o texto "Rubem Valentim".

Ocorreu um fato curioso relacionado a esse trabalho. No último dia do curso "Bem vindo professor!", oferecido pela Pinacoteca do Estado, deveríamos apresentar um projeto que tivesse sido desenvolvido ou estivesse em fase de desenvolvimento com o auxílio das aulas desse curso. Como o meu trabalho era o único que já tinha sido finalizado (isso aconteceu com a visita dos alunos ao museu), ele foi muito comentado e folheado, recebendo elogios dos coordenadores do curso. Uma professora de Arte, depois de folhear o meu trabalho, confessou-me que, no concurso daquele ano para o cargo de Professor de Educação Básica especialidade de Arte, havia uma questão sobre o artista plástico Rubem Valentim, e uma das imagens que eu havia usado com os alunos aparecia na pergunta, cuja resposta ela errara. Eu, 
em um gesto de irreverência disse que, se ela tivesse assistido às minhas aulas, certamente teria acertado a questão.

Durante esse período e com os trabalhos realizados, fui percebendo que eu estava formando um grupo de jovens apreciadores de arte. Isso só pôde acontecer por causa da influência recebida durante a participação no grupo de discussão "Sua escola a 2000 por hora". Os alunos estavam usufruindo de uma aprendizagem significativa; os conhecimentos adquiridos nas aulas seriam levados para toda vida. É importante dizer que, enquanto educadora, nunca perdi o foco do meu trabalho e, embora as aulas estivessem voltadas para um componente curricular específico: Arte, os alunos estavam aprendendo Língua Portuguesa, ou seja, lendo e escrevendo melhor, através da arte. Para ilustrar o que acabei de dizer, vale lembrar de um fato que me emociona até hoje e é a razão (talvez principal) do meu trabalho. $\mathrm{Na}$ aula que se seguia à visita a uma Instituição Cultural, eu fazia com que circulasse uma folha onde os alunos escreviam, de forma bem espontânea, suas impressões sobre o evento. Em uma dessas ocasiões, tive oportunidade de ler o seguinte: "Às vezes peço pra minha mãe me levar a um museu e ela sempre responde que não gosta desses lugares, daí eu respondo para ela que eu também não gostava, mas que a senhora me ensinou a gostar".

Gostaria de lembrar ao leitor que a descrição detalhada das atividades realizadas e o comentário de alguns acontecimentos marcantes desse período, servem para ilustrar o conceito de "Educação para o desenvolvimento humano", presente na filosofia do Instituto Ayrton Senna (cf capítulo 1). André e Costa (2004:45) fazem o seguinte comentário: "Na esfera do desenvolvimento humano, a liberdade está expressa no processo de ampliação de oportunidades e opções dadas a esse indivíduo para que ele possa, de fato, desenvolver seus potenciais." O projeto pessoal de aproximação dos alunos com as instituições culturais fez com que os estudantes desenvolvessem seus potenciais, pois as aulas passaram a ser mais dinâmicas e com conteúdos significativos. Os alunos passaram a transformar a si mesmos e assim, tiveram capacidade de exercer uma ação transformadora sobre o mundo. Essa era a intenção da minha aluna ao insistir com a mãe para que ela visitasse um museu.

\section{- Justificativas}

Escolhi estudar um Grupo de Discussão por várias razões: 
- pela relevância social e pedagógica do tema, mostrado por meio da narrativa acima onde destaco a influência positiva recebida por meio da lista, que considero verdadeira universidade on-line. Acredito que todos os profissionais envolvidos nesse projeto atuam melhor e mais eficientemente, sendo mais conscientes da responsabilidade dos três setores no Desenvolvimento Humano de uma nação: governo, empresas e sociedade civil;

- pela relevância científica, pois o estudo do Grupo de Discussão traria acréscimos ao estudo da Análise da Conversação, como elemento comparativo das características das modalidades falada e escrita, em particular da conversação natural e o diálogo eletrônico;

- pelo caráter inédito da pesquisa, sobretudo na montagem e análise das teias. Além de os estudos da CMC, sobretudo no âmbito da Língüística Textual estarem apenas se iniciando.

\section{- Objetivos do trabalho}

O objetivo geral do trabalho é mostrar o funcionamento de um grupo de discussão online denominado: "Lista provisória dos participantes do programa 'Sua escola a 2000 por hora'".

Os objetivos específicos são: discutir o conceito de conversação no fluxo de mensagens de um grupo de discussão; mostrar como essa conversação é possível; mostrar, efetivamente, o que se conversa nesse fluxo de mensagens.

Complementarmente, ficará demonstrada a importância do programa "Sua escola a 2000 por hora" na melhoria da qualidade de ensino em escolas públicas espalhadas pelo país, tendo como exemplo a mudança da minha própria prática pedagógica. A noção de "Educação para o desenvolvimento humano" é fundamental para que essa prática se efetive

\section{- Metodologia empregada}

A metodologia empregada é uma combinação de pesquisa quantitativa e qualitativa. Optei pela pesquisa quantitativa para a formação do corpus, para que se pudesse garantir a precisão dos resultados, evitar distorções de análise e interpretação que poderiam ser causadas ao trabalhar com um corpus diminuto, possibilitando uma margem de segurança quanto às inferências. Dessa forma, ao escolher o mês ideal para o levantamento do subcorpus, optei pelo mês de maior interatividade do grupo, marcado por encontros presenciais (cf item 3, p. 64). 
Tendo estabelecido o subcorpus, passei a uma investigação qualitativa, sobretudo descrevendo o funcionamento das teias, assuntos abordados etc.

Também houve a análise dos dados levantados e discussão teórica do conceito de conversação natural x conversação eletrônica e da coesão como elemento formador do texto. Esses elementos tiveram tratamento adequado mediante pesquisa bibliográfica.

Para que o leitor pudesse entender melhor essa comunidade delimitada, foi descrita a concepção e formação do programa "Sua escola a 2000 por hora", com ênfase na filosofia norteadora do Instituto Ayrton Senna, denominada 'Educação para o desenvolvimento humano"

\section{- Plano da dissertação}

No primeiro capítulo, discorro brevemente sobre a formação do Instituto Ayrton Senna e sobre a noção de "Educação para o desenvolvimento humano", que está presente em todos os seus programas sociais para, em seguida, focalizar o programa "Sua escola a 2000 por hora". O subtítulo "Uma ação transformadora sobre o Brasil" justifica-se por meio do objetivo geral do programa, que é auxiliar a escola pública a modificar a sua atuação, melhorando significativamente a qualidade de ensino. Além disso, reconstituo a história do programa, desde a sua concepção até os dias atuais, com a intenção de mostrar ao leitor a trajetória do grupo.

Depois de mostrar o funcionamento do programa, focalizo, no segundo capítulo, a lista em si (caracterizando o grupo), e faço o primeiro recorte, que é o período estudado. Em seguida detalho a formação do corpus, usando como aparato teórico-metodológico a descrição realizada por McCleary (1996). Ao final do capítulo, dou atenção especial à questão de gênero, pois acredito que as mídias digitais têm contribuído para a formação de um novo gênero.

No terceiro capítulo, concentro o olhar em parte do corpus, que são as teias (conversações coesivas dentro de um fluxo heterogêneo da lista) do mês de agosto ${ }^{6}$ de 2001 .

\footnotetext{
${ }^{5}$ Gostaria de esclarecer o leitor sobre a diferença entre programa e lista. O programa "Sua escola a 2000 por hora" tem como embasamento a filosofia do IAS e uma de suas ferramentas é a lista/grupo "Sua escola a 2000 por hora", ou seja, a lista é parte do programa, não o programa em si.

${ }^{6}$ Lembrando que as teias de agosto são compostas por todas as mensagens de agosto, além de mensagens dos meses de julho, setembro e outubro de 2001. Isso ficará mais claro no capítulo três, pois essas "conversas" eletrônicas não se restringem a um único mês.
} 
No quarto capítulo, discuto a noção de conversação natural em comparação a conversação eletrônica. Comparo, com embasamento teórico de Hilgert (2000) algumas características entre os chats e da lista de discussão escolhida e proponho uma localização em um continuum tipológico.

No quinto capítulo, depois de discutir os conceitos de coesão e coerência, como fatores básicos da textualidade e de me concentrar na coesão, mostro que a atividade aparentemente caótica da lista pode ser entendida por meio dos procedimentos e elementos de coesão presentes nas mensagens. 
"A ética necessária para pôr em prática o Paradigma do Desenvolvimento Humano é a ética da co-responsabilidade. Co-reponsabilidade entre as políticas públicas (primeiro setor), mundo empresarial (segundo setor) e organizações sociais sem fins lucrativos (terceiro setor)."

(ANDRÉ \& COSTA, 2004:27)

\section{EDUCAÇÃO PARA O DESENVOLVIMENTO HUMANO}

\section{1 - O Instituto Ayrton Senna}

O Instituto Ayrton Senna (IAS) foi fundado em novembro de 1994, a partir de uma idéia do piloto Ayrton Senna da Silva, morto em maio do mesmo ano. Ele ficava muito incomodado com a desigualdade social, sobretudo aquela sofrida pelas crianças e jovens. Também acreditava que todo ser humano nasce com potencialidade para ser um vencedor. Se cada criança e jovem tivesse oportunidade de desenvolver esse potencial, poderia ser um campeão em alguma área, assim como ele foi na Fórmula 1.

O Instituto executou projetos inovadores na área da educação já nos primeiros anos de existência, tornando-se exemplo e referência do poder da sociedade civil em contribuir para o avanço da política social.

No ano de 1996, o IAS começou a trabalhar junto com a Organização das Nações Unidas para a Educação, Ciência e Cultura (Unesco). Esse esforço coletivo levou à construção de uma proposta denominada Educação para o Desenvolvimento Humano ${ }^{7}$

Para entendermos melhor esse conceito, devemos conhecer o Relatório da Unesco chamado de Educação: um tesouro a descobrir, organizado por Jacques Delors. Um dos pontos mais importantes desse Relatório é a noção de que a humanidade será capaz de dominar seu próprio desenvolvimento por meio da educação. Para que isso se efetive, toda a sociedade necessita se envolver no processo educativo (DELORS, 1998: 82). Em decorrência dessa proposta, a sociedade civil passou a se organizar e dar forma ao que chamamos de terceiro setor (ANDRE \& COSTA, 2004:8).

\footnotetext{
${ }^{7}$ O Instituto obteve em 2003 o reconhecimento internacional da Unesco, através da chancela de Cátedra Unesco em Educação e Desenvolvimento Humano, título inédito para organizações não-governamentais, pois até então esses títulos eram outorgados a universidades e centros de pesquisa.
} 
Delors (1998: 89-102) também estabelece quatro pilares para a educação para o próximo milênio, que são:

- aprender a conhecer;

- aprender a fazer;

- aprender a viver juntos;

- aprender a ser.

As idéias do economista indiano Amarthya Sen, utilizadas na construção do Paradigma do Desenvolvimento Humano do Programa das Nações Unidas para o desenvolvimento (PNUD) ${ }^{8}$ também foram incorporadas nesse processo. ${ }^{9}$

O IAS acredita que, por meio da educação, os indivíduos terão oportunidades que verdadeiramente transformarão seus potenciais em competências para viver de forma plena. Nessa visão, as pessoas deixam de ser um mero instrumento a serviço do desenvolvimento econômico e passam a ser o centro dos processos de desenvolvimento. Assim, elas se preparam para uma ação transformadora sobre o mundo. "Como num ciclo, ao agirem sobre o mundo e conhecendo-o melhor, as pessoas transformam suas relações consigo mesmas e com os outros". (ANDRE \& COSTA, 2004: 45).

\section{2 - Programas sociais ${ }^{10}$}

O IAS constrói, implementa, sistematiza e avalia tecnologias sociais para serem aplicadas por qualquer organização que, como ele, tenha como foco o desenvolvimento

\footnotetext{
${ }^{8}$ O PNUD é o organismo internacional, ou seja, a entidade das Nações Unidas, que tem por mandato promover o desenvolvimento e eliminar a pobreza no mundo. Entre outras atividades, o PNUD produz relatórios e estudos sobre o desenvolvimento humano sustentável e as condições de vida das populações, bem como executa projetos que contribuam para melhorar essas condições de vida nos 166 países onde possui representação. É conhecido por elaborar o Índice de Desenvolvimento Humano (IDH), bem como por ser o organismo internacional que coordena o trabalho das demais agências, fundos e programas das Nações Unidas - conjuntamente conhecidas como Sistema ONU- nos países onde está presente.

${ }^{9} \mathrm{O}$ autor apresenta uma discussão sobre desenvolvimento que ultrapassa as visões restritas que o apresentam apenas como crescimento do Produto Nacional Bruto, aumento das rendas pessoais, industrialização, avanço tecnológico ou modernização social. Na sua abordagem, a expansão da liberdade é considerada o fim primordial e o principal meio do desenvolvimento.

${ }^{10}$ Para o leitor ter uma noção da grandiosidade do trabalho do Instituto, aqui vão alguns números: 6.545 .794 crianças e jovens atendidos; 343.420 educadores formados; 25 estados atingidos; 146 milhões de reais investidos. Dados de fevereiro de 2007.
} 
humano das novas gerações. Alguns programas estão associados à educação formal e outros à educação complementar. São eles: ${ }^{11}$

- Acelera Brasil (aceleração de aprendizagem de alunos repetentes);

- Se liga (alfabetização de crianças com distorção idade/série);

- Circuito campeão (gerenciamento da aprendizagem nas quatro primeiras séries do Ensino Fundamental);

- Gestão Nota 10 (gerenciamento das escolas e secretarias para melhoria da qualidade do ensino);

- Comunidade conectada (inclusão digital nas comunidades);

- SuperAção Jovem (os jovens protagonizando soluções para a escola e a comunidade);

- Educação pelo Esporte (o esporte promovendo o desenvolvimento de potenciais);

- Educação pela Arte (desenvolvimento de potenciais por meio da arte);

- Brinquedoteca (espaços lúdicos nos hospitais que aumentam adesão ao tratamento).

Subjaz a todos esses projetos a mesma filosofia das quatro aprendizagens sob a perspectiva do desenvolvimento do potencial das pessoas,

Aprender a Ser (ser você mesmo e construir um projeto de vida), Conviver (conviver com as diferenças, cultivando novas formas de participação social), Conhecer (apropriar-se de seus instrumentos de conhecimento e usá-los para o bem comum) e Fazer (atuar produtivamente, facilitando o ingresso e a permanência no novo mundo do trabalho) tornam-se ferramentas de transformação de si mesmo e do mundo (ANDRE \& COSTA, 2004: 46).

1.3 - Uma ação transformadora sobre o Brasil: o programa "Sua escola a 2000 por hora"

\subsubsection{Justificativa do programa}

Nos últimos cinqüenta anos, houve um aperfeiçoamento nas tecnologias de informação e comunicação na sociedade ocidental, de especial significado para a educação.

Hoje já é comum nos grandes centros, como São Paulo, ver escolas, mesmo públicas, com laboratórios de informática, com computadores interligados em rede e conectados à Internet; salas de vídeo com antena parabólica, aparelhos de televisão e vídeo cassete.

${ }^{11}$ Mais informações podem ser obtidas no site do IAS http://www.escola2000.org.br/ e nas publicações do próprio Instituto, que constam nas referências bibliográficas. 
Em vários setores da vida individual e social, há o uso dessas tecnologias de forma cada vez mais corriqueira.

A comunicação interpessoal, nos mais diferentes contextos, faz-se graças ao telefone, ao fax, e principalmente por meio do correio eletrônico. No trabalho, no lazer e nas tarefas do dia-a-dia, a tecnologia é indispensável.

Esse desenvolvimento levou a uma explosão nunca vista na quantidade de informações disponíveis, transformando substantivamente a própria sociedade, que passou a ser designada de Sociedade da Informação.

As novas tecnologias de informação e de comunicação causarão uma transformação na educação, mais em razão das mudanças que produzirão na sociedade, do que por causa de sua introdução e de seu uso nos ambientes intencionalmente dedicados à educação, como a sala de aula.

Num contexto diferente, em que as comunidades eram bastante homogêneas e tipicamente locais, e em que não havia grandes mudanças, ou havia mudanças mais lentas, considerava-se a educação como sendo um processo de transmissão de conhecimentos, valores, e atitudes. Nesse contexto, as pessoas desenvolviam as competências e habilidades, bem como os valores e as atitudes necessários para viver suas vidas, e as informações e os conhecimentos necessários para se conduzir no plano individual e social thes eram transmitidos pela família ou pela escola.

$\mathrm{Na}$ Sociedade da Informação, porém, em que há uma explosão de informações e conhecimentos, em que o acesso à informação e ao conhecimento é fácil e rápido, e em que as competências e as habilidades exigidas para viver vidas autônomas, solidárias e produtivas são complexas e múltiplas, não faz mais sentido continuar a conceber a função da educação da mesma maneira.

Nessa sociedade, a educação deve focalizar sua atenção no chamado "paradigma do desenvolvimento humano", que contempla o desenvolvimento da pessoa, de forma ativa e colaborativa. As competências e habilidades necessárias para conhecer a si próprio e aos seus semelhantes devem estar a serviço da realização pessoal e do bem comum. 


\subsection{2 - Objetivos do programa}

\subsubsection{1 - Objetivo Geral}

O objetivo geral do "Sua Escola a 2000 por hora" é auxiliar a escola pública (Ensino Fundamental II - antigas $5^{\mathrm{a}}$ à $8^{\mathrm{a}}$ séries - e Ensino Médio) a modificar sua atuação, levando em conta a educação como desenvolvimento humano e utilizando ferramentas tecnológicas.

\subsubsection{2 - Objetivos Específicos}

Os objetivos específicos do "Sua Escola" são construir uma tecnologia social, com base na experiência de escolas-parceiras, a fim de que estudantes se capacitem, em larga escala, para viver vidas autônomas, solidárias e produtivas; influir outros sujeitos para que adiram à causa, modificando o papel de professores, alunos e a forma como a escola pública vem sendo gerenciada.

\subsection{3 - Estratégias de desenvolvimento do programa}

Selecionar, por meio de concursos abertos a escolas públicas, escolas que funcionem como parceiras do IAS. Esse trabalho é organizado e coordenado por um grupo de consultores contratados pelo Instituto para garantir a unidade de objetivos e ações do programa. Eles são responsáveis por capacitar e orientar todos os segmentos das escolas parceiras (alunos, professores e direção) no desenvolvimento de seus projetos.

As atividades do programa são avaliadas constantemente para garantir que seus objetivos sejam alcançados com eficiência.

Os projetos devem propor melhorias na qualidade da educação, explorando o uso criativo e inovador da tecnologia, contribuindo para o pleno desenvolvimento dos alunos como pessoas, cidadãos e profissionais; devem ser transdisciplinares; devem desenvolver competências e habilidades, e serem voltados para a solução de problemas reais dos alunos e da comunidade em que vivem, possibilitando a participação ativa e significativa de todos. 


\subsection{4 - Retrospectiva : o início}

No primeiro semestre de 1999, O IAS formou uma parceria com a Microsoft e posteriormente com a Microtec. Estabeleceram que seria feito uma série de concursos anuais $^{12}$, com o objetivo de selecionar e premiar escolas que submetessem os melhores projetos de uso inovador da informática na educação. Inicialmente, apenas com um número restrito de estados, mas com a expectativa de se tornar de âmbito nacional.

\subsection{5. - O site ${ }^{13}$ do projeto: primeiras versões}

A primeira versão do site do Projeto, hospedado, desde o início no endereço http://www.escola2000.org.br, foi lançada concomitantemente com a primeira edição do concurso $^{14}$. Ao longo do segundo semestre de 1999, essa primeira versão foi sofrendo pequenas variações, para informar aos visitantes o andamento do concurso ${ }^{15}$. Na figura abaixo, notem a participação dos estados. Na parte esquerda, o internauta poderia acessar todos os dados do concurso, como regulamento e ficha de inscrição e tomar conhecimento de como redigir o projeto de sua escola.

\footnotetext{
${ }^{12} \mathrm{O}$ número foi originalmente fixado em três, embora só tenha ocorrido a $1^{\mathrm{a}}$ edição em 2000 , em que foram premiadas 20 escolas, e a $2^{\mathrm{a}}$ edição em 2001, em que foram premiadas 36 escolas. Isso ocorreu porque os organizadores do concurso entenderam (ao constatarem as dificuldades que essas escolas encontraram para desenvolverem seus projetos) que seria preferível intensificar a assessoria às escolas premiadas a aumentar o número de escolas parceiras.

${ }^{13}$ É um conjunto de páginas, relacionadas, na internet, que representam um espaço de interação. Um site, eventualmente pode ser uma única página.

${ }^{14}$ Nessa edição, o Concurso "Sua escola a 2000 por hora" recebeu 1103 projetos.

${ }^{15}$ É interessante perceber a menção aos quatro pilares para a educação (cf. p 24)
} 


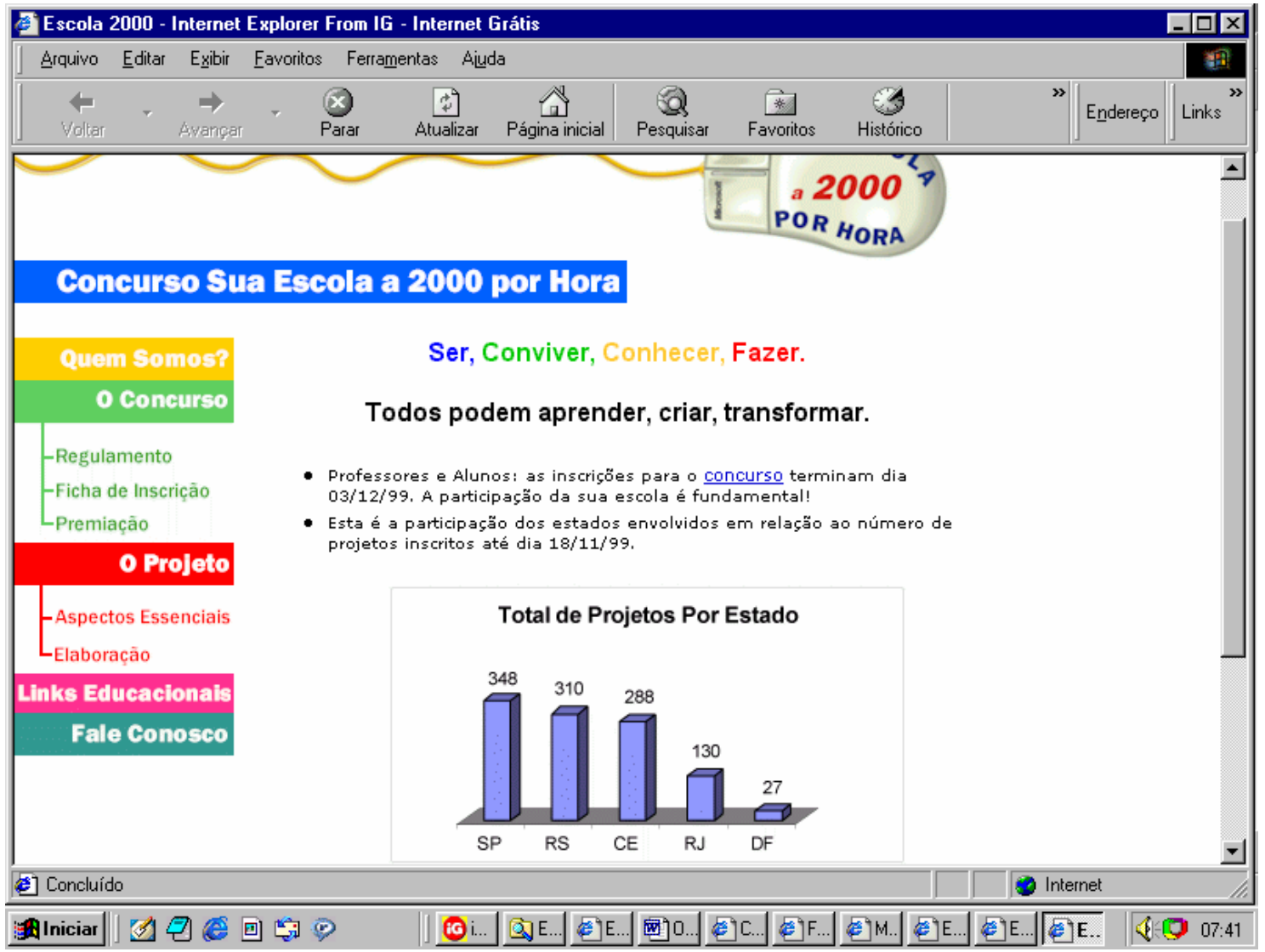

FIGURA 1: Página inicial do site - Versão de 20 de novembro de 1999

A versão seguinte, colocada no ar já no início do ano de 2000, contém o resultado do processo seletivo para a primeira edição do concurso ${ }^{16}$.

\footnotetext{
${ }^{16} \mathrm{Na}$ figura 2 aparecem as informações de quatro das cinco escolas vencedoras. Entre elas está a EE José Lins do Rego, escola em que eu trabalhava na época.
} 


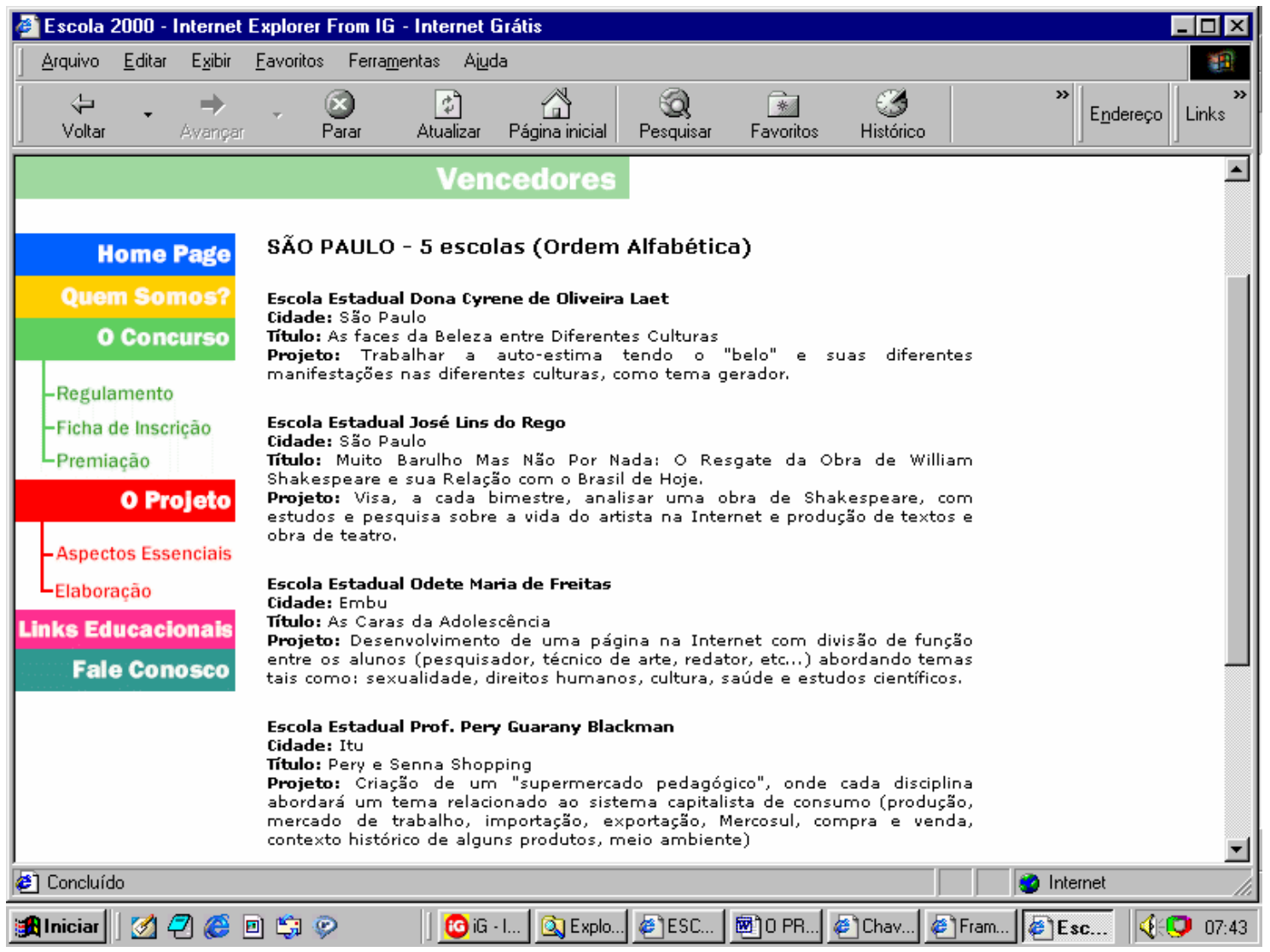

FIGURA2: Versão de 10 de fevereiro de 2000 - Página interna do site com a relação de algumas escolas vencedoras do estado de São Paulo.

\subsubsection{1 - As escolas parceiras ${ }^{17}$}

Para o leitor ter uma noção da diversidade de temas propostos pelas escolas vencedoras, temos:

Meio ambiente - problematização da seca e as várias formas de irrigação; problemas que assolam a comunidade (saneamento básico e moradia precários, controle de natalidade, falta de trabalho, salário baixo e inexistência de sentimentos de respeito pelo outro); estudos sobre a água, seca; e ainda a valorização e conscientização da pesca artesanal.

Arte - estudo da história do Brasil a partir da MPB; estudo da vida e obra do escritor inglês William Shakespeare.

\footnotetext{
${ }^{17}$ As escolas da primeira edição pertenciam aos seguintes municípios: Crato, Fortaleza, Horizonte e Mauriti CE; Embu, Itu, Nova Granada e São Paulo - SP); Campos, Rio de Janeiro e São Pedro D'Aldeia - RJ; Charqueadas, Nova Prata e Porto Alegre - RS; Ceilândia e Sobradinho - DF
} 
Meios de comunicação e tecnologia - construção de um jornal virtual, sites, boletins informativos; visão crítica dos meios de comunicação.

Surdez - projetos para colocar alunos portadores de deficiência auditiva em rede com outros alunos e melhorar a capacitação profissional .

Em vários projetos também aparecia a recuperação da auto-estima dos alunos.

Em março de 2001, foi anunciado o resultado do concurso "Sua escola a 2000 por hora", segunda edição, sendo premiadas trinta e seis escolas. Além do IAS, da Microsoft e da Gateway (que controlava a Microtec), entrou nessa parceria a empresa Tele Centro Oeste Celular.

Para esta edição do concurso, foram distribuídos vinte e cinco mil folders para escolas públicas (praticamente o dobro da edição anterior), com retorno de mil, quinhentos e quarenta projetos ${ }^{18}$. Estes, voltados para a melhoria da qualidade da educação, buscavam novas formas de ensinar e aprender, que envolvessem ativamente os alunos.

Esses projetos passaram por fases sucessivas de avaliação, sendo reduzidos a sessenta e um. Essas escolas foram visitadas pelos membros da Comissão Julgadora do Concurso que, com base no resultado das visitas, selecionou as trinta e seis escolas vencedoras, distribuídas nos seguintes estados/cidades: ${ }^{19}$

Bahia: Salvador (duas escolas), Sobradinho;

Ceará: Fortaleza, Juazeiro do Norte, Meruoca;

Distrito Federal: Brasília, Planaltina, Taguatinga;

Mato Grosso: Cuiabá, Rondonópolis, Várzea Grande;

Minas Gerais: Araxá $^{20}$, Belo Horizonte, Matias Barbosa e Montes Claros;

Paraná: Corbélia, Curitiba e Londrina;

Rio de Janeiro: Rio das Ostras e Rio de Janeiro (duas escolas);

São Paulo: Pirapozinho, Santa Bárbara D’Oeste, São Paulo (duas escolas), São Vicente e Ubatuba;

Rio Grande do Sul: Canela, Novo Hamburgo, Porto Alegre (duas escolas) e Taquara;

Tocantins: Miracema do Tocantins, Miranorte, Paraíso do Tocantins;

\footnotetext{
${ }^{18}$ É interessante perceber que, na segunda edição do concurso, houve um investimento bem maior, pois o Instituto enviou o dobro de kits, entretanto a participação quase não se alterou, pois ficou em $6 \%$. Na primeira edição, a participação ficou em $9 \%$, pois foram enviados aproximadamente 12.500 kits, com retorno de 1.103 projetos.

${ }^{19}$ Acredito ser importante mencionar as localidades para o leitor perceber a abrangência do programa.

${ }^{20}$ Em 2004 o Programa foi adotado como política pública nos municípios de Araxá (MG) e Rio das ostras (RJ) e em 2005 no estado da Paraíba.
} 


\subsection{6 - O Programa na sua versão atual}

Desde 2001, o apoio técnico-pedagógico do IAS tem acontecido principalmente em um ambiente de aprendizagem on-line. Em 2003, o Instituto passou, junto com as escolas parceiras, a centrar seus esforços na sistematização da tecnologia social do Programa "Sua escola a 2000 por hora" e na disseminação desse conhecimento para outras escolas. É a segunda etapa do processo, que inicialmente foi dividida em duas partes: fazer e influir.

Com uma idéia ambiciosa, o IAS propunha, em um primeiro momento, sistematizar conhecimentos que pudessem gerar transformações significativas em crianças e jovens. Entretanto, essa idéia ainda não conseguiria gerar Desenvolvimento Humano em grande escala, pois uma organização não governamental, por maior número de atendimentos que possa garantir, impactará uma pequena parcela de indivíduos de forma direta. Pensando assim, o Instituto criou o Centro de Comunicações pelo Desenvolvimento Humano (CCDU), "que tem por objetivo contribuir para a instalação de uma nova consciência social em relação ao Desenvolvimento Humano de crianças e adolescentes" (ANDRE \& COSTA, 2004: 33). É o eixo do influir.

Essa idéia da influência positiva foi percebida em vários emails enviados ao Grupo de Discussão "Sua escola a 2000 por hora" durante o período da montagem do corpus, como esse fragmento que reproduzo, onde uma integrante da equipe gestora do IAS fala sobre um encontro simultâneo que haverá no município de Rio das Ostras-RJ em 19 e 20 de outubro de 2001 e outro em 19 de outubro de 2001 na cidade de Novo Hamburgo-RS. As escolas parceiras participarão de um chat entre os dois grupos.

A convite do Colégio América Abdalla, de Rio das Ostras (RJ), outras 7 escolas parceiras do Programa Sua Escola a 2000 por Hora reúnem-se para trocar experiências e aprofundar os conhecimentos construídos. Com o apoio da Secretaria Municipal de Educação de Rio das Ostras, outras escolas da rede municipal também serão convidadas a participar do encontro - o objetivo da Secretaria, que acompanha a "revolução" no América Abdalla, é que outras escolas se "contaminem" com as propostas do Programa. Enquanto isso, no mesmo dia 19, outras 5 escolas parceiras estarão se reunindo em Novo Hamburgo (RS), e os organizadores dos dois encontros prepararam um espaço para a troca virtual de experiências: um chat acontecerá às 15h, pelo site do Programa (www.escola2000.org.br). O Programa Sua Escola a 2000 por Hora, fruto da aliança entre o Instituto Ayrton Senna, a Microsoft, a Microtec e a TCO - Centro Oeste Celular, junto com as 56 escolas parceiras, quer contribuir para transformar e melhorar a qualidade da educação por meio do uso inovador e criativo da tecnologia. A maior participação dos alunos nas decisões, o surgimento de novas formas de ensino-aprendizagem e os projetos interdisciplinares são parte da proposta do Sua Escola (www.escola2000.org.br). A realização do evento em Rio das Ostras significa que as escolas tomaram para a si a tarefa de mudar a 
educação, acreditando que podem encontrar seus próprios caminhos e que podem aprender umas com as outras. E o apoio da Secretaria Municipal mostra também que caminhos estão sendo criados para que esse conhecimento construído possa ser compartilhado com outras escolas e que ganhe a força de política pública. As 56 escolas parceiras do Programa estão espalhadas em dez estados brasileiros (TO, CE, BA, DF, MG, RJ, MG, SP, PR e RS) e fazem parte de uma rede de aprendizagem onde são cultivadas experiências replicáveis (tecnologia social) de estratégias que visam a melhoria da qualidade da educação por meio do uso da tecnologia. (M 2090 - Teia $1^{21}$ )

Escolhi esse e-mail também por nele haver toda a filosofia do IAS, a saber: fazer do educando protagonista do seu próprio conhecimento; por meio da tecnologia ser possível melhorar a qualidade da educação pública no país; pedagogia por projetos etc.

Nesse mesmo ano, o Instituto realizou uma parceria com o Canal Futura e produziu uma série com 13 vídeos sobre o programa ${ }^{22}$. Esses vídeos mostram a filosofia do projeto, com imagens e depoimentos das escolas parceiras, e equipe do Instituto Ayrton Senna.

Atualmente o site do Programa "Sua escola a 2000 por hora" permite várias formas de interação para qualquer um que acesse o site. São elas: Grupos de Discussão (três grupos distintos, com os seguintes títulos: 4 pilares, Nova Educação e Educação Ambiental) ${ }^{23}$, Fóruns (atualmente há quatro fóruns, com os seguintes temas: Nova Educação, Gestão, Tecnologia e Navegue Protegido) ${ }^{24}$ e Reuniões virtuais (esses encontros acontecem em forma de chat mais ou menos quinzenais ${ }^{25}$. O site também disponibiliza enquetes ${ }^{26}$.

\footnotetext{
${ }^{21}$ M 2090 significa mensagem 2090. O gerenciamento do software faz isso automaticamente. Teia 1 significa que essa mensagem encontra-se dentro da conversação $n^{\circ} 1$, pois as teias foram numeradas de 1 (teia mais complexa, com maior número de mensagens) até a teia de número 37 (menos complexa, com 5 mensagens) e aparecem todas no anexo 1. A noção de teia é explicada no cap. 3, mas de maneira geral significa um conjunto autônomo de fios discursivos. O conteúdo das mensgens não foi alterado, mesmo quando apresentava erros.

${ }^{22}$ A mensagem 8624, de 25/03/2003, fala sobre esse assunto e informa o título de cada um dos programas: 1Por Dentro do Programa, 2 - Computador e Escola, 3 - Organização da Sala de Informática, 4 - Tecnologia: Comunicação e Aprendizagem, 5 - Competências e Habilidades, 6 - Interdisciplinaridade e Temas Transversais, 7 - Aprendizagem por Projetos, 8 - Meio Ambiente, 9 - Protagonismo Juvenil, 10 - Mídia Jovem, 11 Tecnologia como Ferramenta de Desenvolvimento de Portadores de Necessidades Especiais, 12 - Escola e Comunidade, 13 - Ampliando a Rede.

${ }^{23}$ Esses grupos possuem, respectivamente, as seguintes propostas: discutir a educação na perspectiva dos 4 pilares: Aprender a ser, conhecer, fazer e conviver; discutir habilidades e competências, o uso criativo e inovador da tecnologia, o trabalho por projetos e o protagonismo juvenil; fazer uma abordagem transdisciplinar da educação ambiental em todas as áreas do conhecimento.

${ }^{24}$ Os fóruns possuem os seguintes objetivos: Da escola que temos à escola que queremos; Como gerir a transição para uma nova escola democraticamente; Educação e tecnologia para o desenvolvimento humano; Como orientar os alunos a navegar na Internet de forma segura?

${ }^{25}$ A última reunião virtual ocorreu em 26 de outubro de 2006, com o seguinte tema: Comunidades on-line de aprendizagem.

${ }^{26}$ Enquete atual: Com qual finalidade seus alunos mais utilizam o computador? ( ) Comunicação via e-mail; ( ) Busca de informação; ( ) Disseminação de produção - construção de sites e blogs; ( ) Bate-papo e sites de relacionamento; ( ) Jogos.
} 


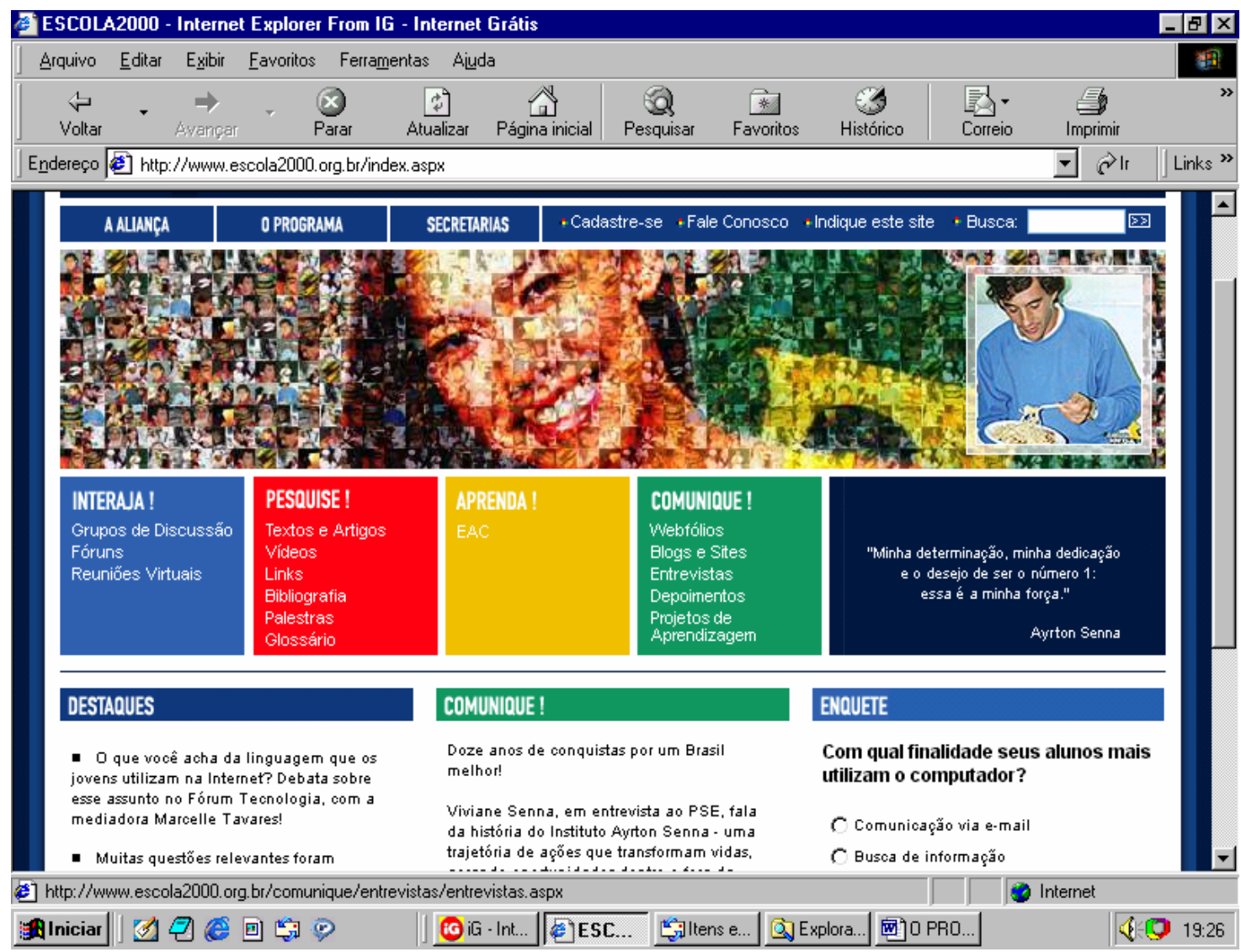

FIGURA 3: Versão atual do site - novembro de 2006

O site também disponibiliza várias formas para que as escolas parceiras divulguem seu trabalho. São elas: webfólios ${ }^{27}$, blogs $^{28}$ e sites, entrevistas, depoimentos e

projetos de aprendizagem ${ }^{29}$.

${ }^{27}$ Versão electrônica de portefólio. Uma vez publicada em uma página da Internet, cria a interatividade. Enquanto ferramenta pedagógica, o web/portefólio é um instrumento de avaliação que proporciona a oportunidade de revelar conhecimentos e capacidades que não são facilmente observáveis através de outros meios de avaliação. Ao construir o seu web/portefólio, o estudante transforma-se num agente efetivo do seu processo de aprendizagem.

${ }^{28}$ Blog é uma abreviação de weblog, que deriva por sua vez de log-book (diário de bordo ou livro de registros). Muitos usam esta ferramenta à disposição na internet para fazer o seu diário eletrônico. O programa pode ser baixado gratuitamente, por diferentes provedores, e permite a interação com qualquer internauta. Entretanto, o blog não serve apenas como diário pessoal. É um ótimo canal, e bem fácil de trabalhar, para relatar projetos (pessoais ou coletivos), inserir textos e fotos. Com ele, se cria o hábito de registro e se divulgam boas iniciativas. É uma ótima estratégia para dar a palavra aos estudantes e desenvolver a sua criatividade.

${ }^{29}$ O Programa "Sua escola a 2000 por hora" tem insistido na tese de que a educação deve ter lugar através da metodologia de projetos de aprendizagem via tecnologia digital. Esses projetos são de escolha do próprio aluno, alicerçados em seus interesses, e, em geral, transdisciplinares. Nessa metodologia é atribuída ao educador a responsabilidade de encontrar maneiras de, a partir desses interesses, tornar a atividade da criança útil no desenvolvimento das competências básicas necessárias para que ela se torne capaz de transformar seus sonhos em realidade. In: CHAVES, Eduardo. Concepção de Aprendizagem e Projetos de Aprendizagem na Visão do 


\title{
1.3.7 - Colhendo os resultados
}

Não só o programa Sua Escola a 2000 por hora, mas todos os projetos desenvolvidos pelo Instituto Ayrton Senna têm mostrado bons resultados. Oliveira (1999) dedica um livro inteiro para explicar o funcionamento de um dos projetos, denominado"Acelera Brasil". Cabe lembrar que esses projetos se entrecruzam, pois a noção de Educação para o desenvolvimento humano está presente em todas elas.

Para encerrar esse capítulo, gostaria de mostrar alguns exemplos, por meio de depoimentos do impacto que esses projetos vêm causando na vida de muitas pessoas.

\begin{abstract}
Antes eu não sabia de nada, porque as professoras não tinham interesse de ensinar, e hoje estou feliz, me sinto um herói, pois aprendi a consultar o dicionário, fazer maquete, planta geográfica, que temos direito e deveres, a me valorizar e valorizar a minha família. Depoimento de Jussaro Damasceno Pereira, aluno de aceleração em Eunópolis, BA (OLIVEIRA, 1999:129).
\end{abstract}

O município de Rio das Ostras/RJ adotou o programa do IAS como política pública. Os bons resultados aparecem nessa mensagem:

De: SEMED - J. C. T. M.

Enviada em: Ter, 06 Jun 2006 10:45:03

Assunto: Res: [esc2k] Rio das Ostras no IAS

Amigos,

Esse foi o resultado do encontro em São Paulo...

Rio das Ostras é destaque do programa do Instituto Ayrton Senna O município é case de sucesso do Programa Sua Escola a 2000 por Hora

O prefeito de Rio das Ostras, Carlos Augusto, aproveitou a estada em São Paulo para participar do Salão do Turismo, para se reunir nesta segunda-feira, dia 5, com a diretora executiva do Instituto Ayrton Senna, Margareth Goldenberg, e com a gerente do Programa Sua Escola a 2000 por Hora, Kátia Ramos, na sede da instituição, para fazer uma análise dos resultados do processo de implantação do programa no município.

Também estiveram na reunião as secretárias de Educação da Prefeitura de Rio das Ostras, Maria Lina Paixão, e de Bem-Estar Social, Márcia Almeida, a subsecretária de Educação, Rosângela Duarte, a diretora da Casa da Educação, Edilane Carvalho, e a assistente pedagógica da Casa da Educação, Márcia Alves.

Programa "Sua Escola a 2000 por Hora". http://www.escola2000.org.br/pesquise/texto/textos art.aspx?id=74 . Acesso: 30/03/07. 
Segundo a gerente do Programa, Kátia Ramos, a reunião teve o objetivo de analisar a prática pedagógica e os resultados, além de traçar metas para a consolidação do programa na rede municipal de educação.

Hoje, o Programa Sua Escola a 2000 por Hora funciona em nove escolas de Rio das Ostras, envolvendo 24 professores, cinco coordenadores e nove diretores da Secretaria de Educação, atendendo 629 alunos. A expectativa da gerência do programa e também do grupo gestor formado por profissionais de Rio das Ostras é dobrar a quantidade de professores parceiros e aumentar para 1.680 alunos atendidos. Para isso, o programa precisa passar por alguns ajustes como melhorar a manutenção nos equipamentos dos laboratórios, aumentar o acervo das bibliotecas nas escolas e facilitar a comunicação interna entre a Prefeitura e o Instituto Ayrton Senna.

O prefeito Carlos Augusto e a secretária de Educação ficaram satisfeitos com a avaliação feita pelo Instituto Ayrton Senna do programa no município. Segundo a diretora Margareth Goldenberg, a implantação do Programa em Rio das Ostras é destaque nacional. "Temos Rio das Ostras como nosso showroom.

Precisamos mostrar que o programa está dando certo e Rio das Ostras é nossa vitrine", disse.Rio das Ostras participa desde 2001 do Programa Sua Escola a 2000 por Hora, mas foi em 2005 que o município adotou o programa como política pública de Educação. O Instituto Ayrton Senna dá apoio pedagógico e acompanha todo processo, que atende alunos da $5^{\mathrm{a}}$ a $8^{\mathrm{a}}$ séries do Ensino Fundamental e do Ensino Médio.

J. C.

Gestão de Tecnologias Educacionais

Secretaria de Educação

Rio das Ostras-RJ

(grifos meus)

Destaco também, dois assinantes, uma aluna e um professor. A aluna J.R.P., cuja participação levou-a a se tornar Agente Técnica Júnior do IAS. Sua participação consta no capítulo 3, ítem 5 p 81-83; O professor, MRC, inicia sua participação como Professor na Escola Normal de Taquatinga/DF, que atende alunos surdos, como Coordenador de Informática. Ele, que também é surdo, durante o período de participação na lista graduou-se em Pedagogia; passou a ocupar o cargo de diretor regional da Feneis (Federação Nacional de Educação e Integração dos Surdos) no DF; e atualmente faz um segundo curso universitário, promovido pela UFSC, a graduação no curso de Letras/Libras. Reproduzo três mensagens:

From: $<$ m.r.cr $>$

To: "Lista Geral" <esc2k@yahoogrupos.com.br>; "grupo pse" <educamb@yahoogrupos.com.br>

Sent: Tuesday, August 22, 2006 12:37 AM

Subject: [esc2k] Notícia!!! Novo Diretor Regional de FENEIS

Olá pessoal,

Notícia! 
Agradeço com primeiro vez de novo Diretor Regional de Federação Nacional de Educação e Integração dos Surdos - FENEIS/DF - M, já posse ser emoção e maravilhoso. Que passando 6 candidatos, escolher de me um ganhou... Foi domingo com posse, que surdos, irmã de namorado, tia e prima, associação visitam posse sobre importância será rumo no projeto de FENEIS. To felicidade para L. visita na posse, estou emoção e maravilhoso, que convite dela apresenta nos ser vida de mim. Agradeço para você e sua amiga de L., que ver alegria com amor... Que lembro saudade para COPISURDOS, que valor com vida, ser emoção agradeço para Sua Escola a 2000 por Hora é unico importância ser caminho com melhor tecnologia.

Sempre sonho muito valor com FENEIS possível crescimento, que ajudar para surdos, que desafio com desenvovler com cultura para identidade para surdos ser capaz ser vida com influência com para inclusão social, ser aprender respeito com comunicação ser também ser tecnologia com desenvolver como comunicação ser inclusão social....

Ate breve, que criar site de FENEIS, quando em setembro vão mostrar as galeiras de posse.

Obrigado! SUA ESCOLA A 2000 POR HORA.... TE AMO PARECEIRAS DE ESCOLAS....

Abraço, M.

Diretor Regional de FENEIS/DF

Assistente Administrativo Emprego Especial

From: $<$ m.r.c $>$

To:<educ-amb@yahoogrupos.com.br>;"ListaGeral" <esc2k@yahoogrupos.com.br> Sent: Wednesday, September 13, 2006 12:19 PM

Subject: [esc2k] Convite de Formatura Pedagogia

Olá Família de Programa Sua Escola a 2000 por Hora,

Novidade! Hoje, eu estou ansioso e alegria, mas vou formatura a noite. Eu sei, mas estados longe, mas sem problema. Eu agradeço para parceiros, que especial ser orgulhoso para nos... To felicidade, sempre lado com junto com vocês... Te amo por nossa família de PSE...

Convite!!!

Colação de Grau

13 de Setembro de 2006, às $20 \mathrm{~h}$

Auditório da FAJESU

QNG 46, A.E

Taguatinga Norte

Pedi atrasado, mas não tempo, muito trabalho corrido... louco. risoooooo... pois atrsado mandar para vocês... Depois eu prepara página de site formando.... Valeu. mais lindo. Ok.

Agradeço para PSE e Parceiros....

Abraço, M.

Diretor Regional da FENEIS/DF

Comissão de Coordenadoria de Inclusão e Cidadaina. 
Mensagem original ----

De: "m.r.c."

Para: Lista Geral ; grupo pse

Enviadas: Quarta-feira, 20 de Setembro de 2006 1:05:25

Assunto: [esc2k] ALEGRIA FORMATURA

Olá pessoal,

Agradecimento maior especial para Programa Sua Escola a 2000 por Hora e parceiros de escolas, que estamos muito felicidades, sensibilidade com orgulhoso nossa família de Programa Sua Escola a 2000 por Hora.

Emoção, que eu fui formatura mais belíssimo que coração bastante e estou felizes ser aprender como tecnologia, influir, desafio e demais. Eu já homanagem para Sua Escola a 2000 por hora e Professoras interpretes e desafio com mudança vida ser sucesso e merece sempre consegui vence minha vida. Agradeço para PSE e Professores... também alunos..... todos valeu amigos....

Maravilhoso já tirou fotos demais sobre Missa em Ação de Graças, colação de Grau e Baile de Gala são maravilhoso, estou lárgimas e sempre amor todos.. Vou fazer lindo, mas proximo final de mês, através será outubro. ate breve de novo site.... também feneis de site...

Eu vou viajar para Belém em cidade São Luiz, que segunda-feira ate domingo, onde Centro de Apoio às Pessoas com Surdez - CAS, então eu palestrante, oficinas e Comissão que sobre IV Seminário do CAS.

Mando grande abraço, Messias

Diretor Regional da FENEIS

Comissão de Coordendoria de Inclusão e Cidadania - SENAC

Estudante de curso Letras Libras - USFC - Polo : UNB - Univerdade de Brasília

Pesquisador - UNB

Pós Graduação em LIBRAS de Coordenador Apoio Pedagógico

(grifos meus)

Nas três mensagens acima, percebe-se o quanto o Programa sua escola a 2000 por hora é importante na vida dele. Embora hoje ele não trabalhe mais em uma escola parceira, o vínculo continua, o que é demonstrado ao referir-se aos parceiros como sendo "sua família". No primeiro e-mail é mencionado L. integrante da Equipe Gestora do IAS. 


\title{
2. MONTAGEM DO CORPUS
}

\section{1 - Escolha e preparação do corpus $^{30}$}

Nesse capítulo, descrevo a origem e as configurações gerais do corpus: quantidade de mensagens, sua tipologia etc. É dada atenção especial à questão dos gêneros digitais.

Por meio dessa lista, trocávamos informações com as outras dezenove escolas participantes e a equipe gestora do Instituto Ayrton Senna, cujos membros visitavam cada uma das escolas em intervalos de aproximadamente quinze dias.

Durante o ano de 2000, tive uma participação mais ativa na lista. A partir de 2001, continuei como assinante da lista, porém, como me exonerei da Rede Estadual de Ensino, passei a apenas ler as mensagens enviadas para o grupo.

\section{2 - O grupo: "Lista Provisória dos Participantes no Projeto "Sua escola a 2000 por hora".}

Esse grupo se caracteriza por trocar informações sobre como usar o computador como recurso real de melhoria da aprendizagem, conforme podemos perceber nesses dois exemplos do início da lista:

\author{
"[escola2000] Mensagem inicial \\ From: A B P \\ Date: Tue, 21 Mar 2000 18:23:26
}

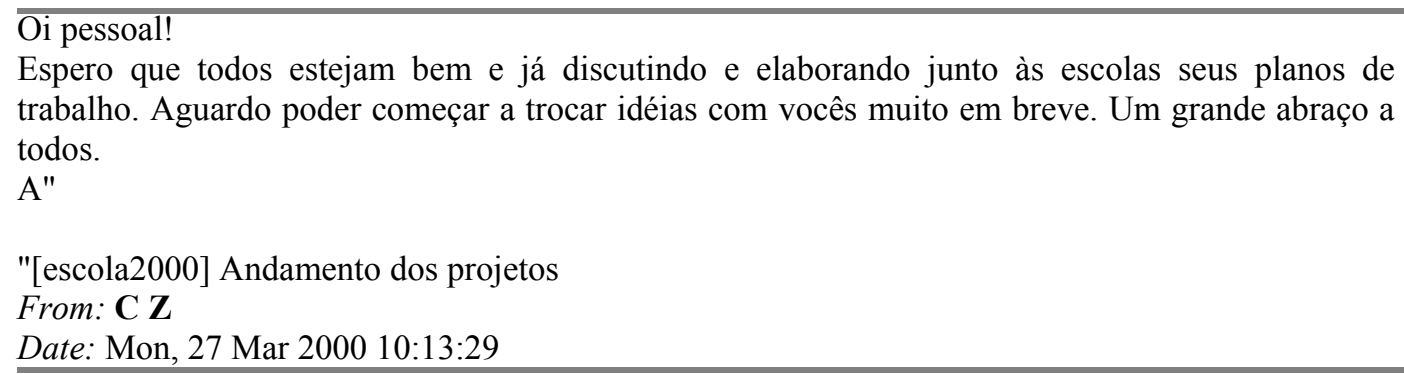

Foi realmente incrível ter passado 5 dias com vocês aqui em São Paulo. Já temos as fotografias e pudemos avaliar o que deu certo e o que podemos melhorar para as próximas vezes. As avaliações escritas e apresentadas, foram fundamentais para isso. Para nós, do Instituto Ayrton Senna, são esses momentos que realmente dão sentido ao nosso trabalho. O que interessa é ver os olhos brilhando de quem também apostou nesse Concurso, para que os projetos dêem o mais certo possível. Por isso foi tão importante. Obrigada!

Agora que já nos acalmamos (e descansamos!!) e sabendo que todas as escolas estão trabalhando a todo vapor, será que vocês poderiam colocar na lista breves relatos de como estão os trabalhos aí nas escolas? Foi implantada alguma idéia que nasceu durante a Semana de Imersão, ou que já estava na cabeça de vocês antes mesmo dela acontecer? E como vocês estão sentindo tudo isso?

\footnotetext{
${ }^{30}$ Referencial teórico-metodológico de McCleary (1996).
} 
Os alunos também se motivaram pelo fato de serem vencedores? Como eles estão reagindo nos projetos? Houve alguma mudança? Não houve?

Vale lembrar que esta lista é um espaço para que possamos trocar informações. Sem dúvida que todos os textos são bem-vindos mas as experiências de vocês também o são. E muito. Quando vcs sentirem o coração bater mais forte porque uma ação deu certo (ou que dará certo, ou mesmo que não saiu do jeito esperado - porque não?) dentro da escola, não esqueçam de nos contar e contar a todos os colegas, já que esse é um dos grandes objetivos do Concurso, a formação de uma rede de idéias inovadoras. Pode ser?

Temos certeza de que há muito o que conversar a esse respeito.

Um grande abraço para todos e muito sucesso.

C.

A lista Esc 2k $\mathbf{k}^{31}$ ainda não tinha uma "personalidade" formada e começou com poucos integrantes: 45 assinantes. A maioria dos professores nunca tinha participado de uma lista de discussão. Além disso, o ano de 2000 caracterizou-se por um período de pouco movimento. Muitas escolas, como aquela em que eu trabalhava, passaram o ano inteiro aguardando a instalação da internet. Esse acontecimento teve conseqüências negativas, pois algumas escolas não puderam participar da lista pela falta de acesso. Na escola em que eu trabalhava, só eu participava da lista (de casa e por acesso discado). Tentei ainda alguns contatos telefônicos com duas escolas daqui de São Paulo (a de Sapopemba e a do Embu), a fim de trocar experiências, mas sem sucesso.

Alguns membros mantinham relações pessoais, pois trabalhavam na mesma escola. Entretanto, a maioria não participava de eventos em outras modalidades. Muitos membros não possuíam sequer computador e, por isso, a maioria não conhecia outras modalidades de comunicação mediada por computador.

\section{3 - Caracterização da lista}

Um Grupo de Discussão é um conjunto hierarquicamente organizado para internautas interessados em um assunto específico. As discussões dentro desse grupo acontecem por intermédio de mensagens eletrônicas (e-mails) enviadas pelos participantes e listadas no site provedor.

\footnotetext{
${ }^{31}$ Passarei a usar este nome, pois essa é a maneira como a "Lista Provisória dos Participantes no Projeto 'Sua escola a 2000 por hora" é comumente chamada.
} 
Todos os assinantes ${ }^{32}$ da lista recebem as mensagens encaminhadas ao endereço do grupo pelos seus membros. Para que um novo internauta faça parte do grupo, ele envia uma mensagem ao administrador ${ }^{33}$ da lista solicitando sua inclusão no grupo. Da mesma maneira, ao querer desligar-se do grupo, ele envia uma outra mensagem, pedindo para que seu nome seja excluído da lista de assinantes.

Os grupos de discussão possuem regras próprias. Há os não moderados, ou seja, toda mensagem enviada ao grupo é distribuída aos assinantes, na forma que foi enviada; nos moderados, o administrador do grupo recebe as mensagens antes dos demais e faz uma triagem, eliminando mensagens inconvenientes ou editando partes delas, numa espécie de "censura"; nos moderados "de leve", o administrador impede a distribuição de mensagens que nada tenham a acrescentar à discussão, como, por exemplo, mensagens em que os usuários apenas endossem o que um outro escreveu.

Não há um consenso na denominação "grupo de discussão". Esses grupos também são chamados de listas de discussão (Marcuschi, 2004: 29 e 59), pois todos os assinantes estão cadastrados em uma lista.

A lista Esc 2k é fechada, moderada "de leve", e a associação é feita por convite. Ela também não permite anexos, por isso muitos assinantes copiam e colam mensagens vindas de outros lugares: sites, outras listas, reportagens etc.

\section{4 - O período}

As mensagens da lista, desde sua criação em 20 de março, foram hospedadas no site: http://www.escribe.com/education/escola2000/index.html. A partir de 14 de abril de 2001, as mensagens passaram a ser hospedadas por outro provedor no site: http://br.groups.yahoo.com/group/esc2k/ , com a seguinte descrição:

Lista de Discussão geral de todos os segmentos (alunos, professores e diretores das escolas parceiras, orientadores, consultores e a coordenação) do Programa "Sua escola a 2000 por hora" do Instituto Ayrton Senna e da Microsoft. Essa lista possui atualmente 824 associados.

\footnotetext{
${ }^{32}$ Optei por usar os termos "membro" e "assinante" como sinônimos, pois, no caso da lista Esc 2K, todos os membros são assinantes. McCleary, porém, explica que "membro" é mais abrangente do que "assinante", pois há listas em que leitores regulares não são assinantes, mas são considerados membros. (1996: 46)

${ }^{33}$ Vários são os termos usados para se referir a quem coordena uma lista de discussão: list owner, manager, administrator, moderator, coordinator (McCLEARY, 1996:46).
} 
Estabeleci, então, como corpus de pesquisa, todo o volume de correspondência da Esc 2k coletado entre 14 de abril de 2001 a 30 de abril de 2002, ou seja, um ano completo, além das 26 mensagens iniciais no novo site. Esse período mostrou-se mais interessante porque o grupo possuia mais assinantes por causa da elaboração da segunda edição do concurso, além de as escolas da primeira edição já estarem com a internet instalada ${ }^{34}$; alguns assinantes já tinham mais experiência, o que aumentou a interatividade da lista.

As correspondências foram gravadas no site do grupo. Cada correspondência recebia automaticamente um número. A tabela abaixo mostra o número de correspondências por mês.

\begin{tabular}{|l|r|}
\hline Mês & $\mathbf{N}^{\mathbf{0}}$ de correspondências \\
\hline abril de 2001 & 26 \\
\hline maio & 307 \\
\hline junho & 207 \\
\hline julho & 225 \\
\hline agosto & 760 \\
\hline setembro & 393 \\
\hline outubro & 433 \\
\hline novembro & 385 \\
\hline dezembro & 231 \\
\hline janeiro 2002 & 84 \\
\hline fevereiro & 207 \\
\hline março & 485 \\
\hline abril & 517 \\
\hline Total & $\mathbf{4 2 6 0}$ \\
\hline
\end{tabular}

\section{5 - Tratamento do corpus}

As mensagens do período estabelecido foram copiadas uma a uma do site http://br.groups.yahoo.com/group/esc2k/ e transportadas para um arquivo de formato texto. Foi utilizado o software da Microsoft Word 2000 para gravá-las.

Primeiramente as mensagens foram transportadas sem formatação; em seguida, foi criada uma macro ${ }^{35}$ no Word para formatar estas mensagens, separando o cabeçalho da

\footnotetext{
${ }^{34}$ Os computadores (parte do prêmio do concurso) foram entregues rapidamente. Entretanto, por diversas razões a internet demorou a ser instalada, prejudicando a participação das escolas. No caso da escola em que trabalhava na época, eu era a única participante, e acessava as mensagens do grupo de casa e por linha discada.

${ }^{35}$ Uma macro é uma seqüência de comandos e instruções do Word que são agrupados como um único comando para executar uma tarefa automaticamente. Em vez de executar manualmente uma série de ações demoradas e repetitivas no Word, o usuário cria um comando personalizado que a executa para ele.
} 
mensagem para melhorar a visualização e facilitar a compreensão do texto. Por causa do grande número de páginas, para cada mês foram criados e salvos três arquivos separados (os títulos dos arquivos foram estabelecidos da seguinte maneira: maio_2001_1, maio_2001_2, maio_2001_3, abril_2001_1... até abril_2002_3) , contendo em média 150 páginas cada arquivo, totalizando aproximadamente 5.400 páginas. A tabela abaixo ilustra melhor o que foi dito:

\begin{tabular}{|c|c|c|c|c|c|}
\hline $\begin{array}{l}\mathrm{N}^{\mathrm{o}} \mathrm{de} \\
\text { ordem }\end{array}$ & Mês & Ano & $\begin{array}{l}\text { Código do } \\
\text { documento }\end{array}$ & $\begin{array}{l}\text { Mensagem } \\
\text { inicial }\end{array}$ & $\begin{array}{l}\text { Mensagem } \\
\text { final }\end{array}$ \\
\hline 1 & Abril & 2001 & 1 & 1 & 26 \\
\hline 2 & Maio & 2001 & 1 & 27 & 131 \\
\hline 3 & Maio & 2001 & 2 & 132 & 218 \\
\hline 4 & Maio & 2001 & 3 & 219 & 333 \\
\hline 5 & Junho & 2001 & 1 & 334 & 388 \\
\hline 6 & Junho & 2001 & 2 & 389 & 463 \\
\hline 7 & Junho & 2001 & 3 & 464 & 540 \\
\hline 8 & \begin{tabular}{|l|} 
Julho \\
\end{tabular} & 2001 & 1 & 541 & 616 \\
\hline 9 & Julho & 2001 & 2 & 617 & 728 \\
\hline 10 & Julho & 2001 & 3 & 729 & 765 \\
\hline 11 & Agosto & 2001 & 1 & 766 & 1055 \\
\hline 12 & Agosto & 2001 & 2 & 1056 & 1280 \\
\hline 13 & Agosto & 2001 & 3 & 1281 & 1525 \\
\hline 14 & Setembro & 2001 & 1 & 1526 & 1655 \\
\hline 15 & Setembro & 2001 & 2 & 1656 & 1802 \\
\hline 16 & Setembro & 2001 & 3 & 1803 & 1918 \\
\hline 17 & \begin{tabular}{|l|} 
Outubro \\
\end{tabular} & 2001 & 1 & 1919 & 2038 \\
\hline 18 & Outubro & 2001 & 2 & 2039 & 2183 \\
\hline 19 & Outubro & 2001 & 3 & 2184 & 2351 \\
\hline 20 & Novembro & 2001 & 1 & 2352 & 2507 \\
\hline 21 & Novembro & 2001 & 2 & 2508 & 2583 \\
\hline 22 & Novembro & 2001 & 3 & 2584 & 2736 \\
\hline 23 & Dezembro & 2001 & 1 & 2737 & 2860 \\
\hline 24 & Dezembro & 2001 & 2 & 2861 & 2942 \\
\hline 25 & Dezembro & 2001 & 3 & 2943 & 2967 \\
\hline 26 & \begin{tabular}{|l|} 
Janeiro \\
\end{tabular} & 2002 & 1 & 2968 & 3051 \\
\hline 27 & Fevereiro & 2002 & 1 & 3052 & 3113 \\
\hline 28 & Fevereiro & 2002 & 2 & 3114 & 3189 \\
\hline 29 & Fevereiro & 2002 & 3 & 3190 & 3258 \\
\hline 30 & Março & 2002 & 1 & 3259 & 3391 \\
\hline 31 & Março & 2002 & 2 & 3392 & 3578 \\
\hline 32 & Março & 2002 & 3 & 3579 & 3743 \\
\hline 33 & Abril & 2002 & 1 & 3744 & 3904 \\
\hline 34 & Abril & 2002 & 2 & 3905 & 4084 \\
\hline 35 & Abril & 2002 & 3 & 4085 & 4260 \\
\hline
\end{tabular}




\section{6 - Formato das correspondências}

Para que o leitor tenha idéia de como as mensagens aparecem no site, coloco como exemplo uma correspondência inteira e, em seguida, descrevo cada uma de suas partes (lembrando que mantive sempre a integridade de todas as mensagens citadas no corpo do trabalho, mesmo quando elas apresentavam erros de ortografia ou digitação):

CABEÇALHO:

MENSAGEM:
De: "n"

Data: Qui, 16 de Ago de 2001 7:13 pm

Assunto: Re: [esc2k] Barreiro - Araxá

Oi pessoal!

O Ny me pediu para contar um pouco da história do Barreiro. É um dos pontos turísticos de nossa cidade, onde fica o balneário, as águas medicinais e a lama medicinal. Já ouviram falar de D. Beja? Dizem que era lá que a "dama" se banhava! No mesmo local fica o Grande Hotel, construído entre os anos de 1938 à 1944, quando foi inaugurado com a presença do presidente Getúlio Vargas.

Assim na década de 40 Araxá se transformou em pólo turístico regional e nacional, com a inauguração do complexo turístico - Grande Hotel e Balneário, que ainda hoje figura como um dos mais belos projetos arquitetônicos do Brasil.

O hotel esteve fechado por alguns anos e nesse final de semana será entregue as obras de restauração. Vale a pena conferir! Quem ainda se interessar em algo mais da história de Araxá, entre no site www.araxaonline.com.br Espero que eu tenha me saido bem nas informações turísticas! O que acha N? Aprovada? :)

Quando precisarem de um guia... Podem contar comigo! :)

Até a próxima!

ASSINATURA: $\quad$ C - Araxá

CITAÇÃO ANTERIOR: > C,

$>$ O Grande Hotel do Barreiro tem uma longa história de tradições para contar.

$>$ Nós, mineiros, sabemos bem o que ele representa para vocês, araxaenses. Que

$>$ tal vocês contarem um pouco sobre isso? Onde fica, desde quando existe, $o$

$>$ processo (polêmico!!!) das obras... O pessoal de todo

o Brasil está curioso!!!

$>$

$>$ Um abraço,

$>\mathrm{N} \mathrm{M}$

$>$ Orientador - MG

$>\mathrm{n} @ \ldots$

$>$ At 22:45 15/08/01 -0300, you wrote:

$>>$ Olá pessoal!

$>>$ Minha cidade esta semana está um furor! Nos dias 17 e 
$>>$ vai ser reinaugurado o Grande Hotel do Barreiro. Os

$>>$ preparativos estão a 2000 por hora! Hoje fui no local,

$>>$ gente, colocaram tochas por toda a parte e estão

$>>$ embalando a entrada principal do hotel. Na sexta tem

$>>$ show com o cantor Daniel (entrada franca) na entrada do

$>>$ local. No sábado além de várias atividades culturais,

$>>$ vai ter futebol beneficiente com o time do cantor contra

$>>0$ time do hotel (formado por vereadores e autoridades, $>>$ inclusive o prefeito) de manhã no estádio da cidade.

$\mathrm{Na}$

$>>$ parte da tarde vai ter um jogo de vôlei com o time do $>>$ minas tênis contra o time de Uberlândia (entrada, um

$\mathrm{Kg}$

$>>$ de alimente não perecível). Gente, tá $d+$ ! Venham

$>>$ conferir! Vale a pena! Ainda dá tempo!

$>>$

$>>$ Abraços!

$>>$

$>>$ C - Araxá

PROPAGANDA

DO PROVEDOR:

MENSAGEM

DO GRUPO:
$>>$ BOL. O melhor acesso pelo menor preço.

$>>$ Só R\$ 9,90 nos 6 primeiros meses. Menos que a metade

da América!

$>>$ Assine já ! http://www.bol.com.br/acessobol/

$>>$

$>>$

$>>$

$>$

$>>==>$ Para cancelar sua assinatura deste grupo,

$>>$ envie um e-mail em branco para:

$>>$ esc2k-unsubscribe@yahoogroups.com

$>>$

$>>==>$ Para ler facilmente todas as mensagens deste grupo,

$>>$ visite:

$>>$ http://www.escribe.com/education/escola2000/index.html

$>$

$>=$

$>>$

$>>$ Seu uso do Yahoo! Groups é sujeito às regras

descritas em:

$>>$ http://docs.yahoo.com/info/terms/

$>>$

$>$

$>$

$>==>$ Para cancelar sua assinatura deste grupo,

$>$ envie um e-mail em branco para:

$>$ esc2k-unsubscribe@yahoogroups.com 


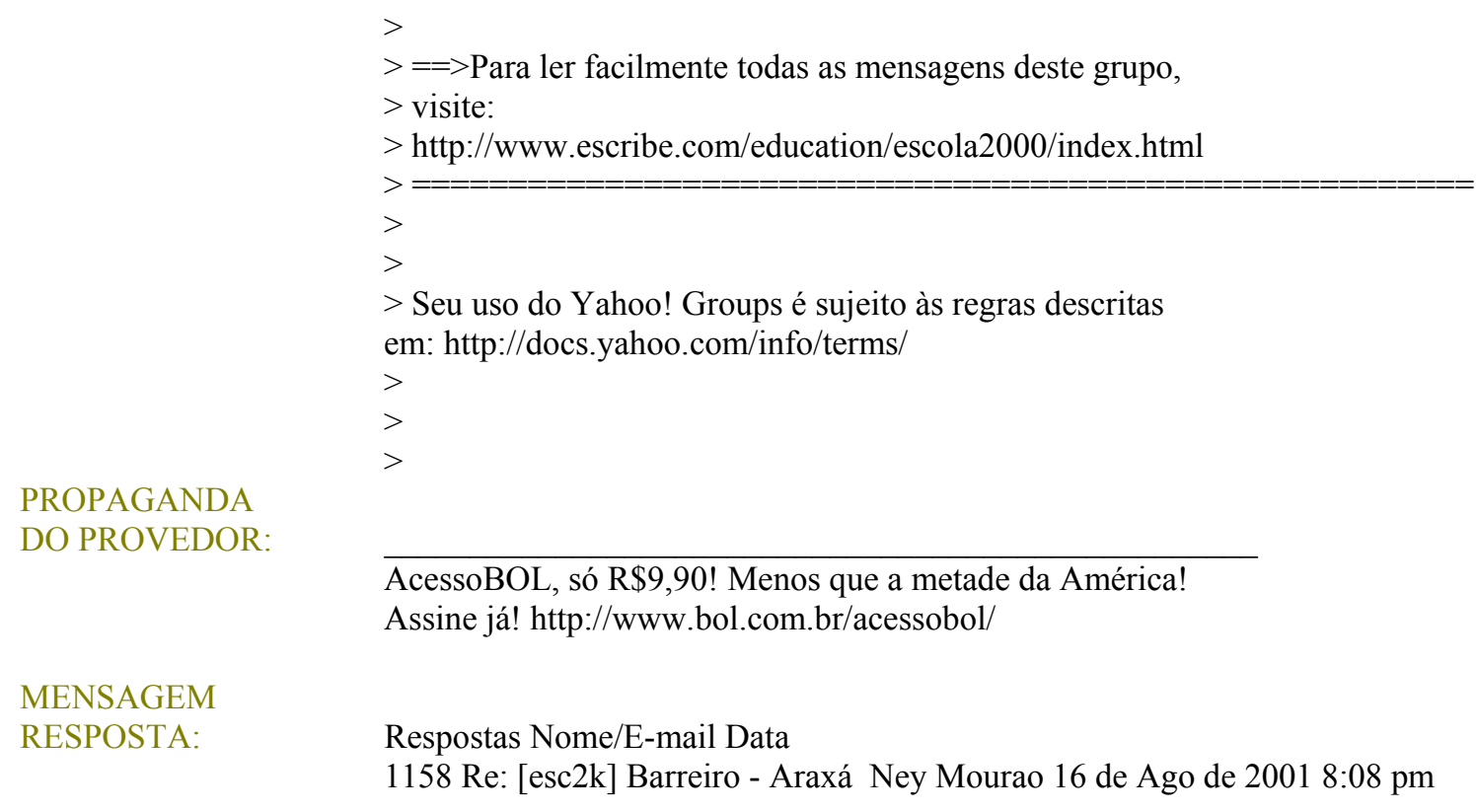

FIGURA 4 - Exemplo de correspondência inteira

Passo agora a descrever o formato de uma correspondência de correio eletrônico veiculado por uma lista. Uma parte dela é determinada pelo próprio programa utilizado; outra é determinada pelas convenções sociais que emergem na maioria das comunidades para facilitar a comunicação em lista. (McCLEARY, 1996:51).

\subsection{1 - O cabeçalho}

Uma correspondência possui duas partes: o cabeçalho e o corpo. No cabeçalho, encontram-se informações necessárias para que o programa de gerenciamento de correspondência possa entregar as correspondências corretamente. Essas informações são úteis para que o usuário saiba qual a procedência da mensagem e possa enviar uma resposta.

Um cabeçalho necessita ter, no mínimo, informações como: nome do remetente (De); data e hora de envio do ponto de origem da mensagem (Data); e rótulo de assunto (Assunto). Na lista Esc 2k não aparece o nome do destinatário (Para), por uma razão simples: é uma lista fechada e todas as correspondências vão para o mesmo endereço, que não é visível no site onde as mensagens são hospedadas. Mas quando as correspondências chegam à minha caixa postal, aparece esse endereço: esc2k@yahoogrupos.com.br . 
Coloco a figura 5 para que o leitor tenha uma idéia do funcionamento de uma lista de discussão.

Essa é a imagem da janela de trabalho (espécie de caixa de correio eletrônica) do programa Outlook Express. ${ }^{36}$ Nela, personalizei a estrutura de pastas, deixando uma pasta exclusiva para receber as mensagens da lista Esc 2k, cujas mensagens aparecem listadas e na seguinte ordem: nome do emissor, assunto da mensagem e data de recebimento e horário. É importante que o leitor perceba que as mensagens listadas estão ordenadas por horário de chegada e não de assunto, e provavelmente pertencem a "conversas" ${ }^{37}$ diferentes.

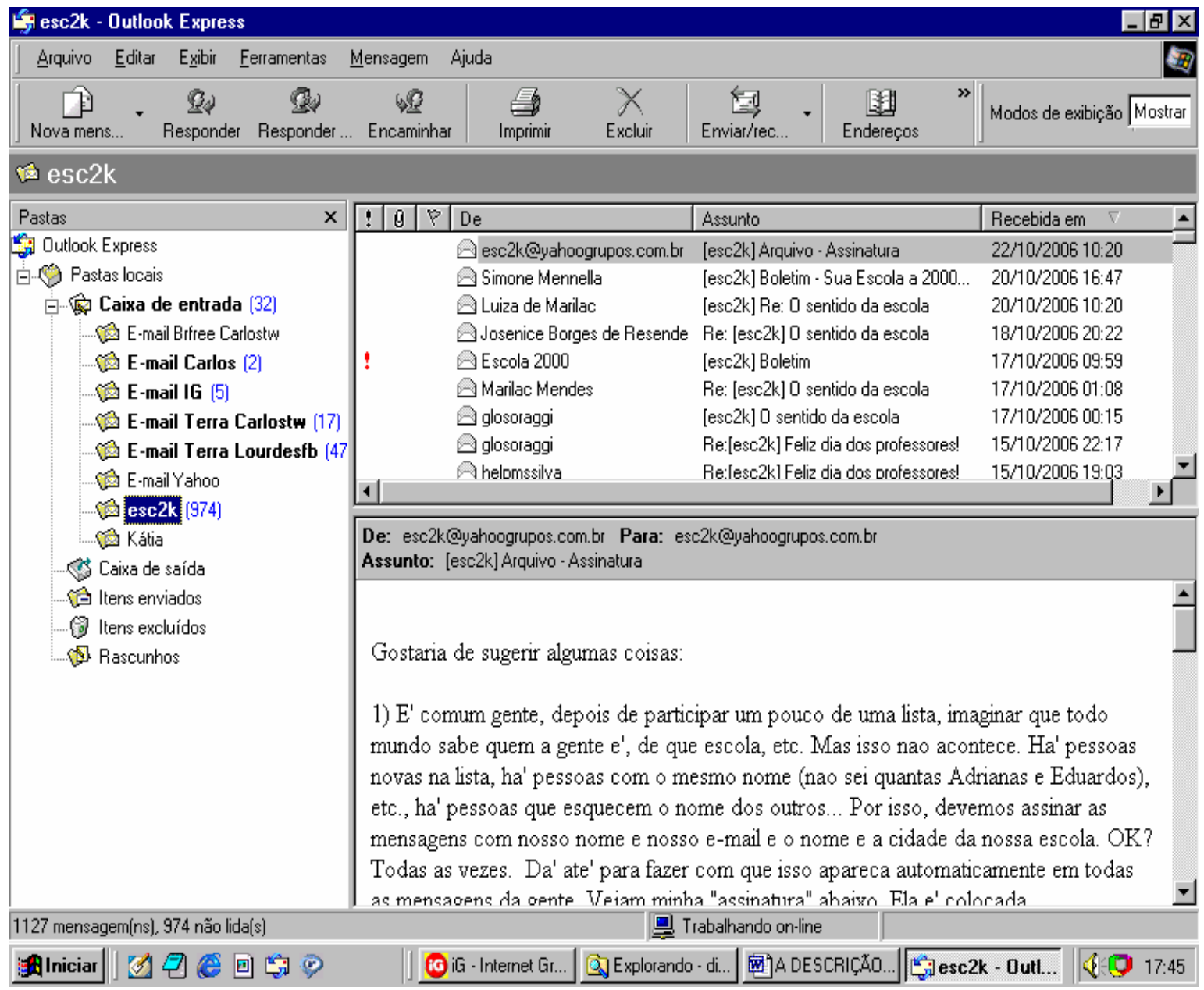

FIGURA 5 - Janela de trabalho do Outlook Express

\footnotetext{
${ }^{36}$ É um aplicativo que permite gerenciar uma ou mais contas de e-mail. Através do layout acima, permite uma navegação rápida pelas mensagens dispostas nas diversas pastas. O internauta pode clicar em cada uma dessas pastas e ter as principais ações do correio eletrônico, como ler, excluir, criar, encaminhar e responder mensagens. Essas ações são facilitadas pelas opções disponíveis em itens na barra de menus.

${ }^{37}$ A noção de conversação eletrônica será discutida no capítulo 4.
} 


\subsection{2 - O corpo}

Para fins de análise, marquei, em cada correspondência, as partes identificáveis no seu corpo. Embora nenhuma das partes seja obrigatória em uma mensagem, elas costumam seguir a seguinte ordem: cabeçalho, mensagem, assinatura, carimbo, citação da mensagem ou fragmento anterior, mensagem do grupo, propaganda do provedor, mensagem resposta, conforme figura 4.

\subsubsection{1 - Citação}

Como ficará claro no capítulo quinto, um dos problemas para o leitor de uma série de mensagens é o de contextualizar cada uma das mensagens dentro da conversação de que faz parte. Uma maneira que o autor tem para garantir que seu texto seja entendido nesse fluxo de mensagens é anexar uma cópia, nem que seja parcial, da mensagem que originou seu movimento de resposta.

Na lista Esc 2k, periodicamente circula a mensagem abaixo, no intuito de amenizar esses problemas e orientar assinantes novatos, que não possuem experiência em listas. 
A [esc2k] Arquivo - Assinatura

\begin{tabular}{|c|c|c|c|c|c|c|c|}
\hline Brquivo & Exibir & Ferramentas & Mensagem & Ajuda & & & \\
\hline Responder & Responder ... & $\begin{array}{c}69 \\
\text { Encaminhar }\end{array}$ & Imprimir & $\underset{\text { Excluir }}{X}$ & $\begin{array}{c}\text { Anterior } \\
\text { An }\end{array}$ & $\begin{array}{l}\vee \\
\text { Próxima }\end{array}$ & Endereços \\
\hline De: & \multicolumn{7}{|c|}{ esc2k@yahoogrupos.com.br } \\
\hline Data: & \multicolumn{7}{|c|}{ domingo, 22 de outubro de 2006 10:20 } \\
\hline Para: & \multicolumn{7}{|c|}{ esc2k@yahoogrupos.com.br } \\
\hline Assunto: & \multicolumn{7}{|c|}{ [esc2k] Arquivo - Assinatura } \\
\hline
\end{tabular}

Gostaria de sugerir algumas coisas:

1) E' comum gente, depois de participar um pouco de uma lista, imaginar que todo mundo sabe quem a gente $e^{\prime}$, de que escola, etc. Mas isso nao acontece. Ha' pessoas novas na lista, ha' pessoas com o mesmo nome (nao sei quantas Adrianas e Eduardos), etc., ha' pessoas que esquecem o nome dos outros... Por isso, devemos assinar as mensagens com nosso nome e nosso e-mail e o nome e a cidade da nossa escola. $O K$ ? Todas as vezes. Da' ate' para fazer com que isso apareca automaticamente em todas as mensagens da gente. Vejam minha "assinatura" abaixo. Ela e' colocada automaticamente em todas as mensagens que envio. Quem descobrir como se faz isso conta para os outros, esta' bom?

2) Quando a gente responde a uma pergunta, deve deixar, na nossa resposta, a pergunta a que a gente esta' respondendo. 'As vezes a gente acha uma mensagem que diz: "Fabuloso, adorei!!!" -- e vai tentar descobrir o que e' que e' fabuloso e... nao encontra nada! A pessoa esqueceu de deixar um pedacinho da mensagem anterior (com o nome e e-mail de quem a enviou) para permitir os outros ficassem sabendo o que ela achou fabuloso.

3) E nao nos esquecamos de NAO acentuar na linha do assunto!

Como a gente esta' comecando a ter bastante mensagens, e' bom desenvolver habitos de escrever e responder mensagens que facilitem a sua leitura e o seu entendimento pelos outros.

Eduardo

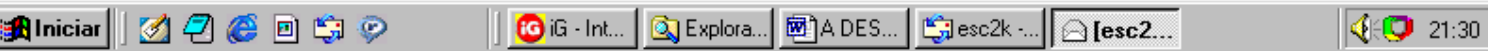

FIGURA 6 - Mensagem enviada periodicamente à lista alertando os usuários para alguns procedimentos básicos

\subsubsection{2 - Endereçamento}

A maioria das mensagens desse grupo inicia-se com algum tipo de saudação, como podemos ver nestes exemplos retirados da teia ${ }^{38} 1$ :

Oi Parceiros do Rio Grande Do Sul! (M 892);

Um Grande olá para todos os parceiros do RS e do BR. (M 952);

Oi Michael! (M 969);

Oi Marcus (M 1005);

Olá Ricardo (M 1024);

Oi Gilberto (M 1043);

Oi pessoal (M 1049); Oi Cleia e Lenise (M 1078);

Olá pessoal de Rio das Ostras, olá DriP! (M 1587);

Olá pessoal! (M 1861);

Galera da lista...(M 1900)

\footnotetext{
${ }^{38} \mathrm{O}$ conceito de teia (conjunto autônomo de fios discursivos) será aprofundado e exemplificado no capítulo 3.
} 
A cordialidade também é sinalizada por outros meios, principalmente, por expressões utilizadas na linguagem oral, simulando a aproximação face a face:

EEEEBA!!!! (M 894)

\subsubsection{3 - Mensagem}

As mensagens são os textos originais que trazem o conteúdo semântico da correspondência.

O tamanho das mensagens é muito assimétrico. Entretanto, os emissores evitam mandar mensagens longas, pois elas desestimulam os leitores, que, para acompanhar o fluxo intenso da lista, dedicam boa parte do seu tempo à leitura. Por isso, há uma regra de conduta entre os "listeiros": a de avisar o leitor, no rótulo de assunto, quando a mensagem é longa.

\subsubsection{4 - Assinatura}

Existem dois tipos de assinatura: o nome e o carimbo. Os carimbos normalmente contêm nome e endereço eletrônico, mas podem trazer também outras informações, como endereço, telefone, título, local de trabalho. Algumas vezes aparecem piadas, ditados e "arte eletrônica".

Na lista Esc 2k, percebi que apenas os participantes da lista gestora traziam carimbos; os demais usuários limitavam-se a colocar apenas o nome e a cidade de onde falavam; muitas vezes também colocavam o nome da escola. Entretanto, isso não era um procedimento padrão, pois até hoje, periodicamente, é enviada a mensagem que aparece na figura 6.

\subsubsection{5 - Anexo}

Anexos são documentos repassados de outras fontes. Eles podem ser anexados no fim da correspondência (são copiados e colados no final da mensagem), ou podem vir como arquivos anexados fora do corpo da mensagem. A lista Esc $2 \mathbf{K}$ não aceita anexos desse segundo tipo. 


\section{7 - A comunidade}

Comunidade deve ser entendida como o conjunto de membros cadastrados na lista durante o período de cada coleta. Como a lista Esc 2k é uma lista "fechada", só participam delas os assinantes. Os assinantes divulgam a existência da lista nas escolas parceiras e convidam outras pessoas dessas escolas a participarem também da lista, aumentando, assim, o número de assinantes. A lista foi iniciada com 45 membros e, em outrubro de 2006, contava com 824 assinantes.

\subsection{1 - A distribuição: os leitores}

Todos os assinantes são considerados "oficialmente" leitores. Entretanto, a lista de assinantes não reflete, com clareza, pessoas distintas. Por exemplo, um único assinante pode ter sido cadastrado com pelo menos dois endereços de e-mail diferentes. Nem todo assinante realmente lê todas as mensagens. Muitas vezes ele faz uma seleção graças ao rótulo de assunto e lê apenas as que mais lhe interessam. Como os membros da lista Esc $2 \mathbf{k}$ são, na sua maioria, professores, é um hábito comum, meu inclusive, de imprimir mensagens interessantes e passar para outros membros da escola, alunos e professores, aumentando, assim, o número de leitores ocasionais.

\subsection{2 - A participação: os autores}

Os autores das correspondências são mais facilmente identificados. Identifiquei 231 autores das 4260 correspondências do corpus. Um outro aspecto relevante é que os nomes variam muito. A qualquer momento um assinante pode mudar de endereço e é muito comum mudar a assinatura, fazendo combinações do próprio nome, mas de forma diferente.

\subsection{3 - Assiduidade}

Há uma discrepância muito grande entre a participação de alguns em relação a outros. Existem os participantes mais "falantes"; normalmente são aqueles que conhecem mais o sistema, contribuindo com mensagens de esclarecimentos, orientações, fomentando 
discussões e encorajando os demais a participar; e os lurkers (participantes silenciosos) (McCLEARY, 1996:105), também chamados por Gofman de spies (espiões). (apud MARCCOCCIA, 2004). Isso pode ser percebido pela curva que aparece na figura 7. A quantidade de participantes que contribuem com muitas mensagens é bem menor do que os que contribuem com poucas mensagens.

No estudo de Souza (2003:100), ao analisar duas listas de discussão, obtém gráfico semelhante, o que leva a classificá-la como "distribuição bipolar", pois há diferenças exageradas nos dois extremos do gráfico. O autor ainda comenta que o fato de alguns poucos membros produzirem muito e muitos produzirem pouco leva-o a crer que essa é uma divisão entre o grupo de produtores daqueles que são espectadores, no caso dos lurkers.

Acredito que no caso da lista Esc 2k não se possa fazer tal afirmação, pois grande parte dos "produtores", principalmente na fase inicial da lista, era composta por membros da equipe gestora do IAS, cuja função era fomentar discussões, dar apoio pedagógico e incentivar os demais assinantes a participar. Com o passar do tempo e com conhecimento e confiança adquiridos, houve grandes produtores entre professores e até entre alunos das escolas parceiras. Esse fato demonstra que a posição entre os assinantes não é fixa, até entre os lurkers, que podem, a qualquer momento, tornarem-se produtores, mesmo que inicialmente, com produção tímida. 


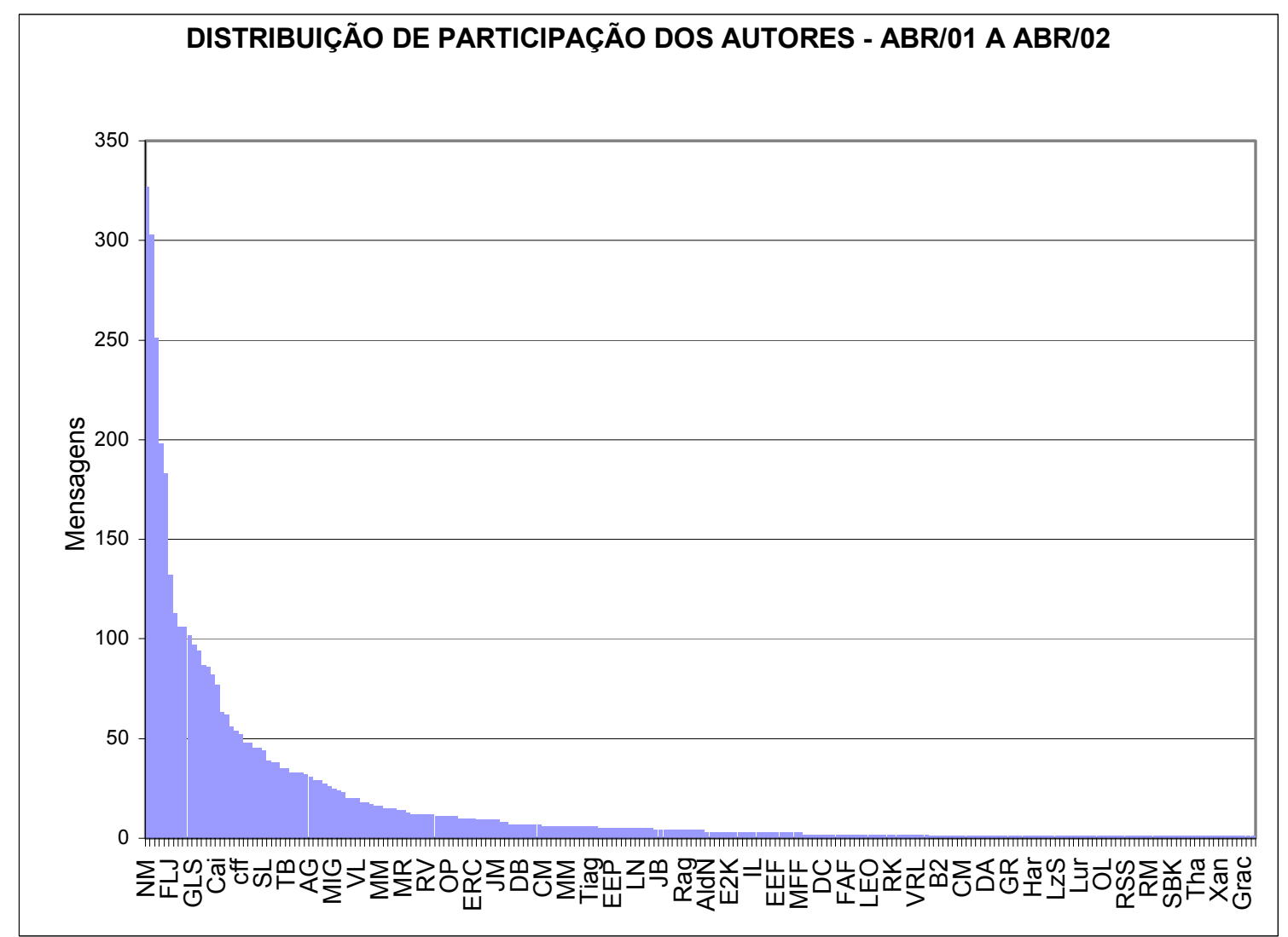

FIGURA 7 - Distribuição de participação dos autores

2.8 - O conteúdo: tipologia das correspondências

A seguir, descrevo os tipos de correspondência encontrados no corpus. Essa é uma classificação descritiva baseada na classificação de McCleary (1996). ${ }^{39}$

\section{8 .1 - Tópica $^{40}$}

A grande maioria das correspondências faz parte de algum tópico em curso, ou inicia tópicos. Tópicos são quaisquer assuntos técnicos de interesse do grupo, assuntos de interesse geral (por exemplo, oferecimento de hospedagem onde haverá um fórum) e assuntos metadiscursivos (por exemplo, problemas no horário do envio das mensagens ou a orientação para que não se acentue na linha de assunto).

\footnotetext{
${ }^{39}$ O próprio autor afirma que sua classificação é intuitiva e descritiva pelo fato de não haver ainda conceitos teóricos sobre o assunto.

${ }^{40}$ Uso o termo tópica, embora conste o vocábulo "topical" em McCleary (1996:77).
} 


\subsection{2 - Repassada}

Este tipo de correspondência serve para passar textos informativos originados fora da lista para os seus membros. No corpus estudado encontramos textos jornalísticos, frases ou citações famosas, trechos de livros, curiosidades, dicas de sites etc.

\subsection{3 - Promocional}

Nas listas "abertas", é muito freqüente repassarem informações promocionais, de acordo com a natureza da lista. Listas acadêmicas costumam receber anúncios de congressos ou lançamentos de livros, geralmente considerados bem-vindos. Entretanto, quando a mensagem faz autopromoção do remetente ou é puramente comercial, não é tolerada pelo grupo, sendo considerada como mensagem "invasora". Esse não é o caso da lista Esc 2k; as mensagens promocionais são as do próprio Instituto, e, geralmente, aparecem no site com o assunto: "Boletim"; são convites para encontros virtuais; debates em fóruns específicos; cursos em formato de educação à distância; convites para que se conheça o webfólio do mês; entrevistas periódicas que aparecem no site do "Programa sua escola" etc.

Nas páginas seguintes foram colocados dois exemplos: 


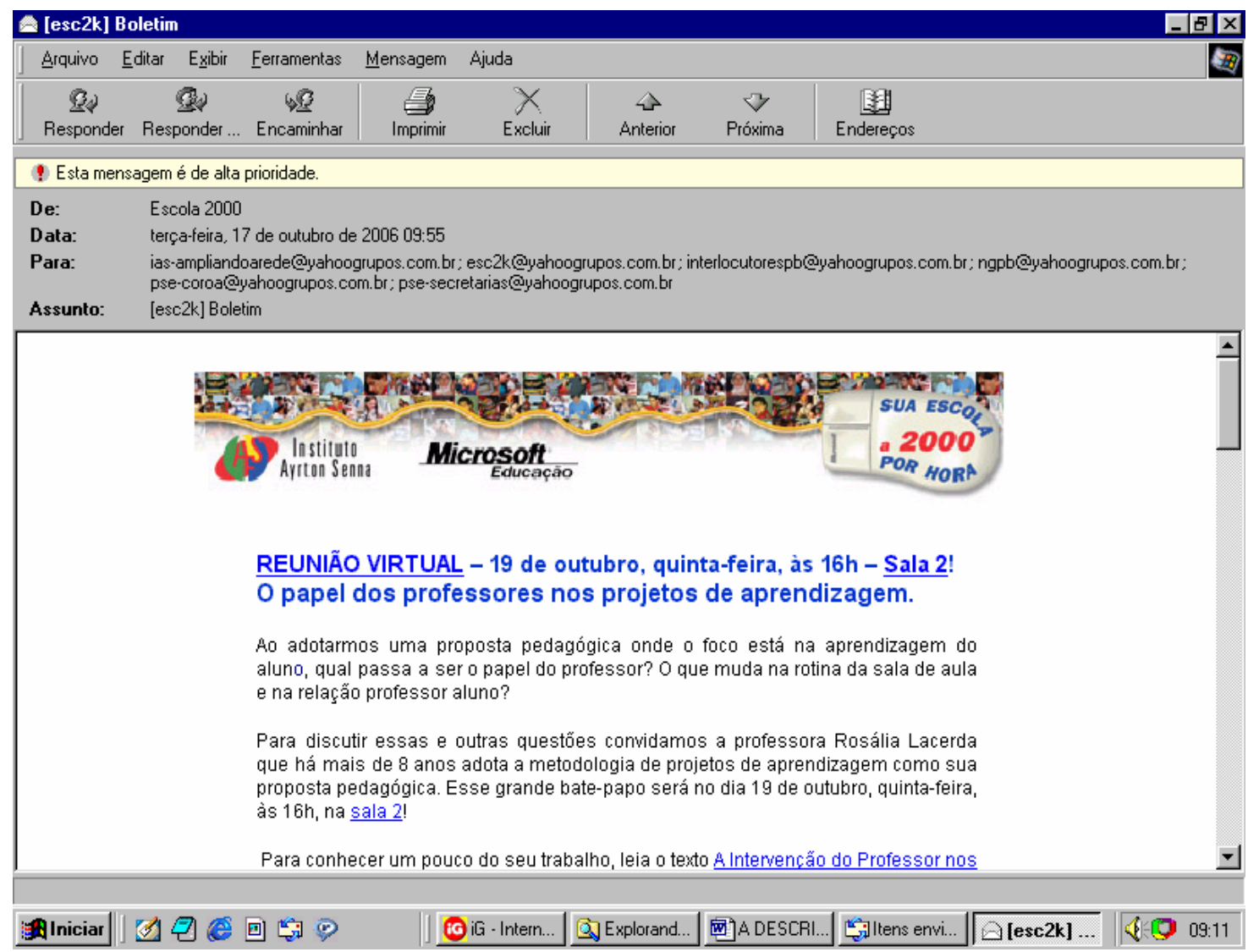

FIGURA 8: Convite para uma Reunião Virtual

Como já foi mencionado no capítulo 1, os programas sociais do IAS são divididos em duas partes: fazer e influir. Uma maneira encontrada pelo Instituto de divulgar sua metodologia para todas as pessoas que tenham interesse em melhorar a qualidade de ensino no país ${ }^{41}$ é a criação de encontros virtuais, como esse, que ocorreu em 19 de outubro de 2006. Antes, porém, de começar o bate-papo, o internauta é convidado a ler um ou mais textos sobre o assunto, para que, no momento da interação, ele tenha um subsídio maior para entender a conversa.

O convite que aparece na figura 9, é de outro programa social do Instituto, o SuperAção Jovem. ${ }^{42}$ Nesse programa, os jovens são estimulados a desenvolver projetos em equipes com o objetivo de solucionar problemas da sua escola ou da sua comunidade. Esse convite, também está associado à noção de influir:

\footnotetext{
${ }^{41}$ Para nós, participantes da lista Esc 2k, é enviada uma mensagem, que chega automaticamente à nossa caixa de correio eletrônica, a cada novo boletim. Entretanto, esse "convite" também aparece no site, e qualquer pessoa que acessá-lo tomará conhecimento e poderá participar do encontro virtual.

${ }^{42}$ Esse programa acontece em sete estados brasileiros e, em 2003, foi adotado como política pública em São Paulo, como parte do Programa Escola da Família, do Governo do Estado.
} 


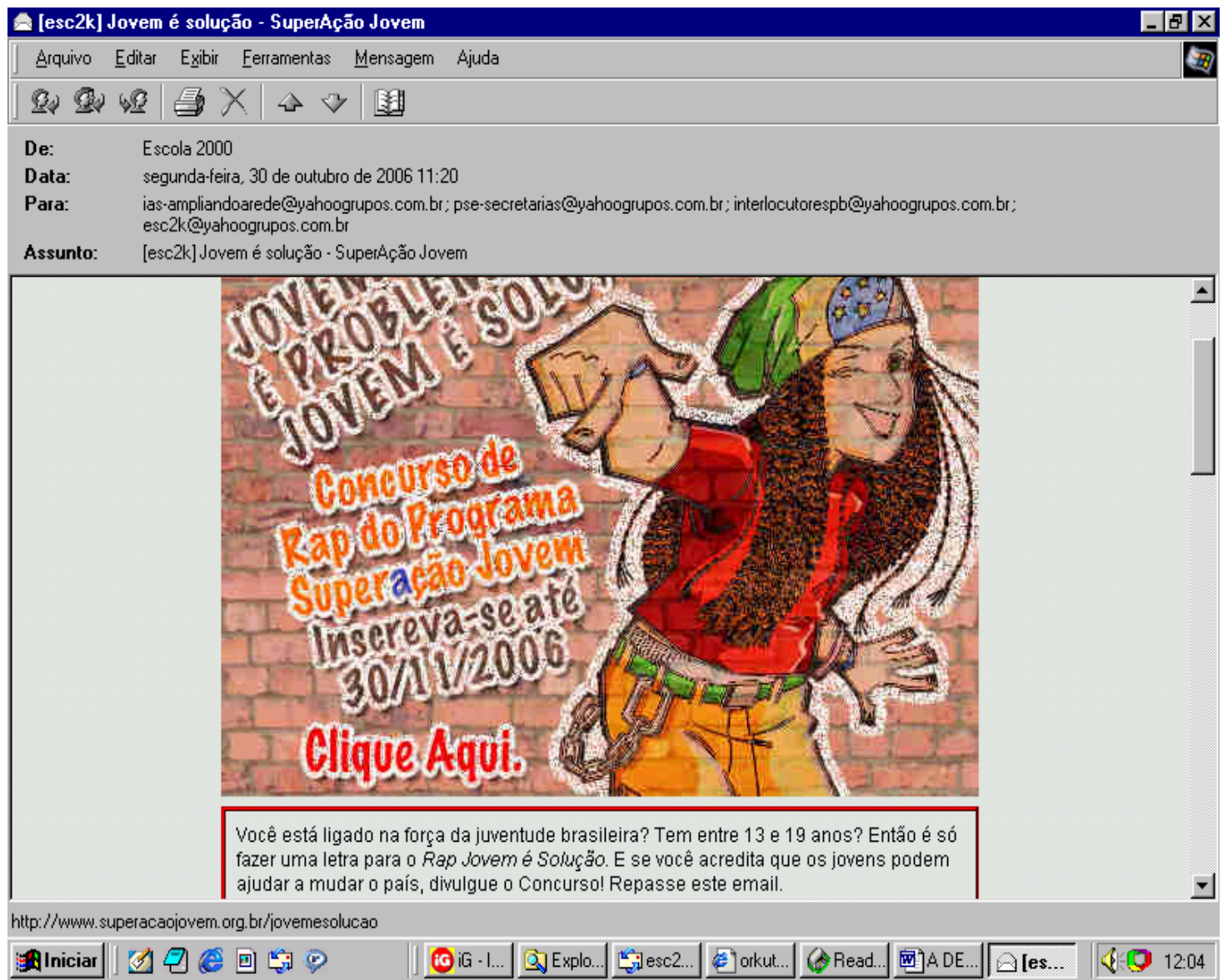

FIGURA 9: Convite sobre um concurso de rap para ser divulgado nas escolas.

\subsection{4 - Operacional}

São as correspondências cujo conteúdo diz respeito apenas ao programa de gerenciamento ou ao administrador da lista. São elas: pedidos para cancelamento de assinatura, pedido de cadastro de um novo assinante, alteração de endereço eletrônico e mensagens de teste. Geralmente, essas mensagens já trazem no rótulo de assunto seu conteúdo, sendo desnecessária a leitura pelos demais membros, como o exemplo abaixo:

De: "Faustina L. Justo

Data: Qui, 28 de Jun de 2001 9:07 am

Assunto: teste

Estou testando

Faustina (M 508) 


\subsection{5 - Particular}

Existe certa indefinição sobre o que deve ser considerada uma mensagem partícular e, por isso, não apropriada à lista, e o que deve fazer parte normal da vida de uma lista. Mensagens com conteúdo não-técnico, como o cumprimento pelo aniversário de algum membro ou o desabafo sobre problemas pessoais, são toleradas na lista Esc 2k.

\subsection{6 - Defeituosa}

São consideradas defeituosas as correspondências vazias, repetidas, extraviadas ou ilegíveis, sejam por problemas de transmissão, falhas técnicas ou humanas.

\subsection{7 - Invasora}

Esse é o último tipo elencado por McCleary (1996: 87). São consideradas inapropriadas à lista e procedem de fora da "comunidade" da lista. Como a lista Esc 2k é fechada, esse tipo de correspondência não aparece, pois só a "comunidade" envia mensagens.

\section{9 - A questão do gênero ${ }^{43}$}

Desde a década de 90, com o advento da internet no Brasil, até os dias de hoje, mais de trezentos milhões de pessoas se tornaram adeptas dessa nova tecnologia. Para muitos, essa evolução vertiginosa sugere uma nova revolução na história da humanidade, comparável à Revolução Industrial. O mundo é hoje, em boa medida, o mundo da internet. Na esteira dessa invenção, surgiram alguns gêneros textuais que, se não totalmente novos, trazem desafios novos para sua análise e compreensão. Além disso, estão exigindo uma investigação detida para que se perceba melhor como vêm interferindo nos usos lingüísticos e mudando nossas relações, em especial com a escrita.

\subsection{1 - Gêneros do discurso}

\footnotetext{
${ }^{43}$ Não houve preocupação nesse trabalho distinguir "gênero" x "tipologia".
} 
A noção de gênero tem sido uma preocupação constante. Só para ilustrar, mencionaremos as classificações mais conhecidas.

Uma primeira divisão, vinda desde o século IV, distinguia na Grécia os gêneros literários em prosa dos gêneros literários em verso. Entretanto, a tríade (dramático, lírico, épico) advinda das relações entre realidade e representação, proposta por Platão, perdura até hoje.

No gênero dramático, integravam-se as obras que se representavam sem que a pessoa do poeta interviesse; no gênero lírico, incluíram-se aquelas em que a pessoa do poeta intervinha; o gênero épico era uma espécie de mistura resultante das duas anteriores, na qual falava algumas vezes o poeta e outras vezes falavam as personagens por ele introduzidas (SILVA, 1973).

Não só na literatura, mas também na retórica, houve uma preocupação com a noção de gênero. Aristóteles concebeu também uma divisão triádica: o discurso que julga sobre o passado - judiciário; o que se pronuncia sobre o futuro - deliberativo; e aquele que se pronuncia sobre o talento do orador - epidítico. Cada gênero comporta um fim distinto, respectivamente: acusar ou defender, visando o justo e o injusto; aconselhar ou desaconselhar, com vista ao útil ou prejudicial; elogiar ou criticar, visando ao belo e ao feio, exaltando o prazer ou o desprazer.

O estudo dos gêneros foi, dessa forma, uma constante temática que interessou os antigos e que hoje tem interessado os lingüistas, na medida em que a Lingüística passa a se preocupar com o texto, e não com as unidades menores (fonema, palavra, frase), que eram a sua preocupação inicial. Quando ela passa a atentar para o texto não literário, essa atenção passa a ser crucial. (BRANDÃO, 2000:19).

\subsection{2 - As tipologias textuais na Lingüística}

Vários pesquisadores têm estudado as tipologias textuais. Brandão (2000:23), baseando-se em Adam, justifica o interesse dos pesquisadores em estabelecer uma classificação dos textos e dos discursos, afirmando que seríamos submersos pela diversidade absoluta e por uma impressão caótica dos enunciados que a regularidade das categorias textuais elimina, pois estas são elementos fundamentais de nossa organização de experiência. 
A autora ainda afirma que, no campo da Lingüística, circula uma variedade enorme de tipologias e aponta quatro tipos de classificações:

a) tipologias funcionais

É proposta por Jakobson e fundada no estudo das funções que envolvem todo ato de comunicação. Amplia o modelo triádico de Bühler, que reconheceu três tipos básicos de mensagens, conforme o acento se fizesse no destinador, no destinatário ou no contexto. Esse modelo baseava-se nas três pessoas do discurso.

Assim, a mensagem de caráter expressivo baseia-se na primeira pessoa - a que fala; a mensagem apelativa, na segunda pessoa - com quem se fala; a mensagem informativa, na terceira pessoa - de que $(\mathrm{m})$ se fala.

Jakobson acrescenta ao modelo de Bühler mais três fatores: o código (que gera a mensagem de caráter metalingüístico), o canal (que gera a mensagem que visa ao contato), e a mensagem (que gera o texto poético).

Esse modelo, embora centrado no ato de comunicação verbal, não leva em conta a dinâmica da interlocução e, por isso, recebe críticas.

b) tipologias enunciativas

Tratam principalmente da influência das condições de enunciação (interlocutores, lugar e tempo) sobre a organização discursiva. Podem ser:

i) discurso centrado no locutor (por ex. a linguagem de um diário de adolescente) em oposição àquele centrado no alocutário (a linguagem da propaganda);

ii) o discurso explícito ou autônomo em relação à situação (a linguagem teórica do discurso da ciência) em oposição ao discurso implícito ou de situação (a linguagem das relações do cotidiano);

iii) o discurso autônomo sem indicações sobre sua enunciação em oposição ao discurso que a ela se refere constantemente.

c) tipologias cognitivas

Classificam os textos em função do modo de organização cognitiva dos conteúdos. Estas abordagens visam a uma compreensão do funcionamento textual por meio de uma definição das operações subjacentes à produção e compreensão de conteúdos pelo locutor ou pelo receptor. 
A autora descreve o modelo teórico de Adam (BRANDÃO, 2000:28), afirmando que a hipótese desse lingüista se baseia na idéia de que mesmo as formas mais elaboradas e complexas de enunciados se fundam sobre certo número de formas elementares que devem ser consideradas como prototípicas.

Embora Adam reconheça que a lingüística textual não se funda em uma concepção autonomista do estudo da linguagem, considera os enunciados apenas enquanto seqüência lingüística. Entende o texto como objeto abstrato, oposto ao discurso que é concreto, produzido em uma situação determinada sob o efeito de uma rede complexa de determinações extra-lingüísticas e propõe cinco tipos de estruturas seqüenciais de base: narração, descrição, argumentação, explicação e diálogo.

d) tipologia sócio-interacionista

A autora baseia-se nos estudos de Bakhtin. Esse autor insiste no caráter social dos fatos de linguagem, considerando o enunciado, ou seja, o texto, como o produto da interação social, em que cada palavra é definida como produto de trocas sociais; o enunciado está ligado a uma situação material concreta, assim como ao contexto mais amplo que constitui o conjunto das condições de vida de uma comunidade lingüística dada.

Marcuschi (2004:17), baseando-se em Erickson, afirma que a interação via internet tem o potencial de acelerar a evolução dos gêneros, pois esse meio propicia uma interação altamente participativa. $\mathrm{O}$ autor ainda afirma que um meio tecnológico interfere no enquadre que forma a noção do gênero.

Bakhtin (2003:263-268) mostra que as esferas de comunicação são formadas por um repertório de gêneros que lhes são próprios. Por essa razão, ele mostra que, dependendo das esferas, os gêneros se dividem em dois grupos: primários e secundários. Enquanto os gêneros primários são próprios das circunstâncias de uma comunicação verbal imediata e espontânea, os secundários veiculam enunciados típicos de uma comunicação cultural mais complexa, como a escrita. Essa diferença, não é funcional, surgem nas condições de um convívio cultural mais complexo e relativamente muito mais desenvolvido e organizado, no caso do gênero escrito. Assim, ao integrar o gênero secundário, os gêneros primários se transformam, perdendo o vínculo imediato com a realidade concreta.

Araújo (2004:93) atenta para a falsa idéia de que a fala seja a modalidade privilegiada dos gêneros primários, pois uma carta, por exemplo, se manifesta pela via escrita. $\mathrm{O}$ que justifica o rótulo primário ou secundário não é a modalidade da língua usada, mas a esfera a 
que se vincula o gênero. Dessa forma, uma comunicação em um congresso científico, ainda que se apresente oralmente, será um gênero secundário, pois está relacionada a uma esfera complexa, que é a científica.

\subsection{3 - Gêneros digitais}

Dada a complexidade e amplitude da internet, os estudos lingüísticos não deram conta de estudar os vários gêneros emergentes desse novo tipo de comunicação. Esses gêneros são bastante variados, mas a sua maioria tem similares em outros ambientes, tanto na oralidade como na escrita.

Marcuschi (2004:31) traça um paralelo entre os gêneros emergentes e suas contrapartes pré-existentes, estabelecendo 12 novos gêneros: e-mail, chat em aberto, chat reservado, chat ICQ (agendado), chat em salas privadas, entrevista com convidado, e-mail educacional (aula por e-mail), aula chat (aulas virtuais), vídeo-conferência interativa, lista de discussão, endereço eletrônico, blog (grifo meu).

Esse autor ainda aponta três aspectos que tornam relevante a análise dos gêneros digitais (2004:14):

a) seu grande desenvolvimento e o uso cada vez mais generalizado;

b) suas peculiaridades formais e funcionais, não obstante terem eles contrapartes em gêneros prévios;

c) a possibilidade que oferecem de se reverem conceitos tradicionais, permitindo repensar nossa relação com a oralidade e a escrita.

Esse autor também estabelece parâmetros mínimos para se enquadrarem os gêneros. Procuraremos reproduzir alguns: número de interlocutores; tempo de espera e de envio de mensagens; quantidade permitida de texto; método de armazenamento, busca, gerenciamento dos textos. (MARCUSCHI, 2004:32-3)

$\operatorname{Machado}^{44}$ (s/d:117-124) em artigo em que pretende mostrar que a interação não é um fenômeno exclusivo da linguagem natural, mas também ocorre nas linguagens artificiais, entende, apropriando-se de Bakhtin, que toda mensagem representa esferas específicas de usos da linguagem. "Considerando-se que as formas de organização das mensagens são tão

\footnotetext{
${ }^{44}$ Essa autora (s/d:123) assim como Marcuschi (2004:29) e Marcoccia (2004:117) baseia-se em textos de Erickson: no caso de Marcuschi: Erickson (1997 e 2000); no caso de Machado: Erickson (1996 e 1998); no caso de Marcoccia: Erickson (1999).
} 
infinitas quanto as possibilidades de uso da língua, pode-se dizer que os gêneros representam, igualmente, infinitas possibilidades de uso da linguagem (...)” (p 119).

A autora defende a idéia de que a comunicação mediada por meios, quaisquer que sejam eles, como rádios, satélites, bits, produz mensagens, logo, produz gêneros. Desse modo, o contexto digital é entendido como um ambiente potencializador de linguagens artificiais, onde as formas comunicativas processadas digitalmente se inserem em uma nova esfera de uso da linguagem, dando início, ao que a autora denomina de gêneros digitais (p 121).

\subsection{4 - Grupo de discussão: um novo gênero textual}

De acordo com Paiva (2004:76), e com base em suas leituras de diversos autores, entre eles Bakhtin e Marcuschi, gêneros textuais são sistemas discursivos complexos, socialmente construídos pela linguagem, com padrões de organização identificáveis, dentro de um continuum de oralidade e escrita, e configurados pelo contexto sócio-histórico que engendra as atividades comunicativas.

A autora, baseando-se em Bronckart, afirma que atualmente qualquer espécie de texto observável pode ser considerado como pertencente a um determinado gênero. Araújo (2004:93) parte da noção bakhtiniana de esfera comunicativa e afirma que à medida que uma esfera se torna mais complexa, os gêneros, para dar conta das novas necessidades que se instauram nessas esferas, sofrem uma transmutação, gerando novos gêneros.

O autor entende a $\mathrm{Web}$ como esfera eletrônica, um espaço de práticas humanas de comunicação, que originará muitos gêneros para organizar as práticas linguajeiras vividas ali. Todos os gêneros emergentes da Web trazem a marca desta esfera (2004: 96). O autor exemplifica dizendo que o diálogo cotidiano, considerado um gênero primário, ao ser transmutado de sua esfera de origem para o romance, por exemplo, que é um gênero secundário, sofre alteração do seu estilo. Ao ser transportado para a esfera eletrônica, o processo é semelhante.

Nesse sentido também Machado entende os gêneros digitais e classifica tanto os chats quanto as listas de discussão como "gêneros conversacionais fundados no diálogo". A respeito dos chats, afirma que não há exemplo mais direto de um gênero discursivo online; sobre lista de discussão afirma que "nenhum gênero processado digitalmente representa tão bem o diálogo socrático" (p. 124). 
Nos grupos/listas de discussão, pode-se conversar "de forma escrita", o que nos faz pensar em uma fusão entre carta e conversa, pois, embora não seja o propósito, algumas vezes, há quase uma sincronicidade: perguntas e respostas ocorrem com intervalo de tempo de minutos. Marcuschi, ao comparar os gêneros emergentes aos gêneros já existentes, contrapõe lista de discussão a circulares/série de circulares e ainda acrescenta três pontos de interrogação (???) (2004:31). Isso demonstra a dificuldade em classificar esses grupos. De fato, não concordamos com essa comparação, pois uma circular é uma carta, ofício ou manifesto que foi reproduzido e mandado a muitas pessoas, não comportando resposta. Nos grupos, se não houver intercâmbio, a atividade perde sua função. Nesse sentido, concordamos com Araújo (2004:95), ao basear-se em Pagano, e afirmamos que grupo de discussão é um exemplo de novo gênero, surgido a partir de transformações de gêneros existentes, híbrido de carta, telegrama e de outros gêneros, mas com uma identidade genérica própria, vinculada às condições tecnológicas de sua produção e a uma comunidade discursiva que faz uso dele. 
Olá, pessoal!.

Será que a equipe da América Abdalla (Rio das Ostras) leu a mensagem da Vand., que era sobre o Encontro de RO, mas estava com o assunto "Laboratório de Informática"? Talvez não tenham lido e, se eu também não tivesse lido, a Vand. poderia ficar sem as informações que deseja.

Além disso, o texto inteiro do resumo diário da Mar. veio embaixo da mensagem da

Vand. E isso não é apenas uma prática da Vand. - nova na lista e muito bemvinda!!! Vejo isso acontecendo regularmente. Acredito que muitas trocas de informações se percam por causa de "assuntos" que não dizem respeito ao verdadeiro conteúdo da mensagem.

Vão aqui duas dicas: 1. prestar atenção à linha de assunto, sempre colocando assunto referente ao conteúdo da mensagem; 2 . Deixar somente no corpo da mensagem a parte que interessa da mansagem anterior. $O$ que não interessa pode ser deletado. Pode ser apagada, também, aquela parte que vem embaixo falando "Para cancelar sua assinatura deste grupo, envie um e-mail em branco para:"... Acho que isso facilitaria um pouco a leitura das inúmeras mensagens que chegam para todos diariamente.

Enviarei todas as informações do Encontro de RO já circuladas aqui para a Vand., pelo e-mail particular dela!

Beijos,

Bel

(M-1992, Teia 1 - negritos meus)

\section{A FORMAÇÃO DE UM SUBCORPUS: MONTAGEM DAS TEIAS}

O corpus da pesquisa é composto por 4260 mensagens (cf item 2.4, p 41). Para fins de uma análise mais profunda, decidimos montar e estudar as teias (conjuntos autônomos de fios ${ }^{45}$ discursivos) de um período e escolhi o mês de agosto de $2001^{46}$ para fazê-lo. Esse mês mostrou-se o ideal, por vários motivos. Agosto foi o mês com maior fluxo de mensagens. Em 2001 aconteceu a premiação da segunda edição do concurso "Sua escola a 2000 por hora", aumentando o número de escolas participantes e em conseqüência disso, o número de assinantes da lista. Em 2001 a lista já estava um pouco mais madura, pois os participantes das 20 escolas premiadas na primeira edição já possuíam algum conhecimento em Listas de Discussão. Por alguns problemas de ordem técnica, algumas escolas da primeira edição só tiveram a internet instalada em fins de 2000 ou início de 2001, passando, a partir desse período a interagir na lista de forma mais efetiva.

\footnotetext{
${ }^{45}$ Fio é um conjunto de correpondências que trata de um tópico ou conjunto de tópicos afins e que são interrelacionadas (McCLEARY, 1996:140)

${ }^{46}$ Agradeço ao Prof. Dr. Leland McCleary por essa sugestão.
} 
2001 também foi um ano bastante propício para o grupo, com vários encontros entre escolas parceiras, o que propiciou maior interatividade na lista. $\mathrm{O}$ primeiro grande encontro foi a Semana de Imersão em Tecnologia Digital, em Faxinal do Céu/PR. Esse encontro aconteceu de 17 a 21 de março e participaram diretores, professores e alunos de três escolas premiadas no ano anterior (as de Crato/CE, Campos de Goytacazes/RJ, e Nova Prata/RS), uma equipe composta pelos onze orientadores que acompanhariam as 36 escolas ao longo daquele ano, os consultores do programa e outros profissionais que iriam atuar em áreas específicas da programação.

\section{1 - A dinâmica das teias}

Como as teias se comportam? Todas têm começo e fim? Ou ao invés de terminar, as teias costumam se transformar progressivamente, até se tornarem irreconhecíveis? Existe um tamanho médio para as teias? Um tamanho limite? Mantêm-se, sempre, o mesmo número de teias em pauta, umas sendo substituídas por outras? O que se discute nessas teias? Existe algum assunto recorrente, ou eles vão mudando progressivamente?

Para responder a essas questões, explico como elas foram agrupadas.

\section{2 - Os critérios}

Estabeleci, inicialmente, como subcorpus de pesquisa, todo o volume de correspondência da Esc 2k de agosto de 2001 (760 mensagens). Elas foram lidas uma a uma e, manualmente, foram divididas em pequenos grupos cujo conteúdo semântico estava relacionado. Nesse primeiro levantamento, já pude perceber que as conversas não se iniciam e terminam em um único mês e por isso fiz o mesmo levantamento para os meses de julho, setembro, outubro e novembro de 2001.

Durante a montagem das teias, guiei-me pelo conteúdo semântico de cada mensagem, não levando muito em consideração o rótulo de assunto, que aparece no cabeçalho (cf 2.6.1, p 44 e 46), pois ele é muito traiçoeiro (McCLEARY, 1996: 142). É comum ao assinante simplesmente responder a uma mensagem enviada (nesse caso ele não precisará preencher o rótulo de assunto) e escrever uma mensagem sem nenhuma relação com o assunto a que ele 
"em princípio" se dispõe a responder ou comentar. No caso da lista Esc 2k, muitos participantes não sabiam usar corretamente o sistema e isso acontecia com freqüência.

Também não segui rigorosamente as mensagens respostas (cf item 2.6, p 46), pois essas são geradas automaticamente pelo sistema a partir do rótulo de assunto. Isso gera um fenômeno observado nas mensagens respostas: como alguns assuntos são recorrentes nessa lista, é possível encontrar mensagens respostas com datas de um, dois, ou até três anos de diferença da mensagem inicial. Facilmente percebe-se que essas mensagens defasadas não fazem parte da teia em andamento. Abaixo coloco dois exemplos:

1) Na mensagem 1027, de 12 de agosto de 2001, pertencente à teia 36, temos no rótulo de assunto: "Feliz Dia dos Pais", e o texto:

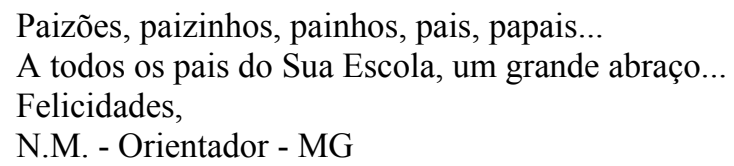

Logo abaixo da mensagem, gerada automaticamente pelo sistema, aparece a mensagem $13693^{47}$ agrupada (ou seja, o sistema "entende" como parte do mesmo conjunto, como uma mensagem resposta). Essa mensagem, cujo título é , Feliz Dia dos Pais , enviada por M.R. em 8 de agosto de 2004. Essa mensagem foi enviada três anos depois, certamente não faz parte da mesma teia.

2) Na mensagem 766, de 1 de agosto de 2001, pertencente à teia 5 , temos no rótulo de assunto: "Novos membros," e o texto:

\begin{abstract}
Olá pessoal!
Ontem fui na Escola do Sapopemba - SP e nosso encontro foi muito legal! Tive oportunidade de conhecer melhor o corpo docente. Fizemos uma atividade onde todos puderam conhecer um pouco como cada um estará trabalhando em agosto com seus alunos e depois surgiram algumas propostas para um trabalho interdisciplinar, sendo muitas delas bem interessante. Agora o mais legal é que seis novas pessoas (três alunos e três professores) juntaram-se ao nosso grupo. Sejam bem vindos! Um abraço

L.S.
\end{abstract}

Em seguida à mensagem, aparecem como mensagens respostas:

a) a mensagem 768, com o título Re: Novos membros (Re significa resposta e é gerado automaticamente quando o usuário tecla no ícone responder), enviada por N. M. em 1 de ago de 2001;

\footnotetext{
${ }^{47}$ Deixo de reproduzir o conteúdo da mensagem por não considerar relevante para o entendimento do assunto tratado.
} 
b) a mensagem 770, Re: Novos membros, enviada por L. S.em 2 de agosto de 2001;

c) a mensagem 773, Re: Novos membros, enviada por Niv. em 2 de agosto de 2001;

d) a mensagem 777, Re: Novos membros, enviada por N. M.em 3 de agosto de 2001;

e) a mensagem 775, Re: Novos membros, enviada por E. A. em 3 de agosto de 2001;

f) a mensagem 787, Re: Novos membros, enviada por A.P. em 3 de agosto de 2001.

Lendo o conteúdo das mensagens dos itens de -a a -f, percebe-se que todas fazem parte da teia 5. Entretanto, não acontece o mesmo com as seguintes mensagens:

g) mensagem 7510, Novos membros, enviada por N. M.em 29 de novembro de 2002;

h) mensagem 8243, Novos membros, enviada também por N. M. em 20 de fevereiro de 2003. Elas foram enviadas anos depois, não pertencendo à mesma teia.

Diante do exposto acredito que a mensagem resposta pode auxiliar o pesquisador e o usuário, mas em alguns momentos, pode atrapalhar. Nos dois exemplos aparecem mensagens não pertencentes à teia em curso. Entretanto, no exemplo 2, aparecem algumas mensagens corretamente agrupadas. Isso mostra que o software ainda precisaria evoluir. A pesquisa de McCleary, de 1996, já aborda esta questão, cuja solução ainda não foi encontrada.

Entretanto, a citação anterior (cf item 2.6, p. 44), quando bem usada, é uma ferramenta muito útil ao pesquisador, pois, ao deixar um fragmento da mensagem anterior, o emissor situa o leitor. Infelizmente essa não é uma prática corrente nessa lista, gerando mensagens periódicas onde se pede que os assinantes se habituem a essa prática.

Em seguida, dou dois exemplos sobre essa questão. No primeiro, onde há o pedido para que haja essa prática; no segundo, uma mensagem adequada, onde o emissor deixou o fragmento necessário para que os assinantes entendessem seus comentários e situou o leitor.

a) A mensagem 1992, de M.I.G., e enviada em 6 de outubro de 2002, pertencente à teia 1 (cf. anexo, p 142-146 ). O rótulo de assunto diz: "Confusão entre assunto e conteúdo das mensagens". Pela sua importância, coloquei o texto dessa mensagem como epígrafe desse capítulo, deixando em negrito os trechos onde a assinante destaca esse problema e propõe soluções.

Essa é uma preocupação de vários assinantes. O fluxo de agosto de 2001 foi intenso. Havia dias em que havia mais de 50 mensagens. Nesse período houve a entrada de vários assinantes, oriundos das escolas da $2^{\text {a }}$ edição do concurso, sem experiência em listas de discussão. 
Junto com a mensagem, sabiamente é deixada a pergunta da Vand., além do cabeçalho da m.-rs, para quem Vand. dirigiu a pergunta. Reproduzo o conteúdo a seguir:

\author{
-----Original Message----- \\ From: Vand. \\ Sent: quinta-feira, 4 de outubro de 2001 00:43 \\ To: esc2k@... \\ Subject: Re: [esc2k] Laboratório de informática
}

Olá M.,

Gostaria de saber sobre esse encontro que irá acontecer, é a primeira vezb que envio uma mensagem e estou bastante por fora dos acontecimentos, sou da Escola Estadual Carlos Pereira Barbosa, de Rondonópolis-MT,

Até mais,

Vand.

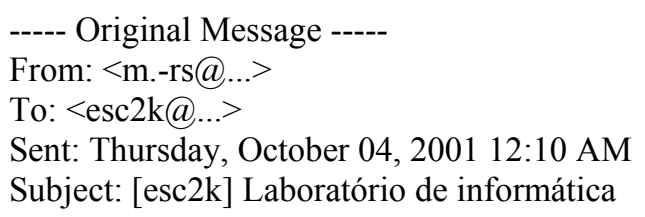

b) A mensagem 1049, pertencente à teia 1 (cf anexo, p 142-146), enviado por L.A.M.G., em 13 de agosto de 2001, com o assunto: Re: [esc2k] Escolas com surdos [Era: Para R. M.].

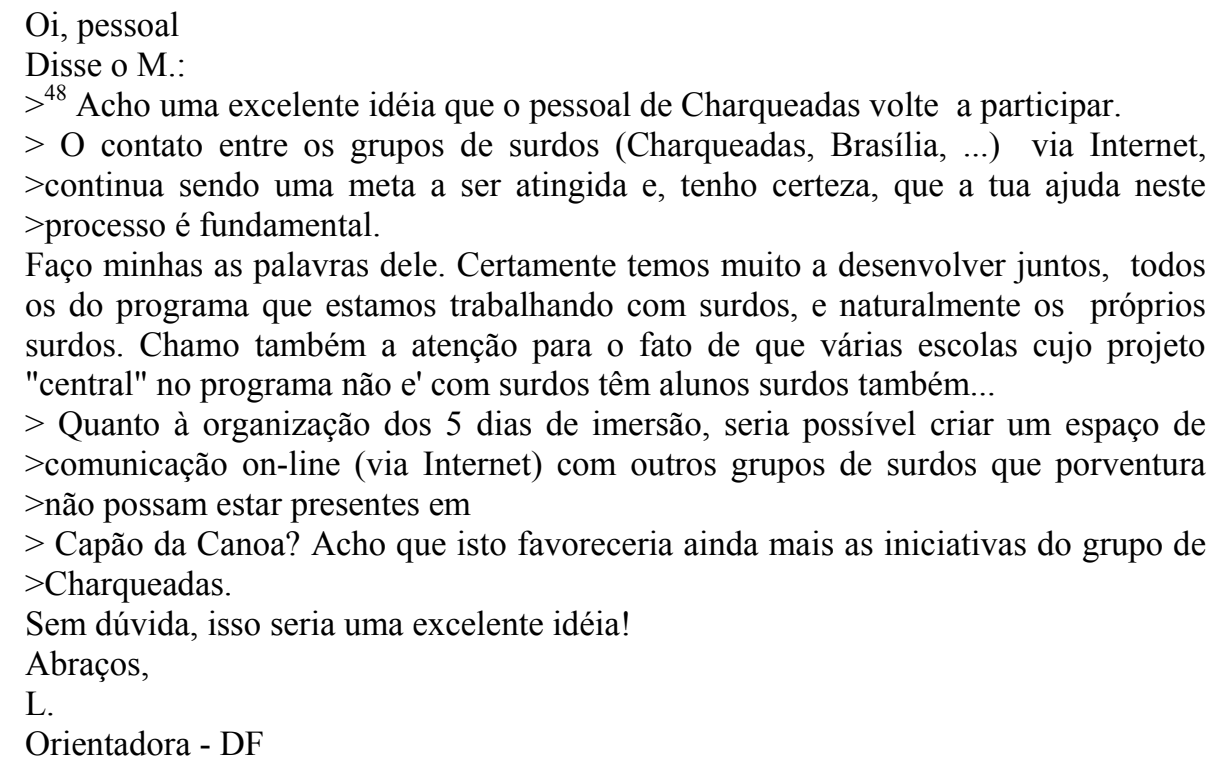

\footnotetext{
${ }^{48} \mathrm{O}$ sinal " >" é gerado automaticamente pelo sistema quando o assinante clica no ícone responder, ou seja, é uma mensagem resposta. O que L. faz é uma simbiose da fala dela com a do M., fazendo comentários logo abaixo às falas dele.
} 
A mensagem de L.G. é bastante clara, além de mostrar as facilidades do sistema. Não foi preciso escrever um texto dela relatando tudo o que o M. já havia dito. Ela só teve o trabalho de acrescentar seus comentários.

Voltando à montagem das teias, em um segundo momento, comecei a juntar os pequenos grupos a outros, formando grupos maiores (lembrando que nessas tabelas, foi colocado apenas o número de cada mensagem, e não o texto). Foram vários os momentos de leituras e releituras das mensagens, em um movimento de vai e vem até serem montadas todas as teias, e colocadas em tabelas. Ao finalizar as tabelas, elas ficaram da seguinte forma: 37 teias, sendo que a teia $n^{0} 1$ possui o número das 115 mensagens correspondentes a ela, e a $n^{0}$ 37 possui o número das 5 mensagens correspondentes a ela.

No material coletado ainda havia pequenas teias, com 1, 2, 3, e 4 mensagens cada, que foram colocadas em tabelas, de forma separada, não fazendo parte, portanto, das 37 teias citadas anteriormente. Essas tabelas possuem as mesmas informações que as teias do subcorpus. Elas foram agrupadas em virtude do tamanho diminuto.

Dessa forma, criei:

a) uma tabela onde foram agrupadas mensagens que não geraram nenhuma mensagem resposta;

b) outra tabela com a mensagem inicial e a mensagem resposta;

c) uma terceira tabela, com a mensagem inicial e duas mensagens relacionadas à primeira;

d) uma quarta tabela, com a mensagem inicial e três mensagens relacionadas à primeira. É a menor delas, e está reproduzida abaixo:

\begin{tabular}{|l|l|l|l|l|l|l|}
\hline \multicolumn{7}{|c|}{ TABELA 4 } \\
\hline$N^{\mathbf{N}}$ & \multicolumn{1}{|c|}{ TÍTULO } & PERÍODO & \multicolumn{4}{c|}{ Mensagens } \\
\cline { 4 - 7 } & & & $1^{\mathrm{a}}$ & $2^{\mathrm{a}}$ & $3^{\mathrm{a}}$ & $4^{\mathrm{a}}$ \\
\hline 1 & Drogas e defasagem escolar & $15 / 8$ & 1108 & 1113 & 1130 & 1142 \\
\hline 2 & Procura-se amigo & $28 / 8$ a 31/8 & 1425 & 1437 & 1443 & 1515 \\
\hline 3 & Minha primeira vez & $30 / 8$ & 1478 & 1480 & 1481 & 1499 \\
\hline 4 & Visita do N.M. & $30 / 8$ a 31/8 & 1344 & 1386 & 1484 & 1493 \\
\hline 5 & Notícias de SP & $31 / 8$ & 1509 & 1510 & 1511 & 1512 \\
\hline 6 & Novas metodologias & $31 / 8$ & 991 & 1018 & 1030 & 1143 \\
\hline
\end{tabular}


Nessa tabela, o leitor encontra o título, em geral, o mesmo da primeira mensagem, o período em que a conversa ocorre e o número de cada uma das mensagens. Gostaria de lembrar que a cada uma dessas tabelas corresponde um outro documento, com o texto dessas mensagens.

O processo de confecção dessas pequenas teias foi o mesmo que a das demais. Segui o conteúdo semântico, sem me guiar muito pelo rótulo de assunto e a citação anterior. Entretanto, pela baixa interatividade dessas teias, elas foram desconsideradas do estudo, não constando do anexo.

\section{3 - O processo de montagem}

No momento da nomeação das teias, tive o cuidado de não manter simplesmente o título da primeira mensagem, embora isso ocorra na maioria das vezes, onde o título, ou foi mantido integralmente ou foi parcialmente mantido. Isso aconteceu porque às vezes agrupei informações, pois as teias iam se ramificando, com fios em que o assunto se desviava do assunto principal. Em alguns momentos, teias que começam autônomas, em determinado momento juntam-se a outras, formando uma única e grande teia, como é o caso da teia número 1 (cf. anexo p. 142-146), onde eventos aparentemente isolados, um fórum no RS e outro no RJ, juntam-se no momento em que aconteceram simultaneamente com interação via chat entre os dois grupos de escolas.

O título da teia 2 (cf. anexo p.147-151) é um exemplo da manutenção do título dado pelo emissor da primeira mensagem. Optei pelo genérico "curiosidades", pois o processo de formação dessa teia é tão curioso, que fugiu ao padrão das demais. Nela, a aluna J.R.P. inicia a teia dizendo que dividirá com os demais, algumas "curiosidades" que encontrou em uma lista telefônica. Para não cansar o leitor, ela decide então dividir essas curiosidades de três em três, enviando, quase diariamente uma mensagem com as tais curiosidades. Os assuntos dessas mensagens são muito diversos, sendo que algumas delas geram dois fios interessantíssimos, e outras, geram fios menores ou não geram comentário algum.

Um dos dois fios mais importantes, sobretudo pelo fator da dialogicidade, foi iniciado pela mensagem 882 que trata de mitologia. Parte do conteúdo desse fio será comentado no capítulo 4, no item em que discuto a alternância de falantes. 
O segundo fio mais importante e complexo dessa teia é iniciado com a mensagem 1107, onde se afirma que o compositor Beethoven despejava água gelada na cabeça para estimular seu cérebro a compor músicas. Essa afirmação gera mensagens em que professores discutem quais seriam as melhores estratégias para estimular os alunos.

O número das mensagens correspondentes a cada teia foram agrupadas em tabelas, (em ordem descrescente, ou seja, as teias de números menores são as mais complexas, com maior número de mensagens), nomeadas (de acordo com o assunto abordado). Destaquei o número total de mensagens e o período de envio.

Em seguida, todas as mensagens de cada teia foram relidas. Fiz uma síntese do assunto de cada teia para que o leitor pudesse entender do que se tratava, pois o subcorpus consta de 650 mensagens, somando aproximadamente 531 páginas impressas (2,81 mb). Dado o excessivo número de páginas, optei por deixar no anexo, apenas a teia diagramada e a síntese, excluindo o conteúdo da mensagem. Por esse motivo, ao exemplificar uma teia inteira ou parte dela, reproduzo o conteúdo das mensagens mais pertinentes ao exemplo

Para que o leitor possa entender melhor esse processo, selecionei uma teia relativamente pequena, mas com um conteúdo bastante significativo, e a reproduzo passo a passo, desde a confecção da tabela, as mensagens da teia, sua síntese e o diagrama. Exemplo:

a) o número das mensagens na tabela

Agora, reproduzo a teia 21 , da maneira como foi composta inicialmente. Junto à tabela, eu colocava alguns dados para me orientar. Eram eles: título- "Martin Luther King", o número de mensagens- 9, e o período - de 17 a 28/08:

\begin{tabular}{|c|c|c|}
\hline \multicolumn{3}{|c|}{ Teia 21 } \\
\hline $\begin{array}{c}\mathrm{N}^{\mathbf{o}} \text { de } \\
\text { ordem }\end{array}$ & \multicolumn{2}{|c|}{ Mensagens } \\
\hline 1 & 1201 & 1292 \\
\hline 2 & 1258 & 1294 \\
\hline 3 & 1260 & 1311 \\
\hline 4 & 1262 & 1419 \\
\hline 5 & 1291 & \\
\hline
\end{tabular}


b) o conteúdo das mensagens

Em seguida, reproduzo cada uma das mensagens, em ordem crescente. Primeiro aparecerá apenas o número da mensagem, em seguida o cabeçalho e depois o corpo do texto. Foram retiradas os números das mensagens respostas e as citações anteriores, pois aumentava demasiadamente o texto, além ser repetitivo, pois todas as mensagens dessa teia serão reproduzidas.

\author{
Mensagem 1201 \\ De: "E O C C" \\ Data: Sex Ago 17, 2001 10:58 pm \\ Assunto: Martin Luther King Jr: "Eu tenho um sonho"
}

Estou escrevendo um livrinho que fala (entre outras coisas) de sonhos.

Resolvi, então, para colocar num "box", traduzir o belissimo discurso de Martin Luther King, Jr, "I Have a Dream", feito nos degraus do Memorial Lincoln, em Washington, DC, no dia 28 de agosto de 1963, no auge da luta pelos direitos civis nos Estados Unidos -- alguns meses antes do assassinato do presidente John F. Kennedy (22 de Novembro de 1963) e poucos anos antes do assassinato do proprio Martin Luther King, Jr. (4 de abril de 1968) e de Robert Kennedy (6 de junho de 1968), irmao do ex-presidente. Eu estudava nos Estados Unidos em 1968 e lembrome ainda, como se fosse hoje, do choque que foi esses dois lideres assassinados com apenas dois meses de intervalo.

Compartilho com voces esse lindo discurso - lindo no conteudo e na forma. Espero que a traducao nao tenha feito desaparecer a beleza da forma.

Dia 28 deste mes o discurso fara' 38 anos. Quem sabe algumas escolas possam dedicar parte do dia para refletir sobre esse texto.

E.C.

“Eu Tenho um Sonho" (“I Have a Dream”)"49

Martin Luther King, Jr.

Cem anos atrás, um grande americano, em cuja sombra simbólica hoje aqui estamos, assinou a Proclamação da Emancipação dos escravos. Este significativo decreto tornou-se a luz de um farol que trouxe esperança para milhões de negros escravos que haviam ficado ressequidos nas chamas de fulminante injustiça. Ele veio como uma alegre aurora que punha fim à longa noite do cativeiro. Mas cem anos depois, devemos ainda enfrentar o trágico fato de que o negro ainda não é livre.

\title{
(...)
}

Quando deixarmos que soe a liberdade, quando a deixarmos soar em cada cidade de cada estado e em cada região de cada cidade, seremos capazes de apressar o dia em que todos os filhos de Deus, homens pretos e homens brancos, judeus e gentios, protestantes e católicos, serão capazes de unir suas mãos e cantar as palavras do

\footnotetext{
${ }^{49}$ Apesar do conteúdo belíssimo do famoso discurso de Martin Luther King, Jr, optei por deixar apenas o $1^{\circ}$ e o útimo parágrafos, pois o discurso inteiro ocuparia duas páginas e meia de texto.
} 
velho spiritual dos negros: "Finalmente livres! Finalmente livres! Graças a Deus Todo poderoso, somos

finalmente livres!"

Tradução de E. C., 17 de agosto de 2001

$* * *$

Mensagem 1258

De: J. R. P.

Data: Seg Ago 20, 2001 5:49 pm

Assunto: Re: [esc2k] Martin Luther King Jr: "Eu tenho um sonho"

Olá!

Enquanto lia a tradução do texto, lembrava-me do filme "Mississipe em Chamas", que por algumas vezes o autor refer-se a essa cidade. É um filme um pouco firte, porém nos faz pensar como a nossa sociedade está organizada e cheia de preconceitos. Apesar de ser um texto não muito atual, mas a falta de liberdade que há entre nós e principalmente dentro de nós, é que nos castiga e faz com que hoje, sejamos pressos a tantas coisas ,ue na sua maioria,não vão nos beneficiar.

J.

Crato-ce

***

Mensagem 1260

De: O. N.

Data: Seg Ago 20, 2001 6:01 pm

Assunto: Re: [esc2k] Martin Luther King Jr: "Eu tenho um sonho"

J. e E.,

Eu também me lembrei muito de um filme quando li o discurso do Martin Luther King - o filme novo do Spike Lee, que está nos cinemas. Se não me angano ele se chama "Hora do Show". Esse filme mostra o preconceito racial da forma que ele se manisfesta atualmente na sociedade. É um filme muito pesado, mas eu gostei muito.

Fiquei também com vontade de procurar um pedaço do discurso gravado do Martin L. K. que certamente deve existir na Internet. O discurso é em inglês, mas a força e paixão com a qual o Martin L. K. fala são impressionantes. Se alguem souber sobre tal site, me avise...

Abraços, T.

Mensagem 1262

De: J. R. P.

Data: Seg Ago 20, 2001 6:25 pm

Assunto: Re: [esc2k] Martin Luther King Jr: "Eu tenho um sonho"

$\mathrm{T}$, você pode informar se o filme que você citou, já chegou nas locadoras?

Abraços

J.

$* * *$

Mensagem 1291

De: O. N.

Data: Ter Ago 21, 2001 10:07 am

Assunto: Re: [esc2k] Martin Luther King Jr: "Eu tenho um sonho"

Oi J., 
O filme "A Hora do Show" do Spike Lee ainda está passando nos cinemas, então acho que ainda demora um pouco para sair em vídeo.

Achei na Internet esse resumo do filme: "Pierre Delacroix é executivo de um canal de televisão, e precisa lutar contra a perda de audiência. Ele é negro, e seu chefe, o branco Dunwitty, vive dizendo ser mais negro que o próprio Pierre, pois além de não ser racista, se casou com uma mulher negra e tem dois filhos. Cansado disso tudo, o executivo decide jogar pesado e, quem sabe, conseguir ser demitido: ele reinventa os "minstrel shows", uma espécie de espetáculo em que atores brancos pintavam o rosto para passarem por negros, retratando-os da forma mais preconceituosa possível.

Mas, em vez de brancos, Pierre contrata dois negros, Manray e Womack, para estrelar seu Mantan: The New Millennium Minstrel Show. Quando chega A Hora do Show, no entanto, a audiência adora o programa: era justamente o que seu criador menos queria. Mas nem todos estão satisfeitos. $\mathrm{O}$ irmão de uma das assistentes de Pierre é um terrorista e ativista político. Ele se intitula "Big Black Africa" e resolve tomar uma atitude a respeito."

***

Mensagem 1292

De: E. O. C. C.

Data: Ter Ago 21, 2001 10:29 am

Assunto: I Have a Dream - ouca e veja

Voce pode ouvir (mp3) e ver o discurso "I Have a Dream" de Martin LutherKing no site

http://www.wakeamerica.com/past/speeches/1960/mking_082863.html.

In English, naturally...

E. C.

$* * *$

Mensagem 1294

De: E. O. C. C.

Data: Ter Ago 21, 2001 11:33 am

Assunto: RE: [edutec] I Have a Dream - ouca e veja

Baixei o arquivo mp3 do "I Have a Dream" para a minha maquina e o estou ouvindo. E' de ficar arrepiado. Quando se trata de mexer com as emocoes, a voz humana $e^{\prime}$ instrumento mais adequado do que o texto... Incomparavelmente mais eficaz.

E. C.

$* * *$

Mensagem1311

De: J. R. P.

Data: Ter Ago 21, 2001 6:25 pm

Assunto: Re: [esc2k] Martin Luther King Jr: "Eu tenho um sonho"

T, obigada!

Depois me informarei quando o filme chgará às locadoras.

$\mathrm{J}$.

$* * *$ 
Mensagem 1419

De: J. R. P.

Data: Ter Ago 28, 2001 5:33 pm

Assunto: I HAVE A DREAM

Olá!

Como E. colocou na lista, hoje, o testo "I Have a Dream", está fazendo 38 anos.

Antes da aula de Português, pedi licença ao professor para ler o texto. Antes, porém, expliquei qual era o motivo de estar lendo aquele texto.

Os meninos acharam um pouco grande, mas foi mais um motivo de dabate. Chegamos até na Kan Kus Klan.

Acho que nunca podemos esquecer de lutar pelos nossos sonhos e persistir naquilo que achamos importante nossa vida.

I HAVE MANY DREAMS!

$\mathrm{J}$.

EEFM Estado da Bahia

Crato-Ce

c) a síntese

Como o leitor pode observar, o conteúdo da teia inteira, além de ocupar muito espaço, demanda um tempo de leitura grande. Por isso o conteúdo das mensagens foi lido e sintetizado, como segue:

O ciclo de conversas se inicia a partir de um e-mail no qual seu remetente conta que está escrevendo um livro sobre sonhos e que usa como base de inspiração o discurso "I have a dream" de Martin Luther King, que traduziu e anexou. Isto gera uma série de reflexões sobre liberdade, preconceito e racismo. Retomam-se filmes que tratam destas questões como "Mississipi em chamas" e "Hora do Show".

d) a diagramação

Depois de devidamente estudada, a teia foi diagramada, mantendo-se o número de cada mensagem e o cabeçalho, como segue: 


\section{T e i a 21}

1201 - De: E O C C

Data: Sex Ago 17, 2001 10:58 pm

Assunto: Martin Luther King Jr: "Eu tenho um sonho"

1258 - De: J R P

Data: Seg Ago 20, 2001 5:49 pm

Assunto: Re: [esc2k] Martin Luther King Jr: "Eu tenho um sonho"

1260 - De: O N

Data: Seg Ago 20, 2001 6:01 pm

Assunto: Re: [esc2k] Martin Luther King Jr: "Eu tenho um sonho"

1262 - De: J R P

Data: Seg Ago 20, 2001 6:25 pm

Assunto: Re: [esc2k] Martin Luther King Jr: "Eu tenho um sonho"
1292 - De: E O C C

Data: Ter Ago 21, 2001 10:29 am

Assunto: I Have a Dream - ouca e veja

1294 - De: E O C C

Data: Ter Ago 21, 2001 11:33 am

Assunto: RE: [edutec] I Have a Dream - ouca e veja

1419 - De: J R P

Data: Ter Ago 28, 2001 5:33 pm

Assunto: I HAVE A DREAM
Assunto: Re: [esc2k] Martin Luther King Jr: "Eu tenho um sonho" 
No capítulo 5, explico por meio dos elemento de coesão, como as teias foram diagramadas. Entretanto já antecipo que as mensagens foram agrupadas em seqüência cronológica. Depois da mensagem 1260 há uma ramificação: nas mensagens 1262, 1291 e 1311 há uma discussão sobre filmes que abordam essa questão; nas mensagens 1292, 1294 e 1419 é ressaltada a beleza do discurso.

\section{4 - Assuntos mais freqüentes}

Fiz um levantamento dos assuntos abordados em cada uma dessas conversações. Os assuntos são recorrentes, e por isso agrupei as teias por temas (de -a a g), ou seja, assuntos que motivam discussões.

a) Textos orais (reportagens) e escritos geram temas interessantes para disussão:

2 - Textos sobre curiosidades encontrados em uma lista telefônica;

6 - Uma reportagem da Rede Globo realizada em uma das escolas que participam do projeto do IAS. Também é referida uma reportagem sobre o projeto do IAS publicada pela Revista Isto é ;

9 - Reportagem do programa Fantástico sobre a sucessão de cadeira na Academia Brasileira de Letras, após o falecimento de Jorge Amado;

12 - O ponto de partida para essas mensagens é um texto enviado por um aluno: "frases especiais para serem ditas a pessoas especiais";

21 - O discurso I have a dream, de Martin Luther King;

22 - Manual elaborado por uma escola parceira (Taquatinga/DF), em uma tentativa de esclarecimento à sociedade sobre o procedimento adequado diante de uma pessoa portadora de deficiência auditiva, buscando uma integração entre surdos e ouvintes;

25 - A comunicação da escolha do site de um dos participantes do fórum (EduTec.Net) como "site do mês" por uma revista especializada em educação;

29 - Texto que fala sobre as peculiaridades dos habitantes de Belo Horizonte - MG;

33 - Ciclo de reportagens que foram apresentadas no Jornal Nacional da Rede Globo a respeito do uso da água; 
35 - Condição do negro no ensino superior, principalmente a questão do governo propor cotas especiais para negros nas universidades públicas e de criar cursos prévestibulares específicos para os mesmos;

37 - Nesta teia, são reproduzidas quatro reportagens sobre assuntos diversos.

b) Eventos nas cidades e nas ecolas parceiras:

13 - Criação de uma lista de discussão para a Escola Estado da Bahia, situada no Crato/CE, com o objetivo de tornar possível a solução de dúvidas sobre o projeto do IAS;

18 - Reinauguração das obras do Grande Hotel do Barreiro, em Araxá/MG;

19 - Festival Regional de Cultura Popular em Araxá/MG;

20 - Inauguração de um site sobre Filosofia da Educação;

23 - A informação de que uma escola parceira, o "C.E. Dom Otaviano de Albuquerque" está sob nova direção;

26 - XI Edição do Festival de Dança do SESI - Araxá /MG;

30 - Noticia da rádio comunitária criada em uma escola da participante do fórum;

32 - Nova jornada de um aluno como monitor do laboratório de informática em uma escola perceira;

34 - Início de monitoria de uma aluna no laboratório de informática em que estuda.

c) Encontros presenciais aumentam a interatividade da lista, como o que acontece nas teias:

1 - Encontro no RS e no município de Rio das Ostras/RJ;

3 - Encontro entre as escolas parceiras da $2^{\mathrm{a}}$ edição e algumas escolas parceiras da $1^{\mathrm{a}}$ edição, ocorrido em Fortaleza/CE;

6 - Encontro em Meruoca/CE;

8 - Fórum no município de Matias Barsosa/MG, entre escolas parceiras dos municípios de São Pedro d'Aldeia e Rio das Ostras/RJ e uma escola não parceira, mas próxima da escola sede;

10 - Encontro de algumas escolas do DF;

24 - Um evento, denominado Oficina de Semeio no CEDOA, onde participaram várias escolas. 
d) Problemas locais, gerando reuniões e discussão dos projetos, são temas constantes da lista:

4 - Pedido de sugestões de uma professora de uma escola situada na cidade do Crato/CE, sobre uma oficina que os alunos farão para a comunidade local;

7 - Discussão sobre o problema da depredação das escolas (carteiras, banheiros, etc.), procurando meios para resolver ou amenizar o problema, ou até mesmo evitá-lo;

11 - Discussão sobre dois projetos semelhantes: "O lago azul pede socorro", do Colégio Padre Cláudio Morelli, e a preservação do rio Uruaí, do CEDOA;

27 - Pedido de auxílio de uma das participantes do fórum para o desenvolvimento do projeto de dois jornais em sua escola: um geral e outro ecológico.

e) Datas comemorativas:

31 - Congratulações pelo dia do estudante;

36 - Congratulações pelo dia dos pais;

f) Palestras:

17 - Ciclo de palestras a respeito de educação à distância e tecnologia, organizado pela Unicamp;

28 - Palestra de uma aluna sobre formação de grêmio e Protagonismo Juvenil na EEFM José Alves de Figueredo, no Crato-CE.

g) Outros:

5 - Mensagens de apresentação pessoal de novos assinantes gerando mensagens de boas vindas pelos veteranos da lista;

14 - Relato de uma das participantes, dizendo como conheceu o amor de sua vida;

15 - Informe do IAS aos assinantes de que a Microtec acabara de enviar a última lista das escolas que tiveram os laboratórios instalados;

16 - Discussão de problemas técnicos do sistema: as mensagens estão com data errada. 
3.5 - Início, fim e duração das teias

Nesse item mostro e comento como as teias se iniciam, terminam e faço um levantamento do período de duração das conversas e dou alguns exemplos.

\subsection{1 - Como as teias se iniciam}

Em geral, uma teia se inicia com uma mensagem enviada por um dos participantes do fórum. A única exceção foi a teia número 1, cujas mensagens tiveram 2 pontos de partida, como já foi esclarecido no item 3.3. Essa teia, pela sua relevância, também foi estudada no capítulo 5, onde se observam elementos coesivos.

Há um fator importante para o início de algumas teias, que são os encontros presenciais que aconteceram nesse período, aumentando muito a interatividade do grupo, como acontece em 6 teias, com já mostrado no item 3.4 - c. Nesses casos, as mensagens que iniciam as teias são mensagens com objetivo de organizar o evento. Vejamos o exemplo da teia 3: "Fortaleza" (cf anexo p. 151-154).

Quem inicia a teia é O.N., membro da equipe técnica do IAS. Reproduzo um fragmento da mensagem inicial dessa teia; M-679.

Caras escolas parceiras,

O Programa Sua Escola foi convidado a participar de um painel no XXI Congresso Anual sobre tecnologia da informação e a questão social. Este congresso é organizado pela Sociedade Brasileira de Computação (SBC) e será realizado em Fortaleza (CE) entre os dias 30 de julho a 03 de agosto de 2001.

O Programa Sua Escola vai organizar e participar da apresentação no dia 1 de agosto (quarta-feira), sobre o tema da informática educativa e das novas formas de ensinar e aprender como fatores de promoção da cidadania de crianças e jovens. Durante o período da manhã serão apresentados o Instituto Ayrton Senna e o Programa Sua Escola a 2000 por Hora.

$\mathrm{Na}$ parte da tarde algumas escolas parceiras vão fazer uma apresentação contando sobre o desenvolvimento de seus projetos, suas conquistas e desafios. Estamos convidando as seguintes escolas:

Escola (...)

Além destas escolas, também estão sendo convidadas todas as escolas do Ceará.

Para estes eventos procuramos dar oportunidades para diferentes escolas a participar. No futuro estaremos convidando outras escolas a participar de encontros. 
A importância de participar de eventos como este está na possibilidade de refletir sobre nossas ações e conquistas, além da oportunidade de mostrar a outras pessoas as coisas que estão acontecendo dentro das escolas. Se vocês souberem de eventos ou seminários deste tipo, que tratem de tecnologia e educação e que vocês achem interessante participar, traga o assunto para a lista.

Abraços,

A., C. e T.

Entre os emissores, percebi que houve uma assimetria em relação aos que iniciaram teias. Das 37 teias, 12 foram iniciadas por assinantes que pertenciam à Equipe Técnica (funcionários do próprio Instituto Ayrton Senna) ou da Equipe Gestora (pessoas contratadas pelo Instituto como consultores); 25 foram iniciadas por assinantes pertencentes às escolas parceiras, sendo que dessas, 14 foram iniciadas por professores e 11 por alunos.

Quanto aos alunos, ocorreu um fato curioso. Das 11 teias, 7 foram iniciadas por uma aluna, na época estudante do Ensino Médio: JRP. A participação dela foi tão intensa nesse período que vale a pena certos comentários.

A teia 2, "Curiosidades" foi não só inciciada (M857), como conduzida por ela, pois as mensagens 858 - Curiosidades 1-2-3, 882 - Curiosidades 4-5-6, 940 - Curiosidades 7-8-9,... 1945 - 52-53-54, que dão início a 8 fios, enviadas por ela. Do total de 114 mensagens dessa teia, 30 são dela. Nessa conversa participaram 19 assinantes. Ela contribuiu com $26 \%$ da teia.

$\mathrm{Na}$ teia 6, "Estamos famosos", também iniciada por ela (M 1420), com 16 participantes e 30 mensagens, ela contribui também com $26 \%$ ( 8 mensagens).

Outro fator importante é que ela é parte do assunto dessa conversa, pois a escola em que a mesma estudava estava em uma reportagem. Reproduzo a mensagem 1420:

Oi, pessoal!

Hoje, pela manhã, um repórter da TV Verdes Mares - a filial da Rde Globo no Ceará - veio fazer uma reportagem com a gente no laboratório.

Não ficamos muito à vontades, por que é uma coisa muito ensaiadinha.

Todo mundo falou um pouco sobre o que estava fazendo, os projeto que desenvolvia com o uso dos computadores.

Alguns dias atrás, o mesmo repórter, veio só marcar o dia e conversou comigo e com F.L.J.. Falamos sobre tudo, incluissive sobre a lista.

Quando ele chegou para falar comigo perguntou o que estava fazendo, e eu respondi que estava mandando algumas mensagens para a lista. Saiu perguntando quem eram as pessoas que participavam, os estados... Até que perguntou sobre o que a gente discutia, então eu falei vários assuntos, dentre eles Filosofia. Para que falar em Filosofia. Ele ficou doido, disse que queria fazer uma reportagem comigo falando sobre porque discutir filosofia, qual a importância dela. 
E.C. só não citei teu nome, mas logo no início ele saiu alarmou que estávamos discutindo Filosofia com um filósofo de São Paulo. Mas acho que não falie muita besteira. :o)))

Abraços...

$\mathrm{J}$.

EEFM Estado da Bahia

Crato-ce

Também reproduzo a mensagem resposta (M 1421) em que o filósofo de São Paulo, ao qual ela se refere na M-1420, ainda informa que o nome dela tinha sido mencionado na Revista Isto É daquela semana:

É isso aí, J.! Além de ter o nome mencionado na Isto É desta semana, agora você vai aparecer na Globo!!!

Tenho certeza de que não falou nenhuma besteira filosófica, não! Vá em frente, Ju, que o mundo é seu.

E. C.

Ela também é o assunto da teia 28: "Palestra da J.R.P. no Crato". Essa teia tem 8 mensagens e 4 participantes. Ela contribuiu com 50\% (4 mensagens). Reproduzo a mensagem inicial 1363:

Oi, pessoal!

Ontem, eu, L. e A. - estes dois últimos membros do grêmio - fomos convidaos para dar uma palestra na EEFM José Alves de Figueredo, aqui em Crato.

Fomos acompanhados por G., coordenadora de gestão, que já tinha ido lá falar sobre como eles poderiam formar um grêmio.

Eu comecei falando sobre protagonismo juvenil, usei umas transparências para ilustrar a apresentação. Levamos o reto progetor da escola e quase passamos um vechame! Não estávamos conseguindo ligar, imaginem as nossas caras diante de vários alunos, tentando achar o buraquinho do parafuso. :o)))

Os meninos - Alan e Luciana - falaram sobre a participação , dentre outras atividades desenvolvidas por um gremista.

Estavam lá,assistindo nossa palestra, quatro alunos do curso de Pedagogia da URCA. Estavam estagiamdo na escola, dentro da áres de Gestão, e um dos requisitos exigidos seria a formação de grêmios. Logo depois marcamos um encontros com eles para que possam vir visitar a escola, conhecer nosso trabalho e adquirir material para ajudar na finalização de seu estágio.

Acho que foi muito legal, o pessoal pareceu bem empolgado. Já é a $3^{\circ}$ vez que escolas de outros polos, nos convida para dar esse tipo de palestra. Nossentimos úteis. 


\section{Beijos \\ $\mathrm{J}$. \\ EEFM Estado da Bahia \\ Crato-ce}

A participação dessa aluna foi tão importante, que em 2003 ela passou a ser Agente Técnica Júnior do IAS (cf item 1.3.7, p.35).

\subsection{2 - Como as teias terminam}

As teias terminam porque o assunto foi solucionado ou porque o assunto esgotou-se. Como as teias vão se renovando, um assunto vai sendo substituído por outro. Geralmente, quando houve encontros presenciais, as últimas mensagens da teia são de avaliação do encontro. Vejamos alguns exemplos:

a) Escolho a teia 3 "Fortaleza", pois o início já foi mencionado no item 3.5.1. Depois de algumas mensagens em que os participantes narram o encontro, vem um fio com as últimas mensagens da teia, em uma tentativa de fechamento, que é a avaliação. Reproduzo o fio (cf anexo p. 151-154):

\section{Te i a 3 ( f i o )}

1271: De: C.

Data: Seg Ago 20, 2001 9:40 pm

Assunto: Re: [esc2k] Porta voz: avaliação de Fortaleza
1195: De: G. L. S.

Data: Sex Ago 17, 2001 8:31 pm

Assunto: Porta voz: avaliação de Fortaleza

1214: De: S.e L.

Data: Sáb Ago 18, 2001 10:12 pm

Assunto: Re: [esc2k] Porta voz: avaliação de

Fortaleza

1219 : De: A.P.

Data: Dom Ago 19, 2001 10:37 am

Assunto: Avaliando Fortaleza

1220 : De: E. O. C. C.

Data: Dom Ago 19, 2001 11:20 am

Assunto: RE: [esc2k] Avaliando Fortaleza 
Em seguida, vejamos os textos:

\section{Mensagem 1195}

Voltei hoje de uma visita às escolas de Tocantins. Lá, eu reencontrei a profa.Adriana, daescola Rui Brasil Cavalcante, que me perguntou sobre uma avaliação da ida ao congresso em Fortaleza. ela havia relacionado uma série de pontos positivos, e gostaria de deflagrar uma avaliação coletiva. Mas, ela não tem acesso á Internet ainda. Então, ela me pediu para dizer a todos que, do ponto de vista dela, fui super válido, especialmete por ter podido perceber que o programa é uma construção coletiva, que as escolas podem se entre-ajudar, que muitas coisas desprezadas no movimento de sua escola pode ser considerada com um avanço significativo. Agluém mais se posiciona com relação a nossa participação no congresso da sociedade brasileira de computação, em Fortaleza?

Saudações,

G.

Orientador - Tocantins

$* * *$

Mensagem 1214

Oi G.,

Concordo com a professora Ad. de Tocantins. Realmente o Congresso foi muito válido, mas faltou uma avaliação coletiva.

Será que ainda dá tempo? Alguma coisa mudou nas escolas depois do nosso encontro?

Não houve muitos comentários depois de nosso regresso às escolas.

Acho que é importante retomarmos esse assunto, você concorda também C?

Abraços

S. - Araxá

$* * *$

Mensagem 1219

Olá, pessoal!

Enquanto finalizávamos as atividades em Fortaleza, comentamos sobre o quanto havíamos vivenciado juntos, nos dias de SBC.

Com algumas pessoas eu mesma cheguei a dizer que seria importante e necessário retomar algumas questões e propor uma avaliação.

Acho que falamos superficialmente sobre algumas coisas...

Comentamos algumas impressões...

Compartilhamos algumas idéias, mas não ficamos com o compromisso oficial de tratar da avaliação daquele encontro.

Confesso que iniciei este esboço, mas outras coisas acabaram "atropelando" a idéia e ela ficou aqui, "na estante"... mas não ficou esquecida...

Mas eis que a necessidade surge de vocês, que nos apontam esta lacuna e propõem um momento de avaliação.

QUE LEGAL!!! 
Para encaminhar um pouco a proposta, aqui vão algumas sugestões, que vocês podem ir "adequando", da maneira que facilitar o trabalho da escola.

1. O melhor lugar para a avaliação pode ser a própria lista.

2. Alguns pontos que podem facilitar a organização dos comentários:

- O evento como um todo;

- O contato com as escolas de uma maneira geral;

- A apresentação do Programa "Sua Escola a 2000 por Hora" como um todo;

- A participação de cada escola;

- A visão de cada um sobre a diversidade de projetos, de estrutura de apresentação, de forma e conteúdo de apresentações;

- Nós e a tecnologia: venturas e desventuras das ferramentas que estavam a nosso dispor ;o))) ;

- O trabalho na biblioteca virtual;

- Antes e depois de Fortaleza: O que mudou? O que ajudamos a mudar?

Bem...

Alunos e professores presentes podem imaginar a melhor forma de organizar esta mensagem...

Talvez algumas questões possam migrar para listas específicas, depois que detonarmos as primeiras mensagens... mas isso a gente vai precisar esperar.

Pediria aos orientadores que nos ajudassem no sentido de fazer a "ponte" com aquelas escolas que ainda não estão com a Internet instalada, ok?

Será que conseguimos enviar as mensagens das escolas até o fim do mês?

Régia, será que você consegue contato com as escolas do Ceará, parceiras da Seduc?

Vamos lá, pessoal!

E, antecipadamente, agradeço aos professores que tomaram a iniciativa de retomar este assunto!!!!

Valeu, valeu, valeu!!!

Beijocas!

Drip

Orientadora RJ-PR

(grifos meus)

$* * *$

Mensagem 1220

Seria bom que, nesse processo de avaliacao, tivessemos nao apenas os pontos de vista daqueles que sao "macacos velhos" nesse tipo de encontro, mas tambem, e, talvez, prioritariamente, daqueles que pela primeira vez participaram desse tipo de evento.

Os "veteranos" podem cair na tentacao de comparar um evento com outro em vez de focar na especificidade e unicidade do encontro em questao - algo que os "calouros" podem captar melhor...

E. C.

(grifos meus)

$* * *$

Mensagem 1271

Claro que concordo S.!

Acho que sempre bom discutirmos algo que nos trouxe 
novas experiêcias!

C. - Araxá

O importante em focalizar nesse fio é o fato de a lista ser um veículo para que a avaliação aconteça. O fato de existirem teias regionais, pode fazer com que a "conversa" migre para outro lugar, com as especificidades de cada região. Há uma tentativa de "não interferir" no processo avaliativo, proposta por um membro da equipe gestora.

\subsection{3 - Duração das conversas}

O levantamento do tempo de duração das teias mais longas e mais curtas trouxe as seguintes informações:

a) as teias mais longas

\begin{tabular}{|r|r|l|l|r|}
\hline \multicolumn{5}{|c|}{ AS 10 TEIAS MAIS LONGAS } \\
\hline $\begin{array}{r}\mathrm{N}^{\mathrm{o}} \text { de } \\
\text { ordem }\end{array}$ & $\begin{array}{l}\mathrm{N}^{\mathrm{o}} \text { da } \\
\text { teia }\end{array}$ & $\begin{array}{l}\text { No de } \\
\text { mensagens }\end{array}$ & $\begin{array}{l}\text { No de } \\
\text { participantes }\end{array}$ & Duração (dias) \\
\hline 1 & 2 & 114 & 19 & 85 \\
\hline 2 & 1 & 115 & 39 & 83 \\
\hline 3 & 4 & 58 & 19 & 66 \\
\hline 4 & 13 & 14 & 8 & 48 \\
\hline 5 & 3 & 68 & 20 & 35 \\
\hline 6 & 15 & 10 & 3 & 30 \\
\hline 7 & 6 & 31 & 16 & 29 \\
\hline 8 & 11 & 16 & 8 & 16 \\
\hline 9 & 22 & 9 & 3 & 15 \\
\hline 10 & 12 & 15 & 9 & \\
\hline
\end{tabular}

Não se comprovou uma tendência para que uma teia de maior duração tenha o maior número de participantes e, consequentemente, o maior número de mensagens. As discrepâncias são grandes: as mensagens variam de 9 a 115; o número de participantes varia 
de 3 a 39 e o tempo de duração da conversa de 15 a 85 dias. O que levaria 3 participantes demorarem 32 dias para finalizar uma conversa? (Teia 15), e também 3 participantes demorarem 16 dias para finalizar outra conversa? (Teia 22).

a) exemplo 1:

No caso da teia 15 (cf anexo, p. 174), cujo título é "instalação do laboratório", reproduzo parte da mensagem inicial (M-1070):

Ola pessoal,

Ontem aa noite a Microtec nos enviou a ultima tabela de instalacao doslaboratorios. Tivemos um avanco desde o dia 20 de julho.

Abaixo seguem todas as informacoes por escola. Peco para que voces me avisem caso alguma informacao nao esteja correta. Gostaria de saber tambem se voces ja receberam as licencas de uso do Office porque a Microtec confirmou que todas ja foram enviadas.

Peco aos orientadores que verifiquem a situacao das escolas que orienta neste email e me avisem caso nao corresponda aa real situacao na escola, o mais rapido possivel.

Abracos a todos,

C.

Instituto Ayrton Senna

(...)

A mensagem, iniciada por uma integrante da Equipe Técnica do IAS, prossegue com a relação das escolas, cujos laboratórios de informática já foram instalados. Ela também menciona o nome de algumas escolas cujos laboratórios estão em fase de instalação e discute algumas pendências. Quatro dias depois, a mesma assinante envia outra mensagem com mais informações e lembra ao grupo de que em julho uma carta havia sido enviada pelo correio com informações sobre o acesso à internet. Também pede os recibos para que o IAS possa efetuar o pagamento. As questões que C.Z. levanta devem ser resolvidas pelos diretores das respectivas escolas, talvez por isso haja a baixa interatividade, além do fato de a maioria das escolas já estarem com os respectivos laboratórios de informática instalados.

Acredito que a teia 15 se diferencia das demais por tratar de um assunto muito específico, que não envolve a maioria das escolas, pois já estavam com o laboratório instalado. Como ficará claro no item 4.2, entendo essa teia como exemplo de "uma conversa descontinuada", pois nesse caso a conversação não é a principal atividade, mas está subordinada à outra atividade, obrigação profissional, já que C.Z., que inicia e conduz a teia, contribui com 7 de 10 mensagens. 
b) exemplo 2:

A teia 22 (cf anexo, p.184) aborda questões relativas a surdez e é iniciada por M.R.C., professor surdo da Escola Normal de Taquatinga/DF (pertencente à $2^{\mathrm{a}}$ edição do concurso) e único surdo participante da lista. Cabe lembrar que na $1^{\mathrm{a}}$ edição do concurso, duas escolas vencedoras, uma de Charqueadas/RS e outra de Ceilândia/DF apresentaram projetos relacionados à surdez.

Pelas mensagens enviadas à lista geral há a impressão de que o contato entre membros dessas três escolas não ocorria, como aparece na mensagem 1024, enviada po M.V.B. e dirigida a M. e retomada com acréscimo de informações por G.L.S. na mensagem 1039. Ambas pertencem à teia 1 (cf anexo p.142-146):

Olá R.

Acho uma excelente idéia que o pessoal de Charqueadas volte a participar. O contato entre os grupos de surdos (Charqueadas, Brasília, ...) via Internet, continua sendouma meta a ser atingida e, tenho certeza, que a tua ajuda neste processo é fundamental.

Lamento não poder te acompanhar no dia 17/08 pois já tenho compromisso agendado com um grupo de alunos que oriento.

(...)

Abraços,

M. (M-1039, Teia 1)

$* * *$

Marcus,

Voce evidencia para o Ricardo que a retomada dos contatos entre Charqueadas e Ceilandia é importante e continua sendo uma meta importante. Concordo plenamente com você e incluo a Escola Normal de Taguatinga, uma das raras escolas brasileiras que forma professores surdos.

Saudações,

G. (M-1039, Teia 1)

Essa questão também é abordada na teia 22. Um integrante da Equipe Gestora do IAS, N. M., pede para que M.R.C. tente trazer mais surdos para a comunidade da lista. Reproduzo a mensagem 1034:

Olá, M.!

Realmente, é muito bom, para todos nós, conseguirmos nos comunicar com a comunidade dos surdos. Agora, tenho um desafio para você... Que tal tentar trazer outros alunos para a lista? A L. me falou que há uma moçada super esperta por aí... E não adianta me enganar: ela me contou que cada um fala mais do que o outro... 
Timidez é palavra que não existe no dicionário de vocês. Hehehehehe... Portanto, mãos à obra: traz o pessoal para nós conhecermos!!!

Um abraço,

N. M.

Orientador - MG

Acredito que a teia 22 possui a mesma característica da teia 15 , tratar de um assunto bastante específico, já que apenas três escolas desenvolviam projetos sobre surdez. O tempo de demora dessa conversa pode ser entendida pelo exemplo que Marccocia (2004), baseandose em Goffman chama de "estado interativo aberto", já que os assinantes podem participar da conversa em curso a qualquer momento. Assim a organização do diálogo acontece por meio de uma temporalidade dilatada (cf 4.4, p. 97)

b) as teias mais curtas

\begin{tabular}{|c|c|c|c|c|}
\hline \multicolumn{5}{|c|}{ AS 10 TEIAS MAIS CURTAS } \\
\hline $\begin{array}{l}\mathrm{N}^{\mathrm{o}} \mathrm{de} \\
\text { ordem }\end{array}$ & $\begin{array}{ll}\mathrm{N}^{\mathrm{o}} \mathrm{da} \\
\text { teia }\end{array}$ & $\begin{array}{l}\mathrm{N}^{\mathrm{o}} \text { de } \\
\text { mensagens }\end{array}$ & $\begin{array}{l}\mathrm{N}^{\mathrm{o}} \text { de } \\
\text { participantes }\end{array}$ & Duração (dias) \\
\hline 1 & 32 & 6 & 5 & 1 \\
\hline 2 & 28 & 8 & 5 & 2 \\
\hline 3 & 25 & 9 & 5 & 2 \\
\hline 4 & 26 & 9 & 5 & 2 \\
\hline 5 & 24 & 9 & 6 & 2 \\
\hline 6 & 34 & 5 & 5 & 3 \\
\hline 7 & 35 & 5 & 4 & 3 \\
\hline 8 & 23 & 9 & 7 & 3 \\
\hline 9 & 16 & 11 & 6 & 3 \\
\hline 10 & 33 & 6 & 5 & 4 \\
\hline
\end{tabular}

Ao contrário das teias mais longas, as teias mais curtas mostram-se bastante homogêneas: a duração das conversas varia de 1 a 4 dias; o número de participantes varia de 4 a 7 pessoas e as mensagens variam de 6 a 11 .

Acredito que esse aspecto também pode ser entendido pelos assuntos abordados e, por isso, destaco 3 teias para comentar - 16, 23 e 26: 
a) exemplo 1

A teia 16 (cf anexo, p. 175), cujo título é "data das mensagens do Crato", e iniciada por E.O.C.C. com a M-827, diz respeito a um problema técnico: os relógios dos computadores do laboratório de informática da EEFM Estado da Bahia, localizada em Crato/CE, estão com data alterada. Reproduzo também a M-831, enviada por M.P. do RS, na qual informa como fazer a mudança de horário nos relógios dos computadores.

M. e F.

Suas mensagens estao chegando aqui com datas erradas: as duas da F. com data de 22/1/2000 e as varias da M. com data de 22 e 23/4/2001. Quase nao as vi -- ficaram escondidas la' atras...

E' bom dar uma verificada nas datas dos computadores do Laboratorio ai' no Crato... OK?

Beijos.

E. C.

$* * *$

$>$ M. e F.

$>$ Suas mensagens estao chegando aqui com datas erradas Não quero dizer com esta mansagem que não saibam corrigir o erro, mas como o Porf. E. citou ai vai o passo a passo para arrumar o erro:

$1^{\circ}$ Localize o relógio que aparece no canto inferior de seu monitor.

$2^{\circ}$ De dois cliques e logo aparecerá uma nova janela e ali você poderá corrigir a data errada e arrumar o que estiver errado.

$3^{\circ}$ não tem mistério é só clicar com o mouse encima do dia correto, ajustar o ano bem acima e a hora ao lado.

Qualquer coisa estou a disposição( nova forma de ajuda como comentou o prof. Eduardo chaves é o EAD)

Beijos Faustina e Marilac e a todo pessoal de Crato milhões de Abraços.

Como se pode perceber, o conteúdo é específico dessa escola, embora outras pessoas participem tentando ajudar a resolver o problema.

b) exemplo 2

A teia 23 (cf anexo, p. 185) traz como assunto a mudança de diretor no C.E. Dom Otaviano de Albuquerque, escola situada no município de Campos/RJ. Reproduzo a mensagem inicial 1203, enviada por N. M. P., em nome de todos os integrantes do CEDOA, e a mensagem 1204, enviada por N.M., integrante da Equipe Gestora e responsável pelas escolas de Minas Gerais. 
M 1203

Oi, pessoal,

Queremos comunicar a todos que nossa escola a partir de hoje tem uma nova Direção, E. M. e N.

Estamos muito felizes! Elas são muito capacitadas, acreditam numa Educação para a vida e cidadania. Sào de Ururaí, têm uma história de participação comunitária, são respeitadas e queridas.

Um beijão para vocês.

Todos do

C.E.Dom Otaviano de Albuquerque

***

M 1204

Olá, pessoal do Dom Otaviano de Albuquerque,

Desejo às novas diretoras E. M. e N. o maior sucesso em seu novo trabalho. Com essa referência inicial, já dá para imaginar o empenho que vocês terão na construção de uma escola "a 2000 por hora". Contem conosco para o que precisarem. Nossa comunidade virtual (e real!) está sempre disposta a colaborar. Sejam bem-vindas.

Um grande abraço,

N. M.

Orientador - MG

Como se pode perceber o assunto é específico dessa escola em particular. Só cabe aos demais integrantes da lista enviarem mensagens de congratulações e de apoio, como acontece na M-1204.

c) exemplo 3

A teia 26 (cf anexo, p. 186), cujo assunto é "Festsesi - Araxá", é iniciada por Cin. em 30 de agosto de 2001, convidando todo o pessoal da lista a participar desse festival de dança. Reproduzo as mensagens 1485 e 1492

Oi pessoal!

Quero através deste fazer um convite extensivo a todos. Nos dias 02/09 à 09/09 estará acontecento a XI Edição do Festival de Dança do SESI - Araxá. É uma mostra de dança que o SESI promove já a 11 anos. É muito lindo! Tem apresentações de danças do clássico à dança de rua. Há apresentações em várias localidades da cidade como: praças, mineradoras, escolas, casas assistenciais,e esse ano, terá uma apresentação da bailarina Ana Botafogo em uma noite de gala no Grande Hotel do Barreiro.Todas as noites tem apresentações especias em um Ginásio daCidade. 
E claro! Nossa escola não vai ficar de fora! Já a uns 3 anos que acontece uma apresentação especial em nossa escola, e esse ano não será diferente. Nossa escola também aloja alguns bailarinos do festival.

Vale a pena conferir!

Abração!

Cin.

$* * *$

Gente,

Vamos fretar um ônibus e vamos para Araxá? Esse evento promete, de fato, ser lindo!

Um abraço,

N. M.

Eventos em cidades geralmente produzem teias bastante interativas. Entretanto, o convite para o festival foi enviado em 30/08 e o evento se iniciava em $02 / 09$, não permitindo muita discussão. Talvez esse seja o motivo para que essa conversa tenha durado apenas 3 dias. 


\section{4 - A LISTA ESC 2K E A NOÇÃO DE CONVERSAÇÃO ELETRÔNICA}

4.1 - Interação em uma comunidade delimitada

A lista Esc 2k constitui-se em uma comunidade simples e bem definida. Há um sentimento de pertença, demonstrado por M.R.C. nas mensagens enviadas para a lista (cf item 1.3.7, p 35), onde ele se refere ao "Programa sua escola a 2000 por hora" como sua família. McCleary (1996: 209) na esteira de Swales, classifica a lista MBU-L (seu objeto de estudo), como "comunidade de discurso" e afirma que a preocupação de seus membros não se restringem aos objetivos públicos da lista, mas são marcados pela "socialização e solidariedade."

$\mathrm{O}$ autor exemplifica, dizendo que em episódios esporádicos onde duas pessoas se comunicam, essa dupla não constitui uma comunidade. O autor ainda afirma que "a CMC é capaz de fornecer um modelo e um suporte técnico para o desenvolvimento de uma concepção de comunicação ao mesmo tempo mais completa e suficientemente delimitada que serve para a construção de teorias" (1996:202).

Um outro aspecto relevante nesse tipo de comunicação, apontado pelo autor, é o de que a comunicação de muitos para muitos (o autor não usa o termo polílogo) é comunitária. Em seguida, conceituo polílogo.

\section{2 - Interação polilógica}

Fávero e Aquino (2002:159) afirmam que os estudos sobre a interação elaborados no quadro da Análise da Conversação têm priorizado as trocas diádicas. ${ }^{50}$ Entretanto, percebemos em nossas relações sociais situações interativas compostas por múltiplos participantes: reuniões em família, relações dentro de uma sala de aula e nos locais de trabalho etc. Ao analisarmos o contexto social em que os processos interacionais ocorrem, as trocas diádicas são minoria.

Kerbrat-Orecchioni (2004:3) define uma interação polilógica como uma atividade discursiva que envolve diversos interlocutores. Etimologicamente, o termo deriva do prefixo

\footnotetext{
${ }^{50}$ Kerbrat-Orecchioni (2004:1) explica uma certa confusão que as pessoas fazem ao usar os prefixos dia- e di- . $\mathrm{Na}$ Grécia clássica, dia- significa "por meio de", e não "dois" como muitos pensam. Para evitar ambigüidade, a autora opta por "dílogo" ao se referir às trocas entre duas pessoas.
} 
poli- indicativo de "vários, muitos". A autora considera o termo apropriado, pois marca um paradigma coerente, tal como: "dílogo", "trílogo", "tetrálogo" etc. O polílogo ${ }^{51}$ assume diversas configurações, uma vez que compreende a participação de no mínimo três participantes até, teoricamente, um número incontável de pessoas. Em virtude do trílogo ter sido objeto de análise da autora anteriormente, ela definirá como objeto de estudo, as interações verbais que excedam a tríade de participantes.

A autora reconhece que uma situação polilógica é estrutural e organizacionalmente muito próxima à situação triádica. Entretanto, as dificuldades de interação e os problemas de construção textual tendem a ser potencializados cada vez que a situação envolve um número maior de interlocutores.

Nas conversações naturais face a face, ao aumentar-se o número de participantes, observa-se que o processo de negociação entre os falantes revela-se mais complicado e o revezamento de papéis entre falante e ouvinte, por vezes, não é claro; a alternância de turnos tende a não obedecer a regras específicas, sendo comum a violação das regras de seleção dos falantes (assaltos, truncamentos, passagens sem consentimento ou inobservância de lugares relevantes para transição); a sobreposição de vozes é recorrente; a construção textual está mais sujeita a digressões e truncamento de idéias; prevalece a condição assimétrica do discurso, com risco de alguns participantes serem deixados de lado em alguns momentos da interação, em virtude da coalizão constituída por outros.

Em vista disso, as conversações compostas por múltiplos participantes mostram-se mais conflituosas, já que estão mais expostas às violações de regras do sistema conversacional estabelecido pelas relações diádicas.

Apesar das constantes subversões do esquema de funcionamento de turnos e do truncamento e digressão de tópicos, os participantes, em interações polilógicas, sentem mais diluída sua obrigação de cooperar na construção do discurso.

Para os estudiosos da análise conversacional, analisar o funcionamento dos polílogos apresenta-se como tarefa mais complicada que o estudo dos trílogos e, por conseguinte, dos dílogos. A complexidade é, obviamente, oriunda do maior número de participantes. Nesse

\footnotetext{
${ }^{51}$ Cabe comentar que há certa mudança de terminologia em textos da mesma autora. No artigo de 2004, aparecem polylogue e trilogue e no livro, cuja tradução é de 2006, os termos são "triálogo" e "poliálogo" (p. 26).
} 
sentido, com relação aos interlocutores que participam da situação polilógica, quanto maior seu número, mais delicada configura-se a atividade conversacional.

Como o objetivo de nosso trabalho é analisar as interações complexas, com pelo menos três participantes, fiz um outro recorte no corpus, diagramando teias com pelo menos cinco mensagens, que receberam números de 1 a 37 , para que pudessem ser estudadas mais profundamente. As teias de números 20 e 37, com apenas dois participantes cada, foram desconsideradas. Também as teias formadas por 1, 2, 3 e 4 mensagens (por causa do baixo índice de interação), e que somadas perfazem um total de 105 pequenas teias, foram desconsideradas no estudo.

Dessa maneira, tecerei algumas considerações sobre dados e elementos organizacionais da conversação natural e posteriormente verificarei como aparecem na conversação eletrônica polilógica.

\section{3 - A noção de conversação natural}

Inicio com a definição de Marcuschi (2006:88) sobre conversação natural:

É aquela que se dá espontânea e livremente no dia-a-dia, sem qualquer tipo de imposição institucional ou por força de alguma situação, como as entrevistas, os inquéritos, os diálogos em filmes, teatros, novelas de TV e similares. Geralmente se dá face a face, mas pode ocorrer por meios eletrônicos, como o telefone, o rádio e a televisão.

O autor já assinala que nem sempre a conversação acontece face a face, pois ela também pode ocorrer e que ela também pode ocorrer nos meios eletrônicos. O autor não fala das mídias digitais (o texto original é de 1986) e não era essa uma preocupação daquela época. Entretanto, em obra de sua organização, em parceria com Xavier, preocupa-se com a noção de gênero, no que chama de "discurso eletrônico" (2004:14). O livro, dividido em artigos, aborda vários aspectos de CMC.

Uma outra característica da conversação natural é a noção de turno. Aqui recorro a Urbano (2000:91), pois o conceito de turno nesse livro me parece mais completa. O autor define turno ${ }^{52}$ juntamente com par conversacional:

\footnotetext{
52 Contribuição importante é feita por Galembeck (1993:61-63) a respeito da tipologia dos turnos: nuclear (com valor referencial) e inserido (indica que o interlocutor "acompanha" ou "segue" as palavras do seu interlocutor).
} 
Nas formas de interação alternantes e sucessivas, os participantes se revezam em sua qualidade de agentes das ações consecutivas. Denomina-se turno a unidade estrutural que se define como aquela em que um falante diz alguma coisa durante uma abordagem interativa continuada.

Para que se concretize uma conversação como tal, ou a própria linguagem, não basta a ocorrência de um turno, mas sim, no mínimo, a ocorrência (relevância condicional), que significa que, dada a primeira parte somada à segunda, ou seja, um par conversacional, é considerada, na realidade, a unidade conversacional mínima. Pergunta e resposta constituem, juntas, exemplo típico de um par conversacional, mas também convite/aceitação, convite/recusa, acusação/defesa, ordem/execução etc.

Quando esses turnos estão imediatamente seguidos, contíguos, constituem um par adjacente.

Percebe-se que na conversação eletrônica não há alternância (no sentido de falar um por vez) e a troca de falantes apresenta-se de forma mais complexa. Os pares adjacentes não se apresentam contíguos e para uma pergunta surgem freqüentemente mais de uma resposta, não se constituindo por pares.

Um elemento importante da conversação é o tópico discursivo, pois como lembra Marcuschi (2006:75) "uma conversação não é um enfileirado aleatório e sucessivo de turnos". Toda conversação, como observa Kerbrat-Orecchioni (2006:13) segue algumas regras de produção, mesmo aquelas que nos parecem mais anárquicas.

Fávero (1993:38), na esteira de Brown e Yule, afirma que tópico pode ser entendido como aquilo acerca do que se está falando. Urbano (2000:93-94) lembra que essa é uma unidade pré-teórica. Todo texto conversacional é formado por porções tópicas, que estão subordinadas de forma hierárquica a uma estrutura global em um plano vertical. Nesse plano reorganizam-se pequenas estruturas, chamadas subtópicos, que estão no mesmo tópico.

A divisão do fluxo conversacional do nosso subcorpus foi feita dessa maneira, agregando todas as mensagens relacionadas a um mesmo tópico, formando 37 teias. Esse assunto será retomado no capítlo 5, quando exemplificarei como as teias se constroem.

Nesse aspecto, é interessante a observação de Urbano (2000:94) quando afirma que o tópico conversacional não se limita a um único turno, pois os participantes possuem uma preocupação de manterem a conversação centralizada e usam referentes, produzindo vários turnos. Esses turnos tratam de um mesmo tópico conversacional.

Outra observação importante é a de que o tópico se apresenta como um conjunto de enunciados que apresentam uma abertura, um desenvolvimento e um fecho, que podem ser marcados ou não. No caso do subcorpus, encontramos, principalmente nas teias relacionadas 
com encontros presenciais, mensagens de abertura, de desenvolvimento, e de fechamento. $\mathrm{O}$ autor ainda lembra que o tópico apresenta extensão variável (URBANO, 2000:94). Na pesquisa, percebi que as teias tópicas variam numa dimensão temporal de 1 a 85 dias (cf item 3.5.3, p. 86).

Marcuschi (2006:77-78) observa que, em relação à organização do tópico, existem certos marcadores de mudança de tópico e exemplifica: "isso me lembra aquela do" (e em seguida, o falante conta o caso) - é um marcador de digressão; há também o marcador que propõe uma mudança de rumo, é uma quebra - "mudando de assunto..."; o terceiro é um aviso para retornar a algo interrompido - "voltando ao assunto..."

O simples domínio da língua, não é condição única para a sustentabilidade de uma conversação. Os interlocutores devem partilhar um mínimo de conhecimentos comuns, como a aptidão lingüística, o envolvimento cultural e o domínio de situações sociais (MARCUSCHI, 2006:16). Essas caracteríscas vão determinar, entre outros, o caráter simétrico ou assimétrico da conversação.

No caso do grupo da lista Esc $\mathbf{2 k}$, percebe-se que a interação é bastante assimétrica no início, sobretudo no ano de 2000, pois a equipe gestora detinha principalmente o conhecimento tecnológico. Entretanto, com o passar do tempo, outros participantes foram adquirindo prática e conhecimento e passaram a dar contribuições relevantes, engajando-se substanciamente, fomentando discussões. Um exemplo foi comentado no item 3.5.1, p. 81 e 82 é a aluna J.R.P. que inicia várias teias e tem uma participação de destaque, tornando sua participação simétrica em relação aos integrantes da Equipe Gestora.

Outro aspecto, levantado por vários escritores, é a questão temporal. Marcuschi (1991:15) e Rodrigues (1993:18) apontam a execução numa identidade temporal (sincronicidade), condição básica da conversação.

Isso será abordado no próximo item.

4.4 - A noção de conversação eletrônica.

Pode-se perguntar se a interação eletrônica seria considerada conversação. Depois do exposto sobre conversação natural, vamos entender melhor como acontece a interação eletrônica. Comecemos com a questão temporal: 
Existem várias "modalidades" (McCLEARY, 1996; SOUZA, 2000) ou "gêneros" (MARCUSCHI \& XAVIER, 2004; MARCUSCHI, 2001: 18; MACHADO, s/d) de CMC, que podem ser divididos em dois grupos, de acordo com a dimensão temporal em que funcionam, ou seja, a interação pode ocorrer em tempo real (síncrona) ou não (assíncrona).

McCleary (1996:19) faz ainda outra divisão, tendo como parâmetro, não só o tempo em que o evento acontece, mas também o número de interlocutores envolvidos na interação. Assim, temos:

- modalidades síncronas, envolvendo dois interlocutores: TELL, TALK;

- modalidades síncronas, envolvendo vários interlocutores: IRC, MUD (Multi-User Domain), Interchange etc;

- modalidades assíncronas, envolvendo dois interlocutores: correio eletrônico (mail);

- modalidades assíncronas, envolvendo vários interlocutores: BBS (Bulletin Board Systems), Listas de discussão (listserv);

Como a pesquisa em questão está relacionada às interações polilógicas, explicarei brevemente o modo de funcionamento do IRC (Internet Relay Chat, ou mais popularmente apenas chat), em oposição às listas de discussão. ${ }^{53}$

IRC é um protocolo de comunicação bastante utilizado na internet basicamente como bate-papo (chat) e troca de arquivos, permitindo a conversa em grupo ou reservada. Para conseguir utilizar esse protocolo, é necessário, primeiro, ter um cliente de IRC, que é um programa que se comunica com um servidor de uma rede de IRC. Ao conectar-se com a rede, o usuário escolhe um apelido (nickname), que pode ser mudado a qualquer momento.

A forma mais comum de comunicação numa sessão de IRC é a conversação num canal. Apesar de o nome de um canal sugerir o assunto discutido, cada canal pode ter um tópico específico. Pela possibilidade de várias pessoas enviarem mensagens simultaneamente, ocorre o rompimento de controle de turno, resultando em turnos e tópicos paralelos.

Acompanhar uma discussão torna-se uma tarefa muito complexa, pois surgem diversos "fios de conversa" e é necessário que o usuário faça, mentalmente, as ligações coesivas entre os enunciados de um mesmo fio. Para isso, ele usa os apelidos dos remetentes colocados pelo programa e outros sinais de coesão.

Um sinal muito comum é a inserção pelo usuário do apelido do interlocutor a quem seu enunciado é dirigido. Para minimizar problemas relacionados ao discurso podem ser

\footnotetext{
${ }^{53}$ Para uma noção mais profunda das modalidades de CMC ler McCleary (1996:8-43).
} 
utilizadas também outras facilidades embutidas no IRC como: separação de conversas por canais, a rotulação dos apelidos dos remetentes, cronologia de enunciados, rotulação discriminada de mensagens particulares e separação de conversas em janelas diferentes (McCLEARY, 1996: 27-8).

Como o IRC transmite basicamente texto (em oposição a outras mídias digitais que transmitem também som e imagem), para dar mais pistas ao interlocutor sobre a entonação de uma mensagem, o locutor faz uso de outros recursos como os emoticons, ${ }^{54}$ ou abreviações como rs (risos - expressa que o locutor está rindo).

Por outro lado McCleary (1996:104) define "lista acadêmica", como uma "conversação escrita assincrônica de muitos para muitos"; Kerbrat-Orecchioni (2006:8), ao discutir a noção de interação, afirma que além da alternância entre os falantes, é necessário engajamento mútuo. Baseando-se em Grosjean e Traverso, a autora (2004:10) cita como exemplo duas situações diferentes, com o mesmo número de participantes: pessoas em uma sala de espera e amigos durante um jantar. Nesses casos a ausência ou não da "centração"55 deve ser observada.

Entendemos que a interação no grupo estudado afasta-se da conversação natural, face a face. Entretanto, ocorrem nele algumas características básicas da conversação: interação entre pelo menos dois falantes; ocorrência de pelo menos uma troca de falantes; presença de uma seqüência de ações coordenadas; envolvimento numa interação centrada.

O engenheiro de software da IBM Thomas Erickson (1999) possui vários trabalhos sobre tecnologia da comunicação, entre eles "Persistent conversation: an introduction". Nesse artigo ele afirma que a conversação muda drasticamente no meio digital, principalmente quando a interação acontece com um número maior de participantes. Entretanto, considera

\footnotetext{
${ }^{54}$ Essa palavra deriva do inglês emoti(onal) + (i)con formando (ícones de emoções). Forma de comunicação paralingǘstica, também chamado de smiley, e no Brasil de "CARacterETAS", é uma sequiência de caracteres tipográficos (letras, números, sinais de pontuação, de acentuação, etc.), tais como :-) (sorrindo, feliz), ;-) (piscando) também pode ser uma imagem (usualmente, pequena), que traduzem ou querem transmitir o estado psicológico, emotivo, de quem os emprega, por meio de ícones ilustrativos de uma expressão facial. Exemplos:

( sorrindo)

(piscando). <http://www.dicweb.com/index.htm> Acesso em 12/04/2007. Para

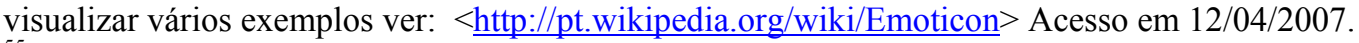

55 Optei por essa palavra, que é usada pelos analistas da conversação no Brasil, ao invés de foco, mais próximo do original "the focused or unfocused nature of the interaction" (2004:10 - grifo da autora), pois Rodrigues (1993:18) assim se manifesta: "A conversação é um evento de fala especial: corresponde a uma interação verbal

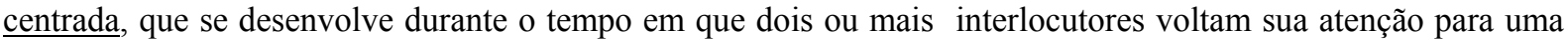
tarefa comum, que é a de trocar idéias sobre determinado assunto". [grifo meu]; e Marcuschi estabelece como característica básica da conversação" envolvimento numa 'interação centrada"'. (2006:15 - grifo meu)
} 
como conversação digital tanto a modalidade síncrona quanto assíncrona e a classifica como “conversação persistente".

Marcoccia (2004:117) justifica a expressão "conversação persistente" dizendo que a dimensão temporal existe, mas a resposta do par adjacente pode ser produzida, mesmo que, por exemplo, uma semana depois da primeira parte do discurso acontecer.

O autor (2004:117) ainda, baseando-se em Kerbrat-Orecchioni, considera a interação no grupo de discussão como um tipo particular de conversação: uma "conversação descontinuada". Nesse caso, a conversação não é a principal finalidade, mas está subordinada a outras atividades (ex. obrigações profissionais); e busca em Goffman a expressão: "estado interativo aberto" ${ }^{56}$, pois os participantes não têm necessariamente a obrigação de contribuir com turnos, permanecendo em silêncio de acordo com sua vontade. Também, a extensão do diálogo não é claramente definida, pois se organiza por meio de uma temporalidade dilatada, envolvendo pausas e retomadas. Quer dizer, a lista de discussão permite a qualquer participante juntar-se à conversação em qualquer momento, seja como mero observador, seja iniciando tópicos, ou ainda, contra-argumentando proposições anteriores (2004:117-8).

É interessante perceber que Kerbrat-Orecchioni (2006:8), em obra destinada a analisar um tipo especial de interação verbal: a conversação, afirma que para haver troca comunicativa são necessários fala alternada e engajamento mútuo. Em momento algum a autora menciona a sincronicidade como condição básica da conversação.

A reflexão que Machado (s/d:123-124) faz, classificando os chats e as listas de discussão como "gêneros conversacionais fundados no diálogo" e já apontada aqui no início do trabalho (cf item 2.9.4, p 62) é bastante pertinente.

\section{5 - Fala e escrita dentro do continuum tipológico}

Lembrando ao leitor que a conversação natural é lingua falada e conversação eletrônica é lingua escrita, farei comentários gerais na perspectiva do continuum.

Urbano (2006: 19), na esteira de Koch e Oesterreicher, afirma que podemos entender fala e escrita em dois sentidos: os meios pelo qual a língua se manifesta, sendo meio sonoro para a fala e meio gráfico para a escrita; e as maneiras de concepção de um texto. Assim um telejornal, embora seja realizado oralmente, concepcionalmente é um texto escrito. Uma carta

$56 \quad$ No original: open state of talk 
íntima, endereçada a um amigo, embora seja realizada por escrito, aproxima-se concepcionalmente um texto oral.

Em termos gerais, a língua falada apresenta uma tendência para o não planejado ou apresenta menor grau de planejamento que a escrita, pois a língua falada é planejada localmente, isto é, constitui uma atividade administrada passo a passo. Além disso há um maior grau de envolvimento entre os interlocutores. Ao iniciarem uma conversação, há um comprometimento tácito de cada um deles com o tópico conversacional. Eles se mostram de acordo com o tema que surge espontaneamente. Um segue o pensamento do outro, completando a fala, etc. É assim que funciona o processo de elaboração do texto conversacional, que é o trabalho cooperativo dos interlocutores (KOCH, 2006:39).

O leitor, enquanto receptor da mensagem escrita, não está no mesmo lugar e no mesmo momento que o escritor. Um lapso maior ou menor de tempo distanciam o ato de elaboração do texto pelo escritor e o ato de leitura pelo leitor. O escritor nem mesmo sabe quem, eventualmente, lerá seu texto, nem podemos afirmar com segurança que ele sempre esteja preocupado com esse problema, pois ele constrói sozinho o seu texto. Não dispor de dados do contexto situacional faz com que o escritor somente opere com informações passadas no e pelo texto. A língua escrita tem que compensar a ausência da situação, recuperando lingüisticamente o componente situacional.

Uma outra característica apresentada é que escritor e leitor não alternam seus papéis no decorrer da elaboração do texto escrito e por isso o autor necessita produzir algo convincente para diferentes leitores, em diferentes momentos e em diferentes lugares.

Como o escritor tem mais tempo para pensar sobre o que escreve e como escreve, pois não está numa interação face a face, ele não precisa se preocupar por prender a atenção do leitor a cada momento, como na conversação, em que há o monitoramento do interlocutor, com os sinais de quem está acompanhando o diálogo: certo, uhn uhn, ahn, ahn. Do mesmo modo que o leitor vai dispor de mais tempo para entender o escrito, podendo, em caso de dúvida, reler o texto. Além disso, como o escritor está livre das pressões do tempo, ele tem condições de se abastecer de muitas informações sobre o assunto que pretende desenvolver e pode ter uma organização mais cuidadosa dos procedimentos lingüísticos que vai adotar no seu texto (RODRIGUES, 1993:27-8).

Isso posto, pode-se dizer, então, que há um planejamento temático em maior grau no texto escrito, pois qualquer um que se proponha a escrever, sabe o tema que pretende 
desenvolver. Junto com o planejamento temático está o planejamento lingüístico, ou seja , a formulação verbal é também planejada.

Assim, fala e escrita identificam gêneros de textos concebidos como textos falados ou escritos em maior ou menor grau.

Nesse sentido, Marcuschi (2001) e Urbano (2000) entendem as práticas sociais de oralidade e letramento:

Oralidade, segundo Urbano (2000:86), pensando no conceito de língua falada, compreende não só os aspectos lingüísticos sonoros (verbais e supra-segmentais) da fala, mas também todos os demais visuais que, entornando os primeiros, os complementam, integrando o que se pode realmente chamar de língua falada. Em artigo recente, o autor aprofundou o assunto e ampliou o conceito (URBANO, 2006).

Para Marcuschi (2001:25), oralidade paralelamente é uma prática social interativa exercida por meio do canal sonoro para fins comunicativos que se apresenta sob variadas formas ou gêneros textuais, que vão desde os exemplos prototípicos orais, como as conversações naturais, até os prototípicos, relacionados à prática social da escrita. Letramento é uma prática social que abrange o uso de textos escritos desde uma apropriação mínima, como o indivíduo que, apesar de analfabeto, identifica a garrafa de Coca-Cola, ou a estação de metrô em que deve descer, até uma apropriação mais profunda, como no caso do indivíduo que escreve um artigo científico.

Cabe lembrar que, com os equipamentos informáticos e as novas tecnologias de comunicação fazendo parte de forma mais intensa da vida das pessoas nas últimas décadas, certamente o uso da linguagem tem se modificado, acompanhando essas mudanças e tornando-se cada vez mais complexo. Segundo Marcuschi (2004:14), assim como a introdução da escrita conduziu a uma cultura letrada nos ambientes em que floresceu, de igual modo, a introdução da escrita eletrônica está nos conduzindo a uma cultura eletrônica. Assim pode-se entender a "e-comunicação" (comunicação eletrônica), nas suas diversas formas: $e$ mail, chat, grupos de discussão, blog etc, como novas práticas sociais ${ }^{57}$. Com o advento dessa nova tecnologia, têm-se novas formas de letramento. Haveria, então, um letramento digital?

Hoje é praticamente impossível participar de eventos comunicativos sem o auxílio do computador, ou seja, são necessárias certas habilidades e conhecimentos técnicos mínimos

\footnotetext{
${ }^{57}$ Embora Marcuschi afirme que é cedo para falar-se em letramento digital, pois essas características merecem ser mais bem conhecidas (2004: 15 e 32), nesse livro a expressão "letramento digital" é mencionada seis vezes,
} 
para que o indivíduo "funcione" adequadamente neste novo contexto social. A Unesco, em 1978, propunha o conceito de alfabetização funcional, segundo o qual ela seria um meio de adaptação às necessidades e exigências do meio social. Há décadas, os jovens que desejassem ser escriturários necessitavam de um curso de datilografia; hoje, os chamados "cursinhos de informática" proliferam pelo país. A expressão "inclusão digital" faz parte de toda campanha eleitoral. Laboratórios de informática nas escolas públicas e privadas das grandes metrópoles já são uma realidade. A maioria da população está inserida em eventos de letramento digital: o pagamento de contas, a compra de produtos, cursos a distância, envio de currículos ${ }^{58}$ etc.

Assim, pensando em fala versus escrita e oralidade versus letramento, na perspectiva de um continuum tipológico, Marcuschi (2001: 38) representa-o com o seguinte esquema:

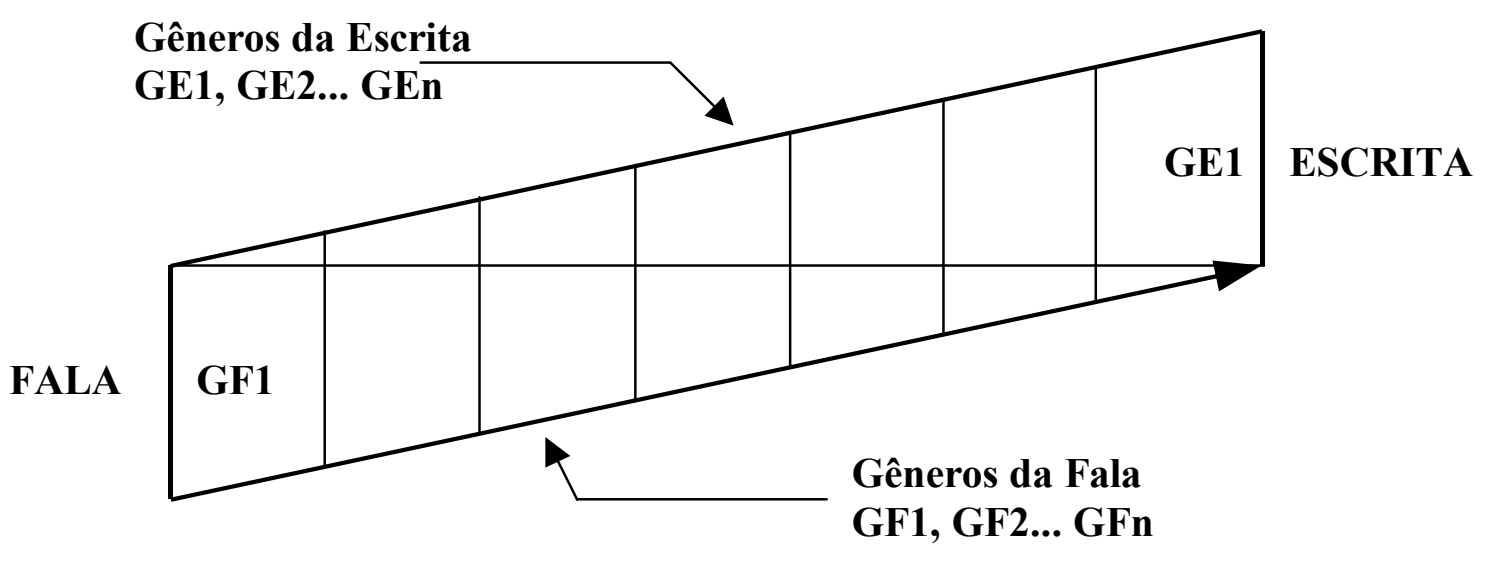

Nele evidenciam-se dois planos: o superior representa o continuum da escrita e o inferior representa o continuum da fala. GE1 representa o gênero escrito prototípico, como os textos acadêmicos e científicos; GF1 representa a conversação espontânea. Na medida em que, a partir de GE1, formos nos deslocando à esquerda para GE2, GE3,..GEn, perceberemos que os gêneros de textos vão, gradativamente, apresentando elementos de oralidade, como os

e seu sinônimo: "letramento eletrônico", duas. Cabe lembrar que no texto não há uma definição da expressão, apenas o comentário de que "já podemos dizer que temos novas situações de letramento cultural" (p.32)

${ }^{58}$ Os brasileiros são líderes em termos de acesso percentual, em diversas categorias, como Universidades $(44,7 \%$ dos internautas domiciliares acessaram sites de universidades no Brasil no primeiro trimestre de 2004, contra $44 \%$ dos internautas franceses, segundos colocados, e 43\% dos australianos, em terceiro lugar). Eles também são líderes no uso da internet para procurar empregos (29,2\% ). A Alemanha ficou em segundo lugar (26,7\%), seguida da França (25,6\%). UM em cinco brasileiros adultos já utilizou a Web. 8 jun. 2004. Disponível em: < http://informatica.terra.com.br>. Acesso em: 14 agosto 2005 
bilhetes e as cartas pessoais. Da mesma maneira, se de GF1 formos nos deslocando para a direita, em direção a GFn, encontraremos gêneros da fala com vários elementos de texto escrito, como as conferências e os discursos oficiais.

Hilgert (2000:21-22) ainda observa que em uma perspectiva conceptual, todos os gêneros de textos se distribuem ao longo de um continuum tipológico. Há uma afinidade fundadora nos gêneros de textos prototípicos (GF1 e GE1) entre o meio e a concepção correspondente, que vai diminuindo na medida em que houver um afastamento dos pólos prototípicos em direção ao pólos opostos até se constituir em uma nova afinidade, pois esses gêneros não se definem isoladamente em seu plano horizontal, mas sim na correlação vertical dos planos. Dessa forma, encontraremos no centro do gráfico, um gênero de texto que, do ponto de vista conceptual, está equilibrado entre a fala e a escrita, como "os textos noticiosos de jornais e revistas (na escrita) e dos noticiários de televisão e rádio (na fala).”

Igualmente fundamentado em Oesterreicher et al., Urbano (2006) estudou, adaptou e reformulou o esquema original dos autores no seu recente artigo "Usos da linguagem verbal" (2006:32), exemplificando com várias situações comunicativas.

\section{6 - A localização da conversação eletrônica no continuum tipológico}

A elaboração das mensagens na CMC acontecem por escrito, tanto nos chats quanto nas listas de discussão. Hilgert (2000:24) ao analisar as estratégias de construção do texto da conversação na internet afirma que os interlocutores sentem-se em uma interação falada. Essa percepção vem explicitada na formulação dos enunciados e em referências metalingüísticas, tais como "bate papo", "papo".

Na lista Esc 2k os assinantes entendem a lista como um lugar de encontro: "Vc também é galo da madrugada ? Te encontrar é sempre bom, essa hora então... " (M 917 - Teia 2). A interação, entretanto, não se dá de forma fática, como no chat. A lista é um lugar de troca e pesquisa: “Oi, pessoal!!!! Estou de volta! Não via a hora. Durante às férias dei uma olhadinha na lista telefônica, destribuida pela Telemar, e vi algumas curiocidades. Achei interessante e pensei em compartilhar com vocês." (M 857 - Teia 2); e "Pesquisei rapidinhos, nos corredores. Rômulo foi o fundador de Roma. Segundo a lenda ele foi amamentado por uma loba. Procurarei mais sobre o assunto.” (M 885 - Teia2). 
É também lugar de reflexão: "se é quem estou pensando o irmão dele é Remulo" (M 890 - Teia 2) e: "Pronto!!! O E. me deu um motivo para perder o sono. A loba tinha um nome? Parece até tarefa de gincana. Fiquei curiosíssimo com essa. Se alguém sabe, por favor, responda logo.” (M 900 -Teia 2)

Diante do exposto é possível perceber algumas características que diferem chat de lista de discussão:

a) a conversação no chat, em geral é efêmera, pois os interlocutores não se conhecem, usando normalmente apelidos. Dessa forma é comum a criação de "personagens", pois não há comprometimento de nenhuma parte;

b) as mensagens não são arquivadas, perdendo-se com a interrupção da interação;

c) a interatividade é tão grande, dependendo do número de pessoas na sala, que as mensagens em geral são curtas, não passando de uma linha;

d) usam-se abreviações o tempo todo;

e) o conteúdo informacional é bastante diluído;

f) depois de algum tempo de conversa, é comum os interlocutores tentarem se comunicar uns com os outros por outros meios, como orkut ${ }^{59}, \mathrm{msn}^{60}$, telefone...

A conversação na lista Esc 2k tem por objetivo trocar experiências; solucionar problemas; refletir conjuntamente. Muitos assinantes se conhecem, pois trabalham na mesma escola ou em escolas próximas; participam dos vários encontros presenciais que foram realizados desde o início da lista. Aqueles que não se conhecem pessoalmente, vão se conhecendo através das mensagens que vão trocando, criando um clima de intimidade. É uma comunidade delimitada. Por ser formada na sua maioria por professores, e também por ter mais tempo disponível para construir suas mensagens, os textos apresentados, de forma geral não possuem muitas palavras abreviadas. Também é comum a gravação de mensagens interessantes partilhadas pelos membros para trocarem com os alunos e a discussão de tópicos importantes da lista nas respectivas escolas.

Diante do exposto, Hilgert (2000:25) situa a conversação nos chats próxima aos textos da conversação telefônica (no plano inferior do gráfico) e das cartas pessoais e dos bilhetes

\footnotetext{
${ }^{59}$ Rede social filiada ao Google, com o objetivo de ajudar seus membros a fazer novas amizades . Foi criada em 19 de janeiro de 2004 pelo engenheiro turco Orkut Büyükkokten. $<$ http://pt.wikipedia.org/wiki/Orkut $>$ Acesso em 23/04/2007.

${ }^{60}$ MSN Messenger, ou apenas MSN, é um programa de mensagens instantâneas criado pela Microsoft Corporation. O programa permite que um usuário da internet se comunique com outro que tenha o mesmo programa em tempo real, podendo ter uma lista de amigos "virtuais" e acompanhar quando eles entram e saem da rede.
} 
(no plano superior). Sob esse aspecto, o autor ainda faz algumas observações: lembra que a comunicação por bilhete ou carta não acontece em tempo real; afirma que a carta ou bilhete podem ser entendidos como um todo de sentido independente, constituindo um texto em si.

Entretanto, para uma localização mais precisa, é necessário observar a alternância de turnos.

4.7- A conversação eletrônica e o sistema de alternância de falantes

Como vimos, um outro elemento básico da conversação natural é o turno. KerbratOrecchioni (2006:44-45) afirma que para que haja diálogo é necessário o princípio da alternância, que é resumida pela fórmula $a b a b a b$, pois só é possível um falar de cada vez. As sobreposições de fala são raras na conversação cotidiana, pois os falantes em competição devem negociar (explícita ou implicitamente) o turno.

Veremos que a produção dos assinantes no corpus estudado não se caracteriza dessa forma, pois, ao produzir uma mensagem, todos os outros assinantes “estão na vez”, ou seja, podem contribuir com mensagens respostas.

Hilgert (2000:29-30) compara a alternância dos interlocutores na conversação face a face e nos chats fazendo as seguintes observações:

a) a alternância entre os interlocutores é maior nos chats do que na conversação face a face, pois os turnos são mais curtos e são constituídos, predominantemente, por pares adjacentes;

b) o contexto de produção desestimula a considerações mais longas;

c) as conversações são simétricas, pois os interlocutores não se conhecem.

Um aspecto relevante apontado por Hilgert (2000:30-31) e comum no meio eletrônico, tanto nos chats quanto nas listas é a ausência de sobreposição de falas, pois cada interlocutor só tem acesso ao enunciado do outro depois que este aciona, no teclado do seu computador, o comando "enviar".

Sobre o intervalo entre os turnos, Hilgert (2000: 31-32) observa que ele é maior do que na conversação face a face. Isso acontece por várias razões: a escrita é mais lenta que a fala; a velocidade do meio às vezes é limitante, embora o aperfeiçoamento da tecnologia deva mudar essa relação; nas salas de bate-papo há vários interlocutores e é comum as conversas paralelas, levando os participantes a certa dispersão da atenção. 
4.8 - A alternância de falantes na lista Esc 2k:

a) exemplo 1

Uso como exemplo a teia número 33, cujo assunto é o ciclo de reportagens veiculadas no Jornal Nacional, da Rede Globo a respeito da água. Essa teia é formada por 6 mensagens, enviadas por 5 participantes. O período de duração da conversa é de 4 dias.

\section{T e i a 33}

1430 - De: A P

Data: Ter Ago 28, 2001 8:58 pm

Assunto: Agua no JN

1464 - De: N M

Data: Qua Ago 29, 2001

$8: 15 \mathrm{pm}$

Assunto: Re: [esc2k] Agua no JN
1457 - De: A P

Data: Qua Ago 29, 2001 6:18 pm

Assunto: Re: [esc2k] Agua no JN
1522 - De: eu

Data: Sex Ago 31, 2001 10:06 pm

Assunto: "Água"

Lembrando que os números de cada cabeçalho acima no diagrama é gerado automaticamente pelo sistema, temos:

Uma mensagem inicial de A.P. (M-1430) 
Oi, pessoal!

Está começando hoje no Jornal Nacional uma série de reportagens especiais sobre a ÁGUA.

Sei que vocês têm o hábito de gravar programas interessantes...

Podem, talvez, pensar em outras estratégias como debates ou mesmo imaginando se é possível fazer, na escola, outra série de reportagens (de diferentes formatos) sobre o assunto.

Bem...

Estou assistindo AGORA um dos programas...

Estão falando de tratamento de água, esgoto, captação de água, abastecimento, invasões destruindo margens de rios... enfim... assuntos"nossos", muito presentes nas escolas!!!

Espero que a dica chegue até vocês a tempo!

Beijo grande!

Drip

Essa mensagem gera uma resposta de Aur., (M 1453):

Adriana,

Não só estou trabalhando na minha escola (outra escola, pois a EM Maria da Assunção de Marco está em greve) esta série sobre á Água, como também a proposta do Ministro da Educação, Paulo Renato, de fazer um Pré- vestibular somente para negros.

Está sendo uma discussão bastante interessante.

Aur.

Belo Horizonte

A resposta gera três outras mensagens. A resposta de A.P. (M 1457),

Que legal, Aurélia!

Alguma idéia bacana para trazermos para a lista alguns dos pontos levantados pelo grupo? Chegaram a algumas conclusões?

Um abraço!

Drip

a informação de L.G. (M 1458),

Aurelia,

Para voce e todos os que estao trabalhando (ou pretendem trabalhar) a questão da água: há muitíssima coisa interessante na Internet, não sei se vocês já estiveram pesquisando.

Por agora, recomendo um site: o da Associação Brasileira de Recursos Hídricos, www.abrh.org.br

Já que estamos na água, é "navegação" para não terminar mais :-)

Abraços,

LG 
e a sugestão de N. M. (M 1464):
Aur.,
Que tal compartilhar, aqui, algumas destas opiniões "interessantes"?Poderíamos comparar as visões, estabelecer paralelos. Isso poderia até dar uma conversa interessante em um "chat" e você poderia convidar alunos ou professores de sua outra escola para participar aqui, junto com a gente. O que vocês acham da idéia?
Um abraço,
Ney Mourão
Orientador - MG

Eu (M 1522), talvez, por dispersão de atenção, faz uma proposta parecida com a de A.P. (M-1430)

\begin{abstract}
Olá galera!
Gostaria de saber se vocês, acompanharam a matéria sobre a "Água", no Jornal Nacional, estou comentando porque achei muito importante todos nós estarmos ligados a esse tipo de reportagem. Quanto mais informação maior a nossa capacidade de deselvorvermos novos trabalhos e projetos. E não se esqueça "Na Natureza nada se constrói, tudo se transforma" Vamos continuar lutando, pois cada dia mais pessoas estão se dando conta que a água é finita.

Abraços, Eu.
\end{abstract}

A dispersão de $\mathrm{Eu}$. pode ser entendida pela dinâmica de funcionamento do próprio sistema, pois entre a mensagem de A.P. (M 1430) e a de Eu. (M 1522) aparecem 92 mensagens.

Esse fenômeno é semelhante ao que Hilgert (2000: 32) descreve a respeito do chat. Nas salas de bate-papo encontram-se vários interlocutores, fazendo com que surjam interações paralelas centradas em temas que não predominam no grupo maior, aguçando outros interesses, levando a interação com outros parceiros e ao protelamento dos turnos. Do mesmo modo, nas listas de discussão, há várias mensagens para serem lidas, várias conversas ocorrendo ao mesmo tempo e o leitor nem sempre lê as mensagens em curso. No caso de Eu., percebe-se que ela não tem conhecimento das mensagens anteriores, embora esse tema já esteja em pauta. Sua proposta de desenvolvimentos de projetos já está acontecendo na escola em que Aur. trabalha. Ou seja, como já foi exposto, uma das características das listas é o fato de que os participantes podem se juntar à conversa a qualquer momento. Outra característica é que o conteúdo informacional é bem maior que nos chats. Isso ocorre porque como toda interação assíncrona, os interlocutores possuem um tempo maior para elaborar e enviar suas mensagens.

Entretanto, esse "planejamento" e essa "elaboração" ocorrem em menor grau que no texto escrito prototípico. Percebe-se que não há tanto rigor na escrita como um texto para publicação, por exemplo. É freqüente alguns tipos de erros: de digitação, dada a velocidade 
com que os usuários desses meios eletrônicos elaboram suas mensagens; de ortografia, daqueles que não conhecem bem o léxico e também não têm tempo nem paciência para consultar um dicionário, dado o grande volume de mensagens, pois o mais importante é a interação em si.

b) Exemplo 2

Há momentos de uma dialogicidade maior do que no exemplo 1. O exemplo é retirado de fragmento da teia 2: "Curiosidades".

O ponto de partida da teia é a mensagem 857, em que e uma aluna diz que leu em uma lista telefônica algumas curiosidades e gostaria de compartilhá-las com os demais assinantes. Ela divide as curiosidades de três em três e as envia quase que diariamente, durante quase dois meses. Durante esse período, essas mensagens geram várias mensagens respostas com os assinantes comentando algumas curiosidades e gerando alguns fios longos sobre os mais diversos assuntos, mensagens contando outras curiosidades, outras de incentivo, várias brincadeiras etc (cf anexo p. 145-149).

Mostro agora um fragmento do fío gerado com a mensagem 882, cujo título é “Curiosidades 4-5-6”. Nele, J.R.P. Diz: “ (...) 5- O mês de Outubro recebeu este nome porque correspondia ao oitavo mês no antigo calendário de Rômulo, e foi criado como homenagem a Marte, Deus da Guerra.” Primeiro mostro as mensagens do fio, em ordem crescente e em seguida faço um comentário do conteúdo das mensagens

(M- 883) Qual civilização pertencia o criador ou homenageado no calendario? Agora o curioso sou eu!!

M. G. M.

(M-885) Pesquisei rapidinhos, nos corredores. Rômulo foi o fundador de Roma. Segundo a lenda ele foi amamentado por uma loba. Procurarei mais sobre o assunto. Beijinhos J.R.P.

(M-886) Alguém sabe o nome do irmão dele? :o)))

Beijo!

Drip

(M- 887) Eu achei que era ele que tinha colocado fogo em Roma. Quem foi que fez isso então?

Abraços curiosos

R.M.P. 
(M-888) Ei sei, depois de Cain e Abel.

Romulo e Remo são os gemeos mais fomosos.

M.

(M-889) Hei, M.: na sua Biblia Cain e Abel eram gemeos?

E. C.

(M-890) Se é quem estou pensando o irmão dele é Remulo

M.G.M.

(M-895) Por acaso alguem sabe o nome da loba? Ela so' amamentou o Romulo ou amamentou o irmao dele tambem?

E. C.

(M- 896) Cain e Abel por acaso sao aqueles que foram amamentados por uma serpente no Jardim do Eden?

E. C.

(M-897) Não Rapaz! Não foi Romulo quem tocou fogo. Quem queimou Roma foi o Imperadar Nero.

M.

(M-899) E o Caligula, fez o quê???

E. C.

(M- 900) Pronto!!! O Eduardo me deu um motivo para perder o sono. A loba tinha um nome? Parece até tarefa de gincana. Fiquei curiosíssimo com essa. Se alguém sabe, por favor, responda logo.

Um abraço a todos,

N.M.- MG

(M- 901) A minha pergunta, Ney, e' um bom exemplo da distincao entre sentido e implicacao... Ela tem um sentido -- mas voce viu nela uma implicacao, a de que a loba realmente tinha um nome... (que pode ate' ter tido... Ou eles a chamavam simplesmente de Mater, em bom Latim.)

E. C.

(M-903) Mas por que os meninos tiveram que mamar na loba? Não tinham mãe? O que houve? Essa história de criança abandonada é assim tão antiga?

J., M., pessoal... alguém sabe mais alguma coisa?

Beijocas!

Drip

(M-904) Dizem que eles eram filhos de Zeus com uma mortal. Meio irmãos de Hércules, de Apolo, de Atena, de Afrodite. Afroditem se quizerem...

G.L.S.

(M-905) Eu acho que quando eles mamavam na loba eles não falavam latim ainda... G.L.S.

(M 907) Gente, estou me considerando assídua nessa lista, deixei de abrir um dia minha caixa e hoje fiquei "baratinada" com tanta badalação. Juliana vc conseguiu mexer com todos, percebi que aproveitou bem as férias. Estou impressionada !!! Beijos

L.M.A -Crato-CE 
(M 911) Ju. Curiosa (graças a Deus) aproveitou bem as férias hein ?Valeu tb a preocupação por aquele assunto das carteiras. Se eu pudesse fazer pedidos a um gênio com certeza pediria para te clonar (brincadeirinha).

Beijos

L.M.A - Crato-CE

(M 916) Gilberto que loucura é essa ? Vcs entraram no túnel do tempo ?

L.M.A - Crato-CE

(M 917) Gilberto Vc também é galo da madrugada ? Te encontrar é sempre bom,essa hora então...A título de sugestão acho que poderíamos promover uns chat para depois da $22 \mathrm{~h}$ em dias alternados, até porque como já dizia Simone depois das $10 \mathrm{~h}$ não tem mais censura ( brincadeira)

L.M.A - Crato-CE

(M 922) Mas não foi a loba que ensinou latim para os dois ? Hahaha.

Não me lembro bem dessa lenda, que fala sobre a criação de Roma, mas outro dia li um artigo que dizia que os mitos/lendas de criação de cidades e povos quase sempre começam com uma morte ou sacrificio humano.

O.N.

(M 931)Caligula. Quem e esse

J.R.P.

(M 932)Drip,

Prometo que vou pesquisar sobre essa loba!

Também estou curiosa.

J.R.P.

(M 933) Mare, bobinha

Eu também te clonaria, para ficarmos o dia inteiro batendo perna e tirando foto. :.))) Beijinhos

J.R.P.

Crato-Ce

(M 934) Eu tenho alguma coisa que fala sobre isto, só que é do $1^{\circ}$ ano e ainda não achei.

Mas Prometo que quando encontrar enviarei para a lista (...)

M.G.M.

(M 942) Oi, M.! Este túnel do tempo começou com uma viagem da J.! Ju embarcou e nós fomos atrás! Acho que acabamos indo parar direto em Roma...

De lá, surgiram Rômulo, Remo, a loba, Nero e Calígula... e a história segue!

Caim e Abel entraram de carona...

Acho que estamos tentando descobrir mais sobre esse pessoal!

Seria bom se todas as novas descobertas fossem compartilhadas na lista, não?

Tem algum grupo aí que já tem mais algum dado a respeito desse assunto?

Ou, a pedidos, mudaremos de CURIOSIDADES, com base nos mails da Juliana?

O que acham?

Beijocas!

Drip

Ao lermos as mensagens sequencialmente, percebemos que há um entrecruzamento de informações. Mensagens são questionadas, respondidas, comentadas, umas se ligando mais fortemente a umas do que outras, formando um 
emaranhado todo relacionado à história de Roma. Comento algumas das mensagens: a mensagem 882 gera o questionamento de M.G.M., na M-883, que é respondida na M885, ou seja, Rômulo foi o fundador de Roma. Essa mensagem gera questionamentos: qual o nome de seu irmão (M-886); se não foi ele, quem colocou fogo em Roma (M887); ele e seu irmão seriam gêmeos famosos (M-888); o nome da loba, e se ela (a loba) teria amamentado os dois irmãos; porque os meninos tiveram que mamar na loba. Essas mensagens geram outras. A M-886 gera a resposta na M-890, seu irmão é "Remulo" (esse aluno não leu a M-888 em que é mencionado o nome correto de Remo, irmão de Rômulo). A M-887 gera a resposta de quem colocou fogo em Roma foi Nero (M-897) e o questionamento em M-899, se Nero pos fogo em Roma, Calígula fez o quê? A M-888 gera a ironia na M-889, se na Bíblia daquele assinante, Cain e Abel são gêmeos etc.

A M-907 retoma todo o fio, falando da conversação em si. Em seguida, essa mesma emissora envia a M-911, ligada as mensagens que J.R.P. envia, de uma maneira geral e envia também as mensagens M-916 e M-917, dirigidas a G.L.S. A mensagem M-916 será respondida por A. P. na M-942, que retoma as mensagens anteriores, parafraseando e sintetizando esse fio.

Nesse fragmento, participaram dez emissores com um total de 26 mensagens. $\mathrm{O}$ conteúdo informacional, embora não seja tão diluído como nos chats, apresenta-se bastante fragmentado, com um participante completando informações ou respondendo questões levantadas anteriormente, montando um texto sobre um período da história de Roma de forma coletiva. Tudo isso acontece em menos de 24 horas. Das 17:25 do dia 8 de agosto até às 18:24 do dia 9 de agosto. Nesse fragmento a alternância de falantes é bem maior que no exemplo 1.

Diante do exposto e comparando com a localização que Hilgert (2000:25) faz dos chats, temos:

a) no plano inferior do gráfico (item 4.3, p. 103) os chats se aproximam dos textos da conversação telefônica e no plano superior à esquerda dos bilhetes.

b) a lista de discussão, pelas características já mostradas nesse capítulo, encontra-se à direita dos chats, pois está mais próximo dos textos escritos que esses, embora ainda longe do texto escrito prototípico. 
Fico completamente perdido com mensagens que nao identificam a que e' que elas estao fazendo referencia... Qual foi a resposta da Dri P.? Com o que ela concorda e qual e' a jornada que ela apoia?

Luzes!

E. C. (M-852, Teia 32)

Oi, E....

Achei que eu é que havia perdido algum capítulo da novela, mas vejo que o capítulo é que acabou não indo ao ar ou, então, nós dois estávamos no mesmo " apagão". Também fiquei curioso em saber o que a Dri anda apoiando.

Um abraço a todos - apoiadores e realizadores!

$\mathrm{N} \mathrm{M}$

Orientador - MG (M-854, Teia 32)

\section{RECONSTRUÇÃO DA CONVERSAÇÃO POR MEIO DE ELEMENTOS DE COESÃO SEMÂNTICA ENCONTRADO NAS TEIAS}

Este capítulo pretende mostrar que é possível organizar um fluxo de mensagens de um grupo de discussão em conversações compreensíveis. Algumas ferramentas disponíveis provêm da própria engenharia desse gênero e outras são discursivas. Alguns exemplos desses elementos de coesão que auxiliam o usuário a entender a conversação eletrônica são: o cabeçalho - co-texto anexo a cada mensagem com informações sobre o assunto, procedência, destinação, data e hora de envio da mensagens - e marcas de inter-relacionamento colocadas nas correspondências, como paráfrase, paralelismo substituição, repetição etc.

Entretanto, antes de entrar propriamente no conceito de coesão, vou examinar o conceito de texto, para situar melhor o leitor.

Entendo texto com base na Lingüística Textual de linha sociocognitiva-interacional, ou seja, texto como um lugar de interação entre atores sociais e de construção interacional de sentidos (KOCK, 2004:xii). É o texto em funções, texto em uso (KOCH, BENTES, CAVALCANTE, 2007:12).

Essa teoria tem uma concepção dialógica de língua. Nesse sentido, a produção de texto passa a ser entendida como uma atividade interativa altamente complexa de produção de sentidos. Essa atividade se realiza por meio da mobilização de saberes enciclopédicos e pela reconstrução dos sujeitos no momento de interação verbal, tendo, como base, não só os 
elementos lingüísticos presentes na superfície textual, mas também sua forma de organização (KOCK, 2004:32-33).

A autora (2004:35), na esteira de Beaugrande \& Dressler, apresenta sete princípios de construção textual do sentido. Cinco deles: situcionalidade, informatividade, intertextualidade, intencionalidade e aceitabilidade são centrados no usuário; dois deles: coesão e coerência são centrados no texto (KOCH, BENTES, CAVALCANTE, 2007:12). Para o estudo em questão, ficarei com os critérios centrados no texto, na visão de Beaugrande \& Dressler.

\section{1 - Sobre coesão}

Antunes (2005:46-47), ao tentar estabelecer critérios para explicar o que é coesão, afirma que ninguém fala de forma desarticulada; todo texto (falado ou escrito) se realiza de forma encadeada, umas partes sempre estão ligadas às outras, não deixando nada solto. Aquilo que é dito em determinado lugar no texto se liga em algum outro ponto, tanto anteriormente, quanto subseqüentemente. Cada segmento do texto, seja nas suas unidades menores, como as palavras, seja nas unidades maiores, como os parágrafos, estão presos a muitos outros. "É por isso que se vai fazendo um fio, ou melhor, vão-se fazendo muitos fios, ligados entre si, atados, com os quais o texto vai sendo tecido, numa unidade possível de ser interpretada." Assim, um "texto com seqüência, em que se reconhece um tipo qualquer de continuidade, de articulação, é que constitui a normalidade dos textos com que interagimos." E mais à frente afirma: "essa propriedade pela qual se cria e se sinaliza toda espécie de ligação, de laço, que dá ao texto unidade de sentido ou unidade temática."

Antunes (2005:48) ainda afirma que os autores Halliday \& Hasan , ao definirem coesão, apelam para a metáfora do "laço" com a intenção de mostrar que em um texto não pode haver "pontas soltas", os vários segmentos precisam estar ligados a pelo menos um outro segmento. Koch (2004:35 e 2005:15) também fala em tecido (tessitura) formado pelos elementos lingüísticos presentes na superfície textual interligados, formando uma unidade de nível superior à da frase.

Ao tentar estabelecer critérios de coesão, Fávero (2006:17) faz uma proposta de "classificação em termos das funções que exercem esses mecanismos na construção do texto e 
não de classes de palavras, de léxico etc." Assim, a autora propõe três tipos de coesão: referencial, recorrencial e seqüencial.

Koch (2005: 27) também toma por base a função dos mecanismos coesivos na construção da textualidade e faz uma divisão da coesão em duas grandes modalidades: "a coesão remissiva ou referencial (referenciação, remissão) e a coesão seqüencial (seqüenciação)."

Observei que o assinantes da lista Esc 2 K compreendem as mensagens enviadas e participam das conversas em curso por meio de critérios semânticos e por isso optei por Antunes (2005: 50) que também faz uma divisão da coesão em três tipos por meio de critérios semânticos, expressos por relações de reiteração, associação e conexão.

Reproduzo abaixo o quadro elaborado por Antunes (2005:51):

\begin{tabular}{|c|c|c|c|c|}
\hline & $\begin{array}{l}\text { Relações Textuais } \\
\text { (Campo 1) }\end{array}$ & $\begin{array}{l}\text { Procedimentos } \\
\text { (Campo 2) }\end{array}$ & $\begin{array}{l}\text { Recursos } \\
\text { (Campo 3) }\end{array}$ & \\
\hline & 1.REITERAÇÃO & 1.1. Repetição & 1.1.1. Paráfrase & \\
\hline & & & 1.1.2. Paralelismo & \\
\hline & & & 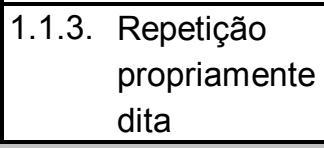 & $\begin{array}{l}{ }^{\circ} \text { de unidades do léxico } \\
\text { o de unidades da } \\
\text { gramática }\end{array}$ \\
\hline 은 & & 1.2. Substituição & $\begin{aligned} \text { 1.2.1. } & \text { Sustituição } \\
& \text { gramatical }\end{aligned}$ & $\begin{array}{l}\text { Retomada por: } \\
\text { o promomes ou } \\
\text { o por advérbios }\end{array}$ \\
\hline $\begin{array}{l}\text { E } \\
\text { w } \\
0 \\
0 \\
0 \\
0\end{array}$ & & & \begin{tabular}{|ll} 
1.2.2. & $\begin{array}{l}\text { Sustituição } \\
\text { lexical }\end{array}$
\end{tabular} & \begin{tabular}{|l|} 
Retomada por: \\
${ }^{\circ}$ sinônimos \\
${ }^{\circ}$ hiperônimos \\
${ }^{\circ}$ caracterizadores \\
sitacionais \\
\end{tabular} \\
\hline 岂 & & & 1.2.3. Elipse & $\begin{array}{l}\text { Retomada por } \\
\text { elipse }\end{array}$ \\
\hline & 2. ASSOCIAÇÃO & 2.1. Seleção lexical & $\begin{array}{l}\text { Seleção de palavras } \\
\text { semanticamente } \\
\text { Próximas }\end{array}$ & $\begin{array}{l}\text { o por antônimos } \\
\text { o por diferentes } \\
\text { modos de relações } \\
\text { de parte/todo }\end{array}$ \\
\hline & 3. CONEXÃO & $\begin{array}{l}\text { 3.1. Estabelecimento de } \\
\text { relações sintático- } \\
\text { semânticas entre } \\
\text { termos, orações, pe- } \\
\text { ríodos, parágrafos e } \\
\text { blocos suprapará- } \\
\text { grafos }\end{array}$ & $\begin{array}{l}\text { Uso de diferentes } \\
\text { conectores }\end{array}$ & $\begin{array}{l}{ }^{\circ} \text { preposições } \\
{ }^{\circ} \text { conjunções } \\
{ }^{\circ} \text { advérbios } \\
{ }^{\circ} \text { e respectivas } \\
\text { locuções }\end{array}$ \\
\hline
\end{tabular}


As relações textuais (campo 1 - quadro) responsáveis pela coesão acontecem por meio de procedimentos (campo 2 - quadro), que se realizam por meio de diferentes recursos (campo 3 - quadro).

1- A REITERAÇÃO está relacionada à continuidade do fluxo do texto," como se um fio o perpassasse do início ao fim" É o movimento constante de volta aos segmentos anteriores ou de antecipação de segmentos seguintes. $O$ texto se desenvolve em um movimento de dependência daquilo que foi dito antes, ligando-se umas palavras a outras. A autora ainda observa (2005:53) que "cada vez que substituímos uma expressão por um pronome ou por um sinônimo, por exemplo, ou que repetimos uma palavra, estamos reiterando, estamos promovendo a continuidade do texto, sua seqüência, sua coesão."

A reiteração, relação pela qual os elementos do texto são retomados, se realiza por meio dos seguintes procedimentos: repetição e substituição.

a) São recursos de repetição: a paráfrase, o paralelismo e a repetição propriamente dita:

- A paráfrase é uma espécie de tradução do enunciado, mas dito de outra forma, a fím de explicá-lo melhor, deixando o conteúdo mais transparente;

- O paralelismo ou simetria de construção acontece quando os elementos coordenados entre si apresentam a mesma estrutura gramatical;

- A repetição propriamente dita corresponde a fazer reaparecer no texto alguma palavra ou seqüência de palavras que já ocorreram anteriormente.

b) Pode-se recorrer a alguns recursos para marcar a inter-relação de sentido entre as partes do texto sem ter que repetir as mesmas palavras. Pode-se substituir uma palavra por outra equivalente. Esse recurso divide-se em substituição gramatical (retomada por pronomes ou advérbios), substituição lexical (retomada por sinônimos, hiperônimos ou caracterizadores situacionais) e retomada por elipse:

- A substituição gramatical acontece quando troca-se uma palavra por uma expressão referencial, como os pronomes ou advérbios;

- A substituição lexical implica o uso de uma palavra no lugar de outra que lhe seja semanticamente equivalente. É o caso dos sinônimos, hiperônimos e caracterizadores situacionais (uso de expressões que funcionam como uma descrição desse referente);

- A retomada por elipse, que a autora (2005:117), na esteira de Halliday \& Hasan denomina de substituição por zero, é o resultado da omissão ou ocultamento de um termo que 
pode ser facilmente identificado pelo contexto (entendendo a zeugma como uma forma de elipse)

2 - A ASSOCIAÇÃO, relação que se cria no texto graças à ligação de sentido entre palavras de um mesmo campo semântico, está relacionada à unidade temática, pois todo texto é desenvolvido sobre tópicos (cf 4.3, p. 96). É a chamada coesão lexical do texto (ANTUNES, 2005:125), pois há uma convergência das palavras quanto ao sentido que expressam, criando, assim, uma rede de relações. Por isso nenhuma palavra fica inteiramente solta, sem estar vinculada a nenhuma outra, esteja ela próxima ou distante.

As unidades lexicais de um texto podem estar associadas por causa de:

a) relações de antonímia, como natural, artificial; ônus, bônus; clássico, contemporâneo; síncrono, assíncrono etc;

b) relações de co-hiponímia (dois hipônimos, como em cão e gato, ou seja, dois membros diferentes da mesma classe de seres). Exemplos: hardweare, chip, mouse; e-mail, chat, lista de discussão; Urano, Netuno, Plutão; casado, solteiro, viúvo etc. Deve-se lembrar, porém, que os nomes co-hipônicos muitas vezes funcionam em textos como antônimos;

c) relações de partonímia (qualquer relação de parte pelo todo): rio, margem, nascente, foz, curso; concreto, cimento, cal, parede, azulejo, piso; computador, web, internet, spam, blog etc.

A autora (2005:133-134) ainda observa que essas relações se desdobram, tornando-se bastante complexas, com limites pouco claros. Dessa maneira, a relação de parte com o todo é tão ampla que dificilmente encontraremos um texto em que as palavras estejam totalmente desvinculadas umas das outras.

Os textos, em geral, são formados pelos 'nós' que essas relações possibilitam. Além disso, o conhecimento de mundo (esquemas de organização da realidade) "constitui uma base bastante significativa para muitas das associações que se fazem relevantes em um texto" (p. 137).

3 - A CONEXÃO é um recurso coesivo que promove a seqüencialização de diferentes porções do texto por meio de conectores. Ela se diferencia dos demais recursos coesivos por envolver ligações em pontos bem determinados do texto, como entre orações e períodos.

A conexão pode ser marcada por meio de conjunções, preposições, locuções conjuntivas e preposicionais, bem como por meio de alguns advérbios e locuções adverbiais. Além disso, a autora alarga o âmbito da conexão e inclui não só os nexos que se estabelecem 
entre termos de uma oração ou entre orações, mas também aqueles que ocorrem entre períodos, entre parágrafos e até entre blocos maiores do texto, chamados genericamente de 'segmentos' (p. 141) ou 'blocos supraparagráficos' (p. 51)

Encerro esse tópico com palavras da autora (2005:139):

A coesão ultrapassa a simples marca superficial do texto ou a simples justaposição de palavras ou frases. Os diversos tipos de recursos coesivos, pelos quais se espera que haja a necessária continuidade e articulação das subpartes, têm de estar em interação e vinculados a sentidos globais e a intenções comunicativas, o que, de fato, dará ao 'texto' o estatuto de sua unidade.

\section{2 - Sobre coerência}

Antunes (2005: 174) inicia sua discussão sobre coerência, com o texto abaixo:

Subi a porta e fechei a escada.

Tirei minhas orações e recitei meus sapatos.

Desliguei a cama e deitei-me na luz

Tudo porque

Ele me deu um beijo de boa noite...

(autor anônimo)

Em seguida, reflete que a aparente incoerência do texto é proposital, pois o sentido que o leitor apreende está na forma como tudo foi dito, pois "os amantes perdem o sentido unívoco das coisas; vêem numa outra ordem; subvertem a ordem natural das coisas" (ANTUNES, 2005: 175).

Ela ainda lembra que a coerência desse texto ocorre porque vemos nele uma unidade de sentido, de intenção, embora o leitor, para entendê-lo, tenha que ultrapassar a mera recuperação dos sentidos isolados de cada palavra.

Assim, coerência é uma propriedade relacionada com "as possibilidades de o texto funcionar como uma peça comunicativa, como um meio de interação verbal" (ANTUNES, 2005:176).

Dependendo do que queremos dizer e de como queremos interagir com o outro é que faremos uso da linguagem. Por isso, além de a coerência depender de fatores lingüísticos, ela também depende de fatores contextuais, extralingüísticos e pragmáticos para se efetivar. Assim, a coerência depende de cada situação, tanto dos sujeitos envolvidos e suas intenções comunicativas, quanto de tudo o mais em relação à língua ou aos fatos sociais. 
Nesse sentido, a autora observa que as relações entre coesão e coerência são bastante estreitas e interdependentes, ou seja, "a coesão é uma decorrência da própria continuidade exigida pelo texto, a qual, por sua vez, é exigência da unidade que dá coerência ao texto." Por isso é tão artificial separar coesão de coerência quanto forma de conteúdo, por exemplo. Ela ainda completa (2005:177-179):

\begin{abstract}
A coesão está em função da coerência, no sentido de que as palavras, os períodos, os parágrafos, tudo, qualquer segmento se interliga no texto para que ele faça sentido, para que ele se torne interpretável. (...)

Não é que as duas propriedades se confundam, no sentido de que não se possa defini-las. O que não é possível, ou pelo menos, não parece muito produtivo, é que queiramos demarcar com precisão onde acaba uma e começa a outra.
\end{abstract}

A autora (2005:182-186), na esteira de Charolles, propõe algumas regras de coerência:

a) meta-regra da repetição: é a mesma regra coesiva que a autora denominou de reiteração e que Charolles chama de repetição, embora seja aqui, tomado em sentido amplo, englobando a repetição propriamente dita, a paráfrase, o paralelismo e os recursos da substituição. Nesse sentido comprova o aspecto de intersecção entre coesão e coerência, pois coincide com toda a primeira parte da coesão;

b) meta-regra da progressão: completa a primeira meta-regra, pois um texto deixa de ser coerente quando repete indefinidamente o mesmo conteúdo. Em outras palavras, para que um texto seja coerente, deve existir uma progressão semântica, pois o ato de se comunicar exige que os interlocutores acrescentem informações para que o diálogo flua;

c) meta-regra da não-contradição: no desenvolvimento do texto não se deve introduzir nenhum elemento semântico que contradiga um conteúdo posto ou pressuposto anteriormente;

d) meta-regra da relação: essa regra pragmática estabelece que os indivíduos, os fatos, as ações as idéias, os acontecimentos ativados em um texto sejam percebidos como congruentes, ou seja, guardem algum tipo de ligação entre si.

Diante do exposto, a autora reafirma que as regras de coerência textual estão estreitamente ligadas com as determinações da coesão. Acreditando que qualquer atividade verbal é coerente, os interlocutores usam várias estratégias para construir uma unidade de sentido ao discurso do outro.

Como meu estudo fundamenta-se no conceito de coesão, centrar-me-ei nesse conceito. Além disso, existem alguns elementos coesivos específicos ao corpus, como "nó" (união de teias/fios); alguns elementos que são estabelecidos pelo gerenciamento do programa, como o 
cabeçalho (de preenchimento obrigatório pelos assinantes), onde constam os campos: 'assunto', 'procedência' e 'destinação'. A data e hora de envio das mensagens também é feita automaticamente.

\section{3 - Coesão no fluxo de mensagens da lista Esc 2 k}

O fluxo de correspondências de um grupo de discussão é aparentemente caótico. Como descobrir onde começa e termina uma conversa? O fluxo cronológico de correspondências é considerado um não texto natural, pois cada mensagem é um pedaço de um texto maior, que se completará várias mensagens depois, sem formar uma seqüência linear. Por isso o leitor se guia primeiramente pelo rótulo de assunto, antes mesmo de abrir sua mensagem. A figura 5, p. 47 mostra a janela de trabalho do Outlook Express; nela o leitor pode perceber como se dá o funcionamento da chegada de mensagens. Geralmente ela é encaminhada pelo horário de chegada (ficando a mais recente em primeiro lugar), entretanto, se o assinante clicar em 'de' ou 'assunto' a ordenação muda. O usuário também pode inverter as correspondências por data, deixando as mais antigas em primeiro lugar.

A figura 5 também mostra que a pasta Esc 2k é a que está aberta, estando escurecida na relação de pastas locais e também em uma linha de destaque, logo abaixo. McCleary (1996:175) observa que esse recurso não estava disponível ao usuário comum da época.

No fluxo de mensagens da lista, percebe-se que as mensagens pertencem a 'conversas' diferentes. Na coluna assunto, temos (ainda figura 5, p. 47):

'Arquivo-assinatura', 'Boletim - Sua escola a 2000 por hora' e 'Boletim', 'O sentido da escola', 'Feliz dia dos professores!'. As mensagens 'Arquivo-assinatura' está aberta na janela abaixo desse fluxo e pode-se perceber que ela não está ligada a nenhum fio/teia, pois é uma mensagem enviada periodicamente à lista para lembrar ao usuário de alguns procedimentos básicos; as mensagens com assunto 'Boletim' são convites enviados pela Equipe Técnica do IAS, convidando a comunidade para encontros virtuais, cursos à distância ou para a leitura de textos, reportagens ou entrevistas interessantes no site do 'Programa Sua escola a 2000 por hora'. Portanto, dessas mensagens todas, temos apenas dois assuntos distintos: 'O sentido da escola' e 'Feliz dia dos professores!'. Entretanto, é importante lembrar que essas mensagens são de 2006. No período estudado havia o envio de até 50 mensagens em um único dia. 
Como se pode perceber, a coesão é elemento imprescindível para o entendimento da lista. Como já mostrado no item 4.8 (p. 107) a alternância de falantes é bastante complexa na lista, pois, para um pergunta, pode vir um número incontável de respostas; não se fala um por vez, na verdade todos 'estão na vez'. Assim, os pares adjacentes não aparecem mais adjacentes, e o leitor precisa ir buscando no fluxo a continuidade, a resposta de uma pergunta.

Um outro elemento organizador da conversação e já apontado no item 4.3 (p. 96) é o tópico discursivo, que é muitas vezes usado como sinônimo de fio, termo originado nas listas de discussão, e entendido como um conjunto de correspondências inter-relacionadas que tratam de um mesmo assunto (McCLEARY, 1996: 140).

A relação entre fio, rótulo de assunto e tópico é bastante complexa. Nos programas de gerenciamento de correio eletrônico há a opção de ordenar as mensagens por rótulo de assunto. Entretanto isso só funciona nos casos de fios simples e ordenados, coisa rara na lista. Se o leitor se guiar apenas por esse elemento, poderá ter problemas, pois o rótulo é bastante traiçoeiro (cf 3.2, p. 65). O tópico pode sofrer um desvio, embora o usuário mantenha o mesmo rótulo na sua mensagem - é mais fácil e rápido clicar no ícone encaminhar ou responder do que digitar um novo assunto; o tópico pode continuar igual, mas o usuário, por não saber utilizar as ferramentas automáticas adequadamente, ou por querer dar um caráter mais pessoal à sua correspondência, digita um novo assunto no rótulo - o gerenciamento automático do software entenderá que se trata de um novo fio; como cada mensagem pode gerar inúmeras respostas, nesse caso nenhuma ordenação linear de correspondências será capaz de captar essa ramificação do tópico (McCLEARY, 1996: 141-142).

\section{4 - Teia tópica}

McCleary entende teia tópica como um conjunto autônomo de fios discursivos dentro da atividade da lista. E entende coesão de forma ampla, sendo um elemento básico de interrelacionamento desses elementos. Para que o leitor entenda as mensagens, ele precisa de conhecimentos de mundo partilhado pelos membros da lista (conhecimento em informática, informações sobre as escolas participantes etc.) ou informações específicas em outras correspondências do mesmo fluxo. Isso nos leva a perceber que a correspondência da lista é um texto incompleto, um turno isolado, um não texto, pois os textos, em geral, normalmente se encontram prontos para serem lidos. O fluxo do grupo de discussão não (1996:171-172), 
pois é o assinante que constrói cada uma das conversas à medida que vai lendo cada uma das mensagens e inserindo mentalmente cada mensagem em sua respectiva teia.

Em seguida, mostro como que a teia 32 foi formada com base nesses elementos coesivos. Ela foi escolhida porque um tópico levantado nessa teia é justamente a falta de entendimento da conversa que ela estava restrita a dois participantes. Pela sua relevância coloquei em destaque as mensagens 852 e 854 como epígrafe desse capítulo:

\section{Exemplo 1}

Essa teia, cujo título é "Comemoração", consta de 6 mensagens, enviadas por 5 participantes, no dia 7 de agosto de 2001:

a) Primeiramente coloco a síntese da conversa: a conversação se inicia com um participante do fórum agradecendo a resposta que outro lhe enviou e o apoio que lhe deu em sua nova jornada. Um outro participante manifesta seu desagrado com e-mails que só podem ser entendidos por alguns, pois não faz referência à conversa anteriormente travada. Pergunta o que está sendo conversado entre os dois primeiros. Mais um participante manifesta sua curiosidade sobre o assunto. Desta forma, os dois primeiros percebem que as outras pessoas que participam do fórum querem estar a par dos fatos, não cabendo no fórum mensagens particulares. Sendo assim, esclarecem que a resposta e o apoio se referiam à nova jornada como monitor do laboratório de informática da escola em que um deles trabalha. A partir daí pode receber o apoio de outros participantes e compartilhar experiências.

b) Em seguida, mostro a teia diagramada, com todos os cabeçalhos: 


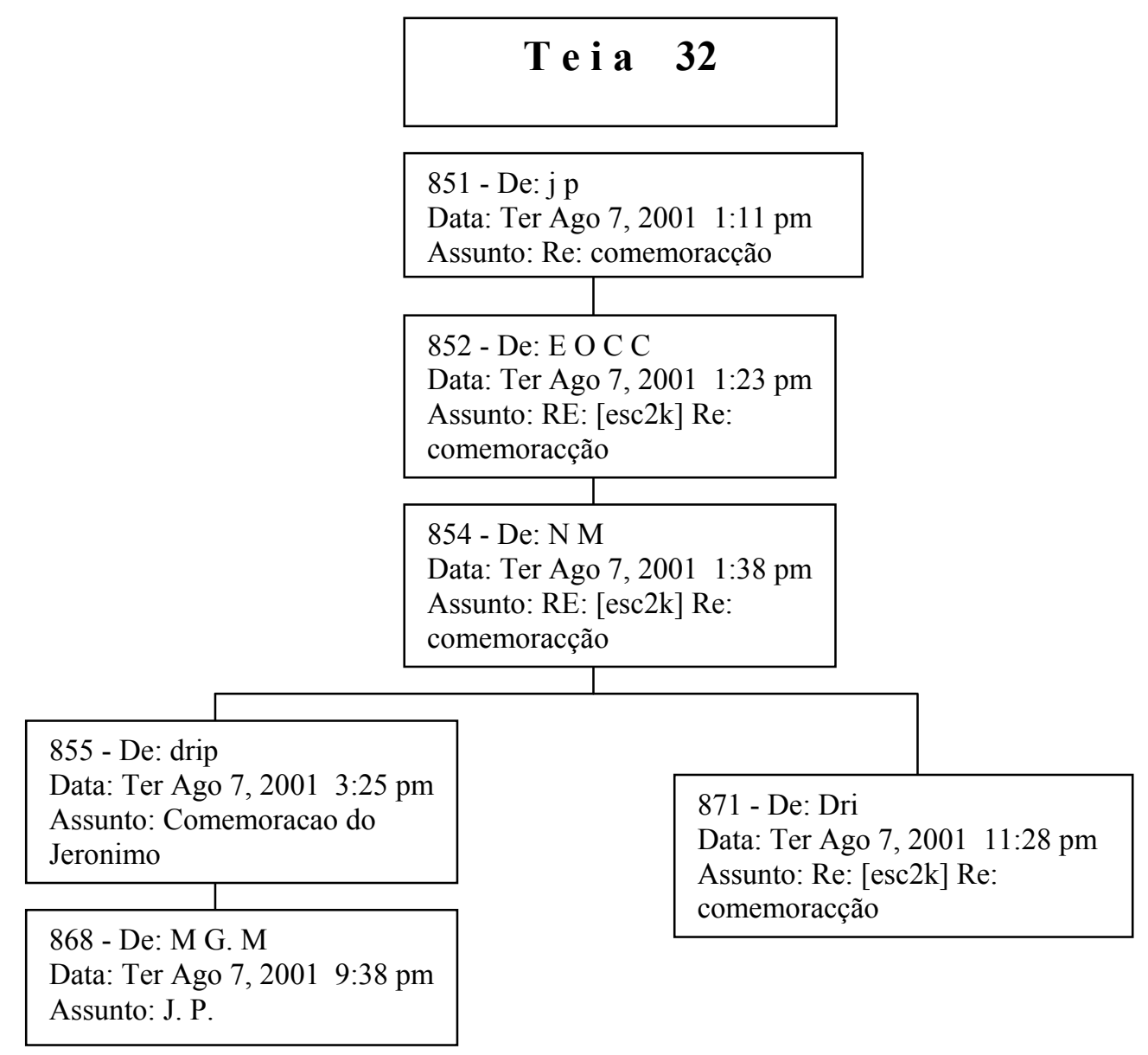

Como podemos perceber, essa teia é bastante homogênea em relação ao assunto do cabeçalho. A única mudança ocorre na M-868, onde o nome do assinante que inicia a teia J. P. passa a ser o assunto da mensagem. Também é importante lembrar que as mensagens que fazem parte da teia não são todas as mensagens que foram enviadas ao grupo nesse fluxo, pois as mensagens 853,856 até 867,869 e 870 (15 mensagens) fazem parte do fluxo mas pertencem a outras teias em curso.

c) o conteúdo das mensagens

Em seguida, reproduzo integralmente as mensagens, inclusive com o cabeçalho e as citações anteriores, em ordem cronológica: 
Mensagem 851

CABEÇALHO: De: "j. p."

Data: Ter Ago 7, 2001 1:11 pm

Assunto: Re: comemoracção

MENSAGEM: DRI

Só hoje pude ver sua resposta,pois você já sabe né? Só uso computador na escola pois não possuo um e estava de férias, mas de quaLquer maneira fico feliz pois concorda e me apoia nessa mais nova jornada.

\section{ATÉ LOGO!!!!!!!!!!!!!!!!!!!!!!}

Respostas Nome/E-mail Data

$852=$ ?iso-8859-1?Q?RE:_=5Besc2k=5D_Re:_comemorac $=$ E7=E E O O C Chaves

Ter, 7 de Ago de 2001 1:21pm

854 RE: [esc2k] Re: comemoracção N M

Ter, 7 de Ago de 2001 1:37pm

Mensagem 852

CABEÇALHO: De: "E O C C"

Data: Ter Ago 7, 2001 1:23 pm

Assunto: RE: [esc2k] Re: comemoracção chaves@...

MENSAGEM: Fico completamente perdido com mensagens que nao identificam a que e' que elas estao fazendo referencia... Qual foi a resposta da Dri

Portella? Com o que ela concorda e qual e' a jornada que ela apoia?

Luzes!

E C

-----Original Message-----

From: jeronimo prudencio [mailto:jeronimoprud@...]

Sent: Tuesday, August 07, 2001 1:11 PM

To: driportella@...

Cc: esc2k@yahoogroups.com

Subject: [esc2k] Re: comemoracção

DRI

Só hoje pude ver sua resposta, pois você já sabe né? Só uso computador

Respostas Nome/E-mail Data

854 RE: [esc2k] Re: comemoracção Ney Mourão

Ter, 7 de Ago de 2001 1:37pm 
Mensagem 854

CABEÇALHO: De: N M

Data: Ter Ago 7, 2001 1:38 pm

Assunto: RE: [esc2k] Re: comemoracção neymourao@...

MENSAGEM: Oi, E...

Achei que eu é que havia perdido algum capítulo da novela, mas vejo que o capítulo é que acabou não indo ao ar - ou, então, nós dois estávamos no mesmo " apagão". Também fiquei curioso em saber o que a Dri anda apoiando.

Um abraço a todos - apoiadores e realizadores!

N M

Orientador - MG

At 13:23 07/08/01 -0300, you wrote:

$>$ Fico completamente perdido com mensagens que nao identificam a que e' $>\mathrm{E} \mathrm{C}$

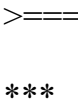

Mensagem 855

CABEÇALHO: De: dri p.

Data: Ter Ago 7, 2001 3:25 pm

Assunto: Comemoracao do J.

MENSAGEM: Olá, J.!

Fico feliz pelo fato do retorno às aulas ter possibilitado que você voltasse a utilizar o computador da escola.

Fico também alegre porque você compartilha conosco a mensagem que fala do seu novo desafio.

Entretanto, precisamos lembrar que desta lista fazem parte muitas pessoas e que nem todas elas nos conhecem...

Então eu vou voltar a lembrar que é sempre bom a gente se identificar.

Você pode colocar, logo no fim da sua mensagem:

"J. P.

CE Dom Otaviano de Albuquerque

Campos - RJ"

Também o assunto da sua mensagem tinha sido conversado comigo e acho que o pessoal não sabia muito sobre o que você estava falando.

$\mathrm{O}$ desafio ao qual você se refere foi o de aceitar a função de monitor, ficando responsável pelo laboratório da escola.

Nós dois sabemos o quanto isso é importante para você e para a escola. Mas o pessoal da lista "estava por fora", assim como a gente diz: eles "pegaram o bonde andando".

Acho que seria até bem legal se você contasse um pouco mais da sua história, de como iniciou a participação no projeto, do que aprendeu sobre os programas e como vem usando o computador.

Estou fazendo essas observações porque algumas pessoas estão sem entender nada... e não é justo, concorda? 
Assim como eu, cada um deles está querendo vibrar com as conquistas, ajudar nos novos desafios.

Mas só podemos fazer isso se soubermos do que se trata.

Certo?

Então, vamos em frente! E tomara que, daqui por diante, com uma comunicação mais freqüente, pois uma mensagem tão antiga acabou gerando esse espaço muito grande e nos deixando meio "boiando" na história!

Beijocas!

Adri

Orientadora RJ-PR

$>$ DRI

$>$

$* * *$

Mensagem 868

CABEÇALHO: De: "M. G. M.

Data: Ter Ago 7, 2001 9:38 pm

Assunto: J. P.

MENSAGEM: J. recebi atraves da lista a mensagem e em uma parte comentava que assumir um laboratorio com um $\mathrm{n}^{\mathrm{o}} \mathrm{x}$ de computadores, mas não desanime já estou nesta função a 2 anos e te digo no começo para mim foi dificil, pois como você não tenho computador e quando cheguei também não sabia de nada. Mas agora já passadas as dificuldades e agora estou aqui na lista, contando um pouco de minha jornada até aqui( entre ajudar os alunos do turno da tarde e da noite e num espaço de tempo curto ainda configurar todas as máquinas que depois de um tempo fica até monotono fazer).

Mas como tudo tem inicio,meio e fim e a minha jornada esta acabando e agora a minha nova missão é treinar novos monitores poir que estou no $3^{\circ}$ ano e no ano que vem estou saindo.

E você quais funções exerce?

espero resposta!!!

M. G. M.

Porto Alegre/RS

$* * *$

Mensagem 871

CABEÇALHO: De: "Drica"

Data: Ter Ago 7, 2001 11:28 pm

Assunto: Re: [esc2k] Re: comemoracção

MENSAGEM: Bem eu não sou...

Adriana Costa

EE Sapopemba

----- Original Message

From: Ney Mourão <neymourao@...>

To: <esc2k@yahoogroups.com>

Sent: Tuesday, August 07, 2001 1:38 PM

Subject: RE: [esc2k] Re: comemoracção

$>$ Oi, E. 
$>$ N. M.

$>$ Orientador - MG

$* * *$

d) a análise:

Essa teia é bastante simples, pois é uma das menores do subcorpus. Entretanto o entendimento do seu conteúdo ficou bastante prejudicado para os demais assinantes porque o conhecimento de mundo (elemento coesivo de associação) era partilhado apenas por J. P., que inicia a teia e Adri P., integrante da Equipe Gestora do IAS que visitava o CEDOA, escola em que J. P. trabalhava como monitor e estava bastante a par do que acontecia nessa escola.

Por isso, por não conseguir encontrar coerência no que J. P. diz, e não conseguir conectar a mensagem inicial a outras mensagens do fluxo, E.C. envia a mensagem 852, deixando um "pedacinho" da mensagem de J.P. e reiterando, no corpo do seu texto, o nome de Adri. P., a quem a mensagem se encaminha e algumas outras informações como a expressão "a jornada que ela apóia". N.M. também procura um sentido nessas mensagens, e não encontrando, envia a mensagem 854 , corroborando tudo que E. C. tinha dito, deixando parte da mensagem de E.C. para que o leitor possa se situar. Ao deixar parte da mensação, o emissor repete informações, ajudando a manter seu texto coeso.

Adri P. responde em seguida, explicando e situando o leitor na M-855. Nessa mensagem ela ao mesmo tempo em que situa o leitor, ensina como J.P. deve fazer para deixar elementos coesivos na sua mensagem, como utilizando a sua assinatura e identificando o nome da sua escola, município e estado. Em seguida, ela explica que o assunto só havia sido conversado entre eles e não tinha sido tornado público para a lista.

As mensagens 868 e 871 também são bastante interessantes:

M.G.M. envia a mensagem 868, demonstrando que agora já entendeu a história e também é monitor na escola em que estuda, conta um pouco da sua experiência e pede para que J.P. conte na lista, um pouco do que vem fazendo, para que M.G.M. possa auxiliá-lo; uma outra Adri envia a mensagem 871. Percebe-se que ela não entende bem o que está acontecendo e simplesmente diz que não é para ela a mensagem 851. Ela ainda não deve ter lido a mensagem de Adri. P., embora aquela mensagem já tenha sido enviada a algumas horas. 


\section{Exemplo 2:}

Na teia 2, "curiosidades" temos um bom exemplo de paralelismo. Ela é iniciada na M 857, onde J.R.P. diz que trará para a lista algumas curiosidades de uma lista telefônica. $\mathrm{Na}$ seqüência ela usa de paralelismo e manda, quase diariamente, uma mensagem com 3 dessas curiosidades. Ao enviar as mensagens 858 - Curiosidades 1-2-3, 882 - Curiosidades 4-5-6, 940 - Curiosidades 7-8-9,... 1945 - 52-53-54, usando esse tipo de construção, ajuda o leitor que vem acompanhando essa conversa, formando um elo de ligação entre essas mensagens e formando uma grande teia (deixo de reproduzir o conteúdo dessas mensagens porque essa teia foi citada nas páginas 70 e 77, comentada nas páginas 81 e 104, cf anexo p.147-151).

\section{Exemplo 3:}

Ainda nessa teia há o fio gerado pela curiosidade número 5 , onde as mensagens são associadas por seleção de palavras semanticamente próximas (deixo de reproduzir o conteúdo das mensagens porque ele foi reproduzido nas páginas 110 a 113). Entretanto farei um levantamento de alguns vocábulos e expressões que nas mensagens estão relacionados à história de Roma, e indicarei o número da mensagem:

Rômulo (M 882), civilização (M 883), fundador de Roma (M 885), irmão (M 886), Rômulo e Remo, gêmeos (M 888), Calígula (M 899), colocou fogo em Roma (M 887), amamentou Rômulo (M 887), Imperador Nero (M 897), Latim, mater (M 901) entre outros.

\section{Exemplo 4}

O nó nos fios ou nas teias também são elementos coesivos. Darei dois exemplos de nó, um que agrupa duas teias e outro que agupa dois fios:

a) $\mathrm{Na}$ teia 1 há a mensagem 2090 (cf anexo p. 140-144, reproduzido na p. 32 e comentado na p. 70), que funciona como "nó" por juntar duas teias inicialmente autônomas. Nessa mensagem, uma integrante da Equipe Gestora do IAS convida todos a participar do fórum que irá acontecer no município de Rio das Ostras/RJ e no mesmo dia haverá um fórum em Novo Hamburgo/RS e os dois grupos se encontrarão virtualmente em um chat. 
b) Na Teia 6, cujo título é "Estamos famosos" há a mensagem 1500, reproduzida abaixo, e que funciona como "nó" por juntar dois fios. Nessa mensagem L.M.M.A. retoma alguns elementos do tópico em curso: duas reportagens, uma na TV Verdes Mares e outra na Revista Isto É e introduz um novo tópico, um encontro de escolas parceiras no município de Meruoca/CE:

\begin{abstract}
Mensagem 1500
Olá gente

"São muitas emoções"... Ontem saiu nossa reportagem na TV Verdes Mares - CE, hoje recebemos a Revista Isto É, e hoje nossos protagonistas estao participando do I Encontro entre escolas parceiras do Ceará em Meruoca-CE. Três alunos e uma professora viajaram ontem para representar mais uma vez a escola nesse intercâmbio cultural. Voltarão no sábado com muitas novidades, com certeza.
\end{abstract}

Abraços

Marilac - EEFM Estado da Bahia - Crato-CE

\title{
Exemplo 5
}

A mensagem 942, reproduzida na p. 112, é um exemplo de paráfrase. Adr. P. retoma rapidamente o que já foi dito em vários e-mails para situar melhor M. que avisa ao grupo na mensagem 907 que deixou de abrir sua caixa postal por um dia e sente-se "baratinada".

\section{Exemplo 6}

A mensagem 831, reproduzida na p. 90, possui um exemplo de repetição propriamente dita. M. P. envia sua mensagem, tentando auxiliar M. e F. , deixa parte da mensasgem anterior, que é marcada automaticamente com o símbolo ">" . Esse elemento coesivo é utilizado largamente pelos assinantes.

Esses são apenas alguns exemplos retirados da lista. Há muito mais. Entretanto, acredito que a contribuição desse capítulo foi mostrar os elementos coesivos específicos do fluxo da lista de discussão. McCleary (1996:172) observa que apesar dos avanços tecnológicos, a conversação escrita assincrônica ainda está longe de ter encontrado uma forma física adequada para representar os textos nela desenvolvidos. Passados mais de dez anos, percebo que as inovações do software ainda não deram conta de todos os problemas, e ainda não temos uma situação ideal. Foram muitos os momentos em que eu lia uma mensagem e 
não tinha idéia de qual teia ela pertencia, porque o assinante, sem a preocupação da pesquisadora, dizia algo que fazia sentido naquele momento, enquanto a conversa se desenvolvia. Li e reli essas quase 800 mensagens, buscando algum elemento, alguma pista para que me auxiliasse a encaixá-la na teia correta. Depois de acreditar que as 37 teias já estavam montadas e tendo memorizado os diversos tópicos, ainda mudei algumas mensagens de lugar.

Termino o capítulo com algumas palavras de McCleary (1996:172):

A primeira tarefa do leitor de uma lista é uma que é pouco normal nos eventos discursivos comuns: é de "achar o texto" ao qual pertence o enunciado sob inspeção. (...) Como foi dito, algumas mensagens foram escritas para serem relativamente autônomas, mas muitas não: são turnos em um diálogo de muitas vozes e dependem do seu contexto para serem apreciadas - um contexto que não está fixado em nenhum lugar. 


\section{CONCLUSÃO}

Com a análise apresentada, encerro a pesquisa de mestrado que me propus fazer, acreditando ter cumprido os objetivos propostos, a saber:

a) o social, disponibilizando para a sociedade as experiências de vida com o exemplo da mudança da minha prática pedagógica e de alguns assinantes da lista, entre eles um professor e uma aluna;

b) o educacional, oferecerendo, por meio da narrativa da formação de um Grupo de Discussão on-line, denominado: "Lista provisória dos participantes do programa 'Sua escola a 2000 por hora" até seu formato atual e da noção de "Educação para o desenvolvimento humano", subsídios para a reflexão de profissionais de Educação, interessados na melhoria da qualidade de ensino em escolas públicas. Há um conhecimento que depende da capacidade do profissional para apreciar o valor das suas decisões e as conseqüências que dela decorrem. Esta proposta salienta o aspecto da prática como fonte de conhecimento por meio da experimentação e reflexão, como momento privilegiado de integração de competências. $\mathrm{O}$ professor pode e deve ser o elemento mediador e facilitador do conhecimento de seus alunos. Para tanto é necessário que ele se instrumentalize com as tecnologias contemporâneas e reflita sobre sua prática pedagógica, percebendo que o ato pedagógico é único. É preciso que aprenda a enfrentar o imprevisto e seja capaz de ter iniciativa, transformando as disciplinas e o conhecimento dos alunos;

c) o acadêmico, contribuindo, por meio da análise do funcionamento desse grupo, com elementos para reflexão de certos aspectos, podendo-se destacar que o fenômeno da interação não é exclusivo da linguagem natural, ocorrendo também nas linguagens artificiais, como nos meios digitais. Nesse sentido, compartilho da idéia de alguns autores e entendo, com base no conceito bakhtiniano de esferas, que o contexto digital é um ambiente potencializador de linguagens artificiais, dando início aos gêneros digitais. Desse modo, a lista de discussão é entendida como gênero emergente nas tecnologias digitais.

Na montagem do corpus, pude observar as seguintes características: a formação de uma comunidade de discurso, com valores comuns entre seus membros, como grande espírito de solidariedade e noção de pertencimento; distribuição discrepante entre a participação de alguns em relação a outros. Esse fenômeno foi percebido com clareza por McCleary (1996) e 
Souza (2003). Além disso, grande parte da comunidade permanece calada, sendo denominada de lurkers.

A análise do conceito de "conversação eletrônica", tanto em chats quanto em listas, em comparação com a conversação natural mostrou que a interação polilógica é mais complexa que a interação diádica. Quanto maior o número de participantes em uma conversa natural, maiores são os problemas de negociação entre os falantes. Isso não ocorre na conversação eletrônica, pois não há assaltos, truncamentos ou passagens de turno sem consentimento, podendo os emissores entrarem na conversa em curso a qualquer momento, já que o estado interativo nas listas está sempre aberto. Entretanto, algumas características são próprias da lista, pois a dimensão temporal é dilatada, sendo possível uma demora de dias entre uma pergunta e sua respectiva resposta. Isso não ocorre nos chats, pois a conversação lá é síncrona como na conversação face a face. O que aproxima os chats e as listas de discussão é que ambos são gêneros conversacionais baseados no diálogo (no sentido socrático do termo), sendo ambos concepcionalmente falados, mas realizados de forma escrita.

Sobre as teias, McCleary afirma (1996:196) ser viável a análise de todo o discurso de uma lista em teias tópicas autônomas, cada uma com começo e fim. Isso foi demonstrado com a produção do anexo, pois, por mais ramificações que as teias possam gerir, elas acabam sempre se esgotando. As teias se propagam pelas ligas coesivas dentro da produção da lista. Assim, é possível estabelecer com exatidão o começo de uma teia: é a primeira ocasião em que um fato é mencionado. Se um mesmo fato é mencionado tempos depois, mas sem nenhuma referência à menção anterior, trata-se de outra teia.

Para entender o fluxo estrutural e semântico da lista, o assinante precisa usar elementos coesivos afim de articular cada um dos textos em processo. Alguns elementos que permitem as relações textuais, encontram-se em textos em geral, como a reiteração, a associação, a conexão e seus desdobramentos. Outros elementos são específicos da lista, como cabeçalho (rótulo de assunto, data e horário de envio da mensagem e procedência) e a mensagem resposta.

Creio que a pesquisa e as reflexôes que ela me proporcionou, além de cumprirem a proposta e os objetivos da presente dissertação, podem abrir sugestões e novas reflexões sobre o tema, levando-se em conta a exigüidade e necessidade de estudos específicos e mais aprofundados sobre listas de discussão. 


\section{REFERÊNCIAS BIBLIOGRÁFICAS}

ANDRÉ, Simone \& COSTA, Antônio Carlos da. Educação para o desenvolvimento humano. São Paulo: Saraiva: Instituto Ayrton Senna, 2004.

ANTUNES, Irandé Costa. Lutar com palavras: coesão e coerência. São Paulo: Parábola Editorial, 2005.

ARAÚJO, Júlio César. A conversa na web: o estudo da transmutação em um gênero textual. In: MARCUSCHI, Luiz Antônio, XAVIER, Carlos dos Santos (orgs.) Hipertexto e gêneros digitais: novas formas de construção do sentido. Rio de Janeiro: Lucerna, 2004.

BAKHTIN, Mikhail. Estética da criação verbal. São Paulo: Martins Fontes, 2003.

BARROS, Diana Luz Pessoa de. Entre a fala e a escrita: algumas reflexões sobre as posições intermediárias. In: PRETI, Dino (org.) Fala e escrita em questão. São Paulo: Humanitas/FFLCH/USP, 2000.

BARROS, Kazue Saito Monteiro. Características organizacionais de aulas pela Internet. In: URBANO, Hudinilson et ali (orgs). Dino Preti e sus temas: oralidade, literatura, mídia e ensino. São Paulo: Cortez, 2001.

BETTO, Frei. (s/d) A escola dos meus sonhos. Disponível em: $<$ http://www.escola2000.org.br/> Acesso em: 03/12/2006.

BOCK, Ana Maria Bahia; FURTADO, Odair. e TEIXEIRA, Maria de Lourdes. Psicologias: uma introdução ao estudo de psicologia. 8 ed. São Paulo: Saraiva, 1995.

BRANDÃO, Helena Hatsue Nagamine. Introdução à análise do discurso, 8. ed. São Paulo: Editora da UNICAMP, 2002. 
BRANDÃO, Helena Hatsue Nagamine (org.). Gêneros do discurso na escola: mito, conto, cordel, discurso político, divulgação científica. São Paulo: Cortez, 2000.

BRASIL é lider mundial em uso de internet, diz pesquisa. O Estado de S. Paulo. 22 julho 2005. Disponível em: <http://www.estadao.com.br $>$ Acesso em 22 jul. 2005 .

CARPANEZ, Juliana. Apesar do crescimento, inclusão digital continua sendo desafio para o Brasil. Folha Online. São Paulo, 18 dez. 2004. Disponível em $<\underline{\text { http://www1.folha.uol.com.br }}$ $>$ Acesso em 15 ago. 2005.

CHAVES, Eduardo. Educação orientada para competências e currículo centrado em

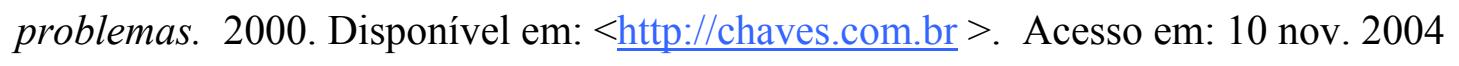

CHAVES, Eduardo. Concepção de aprendizagem e projetos de aprendizagem na visão do programa "sua escola a 2000 por hora" Disponível em: $<\underline{\text { http://www.escola2000.org.br/pesquise/texto/textos_art.aspx?id=74> }}$. Acesso: 30/03/07.

DELORS, Jacques et al. Educação um tesouro a descobrir. Relatório para a UNESCO da Comissão Internacional sobre Educação no Século XXI. São Paulo: Cortez, 1998.

ERCÍLIA, Maria. A internet. São Paulo: Publifolha, 2000.

ERICKISON, Thomas. Persistent conversation. 1999. Disponível em: http://www.pliant.org/personal/Tom_Erickson/. Acesso em: 30/03/07.

FÁVERO, Leonor Lopes. O tópico conversacional. In: PRETI, Dino (org.). Análise de textos orais. São Paulo: FFLCH/USP, 1993.

FÁVERO, Leonor Lopes; AQUINO, Zilda Gaspar Oliveira de. A dinâmica das interações verbais: o trílogo. In: PRETI, Dino (org.). Interação na fala e na escrita. São Paulo: Humanitas/FFLCH/USP, 2002. 
GALEMBECK, Paulo de Tarso . O turno conversacional. In: PRETI, Dino (org.). Análise de textos orais. São Paulo: FFLCH/USP, 1993.

GIL, Antônio Carlos. Como elaborar projetos de pesquisa. 3. ed. São Paulo: Atlas, 1996.

HILGERT, José Gaston. A construção do texto "falado" por escrito: a conversação na internet. In. PRETI, Dino (org.) Fala e escrita em questão. São Paulo: Humanitas/ FFLCH/USP, 2000.

KERBRAT-ORECCHIONI, Catherine. Introducing polylogue. Journal of pragmatics. Holland: Elsevier B.V. n. 36, p. 1-24, 2004.

KERBRAT-ORECCHIONI, Catherine. Análise da conversação: princípios e métodos. São Paulo: Parábola Editorial, 2006.

KOCH, Ingedore Grunfeld Villaça. Argumentação e linguagem. 8. ed. São Paulo: Cortez, 2002.

$\mathrm{KOCH}$, Ingedore Grunfeld Villaça. Introdução à lingüistica textual: trajetória e grandes temas. São Paulo: Martins Fontes, 2004.

KOCH, Ingedore Grunfeld Villaça. A coesão textual. 20 ed. São Paulo: Contexto, 2005.

$\mathrm{KOCH}$, Ingedore Grunfeld Villaça. Especifidade do texto falado. In: JUBRAN, Clélia Cândida Spinardi; KOCH, Ingedore Grunfeld Villaça (orgs.) Gramática do português culto falado no Brasil. Campinas/Editora da Unicamp, 2006.

KOCH, Ingedore Grunfeld Villaça; BENTES, Anna Christina, CAVALCANTE; Mônica Magalhães. Intertextualidade: diálogos possíveis. São Paulo: Cortez, 2007. 
KOMESU, Fabiana Cristina. Oralidade e escrita nas páginas eletrônicas pessoais da internet. GEL - Estudos Lingüísticos, Assis: Unesp. v. 29, p. 590-595, 2000.

KOMESU, Fabiana Cristina. Gêneros do discurso e a atividade de escrita nas páginas eletrônicas pessoais da internet. . GEL - Estudos Lingüísticos, Marília: Unesp. v. 30, p. 590$595,2001$.

LITTO, Frederic Michael. Aprendizagem Profunda e Aprendizagem de Superficie. Disponível em: $<$ http://www.futuro.usp.br/ > Acesso em:03/12/2006.

MACHADO, Irene. Gêneros digitais e suas fronteiras na cultura tecnológica. In: Educação \& Tecnologia. (Periódico técnico científico dos programas de pós-graduação em tecnologia dos $\begin{array}{lllll}\text { CEFETs } & - & \mathrm{PR} / \mathrm{MG} / \mathrm{RJ}) . & \text { p. } & 117-128\end{array}$

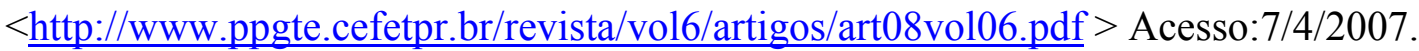

MARCUSCHI, Luiz Antônio. Da fala para a escrita: atividades de retextualização. 2. ed. São Paulo: Cortez, 2001.

MARCUSCHI, Luiz Antônio. Gêneros textuais emergentes no contexto da tecnologia digital. In: MARCUSCHI, Luiz Antônio, XAVIER, Carlos dos Santos (orgs.) Hipertexto e gêneros digitais: novas formas de construção do sentido. Lucerna: Rio de Janeiro, 2004.

MARCUSCHI, Luiz Antônio. Análise da conversação. 5. ed. São Paulo: Ática, 2006.

MARCUSCHI, Luiz Antônio; XAVIER, Antônio Carlos dos Santos (orgs.). Hipertexto e gêneros digitais: novas formas de construção do sentido. Rio de Janeiro: Lucerna, 2004.

MARCOCCIA, Michel. On-line polylogues: conversation structure and participation framework in internet newsgroups. Journal of pragmatics. Holland: Elsevier B.V. n. 36, p. 115-145, 2004. 
MARINO, Eduardo. Manual de avaliação de projetos sociais. 2 ed. São Paulo: Saraiva: Instituto Ayrton Senna, 2003.

MARQUESI, Sueli Cristina. Interação e subjetividade no ensino via Internet. In: URBANO, Hudinilson et ali (orgs.). Dino Preti e seus temas: oralidade, literatura, mídia e ensino. São Paulo: Cortez, 2001.

McCLEARY, Leland Emerson . Aspectos de uma modalidade de discurso mediado por computador. São Paulo. Tese (Doutorado em Lingüística) - Faculdade de Filosofia, Letras e Ciências Humanas, Universidade de São Paulo, 1996.

NADER, Valéria Holzmann. A interação virtual em diálogos da Internet: novas possibilidades para a análise do discurso. São Paulo. Dissertação (Mestrado em Filologia e Língua Portuguesa) - Universidade de São Paulo, 2001.

OLIVEIRA, João Batista Araujo e. A pedagogia do sucesso: uma estratégia política para corrigir o fluxo escolar e vencer a cultura da repetência. São Paulo: Saraiva: Instituto Ayrton Senna, 1999.

PAIVA, Vera Lúcia Menezes de Oliveira e. E-mail: um novo gênero textual. In: MARCUSCHI, Luiz Antônio, XAVIER, Carlos dos Santos Xavier (orgs.) Hipertexto e gêneros digitais: novas formas de construção do sentido. Lucerna: Rio de Janeiro, 2004.

RODRIGUES, André Figueiredo. Como elaborar referência bibliográfica. 4. ed. São Paulo: Associação Editorial Humanitas, 2004.

RODRIGUES, André Figueiredo. Como elaborar citações e notas de rodapé. 2. ed. São Paulo: Associação Editorial Humanitas, 2005.

RODRIGUES, Ângela Cristina Souza. Língua falada e língua escrita. In: PRETI, Dino (org.). Análise de textos orais. São Paulo: FFLCH/USP, 1993. 
SEN, Amartya Kumar. Desenvolvimento como liberdade. São Paulo: Companhia das Letras, 2000.

SENNA, Instituto Ayrton. Sua escola a 2000 por hora. $<$ http://www.escribe.com/education/escola2000/index.html $>$. Acesso em 10 jan. 2003.

SEVERINO, Antônio Joaquim. Metodologia do trabalho cientifico. 20. ed. São Paulo: Cortez, 1996.

SILVA, Vítor Manuel de Aguiar e. Teoria da literatura. 3 ed. Coimbra:Almedina, 1973.

SOARES, Magda. Alfabetização e letramento. São Paulo: Contexto, 2003.

SOUZA, Paulo Rogério de. E-mail de apresentação pessoal e identidade nas comunidades online. Dissertação ( Mestrado em Língua Inglesa e Literaturas Inglesa e Norte-Americana). São Paulo: FFLCH, 2003.

SOUZA, Paulo Rogério de. Comunicação digital: mistura de modalidades lingüísticas? In: LIMA, Maria Cecília (org.) Domínios de linguagem I: práticas pedagógicas. São Paulo: Yangraf-graf e ed, 2002.

UM em cinco brasileiros adultos já utilizou a Web. 8 jun. 2004. Disponível em: $<$ http://informatica.terra.com.br>. Acesso em: 14 ago. 2005

URBANO, Hudinilson. Oralidade na literatura: o caso Rubem Fonseca. São Paulo: Cortez, 2000.

URBANO, Hudinilson. Uso e abuso da linguagem da internet. Informe: informativo da Faculdade de Filosofia, Letras e Ciências Humanas - USP, São Paulo, nova série n 24, p. 13, setembro, 2001. 
URBANO, Hudinilson. Usos da linguagem verbal. In: PRETI, Dino (org.) Oralidade em diferentes discursos. São Paulo: Associação Editorial Humanitas, 2006. 


\section{ANEXO}

As teias do subcorpus

Em seguida o leitor encontrará todas as teias diagramadas que formam o subcorpus. Elas foram numeradas em ordem decrescente de número de mensagens. Em seguida aparece o título da teia, cuja escolha está relacionada ao assunto abordado. Incluí o número total de mensagens, período de duração da teia e o número de participantes ativos (lembrando que todos os assinantes são participantes, mesmo que de forma passiva, como os lurkers, pois em geral lêem as mensagens).

Em seguida há uma síntese dos assuntos abordados na teia (reproduzir o conteúdo as mensagens tornaria o trabalho inviável). Por isso, no corpo do trabalho foram reproduzidas as mensagens mais pertinentes, em geral de forma integral, para tornar a análise mais clara. Quando a mesma mensagem era citada, comentada ou analisada sob outro aspecto, em algum outro ponto do trabalho, eu apenas fazia menção ao número do item e a página em que a mensagem estava reproduzida, para que o leitor pudesse encontrá-la facilmente.

Gostaria de lembrar ao leitor que as 37 teias que constituem o subcorpus não foram as únicas do período. Há ainda 105 pequenas teias, das quais 52 compostas de apenas 1 mensagem; 33 compostas por 2 mensagens; 14 compostas por 3 mensagens e 6 compostas por 4 mensagens. Como o objetivo da pesquisa era analisar as interações polilógicas, desconsiderei as teias com menos de 3 participantes. Desconsiderei também as teias com menos de 5 mensagens pelo baixo índice de interatividade encontrado.

Cabe lembrar que as teias foram diagramadas de duas maneiras distintas em virtude do tamanho apresentado:

Nas teias de números 1 a 8 o diagrama foi composto apenas com o número de cada mensagem (lembrando que foi mantida a numeração automática do software). Em seguida foi criado uma tabela em que aparecem todas as informações do cabeçalho: número da mensagem; nome do emissor (abreviado); data e horário de envio da mensagem e assunto.

Nas teias de números 9 a 36 o diagrama foi feito com o cabeçalho da mensagem. 


\section{T e i a 1}

Título: IV Fórum de alunos em Novo Hamburgo/RS , em Rio das Ostras/RJ, em Capão da Canoa/RS e Fórum Infanto Juvenil em Canela/RS

Essa teia é formada por 115 mensagens e 39 participantes, no período de 8 de agosto a 29 de outubro.

São dois os pontos de partida dessas mensagens. A primeira delas é a respeito de um fórum que acontecerá em Novo Hamburgo/RS. Discute-se como e onde acontecerá o fórum e as principais atividades. O segundo ponto de partida é um outro fórum que acontecerá em no município de Rio das Ostras-RJ. Em seguida há uma série de mensagens cujo assunto é a organização do encontro. Em determinado momento surgem duas mensagens da equipe técnica do IAS falando sobre os dois encontros que em parte acontecerão simultaneamente e haverá interação via chat entre os participantes dos dois fóruns. Em seguida surgem várias mensagens mencionando os dois encontros e a teia termina com mensagens de avaliações dos encontros. No desenrolar da teia também são mencionados dois fóruns que acontecerão nos municípios de Canela e Capão da Canoa, ambos no RS.

Na página seguinte o leitor encontrará a teia diagramada: 
Teia 1 - IV Fórum de alunos em Novo Hamburgo/RS , em Rio das Ostras/RJ, em Capão da Canoa/RS e Fórum Infanto Juvenil em Canela/RS

Observações:

a) as mensagens 2091 e 2090, embora não sejam idênticas, ou seja, não se trata de uma mesma mensagem enviada duas vezes, traz conteúdo similar.

Ambas são enviadas pela equipe técnica do IAS e enquanto na M-2090 é enfatizado o encontro em Rio das Ostras, na M-2091 é enfatizado o encontro em Novo Hamburgo

Nesse encontro houve uma reunião virtual de troca de experiências: um chat às $15 \mathrm{~h}$, pelo site do Programa.

Essas duas mensagens formam o primeiro nó (elo de ligação entre duas teias);

b) as mensagens de 2166 a 2170 entraram no grupo com aviso de que o e-mail utilizado não estava cadastrado na lista. Por isso, o assinante M.V.B. encaminha esse conteúdo nas mensagens de 2172 a 2179;

c) as mensagens 1877 e 1878, assim como as mensagens 2131 e 2132 são mensagens enviadas duas vezes.
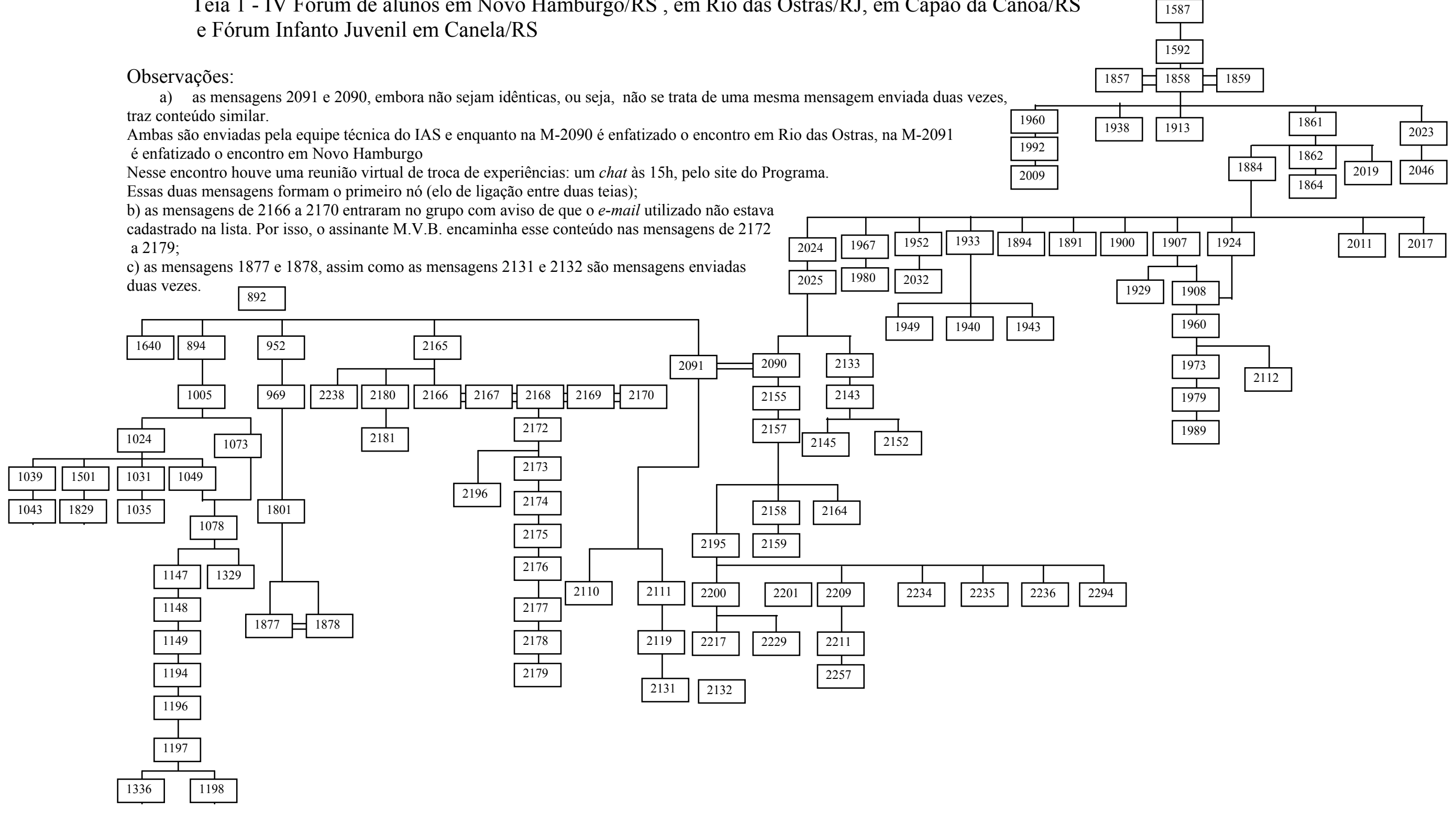
Em seguida (e nas duas próximas páginas) apresento uma tabela com todas as informações do cabeçalho da teia 1, pois não foi possível inserí-las no diagrama.

\begin{tabular}{|c|c|c|c|c|}
\hline & Mensagem & De & Data & Assunto \\
\hline 1 & 892 & VL & Qua Ago 8, 2001 8:13 pm & IV Fórum de Alunos do Rs \\
\hline 2 & 894 & MVB & Qua Ago 8, 2001 9:41 pm & IV Forum de Alunos do Rs \\
\hline 3 & 952 & MPOA & Qui Ago 9, 2001 7:25 pm & IV Fórum Cultural de Alunos \\
\hline 4 & 969 & $\mathrm{~J}$ & Sex Ago 10, 2001 12:08 am & Re: [esc2k] IV Fórum Cultural de Alunos \\
\hline 5 & 1005 & RVM & Sáb Ago 11, 2001 7:48 pm & Re: [esc2k] IV Forum de Alunos do Rs \\
\hline 6 & 1024 & MVB & Dom Ago 12, 2001 11:03 am & Para Ricardo Martins \\
\hline 7 & 1031 & RVM & Dom Ago 12, 2001 5:29 pm & Re: [esc2k] Para Ricardo Martins \\
\hline 8 & 1035 & MVB & Dom Ago 12, 2001 9:45 pm & Para Ricardo Martins \\
\hline 9 & 1039 & GLS & Seg Ago 13, 2001 8:20 am & Re: [esc2k] Para Ricardo Martins \\
\hline 10 & 1043 & RVM & Seg Ago 13, 2001 9:51 am & Re: [esc2k] Para Ricardo Martins \\
\hline 11 & 1049 & LAMG & Seg Ago 13, $20013: 52 \mathrm{pm}$ & $\begin{array}{l}\text { Re: [esc2k] Escolas com surdos [Era: } \\
\text { Para Ricardo Martins] }\end{array}$ \\
\hline 12 & 1073 & CAN & Ter Ago 14, 2001 12:07 pm & Re: [esc2k] IV Forum de Alunos do Rs \\
\hline 13 & 1078 & RVM & Ter Ago 14, 2001 2:04 pm & Re: [esc2k] IV Forum de Alunos do Rs \\
\hline 14 & 1147 & MPOA & Qui Ago 16, 2001 6:29 pm & Fóruns, como são e podem ser? \\
\hline 15 & 1148 & jb & Qui Ago 16, 2001 6:29 pm & HELP para THAIS e todos da rede \\
\hline 16 & 1149 & MPOA & Qui Ago 16, 2001 6:38 pm & help \\
\hline 17 & 1194 & MPOA & Sex Ago 17, 2001 8:22 pm & Motivação IV Fórum \\
\hline 18 & 1196 & GLS & Sex Ago 17, 2001 8:31 pm & Re: [esc2k] Motivação IV Fórum \\
\hline 19 & 1197 & MPOA & Sex Ago 17, 2001 8:37 pm & Re: [esc2k] Motivação IV Fórum \\
\hline 20 & 1198 & GLS & Sex Ago 17, 2001 8:50 pm & Re: [esc2k] Motivação IV Fórum \\
\hline 21 & 1329 & RVM & Qua Ago 22, 2001 1:44 pm & Fw: Encontro de Surdos em capão \\
\hline 22 & 1336 & MM & Qua Ago 22, 2001 9:23 pm & IV Fórum \\
\hline 23 & 1501 & RVM & Sex Ago 31, 2001 12:24 am & Re: Surdez - Relato de experiência \\
\hline 24 & 1587 & LS & Qua Set 5, 2001 9:53 pm & Encontro Rio das Ostras \\
\hline 25 & 1592 & drip & Qui Set 6, 2001 2:39 am & Re:[esc2k] Encontro Rio das Ostras \\
\hline 26 & 1640 & MVB & Dom Set 9, 2001 9:16 pm & Fórum Infanto Juvenil em Canela \\
\hline 27 & 1801 & MM & Qua Set 19,2001 10:32 pm & Fórum de Alunos FWD Antonio Vieira \\
\hline 28 & 1829 & MRC & Sáb Set 22, $20019: 56$ pm & $\begin{array}{l}\text { Re: [esc2k] Re: Surdez - Relato de } \\
\text { experiência }\end{array}$ \\
\hline 29 & 1857 & CMAA & Seg Set 24, $20015: 29 \mathrm{pm}$ & (Sem assunto) \\
\hline 30 & 1858 & CMAA & Seg Set 24, $20015: 39 \mathrm{pm}$ & encontro em rio das ostras \\
\hline 31 & 1859 & CMAA & Seg Set 24, $20016: 18 \mathrm{pm}$ & $\begin{array}{l}\text { ENCONTRO EM RIO DAS OSTRAS - } \\
\text { RJ }\end{array}$ \\
\hline 32 & 1861 & MIG & Seg Set 24, 2001 10:12 pm & $\begin{array}{l}\text { RE: [esc2k] ENCONTRO EM RIO DAS } \\
\text { OSTRAS - RJ/Programacao }\end{array}$ \\
\hline 33 & 1862 & GLS & Seg Set 24, 2001 11:19 pm & $\begin{array}{l}\text { Re: [esc2k] ENCONTRO EM RIO DAS } \\
\text { OSTRAS - RJ/Programacao }\end{array}$ \\
\hline 34 & 1864 & MIG & Seg Set 24, 2001 11:41 pm & $\begin{array}{l}\text { RE: [esc2k] ENCONTRO EM RIO DAS } \\
\text { OSTRAS - RJ/Programacao }\end{array}$ \\
\hline 35 & 1877 & MM & Ter Set 25, 2001 7:57 pm & Fórum \\
\hline 36 & 1878 & MM & Ter Set 25, 2001 7:58 pm & Fórum FWD antonio vieira \\
\hline 37 & 1884 & CMAA & Qua Set 26, $20013: 12 \mathrm{pm}$ & Encontro de Rio das Ostras: O LUAL \\
\hline 38 & 1891 & GLS & Qua Set 26, $20016: 54 \mathrm{pm}$ & $\begin{array}{l}\text { Re: [esc2k] Encontro de Rio das Ostras: } \\
\text { O LUAL }\end{array}$ \\
\hline 39 & 1894 & SL & Qua Set 26, 2001 9:26 pm & $\begin{array}{l}\text { Re: [esc2k] Encontro de Rio das Ostras: } \\
\text { O LUAL }\end{array}$ \\
\hline 40 & 1900 & Md & Qui Set 27, 2001 12:46 am & $\begin{array}{l}\text { Re: [esc2k] Encontro de Rio das Ostras: } \\
\text { O LUAL }\end{array}$ \\
\hline 41 & 1907 & CMAA & Qui Set 27, $20018: 36 \mathrm{pm}$ & $\begin{array}{l}\text { Encontro em Rio das Ostras: } \\
\text { PALESTRA DE ABERTURA }\end{array}$ \\
\hline
\end{tabular}




\begin{tabular}{|c|c|c|c|c|}
\hline 42 & 1908 & $\overline{L S}$ & Qui Set 27, 2001 10:31 pm & $\begin{array}{l}\text { Re: [esc2k] Encontro em Rio das Ostras: } \\
\text { PALESTRA DE ABERTURA }\end{array}$ \\
\hline 43 & 1913 & ciav & Sáb Set 29, 2001 1:07 pm & $\begin{array}{l}\text { Re:[esc2k] Encontro de Rio das Ostras: } \\
\text { O LUAL }\end{array}$ \\
\hline 44 & 1924 & CMAA & Seg Out 1,2001 7:25 pm & Encontro: OFICINAS I \\
\hline 45 & 1929 & JRP & Ter Out 2, 2001 7:06 pm & $\begin{array}{l}\text { Re: [esc2k] Encontro em Rio das Ostras: } \\
\text { PALESTRA DE ABERTURA }\end{array}$ \\
\hline 46 & 1933 & CMAA & Ter Out 2,2001 8:55 pm & Encontro RO: Refletindo... \\
\hline 47 & 1938 & $\mathrm{mdr}$ & Ter Out 2, $2001 \quad 10: 04 \mathrm{pm}$ & Noticias \\
\hline 48 & 1940 & gab & Qua Out 3, 2001 9:07 am & RE: [esc2k] Encontro RO: Refletindo... \\
\hline 49 & 1943 & ON & Qua Out 3, 2001 10:03 am & Re: [esc2k] Encontro RO: Refletindo... \\
\hline 50 & 1949 & KR & Qua Out 3, 2001 11:10 am & Re: [esc2k] Encontro RO: Refletindo... \\
\hline 51 & 1951 & GLS & Qua Out 3, $20016: 26 \mathrm{pm}$ & Mensagem aos Tocantinenses \\
\hline 52 & 1952 & CMAA & Qua Out 3,2001 8:00 pm & Encontro RO: Teatro \\
\hline 53 & 1960 & CMAA & Qui Out 4,2001 2:34 pm & Encontro das Escolas Parceiras \\
\hline 54 & 1967 & CMAA & Qui Out 4, $20019: 55 \mathrm{pm}$ & Encontro RO: OFICINA \\
\hline 55 & 1973 & ciav & Sex Out 5, 2001 11:41 am & Re:[esc2k] Encontro RO: OFICINA \\
\hline 56 & 1979 & CMAA & Sex Out 5, $20013: 15 \mathrm{pm}$ & Re: Re:[esc2k] Encontro RO: OFICINA \\
\hline 57 & 1980 & CMAA & Sex Out 5, 2001 10:35 pm & Encontro RO: OFICINA III \\
\hline 58 & 1989 & ciav & Sáb Out 6,2001 9:18 am & Re: Re:[esc2k] Encontro RO: OFICINA \\
\hline 59 & 1992 & MIG & Dom Out 6, $2002 \quad 10: 38$ am & $\begin{array}{l}\text { Confusao entre assuntos e conteudos das } \\
\text { mensagens }\end{array}$ \\
\hline 60 & 2009 & $\mathrm{mdr}$ & Ter Out 9, 2001 9:02 am & viagem educativa \\
\hline 61 & 2011 & MIG & Qua Out 9, 2002 10:13 pm & RE: Encontro RO: Espaço \\
\hline 62 & 2017 & EOCC & Qua Out 10,2001 10:36 am & Palestra em Rio das Ostras \\
\hline 63 & 2019 & AGC & Qua Out 10,2001 2:21 pm & Encontro em Rio das Ostras \\
\hline 64 & 2023 & TMSS & Qua Out 10, $20014: 45 \mathrm{pm}$ & Encontro Rio das Ostras \\
\hline 65 & 2024 & ALL & Qua Out 10, $20014: 52 \mathrm{pm}$ & As coisas então fervilhando!! \\
\hline 66 & 2025 & KR & Qua Out 10,2001 5:14 pm & Re: [esc2k] As coisas então fervilhando!! \\
\hline 67 & 2032 & gab & Qui Out 11, 2001 8:30 am & RE: [esc2k] Encontro RO: Teatro \\
\hline 68 & 2046 & CMAA & Qui Out 11, $20017: 19 \mathrm{pm}$ & Triste Resposta \\
\hline 69 & 2090 & $\overline{\mathrm{KR}}$ & Seg Out 15, $20017: 52 \mathrm{pm}$ & $\begin{array}{l}\text { En: Encontro em Rio das Ostras reune } 8 \\
\text { escolas parceiras do Sua Escola a } 2000 \\
\text { por Hora }\end{array}$ \\
\hline 70 & 2091 & AM & Seg Out 15, $20017: 52 \mathrm{pm}$ & $\begin{array}{l}4^{\circ} \text { Forum de Alunos reune cinco escolas } \\
\text { publicas parceiras do Programa Sua } \\
\text { Escola a } 2000 \text { por Hora em Novo } \\
\text { Hamburgo, RS }\end{array}$ \\
\hline 71 & 2110 & eg & Ter Out 16, 2001 12:52 pm & $\begin{array}{l}\text { Re: [esc2k] } \\
4^{\circ} \text { _Forum_de_Alunos_reune_cin } \\
\text { co_escolas_publicas_parceira } \\
\text { s_do_Programa_Sua_Escola_a_2 } \\
\text { 000_por_Hora_em_Novo_Hamburg } \\
\text { o,_RS }\end{array}$ \\
\hline 72 & 2111 & eg & Ter Out 16, 2001 12:52 pm & $\begin{array}{l}\text { Re: [esc2k] } \\
4^{\circ} \text { _Forum_de_Alunos_reune_cin } \\
\text { co_escolas_publicas_parceira } \\
\text { s_do_Programa_Sua_Escola_a_2 } \\
\text { 000_por_Hora_em_Novo_Hamburg } \\
\text { o,_RS }\end{array}$ \\
\hline 73 & 2112 & CMAA & Ter Out 16, $20014: 59 \mathrm{pm}$ & Encontro das Escolas Parceiras \\
\hline 74 & 2119 & LS & Ter Out 16, $20019: 54 \mathrm{pm}$ & Mais detalhes Godo \\
\hline 75 & 2131 & eg & Qua Out 17, 2001 10:00 am & Re: [esc2k] Mais detalhes Godo \\
\hline 76 & 2132 & eg & Qua Out 17, 2001 10:00 am & Re: [esc2k] Mais detalhes Godo \\
\hline 77 & 2133 & CMAA & Qua Out 17, 2001 11:32 am & Fw: Confirmaçao do encontro \\
\hline 78 & 2143 & CMAA & Qua Out 17, 2001 7:05 pm & Escolas confirmadas para o encontro em \\
\hline
\end{tabular}




\begin{tabular}{|c|c|c|c|c|}
\hline & & & & Rio das Ostras \\
\hline 79 & 2145 & EDC & Qua Out 17, 2001 7:00 pm & $\begin{array}{l}\text { Re: [esc2k] Escolas confirmadas para o } \\
\text { encontro em Rio das Ostras }\end{array}$ \\
\hline 80 & 2152 & $\mathrm{mdr}$ & Qui Out 18, 2001 2:01 pm & encontro Rio das Ostras \\
\hline 81 & 2155 & MVB & Sex Out 19, 2001 8:02 am & RJ e RS - Encontro das Escolas Parceiras \\
\hline 82 & 2157 & ON & Sex Out 19, 2001 10:47 am & $\begin{array}{l}\text { [esc2k] RJ e RS - Encontro das Escolas } \\
\text { Parceiras }\end{array}$ \\
\hline 83 & 2158 & RPTS & Sex Out 19, 2001 10:52 am & $\begin{array}{l}\text { Re: [esc2k] RJ e RS - Encontro das } \\
\text { Escolas Parceiras }\end{array}$ \\
\hline 84 & 2159 & ON & Sex Out 19, 2001 11:13 am & $\begin{array}{l}\text { Re: [esc2k] RJ e RS - Encontro das } \\
\text { Escolas Parceiras }\end{array}$ \\
\hline 85 & 2164 & CMAA & Sex Out 19, 2001 3:44 pm & $\begin{array}{l}\text { Re: [esc2k] RJ e RS - Encontro das } \\
\text { Escolas Parceiras }\end{array}$ \\
\hline 86 & 2165 & EEAV & Sex Out 19, $20016: 02 \mathrm{pm}$ & Considerações finais do IV Fórum \\
\hline 87 & 2166 & EEAV & Sex Out 19, $20016: 15 \mathrm{pm}$ & $\begin{array}{l}\text { Fwd: Não foi possível enviar sua } \\
\text { mensagem }\end{array}$ \\
\hline 88 & 2167 & EEAV & Sex Out 19, $20016: 14 \mathrm{pm}$ & noticias 1 \\
\hline 89 & 2168 & EEAV & Sex Out 19, $20016: 15 \mathrm{pm}$ & $\begin{array}{l}\text { Fwd: Não foi possível enviar sua } \\
\text { mensagem }\end{array}$ \\
\hline 90 & 2169 & EEAV & Sex Out 19, $20016: 16 \mathrm{pm}$ & noticias 3 \\
\hline 91 & 2170 & EEAV & Sex Out 19, $20016: 19 \mathrm{pm}$ & noticias 4 \\
\hline 92 & 2172 & MVB & Sex Out 19, 2001 10:43 pm & noticias Forum RS - 1 \\
\hline 93 & 2173 & MVB & Sex Out 19, 2001 10:44 pm & noticias Forum RS - 2 \\
\hline 94 & 2174 & MVB & Sex Out 19,2001 10:45 pm & noticias Forum RS - 3 \\
\hline 95 & 2175 & MVB & Sex Out 19,2001 10:46 pm & noticias Forum RS - 4 \\
\hline 96 & 2176 & MVB & Sex Out 19, 2001 10:47 pm & noticias Forum RS - 5 \\
\hline 97 & 2177 & MVB & Sex Out 19,2001 10:48 pm & noticias - Forum RS - 6 \\
\hline 98 & 2178 & MVB & Sex Out 19,2001 10:49 pm & noticias - Forum RS - 7 \\
\hline 99 & 2179 & MVB & Sex Out 19, 2001 10:50 pm & noticias - Forum RS - 8 \\
\hline 100 & 2180 & MVB & Sex Out 19,2001 10:55 pm & Re: [esc2k-11] Do RS para RJ 2 \\
\hline 101 & 2181 & MVB & Sex Out 19, $2001 \quad 10: 56 \mathrm{pm}$ & $\begin{array}{l}\text { Re: [esc2k-11] IMPRESSÕES SOBRE O } \\
\text { FOORUM }\end{array}$ \\
\hline 102 & 2195 & MIG & Ter Out 22, $2002 \quad$ 10:19 pm & Encontro em Rio das Ostras \\
\hline 103 & 2196 & $\mathrm{PP}$ & Ter Out 23, $2001 \quad 8: 29 \mathrm{am}$ & Re: [esc2k] noticias Forum RS - 1 \\
\hline 104 & 2200 & EOCC & Ter Out 23, 2001 1:22 pm & Ainda Rio das Ostras \\
\hline 105 & 2201 & CMAA & Ter Out 23, 2001 1:41 pm & Encontro de Rio das Ostras \\
\hline 106 & 2209 & APE & Qua Jul 25, 2001 2:23 am & $\begin{array}{l}\text { Re: [esc2k] Encontro em Rio das Ostras ( } \\
\text { Ariane: olá!) }\end{array}$ \\
\hline 107 & 2211 & RPTS & Qua Out 24, 2001 1:45 am & $\begin{array}{l}\text { Re: [esc2k] Encontro em Rio das Ostras ( } \\
\text { Ariane: olá!) }\end{array}$ \\
\hline 108 & 2217 & ciav & Qua Out 24, 2001 11:56 am & Re:[esc2k] Ainda Rio das Ostras \\
\hline 109 & 2229 & $\mathrm{mdr}$ & Qua Out 24, 2001 11:20 pm & Re:[esc2k] Ainda Rio das Ostras \\
\hline 110 & 2234 & MIG & Sex Out 25, 2002 6:13 am & $\begin{array}{l}\text { FW: [esc2k-aluno] Encontro em Rio das } \\
\text { Ostras }\end{array}$ \\
\hline 111 & 2235 & MIG & Sex Out 25, 2002 6:15 am & $\begin{array}{l}\text { FW: [esc2k-aluno] encontros de Rio das } \\
\text { Ostras }\end{array}$ \\
\hline 112 & 2236 & MIG & Sex Out 25, 2002 6:16 am & $\begin{array}{l}\text { FW: [esc2k-aluno] encontros de Rio das } \\
\text { Ostras }\end{array}$ \\
\hline 113 & 2238 & rere & Qui Out 25, 2001 9:09 am & Meus parabéns! \\
\hline 114 & 2257 & APE & Qua Jul 25, 2001 12:14 pm & $\begin{array}{l}\text { Re: [esc2k] Encontro em Rio das Ostras ( } \\
\text { Ariane: olá!) }\end{array}$ \\
\hline 115 & 2294 & TMSS & Seg Out 29, $20013: 30 \mathrm{pm}$ & Certificados Rio das Ostras \\
\hline
\end{tabular}




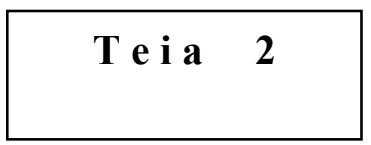

Título: Curiosidades

Essa teia é formada por: 114 mensagens e 19 participantes, no período de 7 de agosto a 30 de outubro.

O ponto de partida é a mensagem de uma aluna dizendo que leu em uma lista telefônica algumas curiosidades e gostaria de compartilhá-las com os demais assinantes. Ela divide as curiosidades de três em três e as envia quase que diariamente, durante quase dois meses. Durante esse período, essas mensagens geram várias mensagens respostas com os assinantes comentando algumas curiosidades e gerando alguns fios longos sobre os mais diversos assuntos, mensagens contando outras curiosidades, outras de incentivo e várias brincadeiras. 


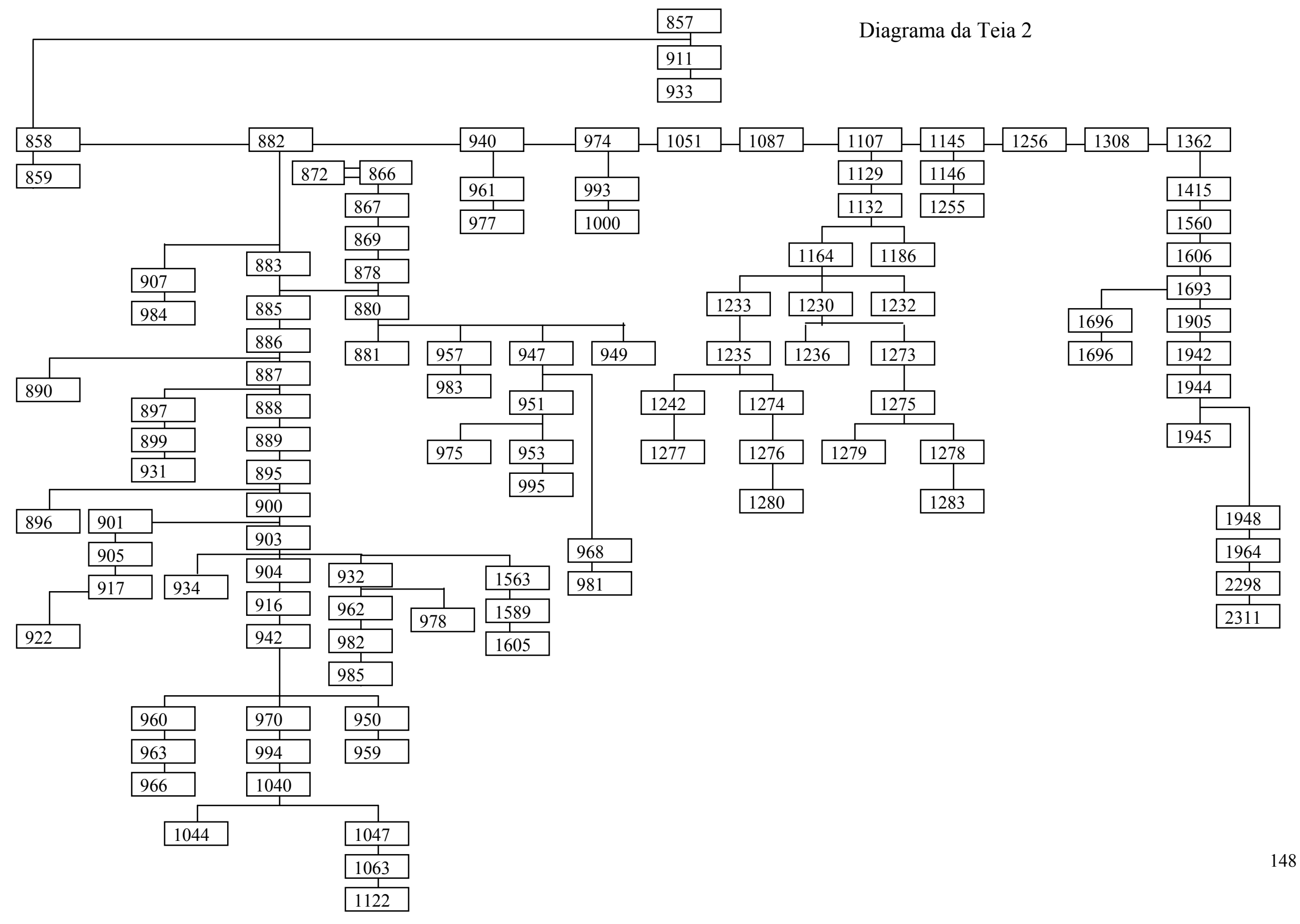


Em seguida (e nas duas próximas páginas) apresento uma tabela com todas as informações do cabeçalho da teia 2, pois não foi possível inserí-las no diagrama.

\begin{tabular}{|c|c|c|c|c|}
\hline & Mensagem & De & Data & Assunto \\
\hline 1 & 857 & J R P & Ter Ago 7, $20015: 18 \mathrm{pm}$ & Curiocidades \\
\hline 2 & 858 & J R P & Ter Ago 7, 2001 5:24 pm & Curiocidades 1-2-3 \\
\hline 3 & 859 & $\mathrm{ON}$ & Ter Ago 7, $20015: 59 \mathrm{pm}$ & Re: [esc2k] Curiocidades 1-2-3 \\
\hline 4 & 866 & MGM & Ter Ago 7, 2001 9:18 pm & Curiosidade \\
\hline 5 & 867 & GLS & Ter Ago 7,2001 9:23 pm & Re: [esc2k] Curiosidade \\
\hline 6 & 869 & MGM & Ter Ago 7, 2001 9:40 pm & Re: [esc2k] Curiosidade \\
\hline 7 & 872 & job & Qua Ago 8, 2001 7:24 am & Re: [esc2k] Curiosidade \\
\hline 8 & 878 & NM & Qua Ago 8, 2001 7:08 am & Re: [esc2k] Curiosidade \\
\hline 9 & 880 & MPOA & Qua Ago 8, $20012: 07 \mathrm{pm}$ & Re: Curiosidade Gaúcha \\
\hline 10 & 881 & JRP & Qua Ago 8, 2001 5:19 pm & Re: [esc2k] Re: Curiosidade Gaúcha \\
\hline 11 & 882 & JRP & Qua Ago 8, $20015: 25 \mathrm{pm}$ & Curiosidades 4-5-6 \\
\hline 12 & 883 & MGM & Qua Ago 8, 2001 5:44 pm & Re:[esc2k] Curiosidades 4-5-6 \\
\hline 13 & 885 & JRP & Qua Ago 8, 2001 6:27 pm & Re:[esc2k] Curiosidades 4-5-6 \\
\hline 14 & 886 & $\mathrm{AP}$ & Qua Ago 8, $20016: 40 \mathrm{pm}$ & Romulo \\
\hline 15 & 887 & RPTS & Qua Ago 8, $20015: 38 \mathrm{pm}$ & Re: Re:[esc2k] Curiosidades 4-5-6 \\
\hline 16 & 888 & ML & Qua Ago 8, 2001 7:25 pm & Re:[esc2k] Romulo \\
\hline 17 & 889 & EOCC & Qua Ago 8, $20017: 35 \mathrm{pm}$ & RE: [esc2k] Romulo \\
\hline 18 & 890 & MPOA & Qua Ago 8, 2001 7:54 pm & Re:[esc2k] Romulo \\
\hline 19 & 895 & EOCC & Qua Ago 8, 2001 10:02 pm & RE: [esc2k] Romulo \\
\hline 20 & 896 & EOCC & Qua Ago 8, 2001 10:03 pm & RE: [esc2k] Romulo \\
\hline 21 & 897 & ML & Qua Ago 8, 2001 10:06 pm & Re: Re:[esc2k] Curiosidades 4-5-6 \\
\hline 22 & 899 & EOCC & Qua Ago 8, 2001 10:14 pm & RE: Re:[esc2k] Curiosidades 4-5-6 \\
\hline 23 & 900 & NM & Qua Ago 8, $20017: 18 \mathrm{pm}$ & RE: [esc2k] Romulo \\
\hline 24 & 901 & EOCC & Qua Ago 8, 2001 10:25 pm & RE: [esc2k] Romulo \\
\hline 25 & 903 & AP & Qua Ago 8, 2001 10:38 pm & Re: [esc2k] Romulo \\
\hline 26 & 904 & GLS & Qua Ago 8, 2001 10:54 pm & Re: [esc2k] Romulo \\
\hline 27 & 905 & GLS & Qua Ago 8, 2001 10:55 pm & Re: [esc2k] Romulo \\
\hline 28 & 907 & LMMA & Qua Ago 8, 2001 11:17 pm & curioso eu? \\
\hline 29 & 911 & LMMA & Qua Ago 8, $200111: 38 \mathrm{pm}$ & Re: [esc2k] Curiocidades \\
\hline 30 & 916 & LMMA & Qua Ago 8, 2001 11:51 pm & Re: [esc2k] Romulo \\
\hline 31 & 917 & LMMA & Qui Ago 9, $2001 \quad 12: 07 \mathrm{am}$ & Re: [esc2k] Romulo \\
\hline 32 & 922 & $\mathrm{ON}$ & Qui Ago 9, 2001 11:42 am & Re: [esc2k] Romulo \\
\hline 33 & 931 & JRP & Qui Ago 9, 2001 5:03 pm & RE: Re:[esc2k] Curiosidades 4-5-6 \\
\hline 34 & 932 & JRP & Qui Ago 9, 2001 5:06 pm & Re: [esc2k] Romulo \\
\hline 35 & 933 & JRP & Qui Ago 9, $20015: 18 \mathrm{pm}$ & Re: [esc2k] Curiocidades \\
\hline 36 & 934 & MPOA & Qui Ago 9, $20015: 23 \mathrm{pm}$ & $\begin{array}{l}\text { Re: Romulo e (Curiosidade de } \\
\text { Gaúcho) }\end{array}$ \\
\hline 37 & 940 & JRP & Qui Ago 9, 2001 6:04 pm & Curiosidades 7-8-9 \\
\hline 38 & 942 & AP & Qui Ago 9, $20016: 24 \mathrm{pm}$ & Re: [esc2k] Romulo \\
\hline 39 & 947 & MGM & Qui Ago 9, $20016: 54 \mathrm{pm}$ & Re: [esc2k] Re: Curiosidade Gaúcha \\
\hline 40 & 949 & MPOA & Qui Ago 9, 2001 7:06 pm & Re:[esc2k] Curiosidades 7-8-9 \\
\hline 41 & 950 & MGM & Qui Ago 9, 2001 7:10 pm & $\begin{array}{l}\text { Re:da lista que se torna uma } \\
\text { viagem!!!! }\end{array}$ \\
\hline 42 & 951 & ON & Qui Ago 9, 2001 7:10 pm & Re: [esc2k] Re: Curiosidade Gaúcha \\
\hline 43 & 953 & MGM & Qui Ago 9, 2001 7:26 pm & Re: [esc2k] Re: Curiosidade Gaúcha \\
\hline 44 & 957 & LAMG & Qui Ago 9, 2001 1:23 pm & Re: [esc2k] Re: Curiosidade Gaúcha \\
\hline 45 & 959 & LMMA & Qui Ago 9, 2001 9:41 pm & $\begin{array}{l}\text { Re: [esc2k] Re:da lista que se torna } \\
\text { uma viagem!!!! }\end{array}$ \\
\hline 46 & 960 & LMMA & Qui Ago 9, 2001 9:45 pm & Re: [esc2k] Romulo \\
\hline 47 & 961 & LMMA & Qui Ago 9, 2001 9:48 pm & Re: [esc2k] Curiosidades 7-8-9 \\
\hline 48 & 962 & $\mathrm{AP}$ & Qui Ago 9, 2001 9:51 pm & $\begin{array}{l}\text { Romulo, Remo, a loba... uma } \\
\text { imagem? }\end{array}$ \\
\hline 49 & 963 & $\mathrm{AP}$ & Qui Ago 9,2001 9:59 pm & Re: [esc2k] Romulo \\
\hline
\end{tabular}




\begin{tabular}{|c|c|c|c|c|}
\hline 50 & 966 & LMMA & Qui Ago 9, 2001 10:12 pm & Re: [esc2k] Romulo \\
\hline 51 & 968 & LL & Qui Ago 9, 2001 8:03 pm & churrasco \\
\hline 52 & 970 & GLS & Sex Ago 10, 2001 12:36 am & Re: [esc2k] Romulo \\
\hline 53 & 974 & JRP & Sex Ago 10,2001 5:09 pm & Curiosidades 10-11-12 \\
\hline 54 & 975 & JRP & Sex Ago 10,2001 5:19 pm & Re: [esc2k] Re: Curiosidade Gaúcha \\
\hline 55 & 977 & JRP & Sex Ago 10, $20015: 32 \mathrm{pm}$ & Re: [esc2k] Curiosidades 7-8-9 \\
\hline 56 & 978 & JRP & Sex Ago 10, 2001 5:35 pm & $\begin{array}{l}\text { Re: [esc2k] Romulo, Remo, a loba... } \\
\text { uma imagem? }\end{array}$ \\
\hline 57 & 981 & MPOA & Sex Ago 10,2001 7:40 pm & Re:[esc2k] churrasco \\
\hline 58 & 982 & MPOA & Sex Ago 10, 2001 8:04 pm & $\begin{array}{l}\text { Re:[esc2k] Romulo, Remo, a loba... } \\
\text { uma imagem? }\end{array}$ \\
\hline 59 & 983 & MPOA & Sex Ago 10, 2001 8:14 pm & Curiosidade ( Expert) \\
\hline 60 & 984 & MPOA & Sex Ago 10,2001 8:19 pm & Re:[esc2k] curioso eu? \\
\hline 61 & 985 & LL & Sex Ago 10, 2001 9:42 pm & $\begin{array}{l}\text { Re: Re:[esc2k] Romulo, Remo, a } \\
\text { loba... uma imagem? }\end{array}$ \\
\hline 62 & 993 & NM & Sáb Ago 11, 2001 10:42 am & Curiosidades \\
\hline 63 & 994 & NM & Sáb Ago 11, 2001 10:43 am & Romulo \\
\hline 64 & 995 & NM & Sáb Ago 11, 2001 10:46 am & Churrasco \\
\hline 65 & 1000 & JRP & Sáb Ago 11, 2001 3:01 pm & Re: [esc2k] Curiosidades \\
\hline 66 & 1040 & GLS & Seg Ago 13, 2001 8:27 am & Mitologia, quem gosta? \\
\hline 67 & 1044 & NM & Seg Ago 13, 2001 8:35 am & Re: [esc2k] Mitologia, quem gosta? \\
\hline 68 & 1047 & nmar & Seg Ago 13, 2001 3:26 pm & Re:[esc2k] Motologia lanomani...? \\
\hline 69 & 1051 & JRP & Seg Ago 13, $20015: 15 \mathrm{pm}$ & Curiosidades 13-14-15 \\
\hline 70 & 1063 & GLS & Seg Ago 13, 2001 10:48 pm & Re: [esc2k] Motologia lanomani...? \\
\hline 71 & 1087 & JRP & Ter Ago 14, 2001 5:31 pm & Curiosidades 16-17-18 \\
\hline 72 & 1107 & JRP & Qua Ago 15, $20015: 19 \mathrm{pm}$ & Curiosidades 19-20-21 \\
\hline 73 & 1122 & nmar & Qua Ago 15, 2001 9:14 pm & Re: [esc2k] Motologia lanomani...? \\
\hline 74 & 1129 & $\mathrm{AP}$ & Qua Ago 15, 2001 10:25 pm & Agua gelada??? \\
\hline 75 & 1132 & nmar & Qua Ago 15, 2001 10:36 pm & Re:[esc2k] Agua gelada-Dri? \\
\hline 76 & 1145 & JRP & Qui Ago 16, 2001 5:20 pm & Curiocidades $22-23-24$ \\
\hline 77 & 1146 & ON & Qui Ago 16, 2001 5:32 pm & Re: [esc2k] Curiocidades 22-23-24 \\
\hline 78 & 1164 & LMMA & Qui Ago 16, 2001 9:08 pm & Re: Re:[esc2k] Agua gelada-Dri? \\
\hline 79 & 1186 & $\mathrm{AP}$ & Qui Ago 16, 2001 10:53 pm & Re: Re:[esc2k] Agua gelada-Dri? \\
\hline 80 & 1230 & $\mathrm{CM}$ & Dom Ago 19, 2001 5:36 pm & (Sem assunto) \\
\hline 81 & 1232 & nmar & Dom Ago 19, 2001 6:40 pm & Re:[esc2k] Matemática e vida \\
\hline 82 & 1233 & nmar & Dom Ago 19, 2001 6:48 pm & Re: Re:[esc2k] Aulas de matemática \\
\hline 83 & 1235 & LMMA & Dom Ago 19, 2001 9:11 pm & Re: Re:[esc2k] Aulas de matemática \\
\hline 84 & 1236 & LMMA & Dom Ago 19, 2001 9:17 pm & Re: [esc2k] (unknown) \\
\hline 85 & 1242 & LS & Dom Ago 19, 2001 10:31 pm & Re: Re:[esc2k] Aulas de matemática \\
\hline 86 & 1255 & LM & Data: Seg Ago 20, 2001 4:23 pm & resposta atrasada... \\
\hline 87 & 1256 & JRP & Seg Ago 20,2001 5:30 pm & Curiosidades 25-26-27 \\
\hline 88 & 1273 & nmar & Seg Ago 20, $2001 \quad 10: 15 \mathrm{pm}$ & Re:[esc2k] (unknown) \\
\hline 89 & 1274 & nmar & Seg Ago 20, 2001 10:21 pm & Re: Re:[esc2k] Aulas de matemática \\
\hline 90 & 1275 & EOCC & Seg Ago 20, 2001 10:31 pm & RE: [esc2k] (unknown) \\
\hline 91 & 1276 & LMMA & Seg Ago 20, 2001 10:38 pm & Re: Re:[esc2k] Aulas de matemática \\
\hline 92 & 1277 & nmar & Seg Ago 20, 2001 10:32 pm & Re: Re:[esc2k] Aulas de matemática \\
\hline 93 & 1278 & LMMA & Seg Ago 20, $2001 \quad 10: 41 \mathrm{pm}$ & Re: [esc2k] (unknown) \\
\hline 94 & 1279 & nmar & Seg Ago 20, 2001 10:55 pm & RE: [esc2k] (unknown) \\
\hline 95 & 1280 & nmar & Seg Ago 20,2001 10:59 pm & Re: [esc2k] (unknown) \\
\hline 96 & 1283 & NM & Seg Ago 20, $2001 \quad 11: 57 \mathrm{pm}$ & Re: [esc2k] (unknown) \\
\hline 97 & 1308 & JRP & Ter Ago 21, 2001 6:09 pm & Curiosidades 28-29-30 \\
\hline 98 & 1362 & JRP & Sex Ago 24, 2001 5:19 pm & Curiosidades 31-32-33 \\
\hline 99 & 1415 & JRP & Ter Ago 28, 2001 9:24 am & Curiosidades 34-35-36 \\
\hline 100 & 1560 & JRP & Ter Set 4, $20015: 09 \mathrm{pm}$ & Curiosidades 34-35-36 \\
\hline 101 & 1563 & JRP & Ter Set 4, $20016: 10 \mathrm{pm}$ & Rômulo e Remo/parte2 \\
\hline 102 & 1589 & NM & Qua Set 5, 2001 10:30 pm & $\begin{array}{l}\text { Re: [esc2k] Rômulo e } \\
\text { Remo/parte2YXJ0ZTI= }\end{array}$ \\
\hline 103 & 1605 & JRP & Qui Set 6, 2001 5:48 pm & Re: [esc2k] Rômulo e \\
\hline
\end{tabular}




\begin{tabular}{|l|l|l|l|l|}
\hline & & & & \\
\hline 104 & 1606 & JRP & Qui Set 6, 2001 6:01 pm & Curiosidades 37-38-39 \\
\hline 105 & 1693 & JRP & Qua Set 12,2001 5:21 pm & Curiosidades 40-41-42 \\
\hline 106 & 1696 & JRP & Qua Set 12, 2001 6:15 pm & Re: [esc2k] Curiosidades 40-41-42 \\
\hline 107 & 1905 & JRP & Qui Set 27, 2001 6:00 pm & Curiosidades 49-50-51 \\
\hline 108 & 1942 & JRP & Qua Out 3, 2001 $10: 01 \mathrm{am}$ & Curiosidades 43-44-45 \\
\hline 109 & 1944 & JRP & Qua Out 3, 2001 $10: 06 \mathrm{am}$ & Curiosidades 46-47-48 \\
\hline 110 & 1945 & JRP & Qua Out 3, 2001 $10: 21 \mathrm{am}$ & Curiosidades 52-53-54 \\
\hline 111 & 1948 & ON & Qua Out 3, 2001 $11: 07 \mathrm{am}$ & judeus e muculmanos \\
\hline 112 & 1964 & JRP & Qui Out 4, 2001 3:42 pm & Re: [esc2k] judeus e muculmanos \\
\hline 113 & 2298 & T & Seg Out 29, 2001 $5: 15 \mathrm{pm}$ & Re: [esc2k] Fernando Pessoa \\
\hline 114 & 2311 & JRP & Ter Out 30,2001 7:11 pm & Re: [esc2k] Fernando Pessoa \\
\hline
\end{tabular}

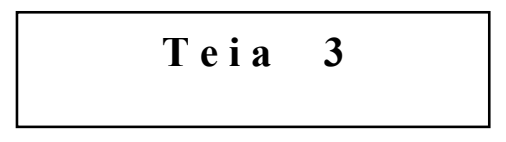

Título - Fortaleza

Essa teia é formada por 68 mensagens e 20 participantes, no período de 17 de julho a 20 de agosto

O ponto de partida dessas mensagens é feito por um integrante da equipe técnica do IAS informando e convidando os assinantes para o XXI Congresso Anual sobre tecnologia da informação e a questão social, organizado pela Sociedade Brasileira de Computação (SBC) em Fortaleza-CE, no período de 30 de julho a 3 de agosto de 2001. Essa mensagem gera várias mensagens que discutem a organização do encontro. Durante o Congresso, os participantes das escolas parceiras enviam mensagens narrativas explicando como o evento está se realizando e alguns assinantes que não foram ao evento interagem pela lista. Depois do evento surgem várias mensagens com mais narrativas e a teia termina com mensagens de avaliação do encontro. 
Diagrama da Teia 3

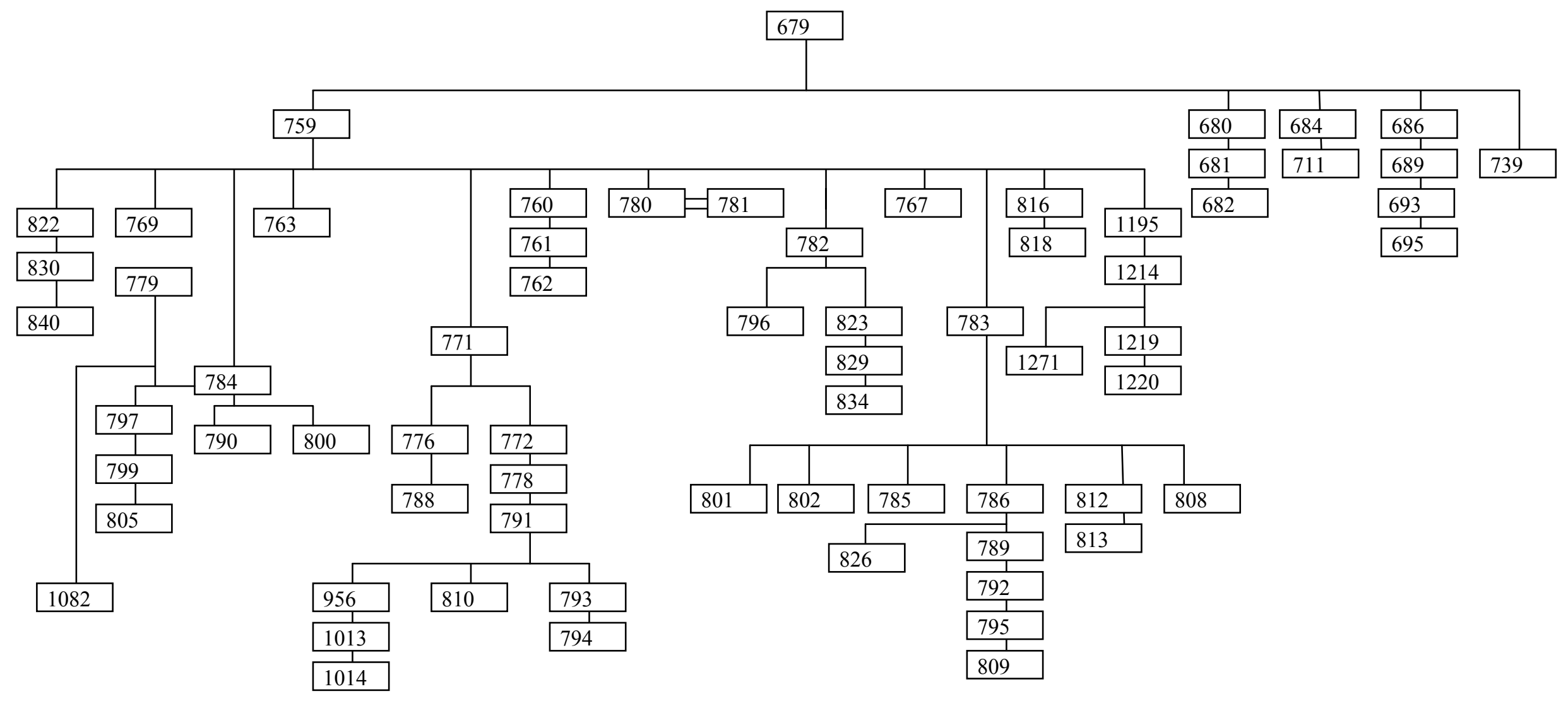


Em seguida (e na próxima página) apresento uma tabela com todas as informações do cabeçalho da teia 3 .

\begin{tabular}{|c|c|c|c|c|}
\hline & Mensagem & De & Data & Assunto \\
\hline 1 & 679 & ON & Ter Jul 17, $20016: 35 \mathrm{pm}$ & encontro em fortaleza \\
\hline 2 & 680 & GLS & Ter Jul 17, 2001 7:16 pm & Re: [esc2k] encontro em fortaleza \\
\hline 3 & 681 & GLS & Ter Jul 17, 2001 7:29 pm & Site do evento \\
\hline 4 & 682 & GLS & Ter Jul 17, 2001 7:35 pm & Re: [esc2k] encontro em fortaleza \\
\hline 5 & 684 & LMMA & Ter Jul 17, $20018: 05 \mathrm{pm}$ & Re: [esc2k] encontro em fortaleza \\
\hline 6 & 686 & job & Qua Jul 18, $20018: 37 \mathrm{am}$ & Re: [esc2k] Site do evento \\
\hline 7 & 689 & GLS & Qua Jul 18, 2001 11:01 am & Re: [esc2k] Site do evento \\
\hline 8 & 693 & job & Qua Jul 18, 2001 12:30 pm & Re: [esc2k]disculpa \\
\hline 9 & 695 & job & Qua Jul 18, $2001 \quad 12: 40 \mathrm{pm}$ & Re: [esc2k] Site do evento \\
\hline 10 & 711 & ON & Qua Jul 18, 2001 4:12 pm & Re: [esc2k] encontro em fortaleza \\
\hline 11 & 739 & VL & Ter Jul 24, 2001 12:24 pm & Re:[esc2k] encontro em fortaleza \\
\hline 12 & 759 & drip & Ter Jul 31, 2001 11:43 am & Sua Escola em Fortaleza \\
\hline 13 & 760 & RPTS & Ter Jul 31, 2001 11:12 am & Re: [esc2k] "Sua Escola" em Fortaleza \\
\hline 14 & 761 & drip & Ter Jul 31, 2001 12:36 pm & $\begin{array}{l}\text { Re:Re: [esc2k] Sua Escola em } \\
\text { Fortaleza }\end{array}$ \\
\hline 15 & 762 & RPTS & Ter Jul 31, 2001 1:17 pm & $\begin{array}{l}\text { Re: Re:Re: [esc2k] Sua Escola em } \\
\text { Fortaleza }\end{array}$ \\
\hline 16 & 763 & EA & Ter Jul 31, 2001 3:07 pm & Re: [esc2k] "Sua Escola" em Fortaleza \\
\hline 17 & 767 & LS & Qua Ago 1, 2001 9:57 am & Re: [esc2k] "Sua Escola" em Fortaleza \\
\hline 18 & 769 & cff & Qua Ago 1, 2001 6:56 pm & $\begin{array}{l}\text { XXI CONGRESSO DE } \\
\text { COMPUTAÇÃO }\end{array}$ \\
\hline 19 & 771 & drip & Qui Ago 2, 2001 12:15 pm & Boletim Fortal... \\
\hline 20 & 772 & RPTS & Qui Ago 2, 2001 3:46 pm & Re: [esc2k] Boletim Fortal... \\
\hline 21 & 776 & EA & Sex Ago 3, 2001 8:37 am & Re: [esc2k] Boletim Fortal... \\
\hline 22 & 778 & NM & Sex Ago 3, 2001 8:05 am & Re: [esc2k] Boletim Fortal... \\
\hline 23 & 779 & NM & Sex Ago 3, 2001 8:16 am & Solicitação \\
\hline 24 & 780 & MGM & Sex Ago 3, 2001 4:05 pm & Theophilo Sauer/Jussara \\
\hline 25 & 781 & MGM & Sex Ago 3, 2001 4:04 pm & (Sem assunto) \\
\hline 26 & 782 & $\mathrm{bk}$ & Sex Ago 3, 2001 4:13 pm & Fortaleza \\
\hline 27 & 783 & JMML & Sex Ago 3, 2001 6:46 pm & Encontro Fortaleza \\
\hline 28 & 784 & AP & Sex Ago 3, 2001 11:43 pm & Solicitacao \\
\hline 29 & 785 & AP & Sex Ago 3, 2001 11:50 pm & Encontro Fortaleza \\
\hline 30 & 786 & AP & Sex Ago 3, 2001 11:52 pm & Uma pergunta muito importante... \\
\hline 31 & 788 & AP & Sex Ago 3, 2001 11:59 pm & Boletim Fortal... \\
\hline 32 & 789 & NM & Sex Ago 3, 2001 9:14 pm & $\begin{array}{l}\text { Re: [esc2k] Uma pergunta muito } \\
\text { importante... }\end{array}$ \\
\hline 33 & 790 & NM & Sex Ago 3, 2001 9:15 pm & Re: [esc2k] Solicitacao \\
\hline 34 & 791 & AP & Sáb Ago 4, 2001 12:22 am & Para Rubem, Ney \& Cia... \\
\hline 35 & 792 & AP & Sáb Ago 4, 2001 12:24 am & $\begin{array}{l}\text { Re: [esc2k] Uma pergunta muito } \\
\text { importante... }\end{array}$ \\
\hline 36 & 793 & NM & Sex Ago 3, 2001 9:25 pm & Re: [esc2k] Para Rubem, Ney \& Cia... \\
\hline 37 & 794 & AP & Sáb Ago 4, 2001 12:33 am & Mascote de Sao Pedro D'Aldeia \\
\hline 38 & 795 & EOCC & Sáb Ago 4, 2001 12:50 am & $\begin{array}{l}\text { RE: [esc2k] Uma pergunta muito } \\
\text { importante... }\end{array}$ \\
\hline 39 & 796 & LS & Sáb Ago 4, 2001 9:40 am & Re: [esc2k] Fortaleza \\
\hline 40 & 797 & LS & Sáb Ago 4, 2001 9:42 am & Re: [esc2k] Solicitação \\
\hline 41 & 799 & EOCC & Sáb Ago 4, 2001 10:19 am & RE: [esc2k] Solicitacao \\
\hline 42 & 800 & RPTS & Sáb Ago 4, 2001 10:25 am & Re: [esc2k] Solicitacao \\
\hline 43 & 801 & RPTS & Sáb Ago 4, 2001 11:44 am & Re: [esc2k] Encontro Fortaleza \\
\hline 44 & 802 & ML & Sáb Ago 4, $20012: 26$ pm & Re:[esc2k] Informações \\
\hline 45 & 805 & NM & Sáb Ago 4, $20013: 28$ pm & RE: [esc2k] Solicitacao \\
\hline
\end{tabular}




\begin{tabular}{|l|l|l|l|l|}
\hline 46 & 808 & LMMA & Dom Abr 22, 2001 8:11 pm & Re: Re:[esc2k] Informações \\
\hline 47 & 809 & LMMA & Dom Abr 22, 2001 8:41 pm & $\begin{array}{l}\text { Re: [esc2k] Uma pergunta muito } \\
\text { importante... }\end{array}$ \\
\hline 48 & 810 & LMMA & Dom Abr 22, 2001 9:02 pm & De volta \\
\hline 49 & 812 & AP & Sáb Ago 4, 2001 9:55 pm & $\begin{array}{l}\text { Projetos daqui, projetos de la... Muitos } \\
\text { projetos!!! }\end{array}$ \\
\hline 50 & 813 & LMMA & Dom Abr 22, 2001 10:23 pm & $\begin{array}{l}\text { Re: [esc2k] Projetos daqui, projetos de } \\
\text { la... Muitos projetos!!! }\end{array}$ \\
\hline 51 & 816 & AP & Dom Ago 5, 2001 5:50 pm & Um pouquinho de Fortaleza \\
\hline 52 & 818 & LMMA & Seg Abr 23, 2001 9:18 pm & $\begin{array}{l}\text { Re: [esc2k] Um pouquinho de } \\
\text { Fortaleza }\end{array}$ \\
\hline 53 & 822 & F & Sáb Jan 22, 2000 12:58 am & encontro Fortaleza \\
\hline 54 & 823 & GLS & Seg Ago 6, 2001 8:21 am & Aos gauchos Claiton e Michael \\
\hline 55 & 826 & GLS & Seg Ago 6, 2001 10:08 am & $\begin{array}{l}\text { Re: [esc2k] Um pouquinho de } \\
\text { Fortaleza }\end{array}$ \\
\hline 56 & 829 & MPOA & Seg Ago 6, 2001 2:28 pm & Re: Gilberto Lacerda \\
\hline 57 & 830 & MPOA & Seg Ago 6, 2001 2:40 pm & Re:[esc2k] encontro Fortaleza \\
\hline 58 & 834 & GLS & Seg Ago 6, 2001 5:18 pm & Re: [esc2k] Re: Gilberto Lacerda \\
\hline 59 & 840 & F & Seg Ago 6, 2001 7:38 pm & Re] encontro Fortaleza \\
\hline 60 & 956 & AP & Qui Ago 9, 2001 8:18 pm & Cinara de Araxa \\
\hline 61 & 1013 & nmar & Dom Ago 12, 2001 9:02 am & Re:[esc2k] Adriana Portela \\
\hline 62 & 1014 & Nmar & Dom Ago 12, 2001 9:06 am & Re:[esc2k] Adriana Portela \\
\hline 63 & 1082 & VL & Ter Ago 14, 2001 5:08 pm & Telejornal \\
\hline 64 & 1195 & GLS & Sex Ago 17, 2001 8:31 pm & Porta voz: avaliação de Fortaleza \\
\hline 65 & 1214 & SL & Sáb Ago 18, 2001 10:12 pm & $\begin{array}{l}\text { Re: [esc2k] Porta voz: avaliação de } \\
\text { Fortaleza }\end{array}$ \\
\hline 66 & 1219 & AP & Dom Ago 19, 2001 10:37 am & Avaliando Fortaleza \\
\hline 67 & 1220 & EOCC & Dom Ago 19, 2001 11:20 am & RE: [esc2k] Avaliando Fortaleza \\
\hline 68 & 1271 & nmar & Seg Ago 20, 2001 9:40 pm & $\begin{array}{l}\text { Re: [esc2k] Porta voz: avaliação de } \\
\text { Fortaleza }\end{array}$ \\
\hline
\end{tabular}

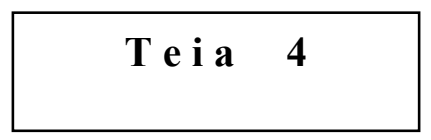

\section{Título - Projeto Crato}

Essa teia é formada por 58 mensagens e 19 participantes, no período de 8 de agosto a 28 de outubro.

O ponto de partida dessas mensagens é o pedido de sugestões de uma professora de uma escola situada na cidade do Crato, sobre uma oficina que os alunos farão para a comunidade local (um grupo de terceira idade). Essa mensagem deflagra mensagens respostas de sugestões e apoio e mensagens de alguns alunos dessa mesma escola comentando outros projetos que a escola possui. Isso gera mensagens de assinantes de vários estados comentando projetos semelhantes que estão acontecendo, oferecendo ajuda e propondo trocas virtuais. 
Diagrama da Teia 4

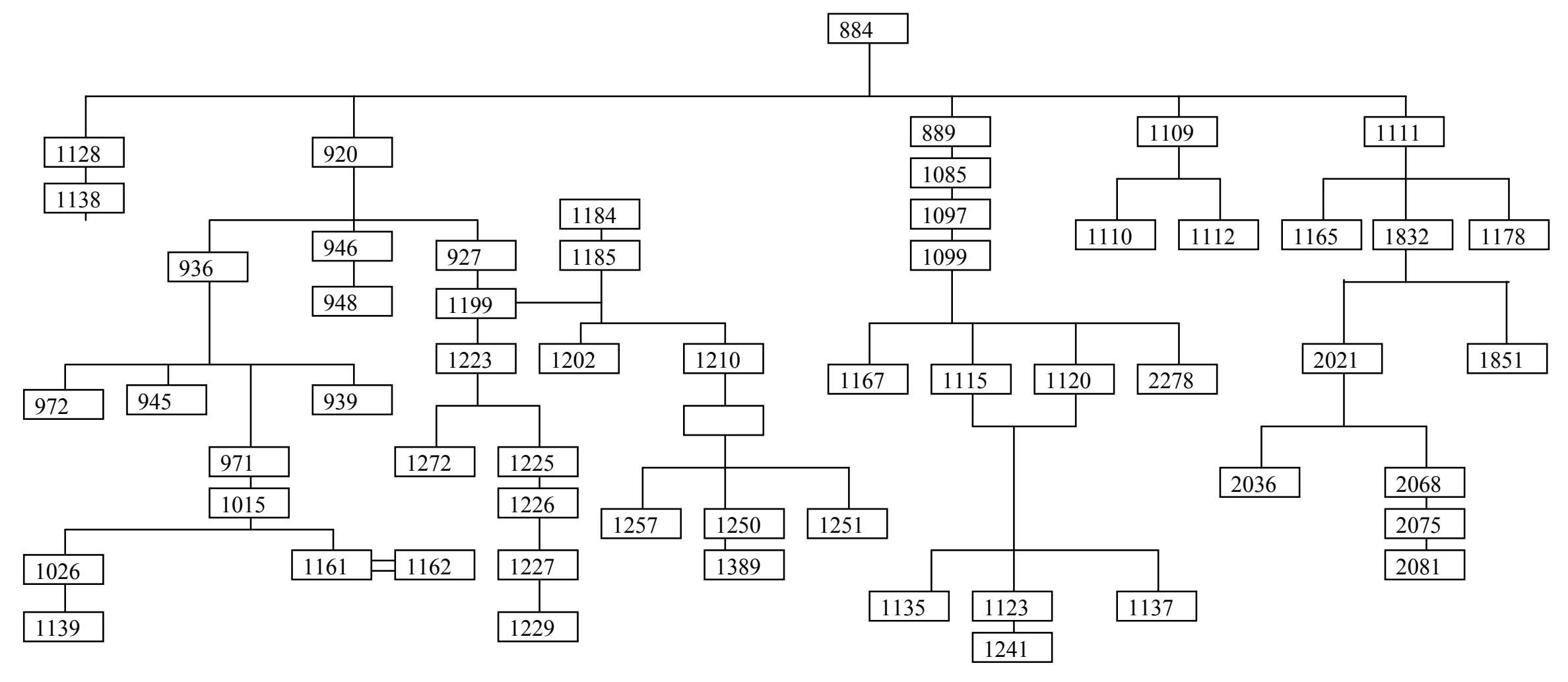


Em seguida (e na próxima página) apresento uma tabela com todas as informações do cabeçalho da teia 4.

\begin{tabular}{|c|c|c|c|c|}
\hline & Mensagem & De & Data & Assunto \\
\hline 1 & 884 & FLJ & Qua Ago 8, 2001 6:19 pm & oficina para terceira idade - dicas \\
\hline 2 & 898 & DB & Qua Ago 8, 2001 10:09 pm & $\begin{array}{l}\text { Re: [esc2k] oficina para terceira idade } \\
\text { - dicas }\end{array}$ \\
\hline 3 & 920 & gab & Qui Ago 9, 2001 9:38 am & PROJETO \\
\hline 4 & 927 & MPOA & Qui Ago 9, 2001 2:55 pm & Re:[esc2k] PROJETO \\
\hline 5 & 936 & NM & Qui Ago 9, 2001 1:34 pm & Re: [esc2k] PROJETO \\
\hline 6 & 939 & JRP & Qui Ago 9, 2001 5:56 pm & Re: [esc2k] PROJETO \\
\hline 7 & 945 & gab & Qui Ago 9, 2001 6:35 pm & Re: [esc2k] NEY MOURAO \\
\hline 8 & 946 & AP & Qui Ago 9, 2001 6:50 pm & $\begin{array}{l}\text { Ajudando o Gabriel - Tema: Jorge } \\
\text { Amado }\end{array}$ \\
\hline 9 & 948 & gab & Qui Ago 9, $20016: 55 \mathrm{pm}$ & RE: [esc2k] ADRIANA \\
\hline 10 & 971 & cff & Sex Ago 10, 2001 8:55 am & Cinara o próximo passo! \\
\hline 11 & 972 & cff & Sex Ago 10, 2001 9:00 am & Re: [esc2k]Pra Ney Mourão \\
\hline 12 & 1015 & nmar & Dom Ago 12, 2001 9:23 am & Re:[esc2k] Cesar-Fortaleza \\
\hline 13 & 1026 & NM & Dom Ago 12, 2001 8:07 am & Araxá vai aos bancos \\
\hline 14 & 1085 & FLJ & Ter Ago 14, 2001 5:24 pm & $\begin{array}{l}\text { Re: }[\operatorname{esc} 2 \mathrm{k}] \text { oficina para terceira idade } \\
\text { - dicas }\end{array}$ \\
\hline 15 & 1097 & DB & Ter Ago 14, 2001 11:37 pm & $\begin{array}{l}\text { Re: [esc } 2 k] \text { oficina para terceira idade } \\
\text { - dicas }\end{array}$ \\
\hline 16 & 1099 & DB & Qua Ago 15, 2001 9:51 am & Terceira Idade \\
\hline 17 & 1109 & $\mathrm{mg}$ & Qua Ago 15, 2001 5:28 pm & estou chegando \\
\hline 18 & 1110 & NM & Qua Ago 15, 2001 5:57 pm & Re: [esc2k] estou chegando \\
\hline 19 & 1111 & JRP & Qua Ago 15, 2001 5:57 pm & Horta medicinal \\
\hline 20 & 1112 & $\mathrm{ON}$ & Qua Ago 15, 2001 5:58 pm & Re: [esc2k] estou chegando \\
\hline 21 & 1115 & $\mathrm{gb}$ & Qua Ago 15, 2001 7:32 pm & Seja bem vinda \\
\hline 22 & 1120 & DB & Qua Ago 15, 2001 8:56 pm & Re: [esc2k] Terceira Idade \\
\hline 23 & 1123 & AP & Qua Ago 15, 2001 9:15 pm & Re: [esc2k] Terceira Idade \\
\hline 24 & 1128 & nmar & Qua Ago 15, 2001 10:00 pm & Re: [esc $2 \mathrm{k}]$ oficina para terceira idade \\
\hline 25 & 1135 & $\mathrm{~J}$ & Qui Ago 16, 2001 12:29 am & Re: [esc2k] Terceira Idade \\
\hline 26 & 1137 & NM & Qui Ago 16, 2001 10:15 am & Re: [esc2k] Terceira Idade \\
\hline 27 & 1138 & NM & Qui Ago 16, 2001 10:22 am & Re: [esc2k] oficina para terceira idade \\
\hline 28 & 1139 & NM & Qui Ago 16, 2001 10:20 am & Re:[esc2k] Intercâmbio! \\
\hline 29 & 1161 & LMMA & Dom Ago 12, 2001 10:22 pm & Matemática e vida \\
\hline 30 & 1162 & LMMA & Dom Ago 12, 2001 10:32 pm & En: Matemática e vida \\
\hline 31 & 1165 & LMMA & Qui Ago 16, 2001 9:13 pm & Re: [esc2k] Horta medicinal \\
\hline 32 & 1167 & LMMA & Qui Ago 16, 2001 9:28 pm & Re: [esc2k] Terceira Idade \\
\hline 33 & 1178 & $\mathrm{~J}$ & Qui Ago 16, 2001 2:48 pm & Re: [esc2k] Horta medicinal \\
\hline 34 & 1184 & $\mathrm{~J}$ & Sex Ago 17, 2001 12:58 am & Jane... \\
\hline 35 & 1185 & $\mathrm{~J}$ & Sex Ago 17, 2001 1:07 am & Michael... \\
\hline 36 & 1199 & $\mathrm{MM}$ & Sex Ago 17, 2001 10:20 pm & Visita a Theophilo Sauer \\
\hline 37 & 1202 & $\mathrm{mg}$ & Sáb Ago 18, 2001 9:22 am & Horta medicinal \\
\hline 38 & 1210 & JRP & Sáb Ago 18, 2001 4:33 pm & Re: [esc2k] Horta medicinal \\
\hline 39 & 1223 & $\mathrm{~J}$ & Dom Ago 19, 2001 10:16 am & $\begin{array}{l}\text { Re: [esc2k-11] Visita a Theophilo } \\
\text { Sauer }\end{array}$ \\
\hline 40 & 1224 & $\mathrm{~J}$ & Dom Ago 19, 2001 10:03 am & Horta organica \\
\hline 41 & 1225 & $\mathrm{~J}$ & Dom Ago 19, 2001 11:27 am & Theophilo Sauer... continuando \\
\hline 42 & 1226 & $\mathrm{~J}$ & Dom Ago 19, 2001 10:54 am & Colegio Theophilo Sauer \\
\hline 43 & 1227 & $\mathrm{~J}$ & Dom Ago 19, 2001 1:24 pm & Theophilo Sauer... comentando \\
\hline 44 & 1229 & MVB & Dom Ago 19, 2001 4:30 pm & Colegio Theophilo Sauer \\
\hline 45 & 1241 & GB & Sáb Ago 18, 2001 5:54 pm & Re: [esc2k] Terceira Idade \\
\hline
\end{tabular}




\begin{tabular}{|l|l|l|l|l|}
\hline 46 & 1250 & mg & Seg Ago 20, 2001 9:38 am & Horta orgânicas \\
\hline 47 & 1251 & LAMG & Seg Ago 20, 2001 10:36 am & Re: [esc2k] Horta organica \\
\hline 48 & 1257 & JRP & Seg Ago 20, 2001 5:36 pm & Re: [esc2k] Horta organica \\
\hline 49 & 1272 & nmar & Seg Ago 20, 2001 10:02 pm & $\begin{array}{l}\text { Re:[esc2k] Re: [esc2k-11] Visita a } \\
\text { Theophilo Sauer }\end{array}$ \\
\hline 50 & 1389 & J & Sáb Ago 25, 2001 11:33 am & Horta orgânicas - Gilvania \\
\hline 51 & 1832 & FJ & Dom Set 23, 2001 3:20 pm & horta organica \\
\hline 52 & 1851 & PG & Seg Set 24, 2001 4:17 pm & horta organica \\
\hline 53 & 2021 & FJ & Qua Out 10, 2001 3:36 pm & (Sem assunto) \\
\hline 54 & 2036 & PM & Qui Out 11,2001 9:59 am & Plantio \\
\hline 55 & 2068 & FJ & Seg Jan 10, 2000 1:00 am & terceira idade e horta \\
\hline 56 & 2075 & LS & Dom Out 14,2001 7:35 pm & Re: [esc2k] terceira idade e horta \\
\hline 57 & 2081 & FJ & Seg Out 15, 2001 8:33 am & Re: [esc2k] terceira idade e horta \\
\hline 58 & 2278 & J & Dom Out 28, 2001 11:47 am & Terceira Idade \\
\hline
\end{tabular}

\section{T e i a 5}

Título - Cadastro de novos membros

Essa teia é formada por 51 mensagens e 19 participantes, no período de 01 a 16 de agosto.

Essa teia se inicia com a mensagem de apresentação de uma escola da segunda edição feita por uma participante da equipe gestora do IAS. Essa mensagem gera várias mensagens de boas vindas pelos veteranos da lista, gerando mensagens de apresentação pessoal de novos assinantes dessa e de outras escolas parceiras. Há também menção às listas regionais. 


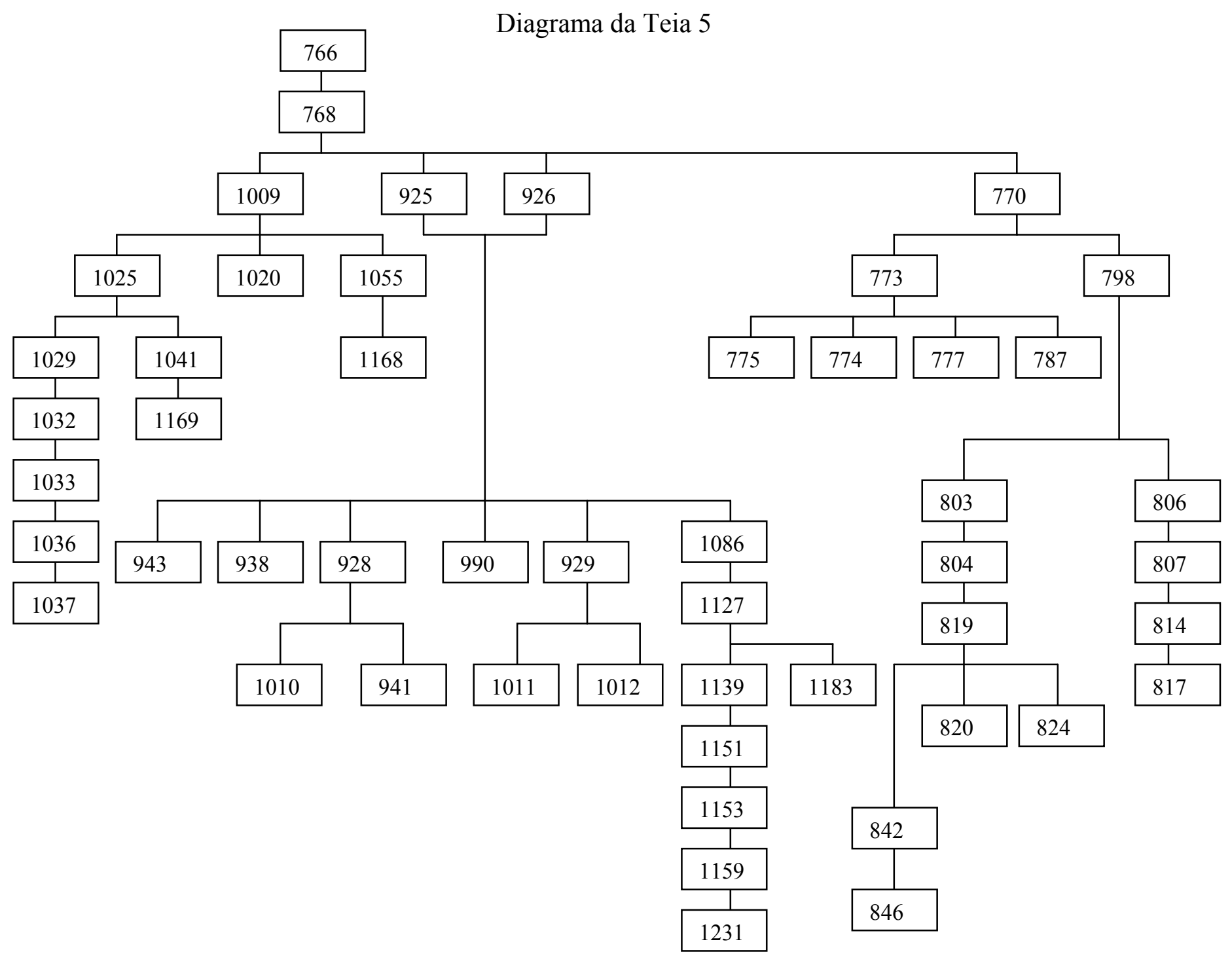




\begin{tabular}{|c|c|c|c|c|}
\hline & Mensagem & De & Data & Assunto \\
\hline 1 & 766 & L S & Qua Ago 1, 2001 9:54 am & Novos membros \\
\hline 2 & 768 & N M & Qua Ago 1, 2001 8:49 am & Re: [esc2k] Novos membros \\
\hline 3 & 770 & L S & Qui Ago 2, 2001 8:22 am & Re: [esc2k] Novos membros \\
\hline 4 & 773 & N M C & Qui Ago 2, 2001 8:42 pm & Re: [esc2k] Novos membros \\
\hline 5 & 774 & Dri & Qui Ago 2, 2001 9:20 pm & Re: [esc2k] Oi Niva \\
\hline 6 & 775 & E A & Sex Ago 3, 2001 8:26 am & Re: [esc2k] Novos membros \\
\hline 7 & 777 & $\mathrm{~N} \mathrm{M}$ & Sex Ago 3, 2001 7:15 am & Re: [esc2k] Novos membros \\
\hline 8 & 787 & A P & Sex Ago 3, 2001 11:57 pm & Re: [esc2k] Novos membros \\
\hline 9 & 798 & L S & Sáb Ago 4, 2001 9:53 am & Mais gente nova... \\
\hline 10 & 803 & L L & Sáb Ago 4, 2001 3:06 pm & Agracimento \\
\hline 11 & 804 & N M & Sáb Ago 4, 2001 3:26 pm & Escola Maria Dulce \\
\hline 12 & 806 & L L & Sáb Ago 4, 2001 5:49 pm & Fw: [esc2k] Mais gente nova... \\
\hline 13 & 807 & L M M A & Dom Abr 22, $20018: 04 \mathrm{pm}$ & Re: [esc2k] Mais gente nova... \\
\hline 14 & 814 & L L & Dom Ago 5, 2001 12:03 am & Com certeza!!!! \\
\hline 15 & 817 & L S & Dom Ago 5, 2001 9:10 pm & Re: [esc2k] Com certeza!!!! \\
\hline 16 & 819 & $\mathrm{mr}$ & Dom Ago 5, 2001 11:54 pm & (Sem assunto) \\
\hline 17 & 820 & L S & Seg Ago 6, 2001 12:20 am & Re: [esc2k] (unknown) \\
\hline 18 & 824 & $\mathrm{~N} \mathrm{M}$ & Seg Ago 6, 2001 6:35 am & Re: [esc2k] (unknown) \\
\hline 19 & 842 & D T & Seg Ago 6, 2001 10:08 pm & Confirmacao de cadastro \\
\hline 20 & 846 & L S & Seg Ago 6, 2001 11:43 pm & Re: [esc2k] Confirmacao de cadastro \\
\hline 21 & 925 & nmar & Qui Ago 9, 2001 2:33 pm & Re:[esc2k] Datas mensagens \\
\hline 22 & 926 & nmar & Qui Ago 9, 2001 2:33 pm & Re:Apresentação - Araxá \\
\hline 23 & 928 & cff & Qui Ago 9, 2001 3:16 pm & BOAS VINDAS CINARA- MG \\
\hline 24 & 929 & M POA & Qui Ago 9, 2001 4:42 pm & Re:[esc2k] BOAS VINDAS CINARA- MG \\
\hline 25 & 938 & $\mathrm{~N} \mathrm{M}$ & Qui Ago 9, 2001 1:50 pm & Re: [esc2k] Re:Apresentação - Araxá \\
\hline 26 & 941 & nmar & Qui Ago 9, 2001 6:10 pm & Re:[esc2k] BOAS VINDAS CINARA- MG \\
\hline 27 & 943 & J R P & Qui Ago 9, 2001 6:31 pm & Re:[esc2k] BOAS VINDAS CINARA- MG \\
\hline 28 & 990 & Dri & Sex Ago 10, 2001 11:27 pm & Oi Cinara \\
\hline 29 & 1009 & S L & Dom Ago 12, 2001 8:19 am & Gente nova no grupo \\
\hline 30 & 1010 & nmar & Dom Ago 12, 2001 8:38 am & Re:[esc2k] Obrigada Cesar! \\
\hline 31 & 1011 & nmar & Dom Ago 12, 2001 8:42 am & Re:[esc2k] BOAS VINDAS CINARA- MG \\
\hline 32 & 1012 & nmar & Dom Ago 12, 2001 8:43 am & Re:[esc2k] Valeu Michael \\
\hline 33 & 1020 & nmar & Dom Ago 12, 2001 10:21 am & Re:[esc2k] Oi Sueli! \\
\hline 34 & 1025 & $\mathrm{~N} \mathrm{M}$ & Dom Ago 12, 2001 8:00 am & Re: [esc2k] Gente nova no grupo \\
\hline 35 & 1029 & $\mathrm{~L} \mathrm{~L}$ & Dom Ago 12, 2001 3:06 pm & Re: [esc2k] Gente nova no grupo \\
\hline 36 & 1032 & $\mathrm{~N} \mathrm{M}$ & Dom Ago 12, 2001 5:26 pm & Para Luiz \\
\hline 37 & 1033 & $\mathrm{~N} \mathrm{M}$ & Dom Ago 12, 2001 5:28 pm & Para Luiz \\
\hline 38 & 1036 & $\mathrm{~L} \mathrm{~L}$ & Dom Ago 12, 2001 11:54 pm & Re: [esc2k] Para Luiz \\
\hline 39 & 1037 & $\mathrm{~L} \mathrm{~L}$ & Dom Ago 12, 2001 11:59 pm & Re: [esc2k] Para Sueli \\
\hline 40 & 1041 & L S & Seg Ago 13, 2001 8:42 am & Re: [esc2k] Gente nova no grupo \\
\hline 41 & 1055 & J R P & Seg Ago 13, 2001 6:16 pm & Re: [esc2k] Gente nova no grupo \\
\hline 42 & 1086 & V L & Ter Ago 14, 2001 5:27 pm & Re:[esc2k] BOAS VINDAS CINARA- MG \\
\hline 43 & 1127 & nmar & Qua Ago 15, 2001 9:53 pm & Re:[esc2k] Intercâmbio! \\
\hline 44 & 1139 & $\mathrm{~N} \mathrm{M}$ & Qui Ago 16, 2001 10:20 am & Re:[esc2k] Intercâmbio! \\
\hline 45 & 1151 & M POA & Qui Ago 16, 2001 6:55 pm & Re:[esc2k] Intercâmbio! help RS \\
\hline 46 & 1153 & nmar & Qui Ago 16, $20017: 19 \mathrm{pm}$ & Re:[esc2k] Intercâmbio! help RS \\
\hline 47 & 1159 & M POA & Qui Ago 16, 2001 8:11 pm & Re:[esc2k] Intercâmbio! help RS \\
\hline 48 & 1168 & S L & Qui Ago 16, 2001 8:46 pm & Re: [esc2k] Gente nova no grupo \\
\hline 49 & 1169 & S L & Qui Ago 16, 2001 8:59 pm & Re: [esc2k] Gente nova no grupo \\
\hline 50 & 1183 & $\mathrm{~J}$ & Sex Ago 17, 2001 1:13 am & Intercâmbio! help RS \\
\hline 51 & 1231 & nmar & Dom Ago 19, 2001 6:26 pm & Re:[esc2k] Intercâmbio! help RS \\
\hline
\end{tabular}




\begin{tabular}{|c|} 
T e i a 6 \\
Título - Estamos famosos
\end{tabular}

Essa teia é formada por 31 mensagens e 16 participantes, no período - de 28/8 a 26/09.

Nessas mensagens os assinantes conversam sobre uma reportagem da Rede Globo realizada em uma das escolas que participam do projeto do IAS. O acontecimento gera uma brincadeira sobre a conseqüente fama dos professores, o que acaba até por levantar considerações sobre a efemeridade de toda a fama. Também é referida uma reportagem sobre o projeto do IAS publicada pela Revista Isto é. Isso também gera uma brincadeira, baseada em trocadilhos com o nome da revista. Em seguida, é assunto o I Encontro entre escolas parceiras do Ceará (descrição da cidade; descrição e avaliação do encontro, com comentários sobre os assuntos discutidos).

Diagrama da Teia 6

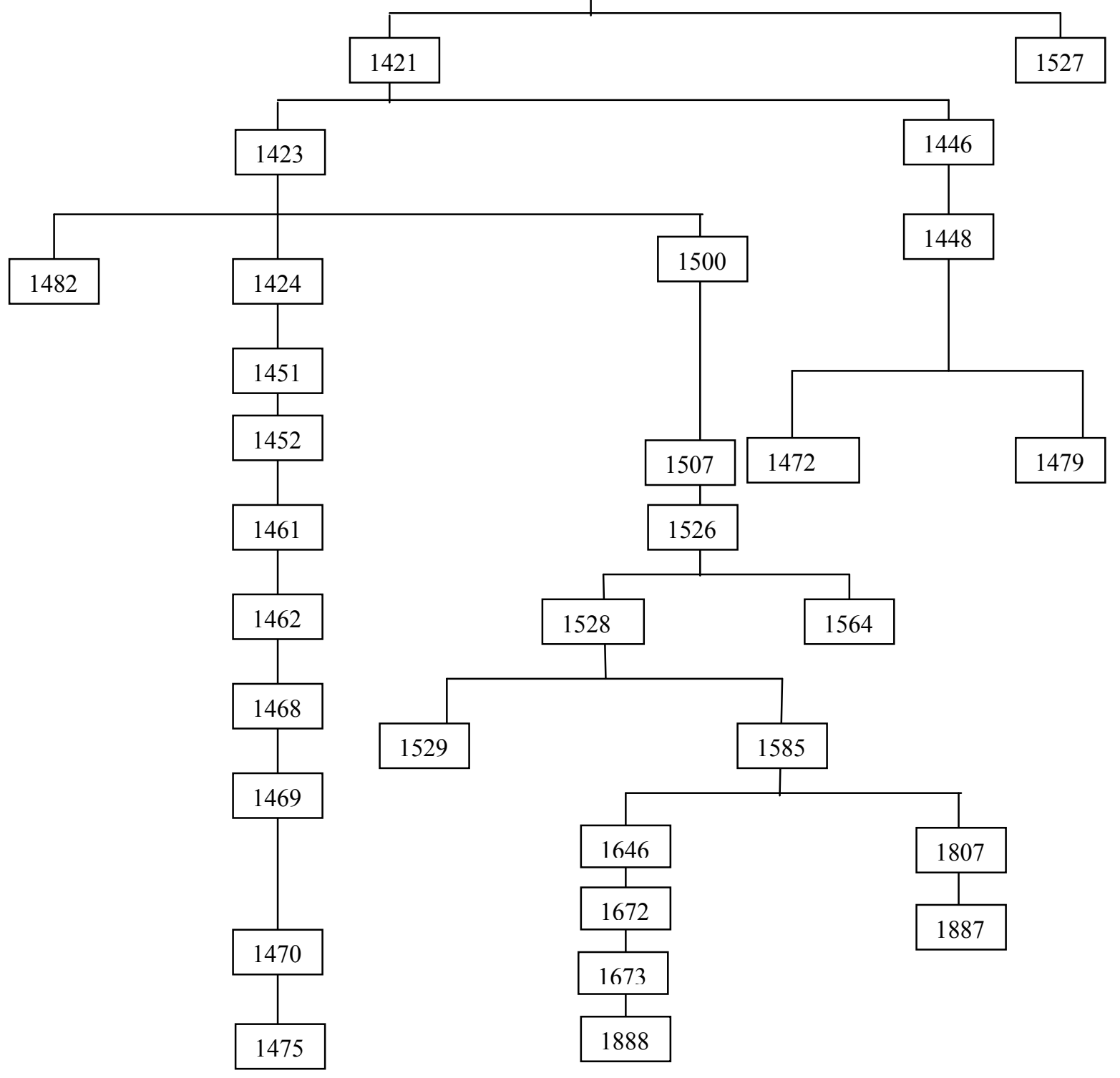


Tabela da teia 6 com as informações do cabeçalho:

\begin{tabular}{|c|c|c|c|c|}
\hline & Mensagem & De & Data & Assunto \\
\hline 1 & 1420 & J R P & Ter Ago 28, 2001 5:54 pm & ESTAMOS FAMOSOS!!!!!!! \\
\hline 2 & 1421 & $\mathrm{E} \mathrm{O} \mathrm{C} \mathrm{C}$ & Ter Ago 28, 2001 6:16 pm & RE: [esc2k] ESTAMOS FAMOSOS!!!!!!! \\
\hline 3 & 1527 & L.L & Dom Set 2, 2001 4:04 pm & Fw: Anônimos \\
\hline 4 & 1423 & A P & Ter Ago 28, 2001 8:08 pm & Revista \\
\hline 5 & 1482 & $\mathrm{jb}$ & Qui Ago 30, 2001 4:09 pm & Re: [esc2k] Revista Isto é pag 44 \\
\hline 6 & 1424 & A P & Ter Ago 28, 2001 8:13 pm & Tres "E"... na Isto "E" \\
\hline 7 & 1500 & L M M A & Qui Ago 30, 2001 10:06 pm & Encontro Meruoca \\
\hline 8 & 1446 & J R P & Qua Ago 29, 2001 2:49 pm & RE: [esc2k] ESTAMOS FAMOSOS!!!!!!! \\
\hline 9 & 1448 & A M & Qua Ago 29, 2001 2:53 pm & Re: [esc2k] ESTAMOS FAMOSOS!!!!!!!! \\
\hline 10 & 1472 & J R P & Qui Ago 30, 2001 10:54 am & Re: [esc2k] ESTAMOS FAMOSOS!!!!!!! \\
\hline 11 & 1479 & $1 \mathrm{c}$ & Qui Ago 30, 2001 2:24 pm & Re: [esc2k] ESTAMOS FAMOSOS!!!!!!!! \\
\hline 12 & 1451 & nmar & Qua Ago 29, 2001 3:50 pm & Re:[esc2k] Tres "E"... na Isto "E" \\
\hline 13 & 1452 & A P & Qua Ago 29, 2001 4:14 pm & Re: Re:[esc2k] Tres "E"... na Isto "E" \\
\hline 14 & 1461 & $\mathrm{~N} \mathrm{M}$ & Qua Ago 29, 2001 7:44 pm & Re: [esc2k] Tres "E"... na Isto "E" \\
\hline 15 & 1462 & A P & Qua Ago 29, 2001 8:00 pm & Re: [esc2k] Tres "E"... na Isto "E" \\
\hline 16 & 1468 & $\mathrm{ds} \mathrm{f}$ & Qui Ago 30, 2001 8:50 am & Re: [esc2k]Eu não estou entendendo \\
\hline 17 & 1469 & E O C C & Qui Ago 30, 2001 8:57 am & RE: [esc2k] Eu nao estou entendendo \\
\hline 18 & 1470 & $\mathrm{ds} \mathrm{f}$ & Qui Ago 30, 2001 8:56 am & RE: [esc2k] Eu nao estou entendendo \\
\hline 19 & 1475 & $\mathrm{~N} \mathrm{M}$ & Qui Ago 30, 2001 11:24 am & RE: [esc2k] Eu nao estou entendendo \\
\hline 20 & 1507 & $\mathrm{cff}$ & Sex Ago 31, 2001 9:27 am & Re: [esc2k] Encontro Meruoca \\
\hline 21 & 1526 & $\mathrm{c} \mathrm{m}$ & Dom Set 2, 2001 9:59 am & Meruoca \\
\hline 22 & 1528 & $1 \mathrm{mo}$ & Dom Set 2, 2001 5:48 pm & Meruoca 2 \\
\hline 23 & 1564 & J R P & Ter Set 4, $20016: 18 \mathrm{pm}$ & Re: [esc2k] Meruoca \\
\hline 24 & 1529 & drip & Dom Set 2, $20015: 55 \mathrm{pm}$ & Re:[esc2k] Meruoca 2 \\
\hline 25 & 1585 & $1 \mathrm{mo}$ & Qua Set 5, $20018: 43 \mathrm{pm}$ & meruoca 3 \\
\hline 26 & 1646 & J R P & Seg Set 10, $20016: 43 \mathrm{pm}$ & Re: [esc2k] meruoca 3 \\
\hline 27 & 1672 & L MC M A & Ter Set 11, $20016: 51 \mathrm{pm}$ & Re: [esc2k] Meruoca 3 \\
\hline 28 & 1673 & J R P & Ter Set 11, 2001 7:12 pm & Meruoca 4 \\
\hline 29 & 1888 & J R P & Qua Set 26, $20015: 28 \mathrm{pm}$ & Meruoca 5 \\
\hline 30 & 1807 & A M & Qui Set 20, 2001 11:08 am & Re: [esc2k] meruoca 3 \\
\hline 31 & 1887 & J R P & Qua Set 26, $20014: 35 \mathrm{pm}$ & Re: [esc2k] meruoca 3 \\
\hline
\end{tabular}




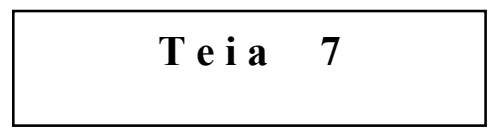

Título - Depredação

Essa teia é formada por 19 mensagens e 10 participantes, no período de 7 a 14 de agosto.

Nessas mensagens, os assinantes conversam sobre o problema da depredação das escolas (carteiras, banheiros, etc.), procurando meios para resolver ou amenizar o problema, ou até mesmo evitá-lo. Experiências (bem-sucedidas) são relatadas, sugestões são fornecidas. O envolvimento da comunidade para resolução dessa questão (e de outras) é particularmente lembrado, de modo que, ao final, a discussão sobre a relação escola/comunidade passa a ser o centro da teia.

Diagrama da Teia 7

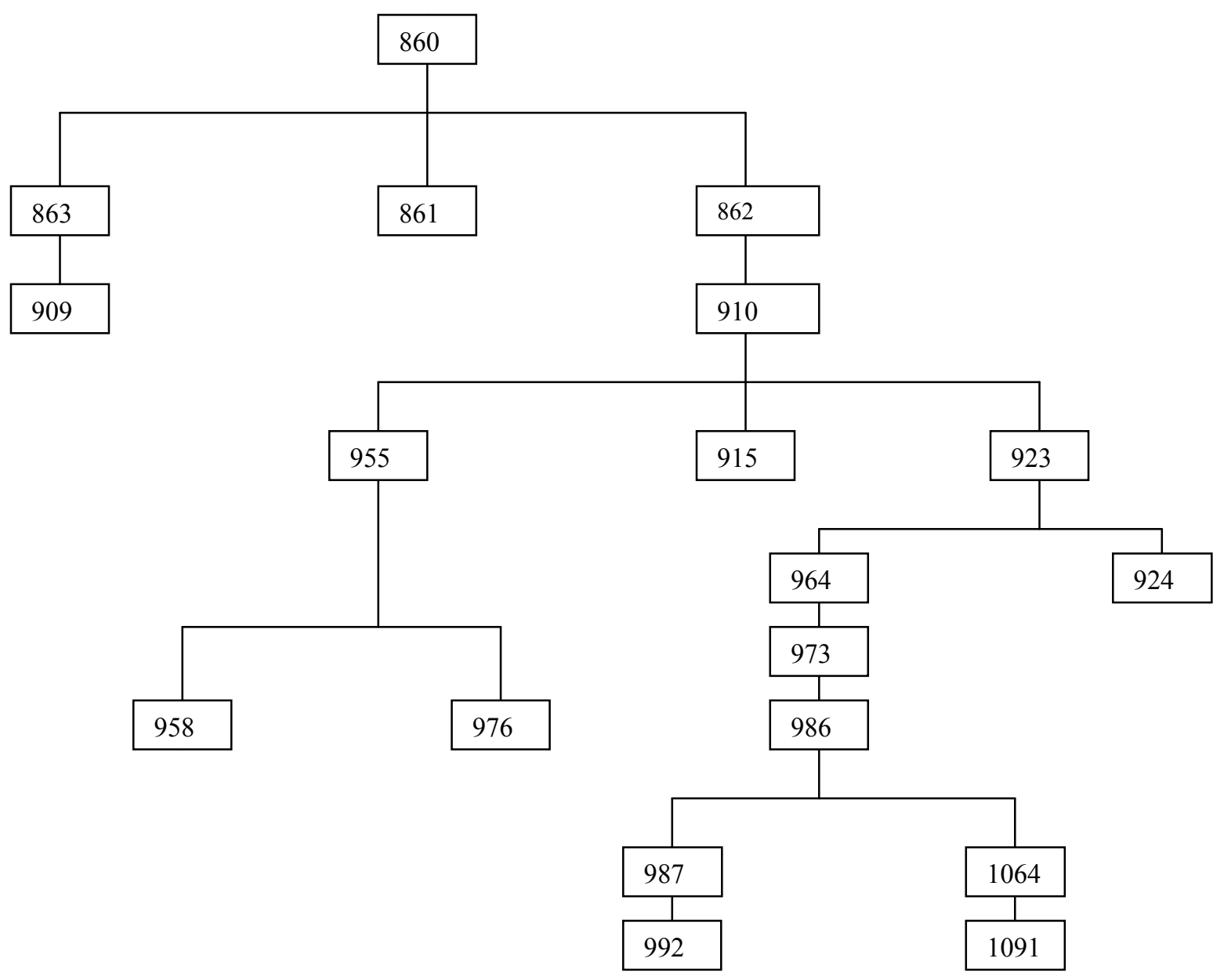


Tabela da teia 7 com as informações do cabeçalho:

\begin{tabular}{|l|l|l|l|l|}
\hline & Mensagem & De & Data & Assunto \\
\hline 1 & 860 & J R P & Ter Ago 7, 2001 6:10 pm & Depredação de cadeiras \\
\hline 2 & 863 & N M & Ter Ago 7, 2001 5:11 pm & $\begin{array}{l}\text { Re: [esc2k] Depredação de } \\
\text { cadeirasRlaXJhcw== }\end{array}$ \\
\hline 3 & 861 & M L & Ter Ago 7, 2001 6:34 pm & Re:[esc2k] Depredação de cadeiras \\
\hline 4 & 862 & A P & Ter Ago 7, 2001 8:14 pm & Re: [esc2k] Depredacao de cadeiras \\
\hline 5 & 909 & L M M A & Qua Ago 8, 2001 $11: 24 \mathrm{pm}$ & Depredação \\
\hline 6 & 910 & L M M A & Qua Ago 8, 2001 $11: 31 \mathrm{pm}$ & Re: [esc2k] Depredacao de cadeiras \\
\hline 7 & 955 & A P & Qui Ago 9, 2001 $7: 41 \mathrm{pm}$ & Re: [esc2k] Depredacao \\
\hline 8 & 915 & E O C C & Qua Ago 8, 2001 $11: 45 \mathrm{pm}$ & RE: [esc2k] Depredacao \\
\hline 9 & 923 & O N & Qui Ago 9, 2001 $11: 53 \mathrm{am}$ & Re: [esc2k] Depredação \\
\hline 10 & 958 & L M M A & Qui Ago 9, 2001 $9: 20 \mathrm{pm}$ & Re: [esc2k] Depredacao \\
\hline 11 & 976 & J R P & Sex Ago 10, 2001 5:26 pm & Re: [esc2k] Depredacao \\
\hline 12 & 964 & L M M A & Qui Ago 9, 2001 9:59 pm & Re: [esc2k] Depredação \\
\hline 13 & 924 & O N & Qui Ago 9, 2001 $12: 33$ pm & Marilac \\
\hline 14 & 973 & O N & Sex Ago 10, 2001 $10: 47$ am & Participação da Comunidade \\
\hline 15 & 986 & L M M A & Sex Ago 10, 2001 $10: 49 \mathrm{pm}$ & Re: [esc2k] Participação da Comunidade \\
\hline 16 & 987 & G L S & Sex Ago 10, 2001 $10: 45$ pm & Re: [esc2k] Participação da Comunidade \\
\hline 17 & 992 & L L & Sáb Ago 11, 2001 $11: 35$ am & Re: [esc2k] Participção da Comunidade \\
\hline 18 & 1064 & C A N & Ter Ago 14, 2001 $10: 26$ am & Re: [esc2k] Participação_da_Comunidade \\
\hline 19 & 1091 & A P & Ter Ago 14, 2001 8:02 pm & Participacao da Comunidade \\
\hline
\end{tabular}




\section{T e i a 8}

\section{Título - Fórum Matias Barbosa}

Essa teia é formada por 19 mensagens e 6 participantes, no período de 13 de julho a 19 de agosto.

Nessas mensagens, os assinantes conversam sobre um fórum organizado pela escola E.E.Evaristo G. Simas- Matias Barbosa-MG, cujo objetivo foi o de discutir como é ou deve ser a escola pública ideal. Os assinantes elogiam a iniciativa e, após o sucesso do encontro, entusiasmados, descrevem-no, comentando os seus frutos. E. C., a partir da referência ao insight com que iniciou sua palestra no Fórum, comenta a importância do sonho e dos projetos para as realizações na vida. Finalmente, os assinantes conversam também sobre a organização do próximo encontro: a festa do folclore.

Diagrama da Teia 8

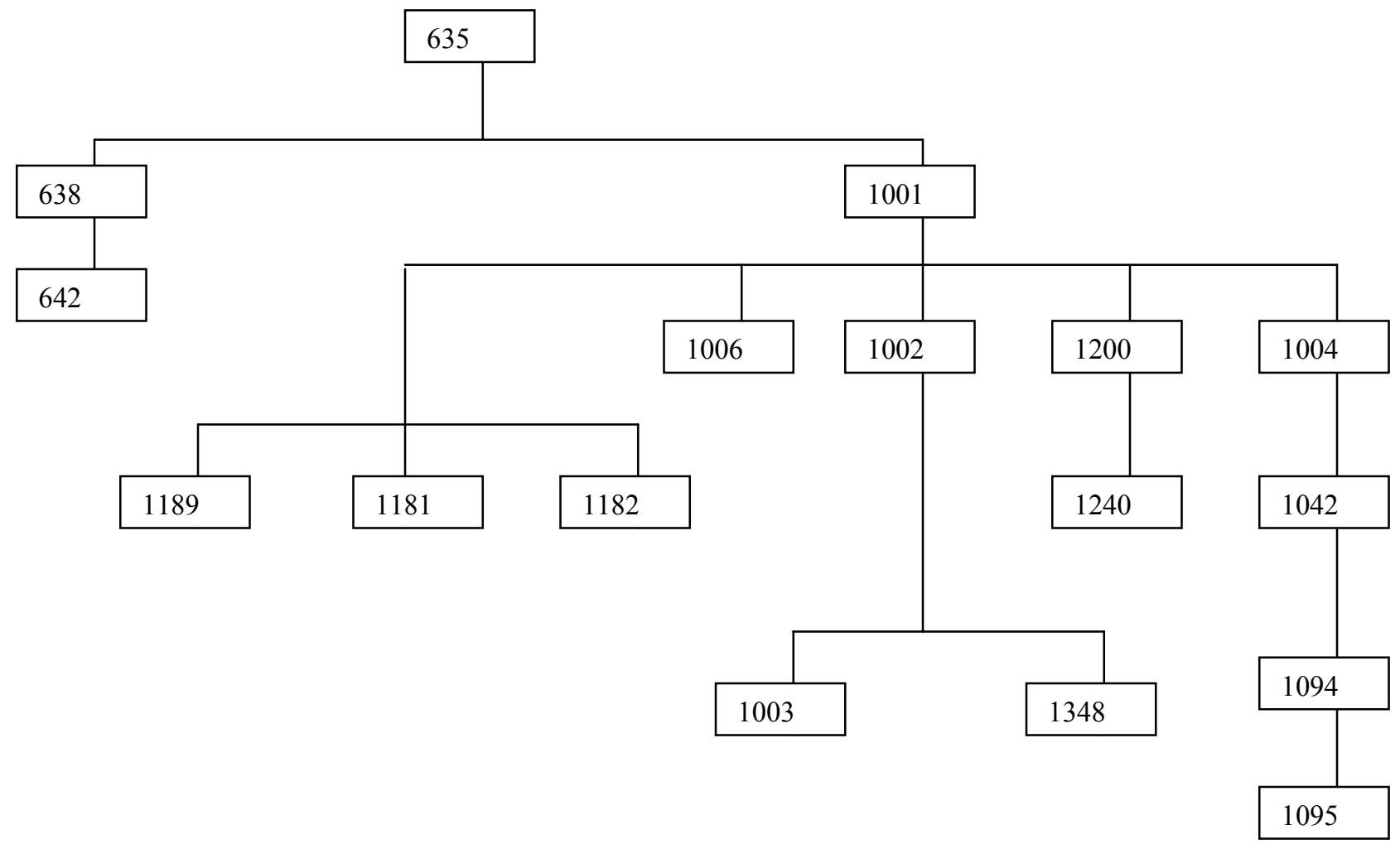


Tabela da teia 8 com as informações do cabeçalho:

\begin{tabular}{|l|l|l|l|l|}
\hline & Mensagem & De & Data & Assunto \\
\hline 1 & 635 & L S & Sex Jul 13, 2001 11:42 am & Convite para o forum \\
\hline 2 & 638 & N M & Sex Jul 13, 2001 9:25 am & Re: [esc2k] Convite para o forum \\
\hline 3 & 642 & C V & Sex Jul 13, 2001 6:34 pm & Re: [esc2k] Convite para o forum \\
\hline 4 & 1001 & L S & Sáb Ago 11, 2001 4:22 pm & Forum Matias Barbosa \\
\hline 5 & 1004 & D & Sáb Ago 11, 2001 5:52 pm & Entrando no grupo \\
\hline 6 & 1006 & N M & Sáb Ago 11, 2001 7:49 pm & Re: [esc2k] Forum Matias Barbosa \\
\hline 7 & 1176 & A P & Qui Ago 16, 2001 10:50 pm & VIAGEM A MATIAS BARBOSA \\
\hline 8 & 1200 & D & Sex Ago 17, 2001 10:51 pm & Notícias de Matias \\
\hline 9 & 1240 & L S & Dom Ago 19,2001 10:24 pm & Re: [esc2k] Noticias de Matias \\
\hline 10 & 1042 & L S & Seg Ago 13, 2001 8:52 am & Re: [esc2k] Entrando no grupo \\
\hline 11 & 1094 & D & Ter Ago 14, 2001 9:55 pm & Re: [esc2k] Entrando no grupo \\
\hline 12 & 1095 & L S & Ter Ago 14, 2001 10:11 pm & Re: [esc2k] Entrando no grupo \\
\hline 13 & 1189 & N M & Sex Ago 17, 2001 10:48 am & Re: [esc2k] VIAGEM A MATIAS BARBOSA \\
\hline 14 & 1181 & L S & Qui Ago 16, 2001 11:41 pm & Re: [esc2k] VIAGEM A MATIAS BARBOSA \\
\hline 15 & 1182 & E O C C & Qui Ago 16, 2001 11:49 pm & RE: [esc2k] VIAGEM A MATIAS BARBOSA \\
\hline 16 & 1002 & E O C C & Sáb Ago 11, 2001 5:15 pm & RE: [esc2k] Forum Matias Barbosa \\
\hline 17 & 1003 & A P & Sáb Ago 11,2001 5:48 pm & Re: [esc2k] Forum Matias Barbosa \\
\hline 18 & 1348 & E O C C & Qui Ago 16, 2001 11:05 pm & $\begin{array}{l}\text { Sonhos e Projetos de Vida: O tesouro a } \\
\text { descobrir pela educacao }\end{array}$ \\
\hline
\end{tabular}

\section{T e i a 9}

\section{Título - Academia Brasileira de Letras}

Essa teia é formada por 17 mensagens, 9 participantes, no período de 13 a 21 de agosto.

O ponto de partida dessas mensagens é uma reportagem do Fantástico sobre a sucessão de cadeira na Academia Brasileira de Letras, após o falecimento de Jorge Amado. São feitos comentários sobre o significado, papel e estrutura da academia, bem como sobre os candidatos (Paulo Coelho, Jô Soares e Zélia Gattai). Também são dadas opiniões de voto. Outro assunto é a integração da terceira idade aos projetos do IAS. 


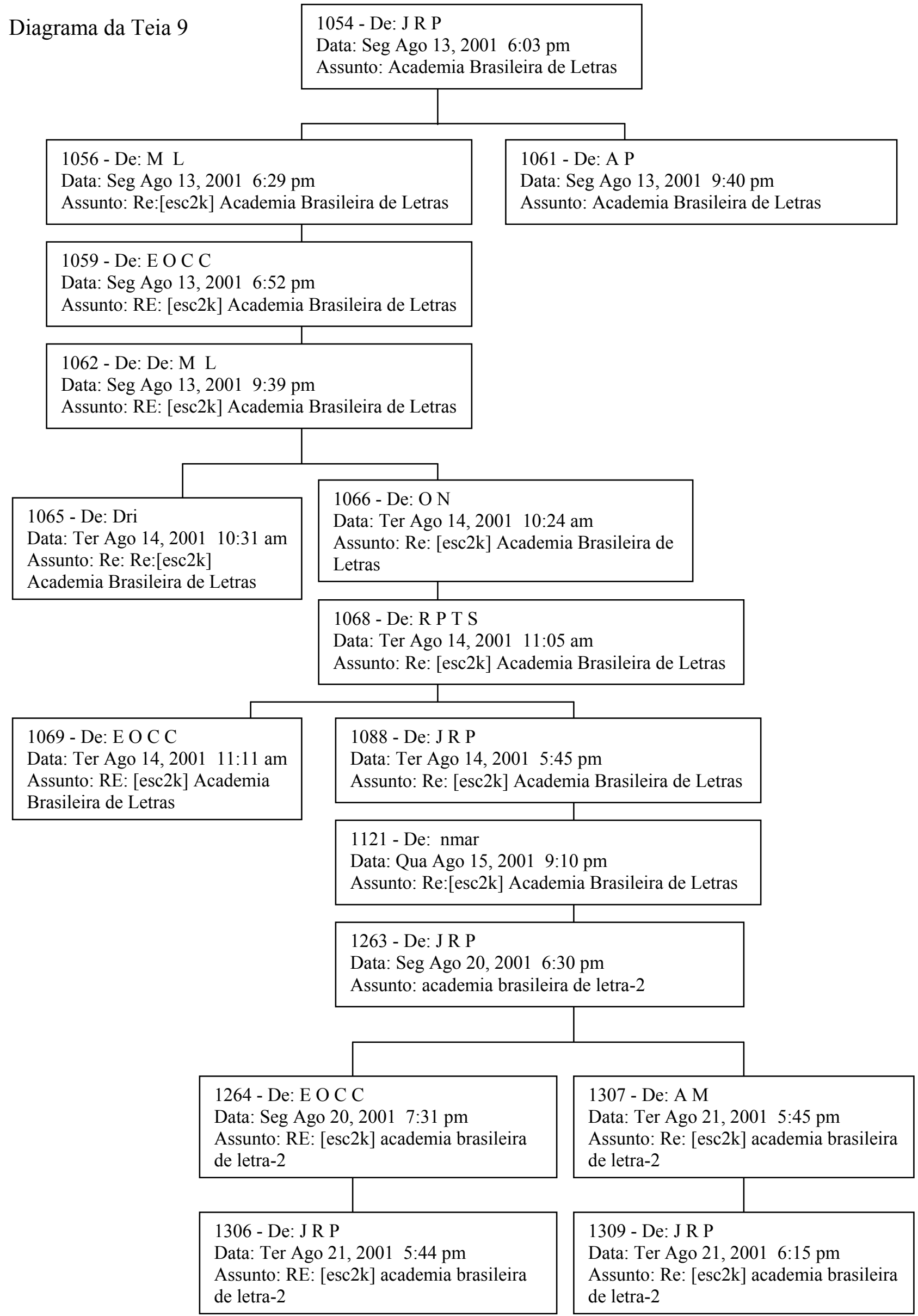




\section{Te i a 10}

Título - Encontro das escolas do DF; Bate papo e $1^{\mathrm{a}}$ imersão em SP

Essa teia é formada por 17 mensagens, 5 participantes, no período de 13 de julho a 18 de agosto.

Nessas mensagens, os assinantes marcam um encontro virtual no chat da "Escola 2000". Marcam também o Encontro das Escolas do Distrito Federal. Os e-mails trazem resoluções sobre a organização e estrutura do evento (por exemplo, quem serão os participantes?). Além disso, trazem comentários sobre o processo da própria organização em si (por exemplo, não deveria contar ela com a participação ativa dos alunos?). A preparação do Encontro também traz à tona da conversa a primeira semana de imersão em São Paulo. Finalmente, um encontro realizado entre professores da escola normal de Taguatinga, escola de Ceilândia e Núcleo Bandeirante é lembrado e descrito. 


\section{Diagrama da Teia 10}

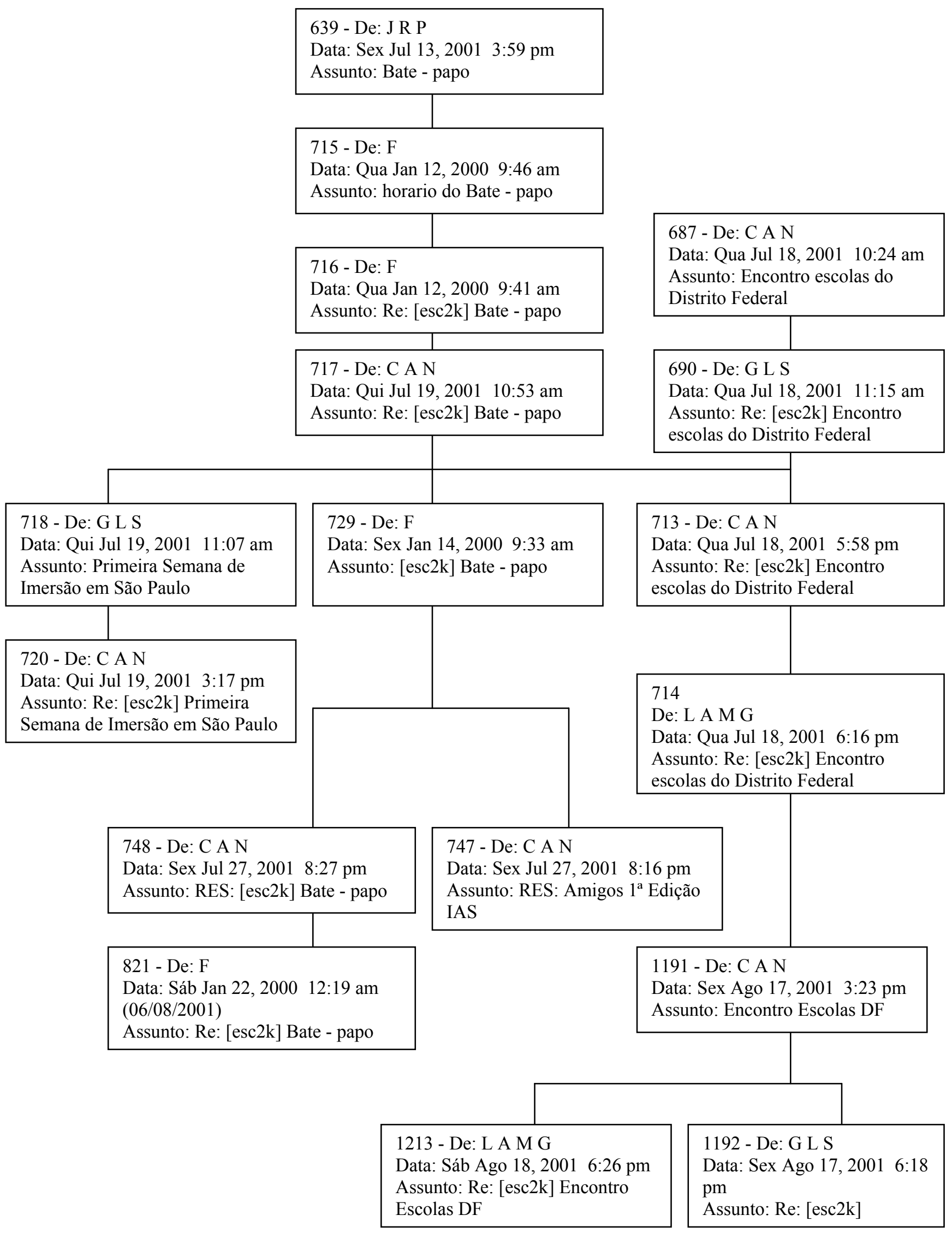




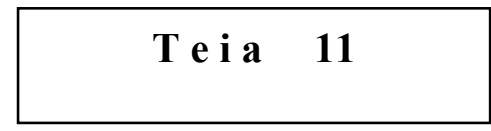

Título - Lago azul e Colégio Pe Morelli

Essa teia é formada por 16 mensagens e 8 participantes, no período de 21 de agosto a 19 de setembro.

Nessas mensagens, os assinantes conversam sobre o projeto "O lago azul pede socorro", trazido à conversa por uma aluna do Colégio Padre Cláudio Morelli, onde o trabalho se desenvolve. A aluna é muito bem recebida pelos professores que a estimulam a falar de seus sonhos e lutar por eles. Um projeto semelhante também é descrito (CEDOA).

Diagrama da Teia 11

1321 - De: eu

Data: Ter Ago 21, 2001 10:34 pm

Assunto: "Lago Azul"

1324 - De: N M

Data: Ter Ago 21,

2001 11:14 pm

Assunto: Re:

[esc2k] "Lago Azul"

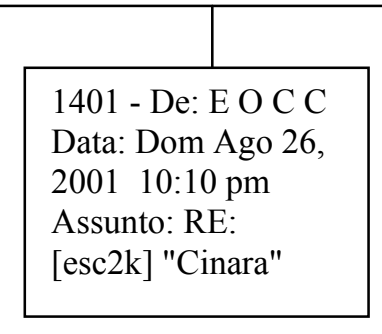

1328 - De: RM P T

Data: Qua Ago 22, 2001

9:33 am

Assunto: Re: [esc2k] "Lago

Azul"
1338 - De: eu

Data: Qua Ago 22, 2001 10:49 pm Assunto: "Agradecimento à N M"

1346 - De: nmar

Data: Qui Ago 23, 2001 2:07 pm

Assunto: Re: [esc2k] Orientador -

Rubem

1412 - De: RM P T

Data: Ter Ago 28, 2001 8:54 am

Assunto: Re: [esc2k] Orientador -

Rubem

1348 - De: nmar

Data: Qua Ago 29, 2001 3:18 pm

Assunto: Re: [esc2k] Orientador -

Rubem

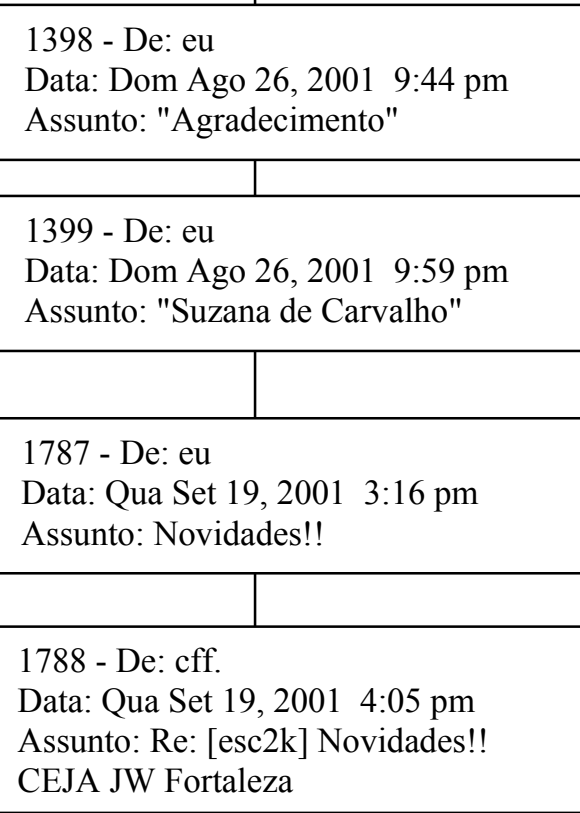

1332 - De: S L 1349

Data: Qua Ago 22, 2001 7:59 pm

Assunto: Re:

[esc2k] "Lago

Azul"
Data: Qui Ago 23, $20012: 53 \mathrm{pm}$

Assunto: Lago Azul

e Rio Ururaí
1345 - De: nmar

Data: Qui Ago

23, 2001 2:03

pm

Assunto:

Re:[esc2k]

"Lago Azul"
1400 - De: eu

Data: Dom Ago 26, 2001

10:04 pm

Assunto: "Cinara" 


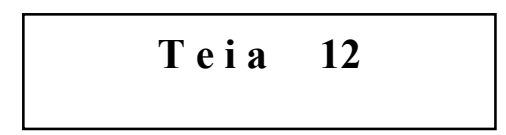

Título: - Frases especiais para pessoas especiais

Essa teia é formada por 15 mensagens e 9 participantes, no período de 29 de agosto a 12 de setembro.

O ponto de partida para essas mensagens é um texto enviado por Josué, um dos assinantes: "frases especiais para serem ditas a pessoas especiais". Os assinantes comentam as frases e a atitude de Josué: o que o motiva? Além disso, comentam positivamente a prática do envio dessas mensagens bonitas e especulam sobre rumos diferentes e destinos outros que elas acabam tomando (mural da escola, diários, etc.). Finalmente, refletem sobre a importância do apontamento da fonte e do autor das mensagens. Procedimento que é, então, seguido por outra assinante, que envia um poema. A valorização da autoria dos alunos é, por fim, lembrada. 
Diagrama da Teia 12

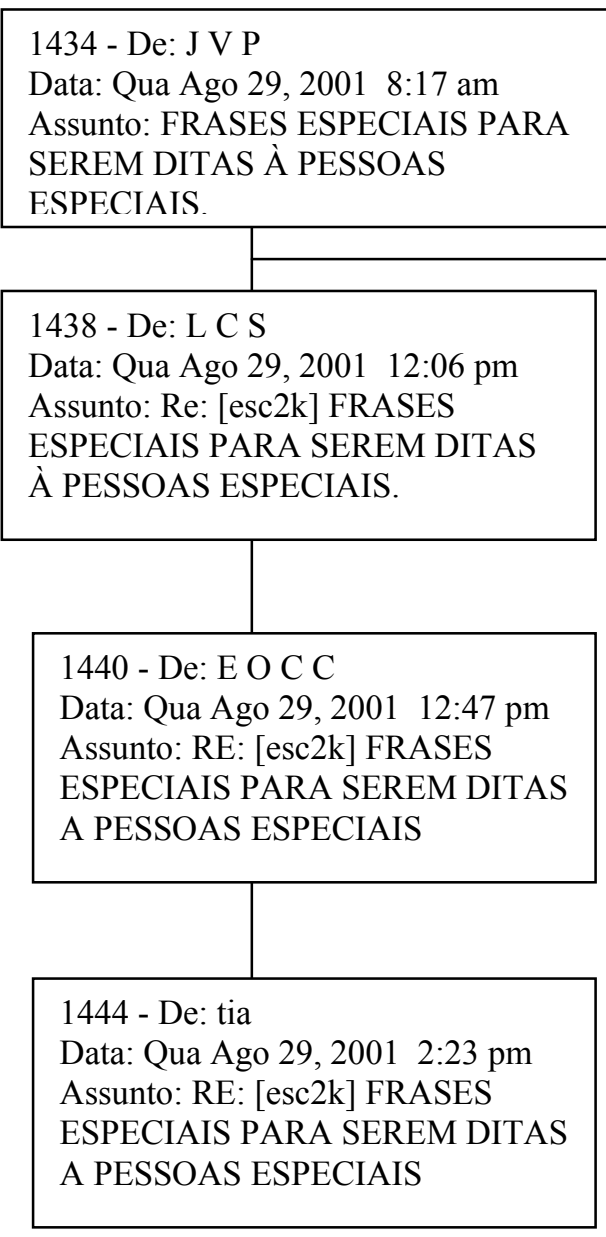

1435 - De: J V P

Data: Qua Ago 29, 2001 8:18 am Assunto: CITAÇÕES
1513 - De: J V P

Data: Sex Ago 31, 2001 8:04 pm Assunto: FRASES ESPECIAIS

PARA SEREM DITAS À PESSOAS ESPECIAIS.
1441 - De: L M

Data: Qua Ago 29, 2001 1:12 pm

Assunto: frases especiais ou citações

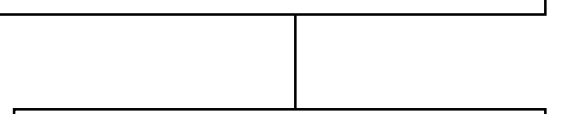

1483 - De: nmar

Data: Qui Ago 30, 2001 4:22 pm Assunto: Re:[esc2k] frases especiais ou citações

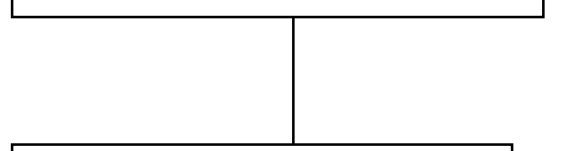

1534

De: L M

Data: Seg Set 3, 2001 1:00 pm Assunto: Re: Re:[esc2k] frases especiais ou citações
1533 - De: L M

Data: Seg Set 3, 2001 1:02 pm Assunto: FRASES ESPECIAIS PARA SEREM DITAS À PESSOAS ESPECIAIS.

\begin{tabular}{|l|}
\hline 1571 - De: E A \\
Data: Qua Set 5, 2001 8:11 am \\
Assunto: Re: [esc2k] FRASES \\
ESPECIAIS PARA SEREM \\
DITAS À PESSOAS \\
ESPECIAIS \\
\hline
\end{tabular}

1550 - De: F

Data: Seg Set 3, 2001 8:43 pm Assunto: Re: Re:[esc2k] frases especiais ou citações

1554 - De: d s f

Data: Ter Set 4, 2001 7:44 am

Assunto:

$\mathrm{Re}:[R e:[e s c 2 k]$ frases_especiais ou citacões

1555 - De: L M

Data: Ter Set 4, 2001 7:59 am

Assunto:

Re:_Re:[esc2k]_frases_especiais_ou _citações
1684

De: L M

Data: Qua Set 12, 2001 1:26 pm

Assunto: autoria 


\section{T e i a 13}

\section{Título- Lista discussão EE Bahia}

de agosto.

Essa teia é formada por 14 mensagens e 8 participantes, no período de 14 de julho a 30

O ponto de partida dessas mensagens é a criação, por um aluno, de uma lista de discussão para a Escola Estado da Bahia, com o objetivo de tornar possível a solução de dúvidas sobre o projeto do IAS. A iniciativa, embora haja dúvidas sobre o objetivo e funcionamento da lista, é muito bem recebida, gerando interesses sobre o projeto da escola.

\section{Diagrama da Teia 13}

644 - De: J V P

Data: Sáb Jul 14, 2001 10:35 am

Assunto: Re: [esc2k]Novidade
1498 - De: J V P

Data: Qui Ago 30, 2001 8:11 pm

Assunto: Nossa Lista
645 - De: J V P

Data: Sáb Jul 14, 2001 10:37 am

Assunto: Re: [esc2k]Novidade
850 - De: D A J

Data: Ter Ago 7, 2001 11:29 am

Assunto: Re: 「esc2k $\rceil$ Novidades

\begin{tabular}{l|l|} 
& \\
\cline { 2 - 2 } & \\
\hline & \\
\hline
\end{tabular}

646

De: N M

Data: Sáb Jul 14, 2001 8:03 am Assunto: Re: [esc2k]Novidade
837 - De: G L S

Data: Seg Ago 6, 2001 6:25

pm

Assunto: Re: [esc2k]

Novidades
836 - De: mpoa

Data: Seg Ago 6, 2001 6:14 pm

Assunto: Re:[esc2k] Josue
839 - De: G L S

Data: Sáb Jul 14, 2001 1:09 pm

Assunto: Bem-vindo ao grupo ebahia

6:02 pm

Assunto: Novidades
Data: Seg Ago 6, 2001 6:44 pm

Assunto: Re: [esc2k]

Novidades

\section{5 - De: L M M A}

Data: Seg Ago 6, 2001

11:14 pm

Assunto: Re: [esc2k]

Novidades

849 - De: G L S

Data: Ter Ago 7, 2001

11:07 am

Assunto: Re: [esc2k]

Novidades
847 - De: E A

Data: Ter Ago 7, 2001 10:20 am

Assunto: Re: $\lceil$ esc2k $\rceil$ Novidades 


\section{T e i a 14}

Título - Amor da Denise

Essa teia é formada por 11 mensagens e 3 participantes, no período de 29 de agosto a 3 de setembro.

O ponto de partida dessas mensagens é uma pergunta de uma das assinantes sobre a época de abertura do aeroporto de Araxá. Ela esclarece que seu interesse pelo assunto nasce do fato de que o amor de sua vida reside na cidade. Outros assinantes pedem, então, que ela relate essa história de amor. É o que acontece.

\section{Diagrama da Teia 14}

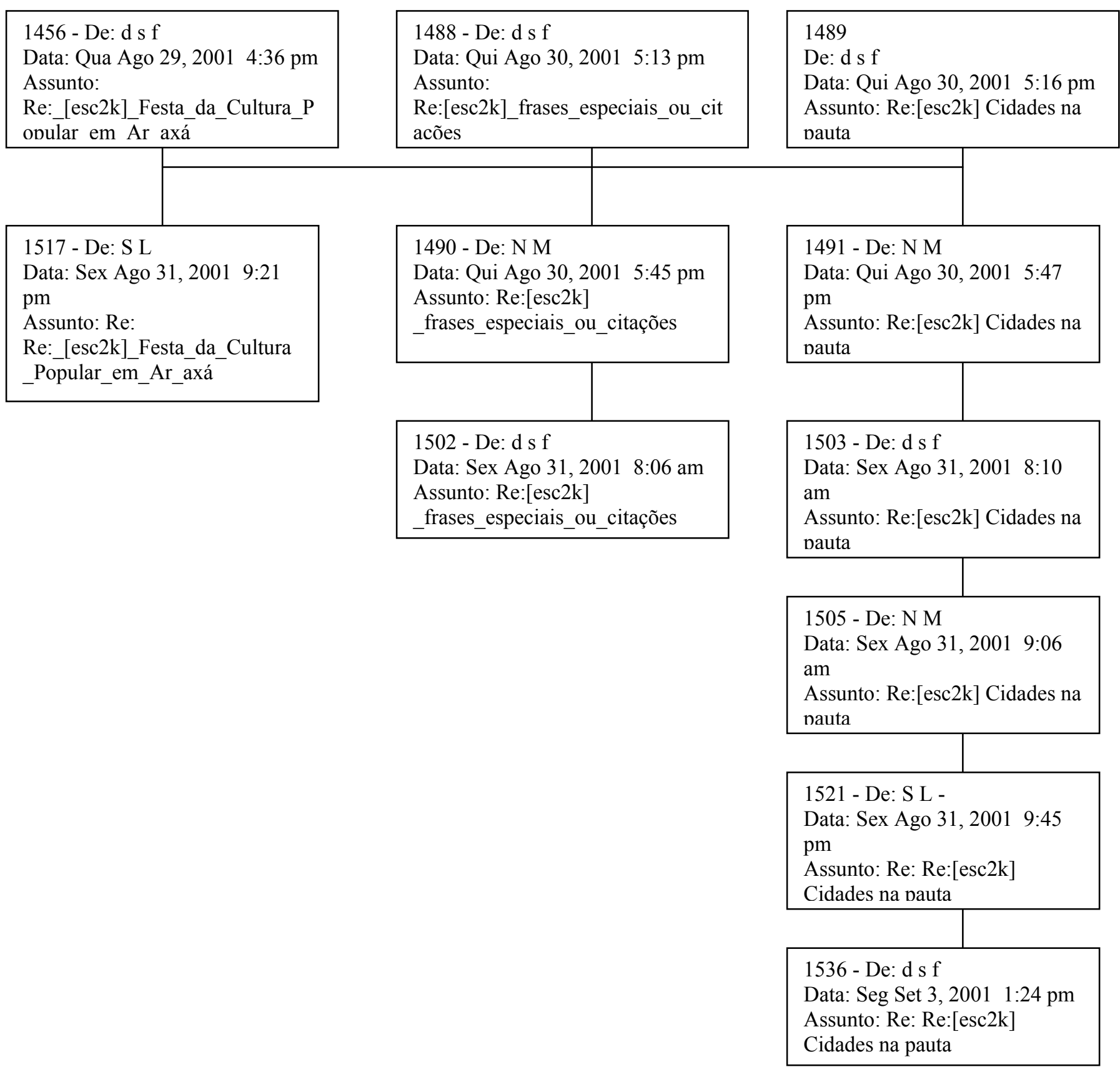




\section{T e i a 16}

\section{Título - Data mensagens do Crato}

Essa teia é formada por 11 mensagens e 6 participantes, no períodode 6 a 8 de agosto.

Nessas mensagens, trata-se do problema de que as mensagens de determinados assinantes estão chegando a E. C. com datas erradas. São ensinados os procedimentos para evitar o problema, que, no entanto, persiste, mostrando-se generalizado.

\section{Diagrama da Teia 16}

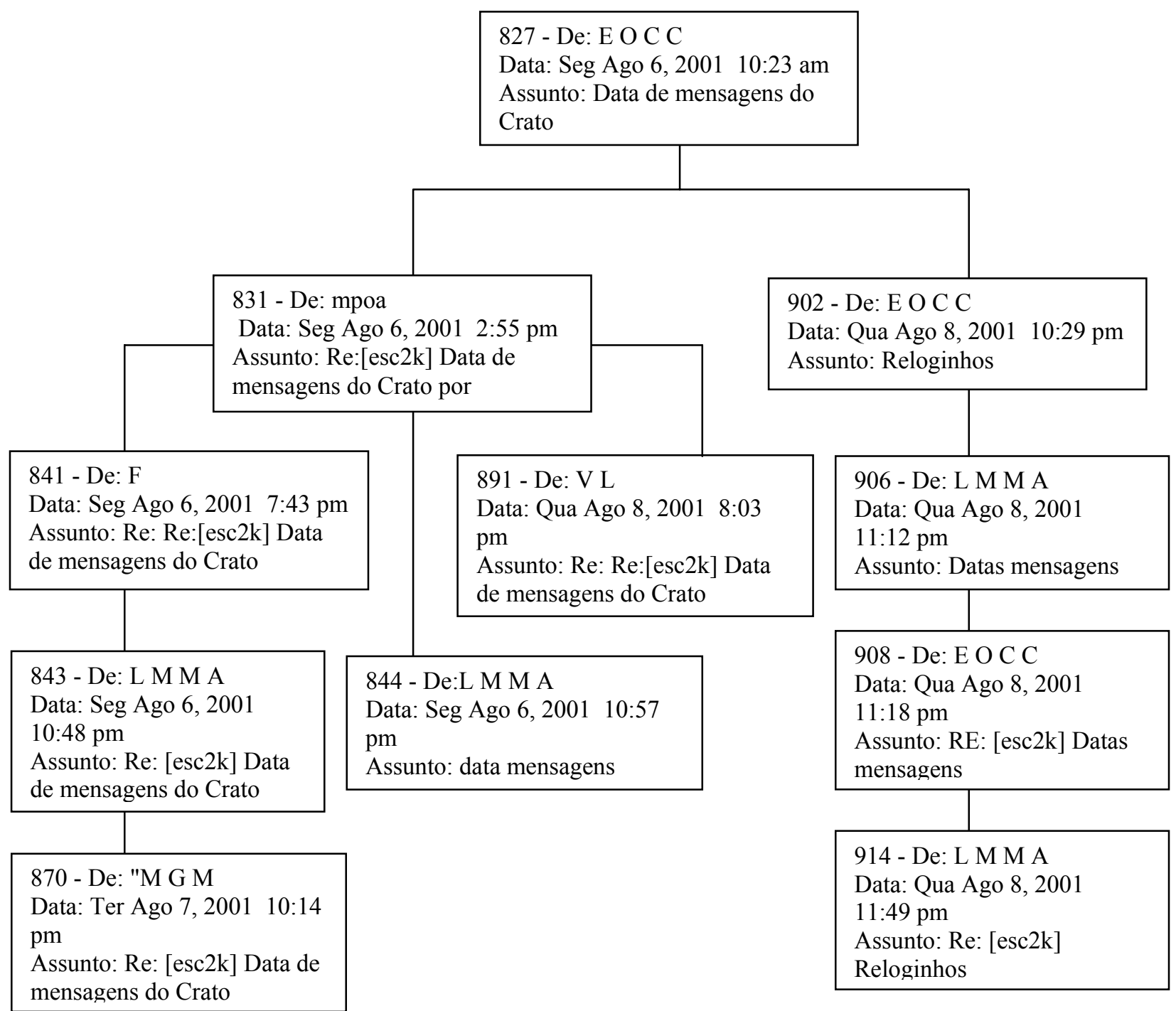




\section{T e i a 17}

Título - Palestra: Educação a distância - E. C

Essa teia é formada por 10 mensagens e 3 participantes, no período de 13 a 21 de agosto.

O ponto de partida destas mensagens é o ciclo de palestras a respeito de educação à distância e tecnologia, organizado pela Unicamp. O evento foi transmitido pela internet, sem necessidade de inscrição para acessá-la. Surgiram algumas críticas quanto a qualidade da transmissão, muitas dúvidas técnicas de como visualizá-la no computador e houve a percepção de como o uso de recursos tecnológicos pode diminuir a distância entre as pessoas e facilitar o acesso à informação. 
1052 - De: E O C C

Data: Seg Ago 13, 2001 5:51 pm

Assunto: FW: [edutec] Palestra:

"Educacao a Distancia e Tecnologia" c/

Prof. Eduardo Chaves

1102 - De: E O C C

Data: Qua Ago 15, 2001 10:35 am

Assunto: Slides da palestra de hoje

1288 - De: E O C C

Data: Ter Ago 21, 2001 9:39 am

Assunto: EN: Video da palestra do

Eduardo Chaves

1293 - De: E O C C

Data: Ter Ago 21, 2001 10:35 am

Assunto: RE: [esc2k] EN: Video da

palestra do Eduardo Chaves

1318 - De: L S

Data: Ter Ago 21, 2001 9:19 pm

Assunto: Re: [esc2k] EN: Video da palestra do Eduardo Chaves

1319 - De: N M

Data: Ter Ago 21, 2001 9:50 pm

Assunto: Re: [esc2k] EN: Video da palestra do Eduardo Chaves

1320 - De: L S

Data: Ter Ago 21, 2001 10:14 pm Assunto: Re: [esc2k] EN: Video da palestra do Eduardo Chaves

1322 - De: E O C C

Data: Ter Ago 21, 2001 10:25 pm

Assunto: RE: [esc2k] EN: Video da palestra do Eduardo Chaves

1325 - De: N M

Data: Ter Ago 21, 2001 11:16 pm Assunto: RE: [esc2k] EN: Video da palestra do Eduardo Chaves

1326 - De: E O C C

Data: Ter Ago 21, 2001 11:26 pm

Assunto: RE: [esc2k] EN: Video da palestra do Eduardo Chaves 


\section{T e i a 18}

Título - Reinaugaração do Hotel do Barreiro

Essa teia é formada por 10 mensagens e 4 participantes, no período de 15 a 22 de agosto.

O ponto de partida destas mensagens é a reinauguração das obras do Grande Hotel do Barreiro, em Araxá. A partir deste acontecimento, os participantes do fórum retomam a história da lugar no contexto local, regional e nacional. A pessoa que inicia a conversa questiona os demais se ela poderia ser uma boa guia turística da cidade. O evento contou com a participação de artistas de grande reconhecimento e de políticos. Os moradores acreditam que, quando estiver pronto, o hotel dará forte impulso à atividade turística da cidade. 
Diagrama da Teia 18

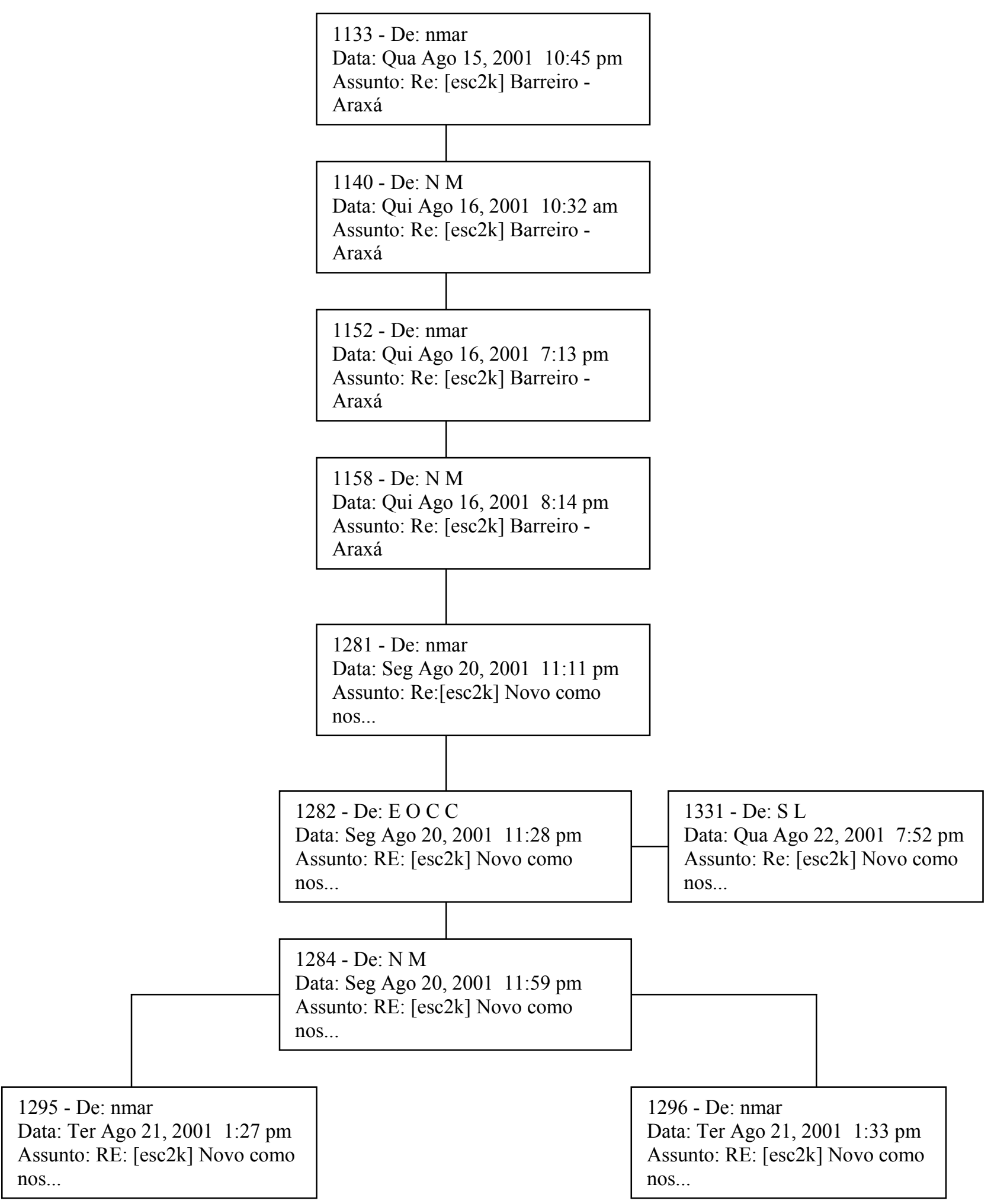




\section{T e i a 19}

Título - Festa da Cultura Popular em Araxá

Essa teia é formada por 10 mensagens e 5 participantes, no período de 26 a 31 de agosto.

O ponto de partida destas mensagens é o Festival Regional de Cultura Popular em Araxá. A participante do fórum que inicia a conversa compartilha com os demais a atuação de sua escola no festival. A escola ganhou no festival um livro que trata do orgulho de ser mineiro, e os demais participantes do fórum debatem trechos desse livro, perguntam detalhes das apresentações ocorridas no festival e sobre o samba-enredo de uma escola carioca que falava sobre Araxá e que foi apresentada neste evento. A partir daí retomam outros sambasenredo que homenagearam cidades brasileiras. 


\section{Diagrama da Teia 19}

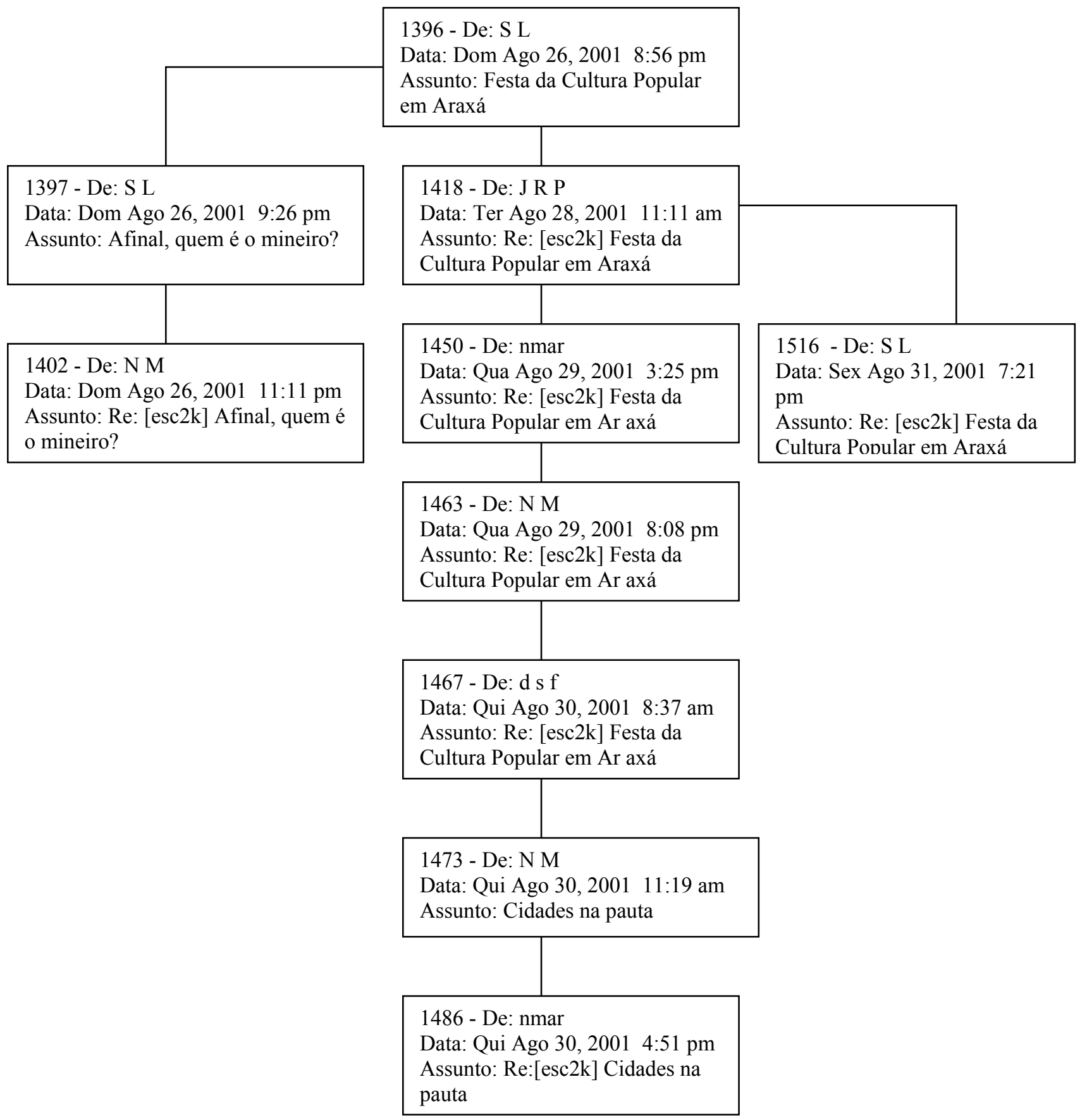




\section{T e i a 20}

\section{Título - Site Paideia Filosofico}

Essa teia é formada por 10 mensagens e 2 participantes, no período de 8 a 24 de agosto e fala sobre a inauguração de um site sobre Filosofia da Educação, gerando discussões acerca de Filosofia.

\section{Diagrama da Teia 20}

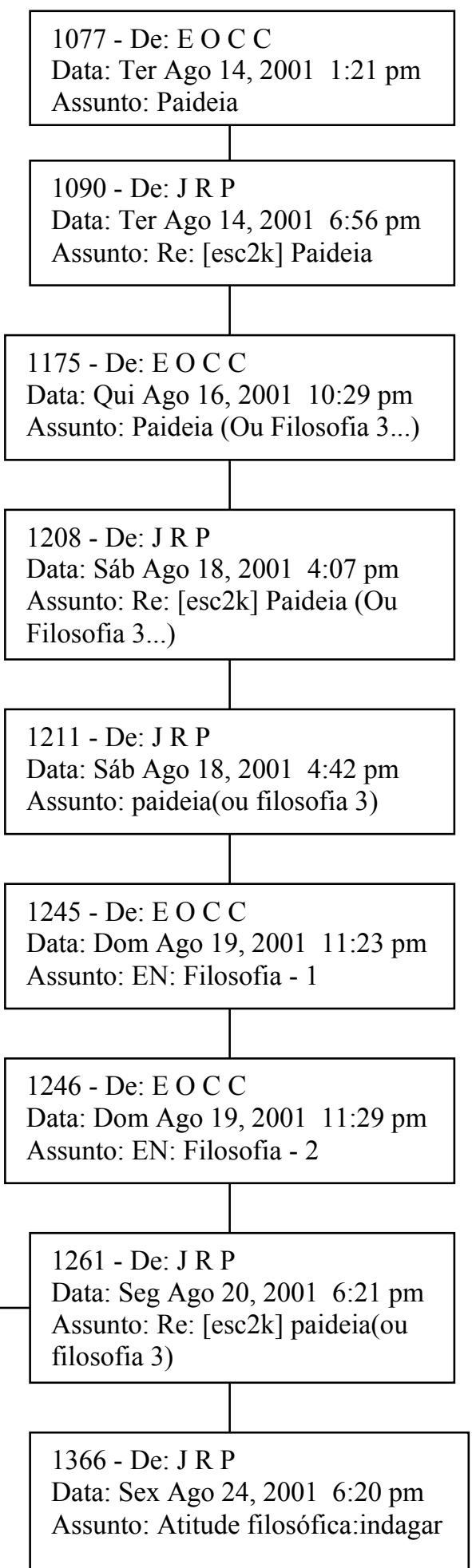




\section{T e i a 21}

Título - Martin Luther King

Essa teia é formada por 9 mensagens e 3 participantes no período de 17 a 28 de agosto.

O ciclo de conversas se inicia a partir de um e-mail no qual seu remetente conta que está escrevendo um livro sobre sonhos e que usa como base de inspiração o discurso "I have a dream" de Martin Luther King. Isto gera uma serie de reflexões sobre liberdade, preconceito e racismo. Retoma-se filmes que tratam destas questões como "Mississipi em chamas" e "Hora do Show".

1201 - De: E O C C

Data: Sex Ago 17, 2001 10:58 pm

Assunto: Martin Luther King Jr: "Eu tenho um sonho"

1258 - De: J R P

Data: Seg Ago 20, 2001 5:49 pm

Assunto: Re: [esc2k] Martin Luther King Jr: "Eu tenho um sonho"

1260 - De: O N

Data: Seg Ago 20, 2001 6:01 pm

Assunto: Re: [esc2k] Martin Luther King Jr: "Eu tenho um sonho"

1262 - De: J R P

Data: Seg Ago 20, 2001 6:25 pm

Assunto: Re: [esc2k] Martin Luther King Jr: "Eu tenho um sonho"
1292 - De: E O C C

Data: Ter Ago 21, 2001 10:29 am

Assunto: I Have a Dream - ouca e veja

294 - De: E O C C

Data: Ter Ago 21, 2001 11:33 am

Assunto: RE: [edutec] I Have a Dream - ouca e veja

1419 - De: J R P

Data: Ter Ago 28, 2001 5:33 pm

Assunto: I HAVE A DREAM

Data: Ter Ago 21, 2001 6:25 pm
Assunto: Re: [esc2k] Martin Luther King Jr: "Eu tenho um sonho" 


\section{T e i a 22}

Título - Comunique-se corretamente com o surdo

Essa teia é formada por 9 mensagens e 3 participantes, no período de 28 de julho a 12 de agosto.

A conversação se inicia a partir de um e-mail da Escola Normal de Taguatinga/DF que visa apresentar um manual de comunicação entre ouvintes e surdos, com o propósito de facilitar este processo. A partir daí os participantes do fórum refletem sobre as questões relacionadas ao surdos e o desprepado da sociedade para integrá-los ao cotidiano. Algumas mensagens apresentam interferências desta condição na comunicação escrita. Discute-se a importância do conhecimento de LIBRAS. Fica em suspenso um convite para integrar mais pessoas surdas à lista de discussão.

Diagrama da Teia 22

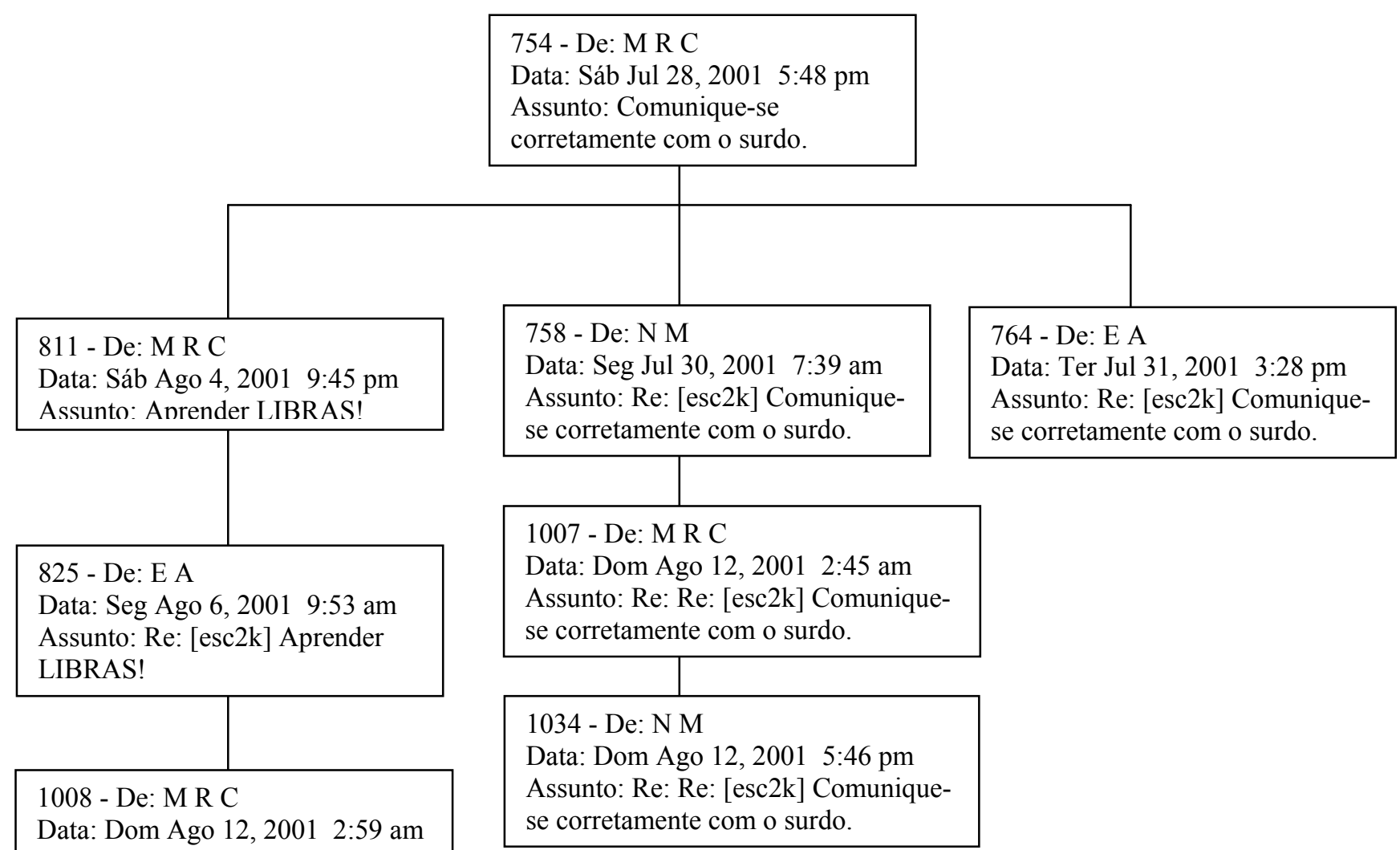




\section{T e i a 23}

Título - Mudança de Diretor

Essa teia é formada por 9 mensagens e 7 participantes, no período de 18 a 20 de agosto.

O ponto de partida destas mensagens é a informação de que a escola "C.E.Dom Otaviano de Albuquerque" está sob nova direção. Os integrantes do fórum dão as boas vindas às novas integrantes da escola e falam sobre a importância da educação que prepara o aluno para tornar-se um cidadão. Discutem sobre o programa "Sua escola a 2000 por hora" e refletem sobre o papel do Diretor dentro de uma instituição de ensino.

Diagrama da Teia 23

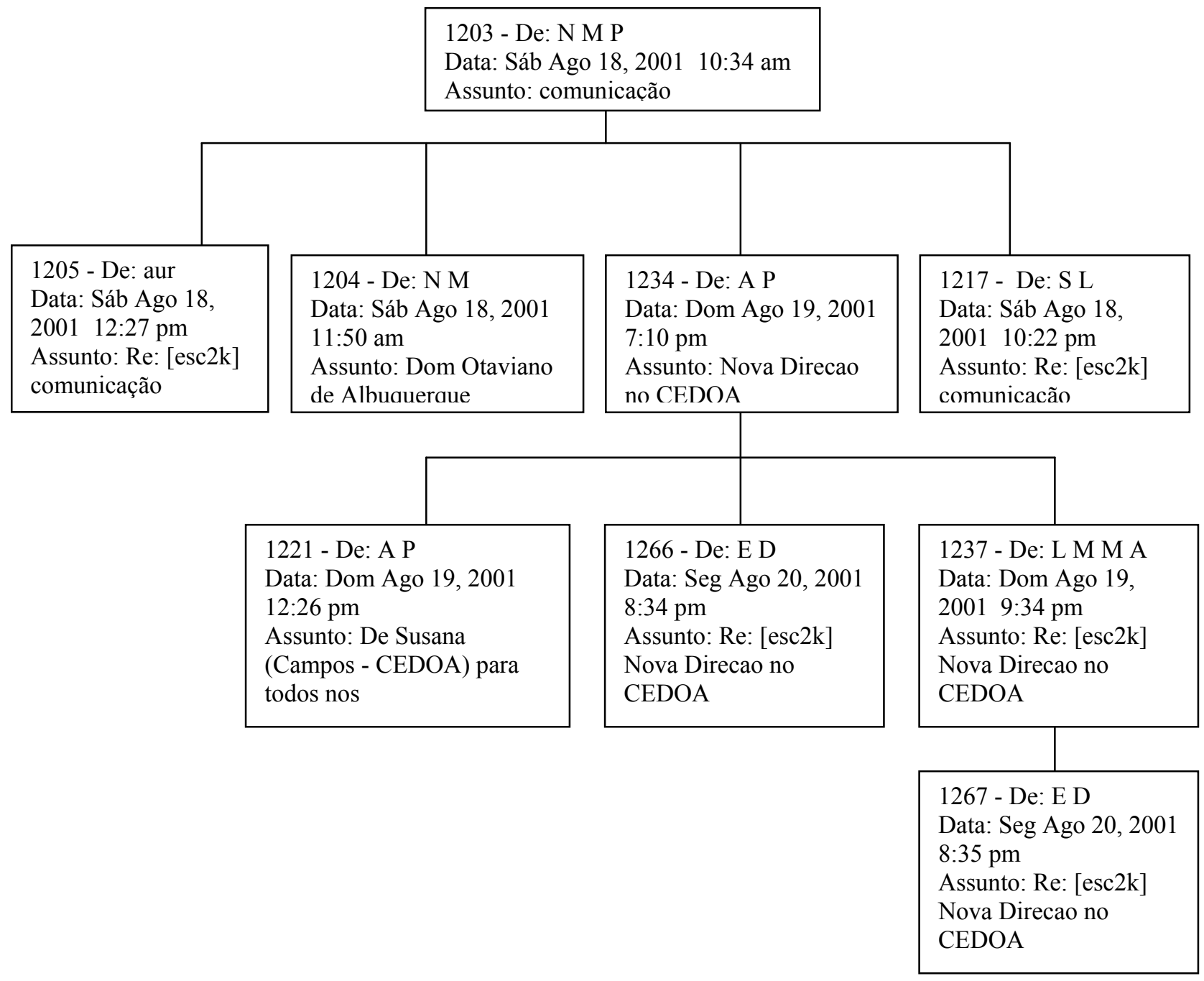




\section{T e i a 24}

Título - Oficina semeio no CEDOA

Essa teia é formada por 9 mensagens e 6 participantes, no período de 21 a 22 de agosto.

A conversação se inicia a partir da noticía sobre a Oficina de Semeio no CEDOA. A participante do fórum que inicia o ciclo de mensagens descreve como foi o evento: as escolas que participaram e o que foi realizado, destacando a importância ambiental na preservação e replantio de árvores que constituem a mata ciliar do Rio Ururaí em Campos dos Goytacazes RJ. O uso do vídeo foi importante para ilustrar situações cotidianas dos participantes do evento e iniciar um processo de reflexão e discussão dos problemas da região. Em seguida, outros participantes do fórum fizeram suas reflexões a respeito da preservação do meio ambiente e do ato de semear árvores, escolhendo a música "O Cio da Terra" para representar este processo. Discutiu-se sobre qualidade de vida, comparando-se a proximidade junto à natureza das pequenas cidades com as opções de cultura e lazer das grandes metrópoles como São Paulo. 


\section{Diagrama da Teia 24}

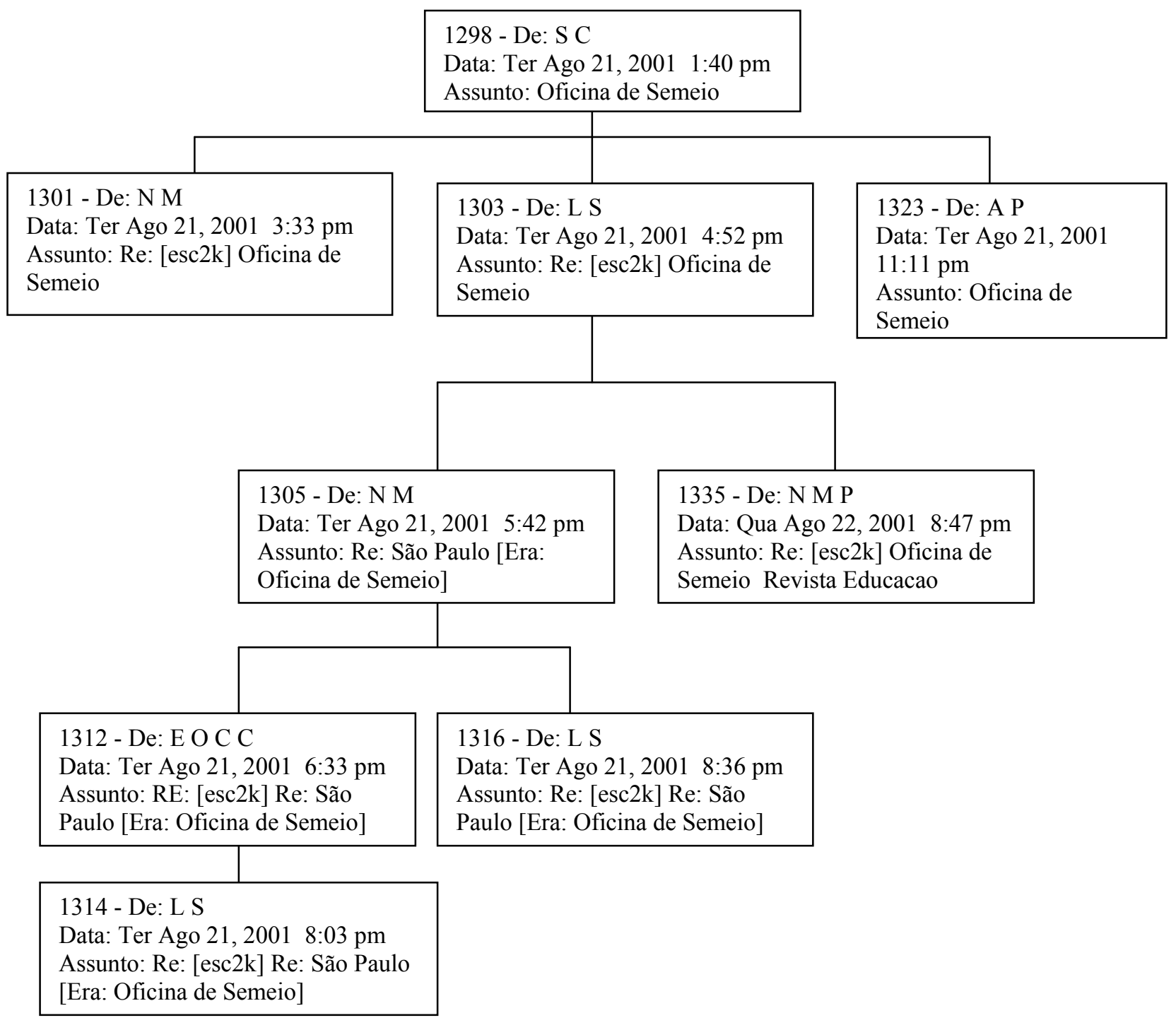




\section{T e i a 25}

Título - Site Edutec

Essa teia é formada por 9 mensagens e 5 participantes, no período de 21 a 22 de agosto.

O ponto de partida destas mensagens é a comunicação da escolha do site de um dos participantes do fórum (EduTec.Net) como "site do mês" por uma revista especializada em educação. Ao consultar a revista, este participante descobriu que o site do projeto "Sua escola a 2000 por hora" também já foi escolhido como "site do mês". Discutiu-se a importância de dar visibilidade aos sites de boa qualidade e que tem o compromisso de se aprimorarem e de se reciclarem. Os demais participantes parabenizaram o homenagiado pela revista.

\section{Diagrama da Teia 25}

1285 - De: E O C C

Data: Ter Ago 21, 2001 8:41 am

Assunto: Site Edutec na Revista

Educacao

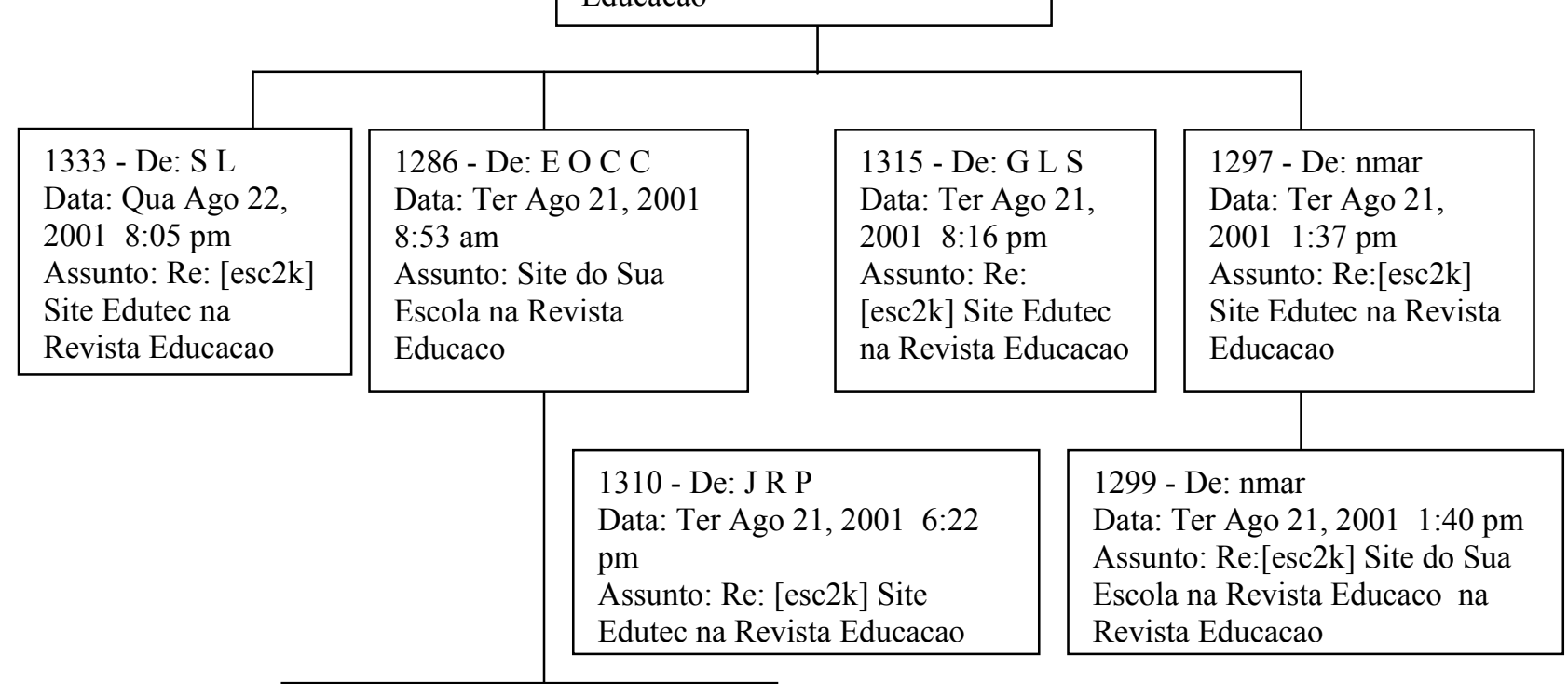

\begin{tabular}{l}
$\begin{array}{l}\text { 1287 - De: A P } \\
\text { Data: Ter Ago 21, 2001 9:37 am } \\
\text { Assunto: Re: [esc2k] Site Edutec } \\
\text { na Revista Educacao }\end{array}$ \\
\begin{tabular}{|l|}
\hline \\
1289 - De: E O C C \\
Data: Ter Ago 21, 2001 9:44 am \\
Assunto: RE: [esc2k] Site Edutec \\
na Revista Educacao
\end{tabular} \\
\hline
\end{tabular}




\section{T e i a 26}

\section{Título - Festsesi em Araxá}

Essa teia é formada por 9 mensagens e 5 participantes, no período de 30 a 31 de agosto, cujo ponto de partida é a mensagem de uma professora convidando todos os assinantes para XI Edição do Festival de Dança do SESI - Araxá, no período de 2 a 9 de setembro. Essa mensagem gera algumas mensagens sobre a cultura regional e outras sobre $\mathrm{o}$ funcionamento do sistema e a necessidade de os assinantes se identificarem e deixar claro a que mensagem eles estão se referindo.

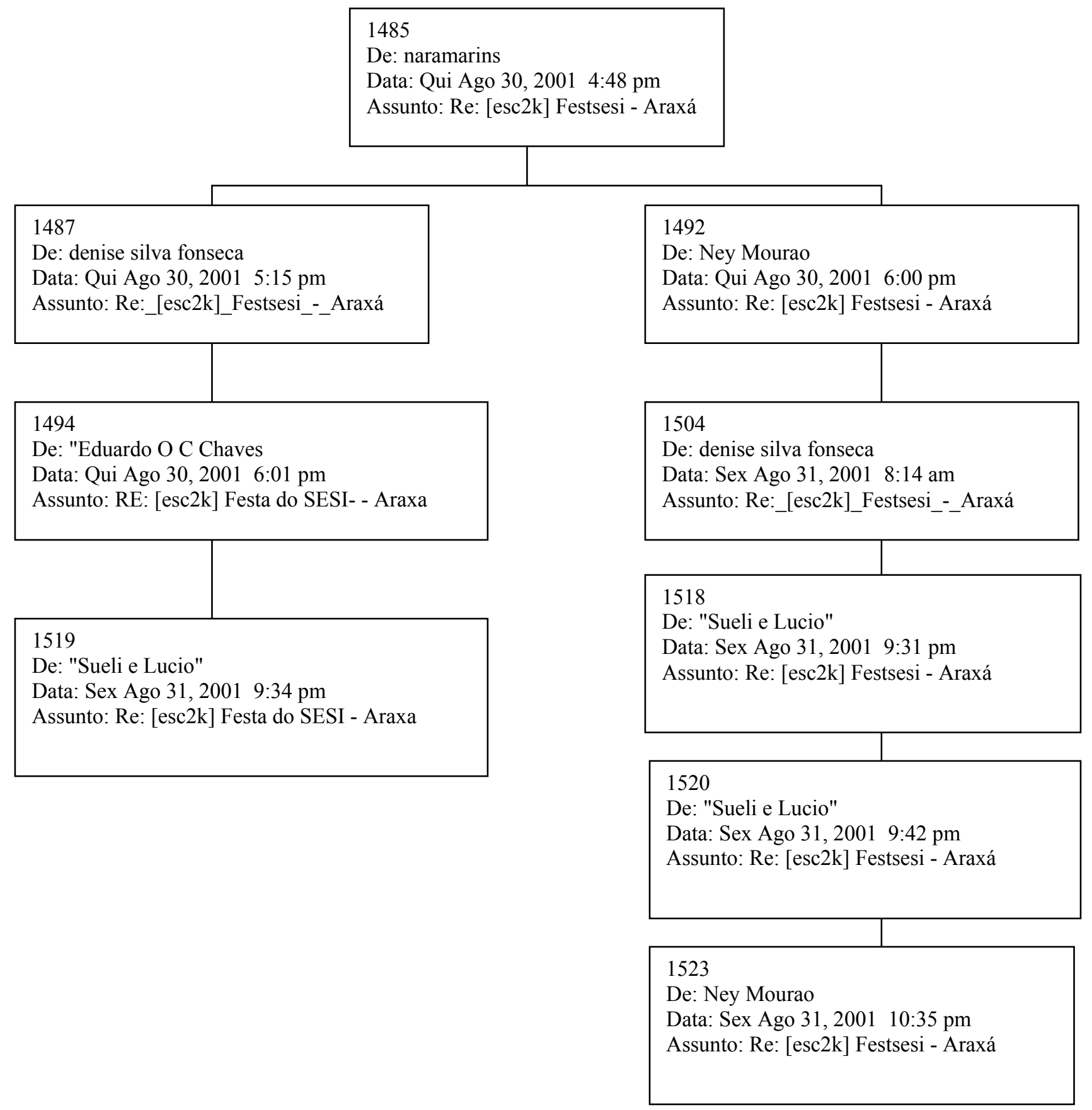




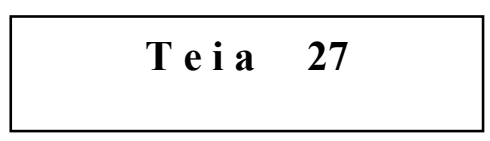

Título - Projeto jornal

Essa teia é formada por 8 mensagens e 4 participantes, no período de 9 a 14/8.

A conversa se inicia a partir do pedido de auxílio de uma das participantes do fórum para o desenvolvimento do projeto de dois jornais em sua escola: um geral e outro ecológico, a ser trabalhado junto aos alunos da $8^{\text {a }}$. série. Além disso, pede ajuda para desenvolver o tema "protagonismo juvenil". É sugerido que a participante entre em contado com professoras de outras escolas que estão desenvolvendo projetos semelhantes e são indicados sites que tratam desses assuntos. Levanta-se o assunto de como fazer uma busca na internet.

\section{Diagrama da Teia 27}

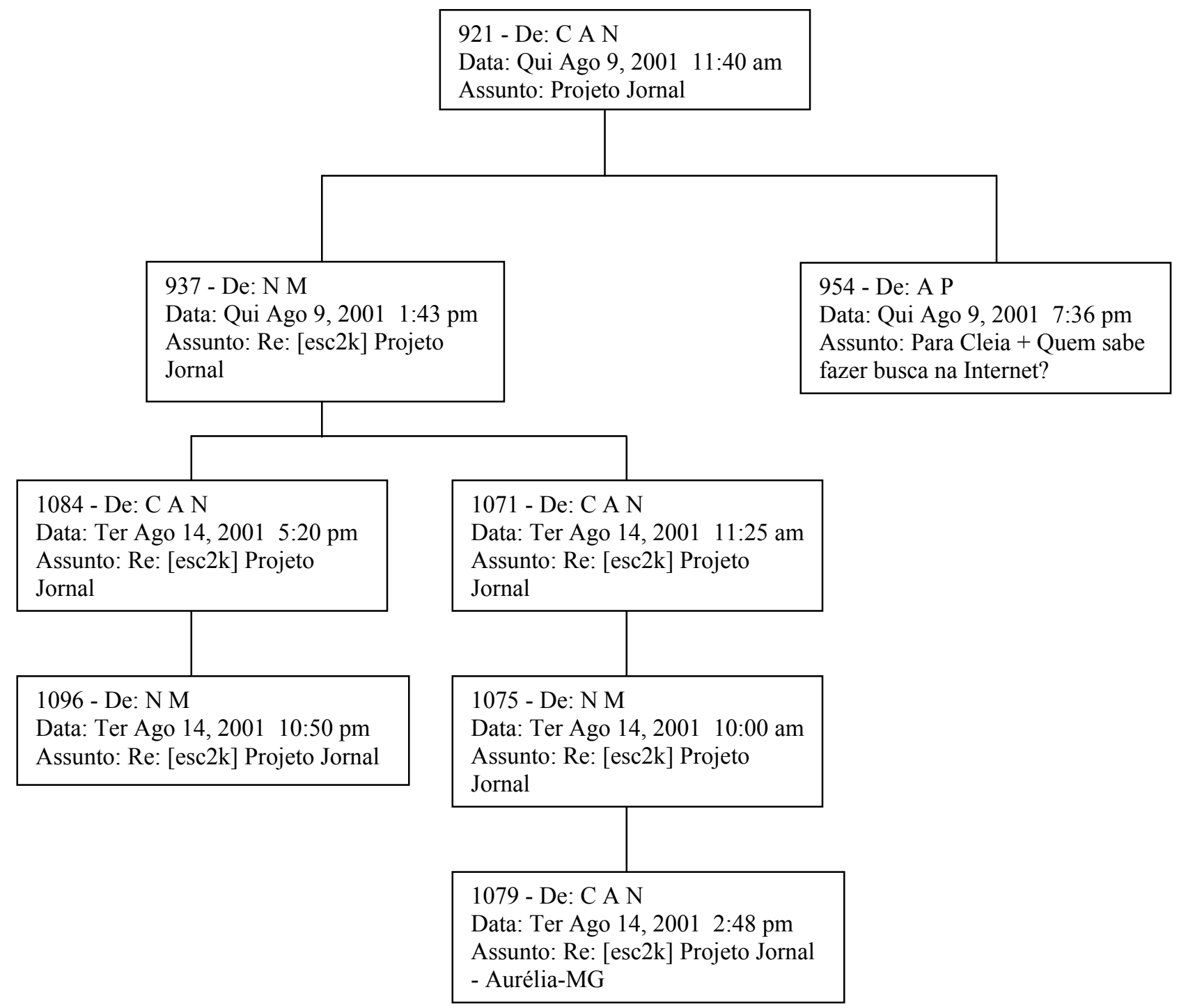




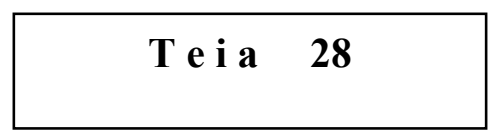

Título- Palestra da J.R.P. no Crato

Essa teia é formada por 8 mensagens e 4 participantes, no período de 21 a 22/8.

A conversação se inicia com uma das participantes contando do convite que ela e dois participantes do grêmio de sua escola receberam para dar uma palestra na escola EEFM José Alves de Figueredo, no Crato-CE. A palestra era a respeito de formação de um grêmio e "protagonismo juvenil". Em seguida, discutiram a respeito do nervosismo gerado por falar em público. Os demais participantes parabenizaram o convite para a palestra. A participante que iniciou a teia conta sobre sua experiência com outras escolas nas quais também palestrou e como estava o desenvolvimento do grêmios alí implantado.

\section{Diagrama da Teia 28}

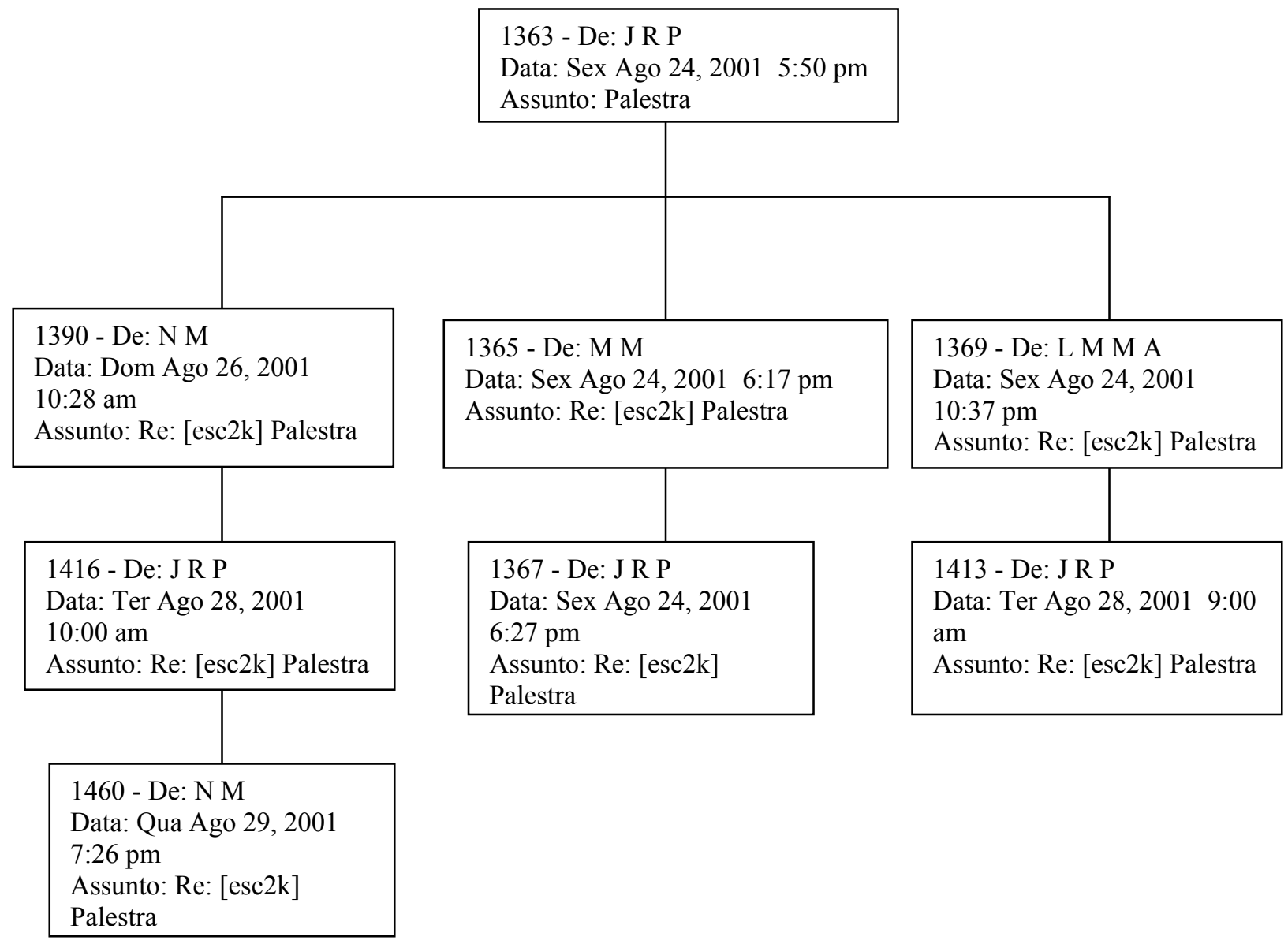




\section{T e i a 29}

Título - Sobre Belo Horizontinos

Essa teia é formada por 7 mensagens e 4 participantes no período de 11/8 a 16/8.

A conversação inicia-se a partir de um texto que fala sobre as peculiaridades dos habitantes de Belo Horizonte - MG. A partir daí os participantes retomam características culturais desta população, principalmente sobre a modalidade oral da língua e o vocabulário.

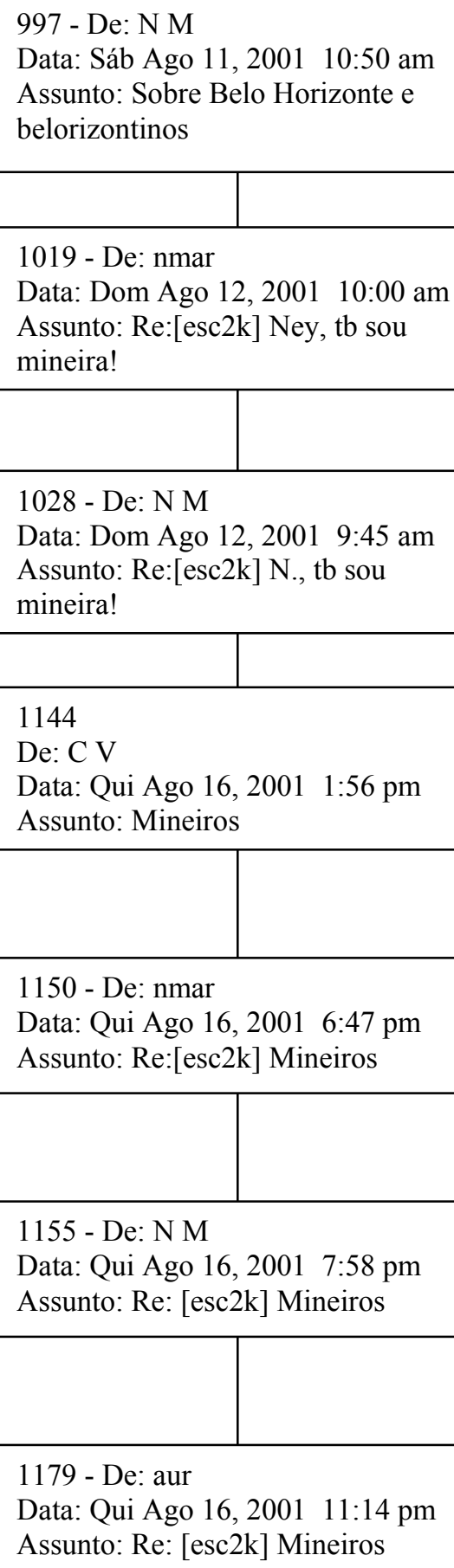




\section{T e i a 30}

\section{Título - Rádio na escola}

Essa teia é formada por 7 mensagens e 5 participantes, no período de 16 a 21 de agosto.

O ponto de partida dessas mensagens é a noticia da rádio comunitária criada na escola da participante do fórum. Ao final da mensagem, a participante solicita aos demais dicas de como organizar a a programação da rádio. Outro participante conta sua experiência junto a outra rádio comunitária e indica pessoas que sabem lidar com este assunto, e que já foi tema de reportagem em um portal de educação. Um assinante do Ceará faz um convite a todos para que conheçam sua rádio na internet e recebe resposta de quem ouviu, gostou e pede que ela explique a todos como se faz.

Diagrama da Teia 30

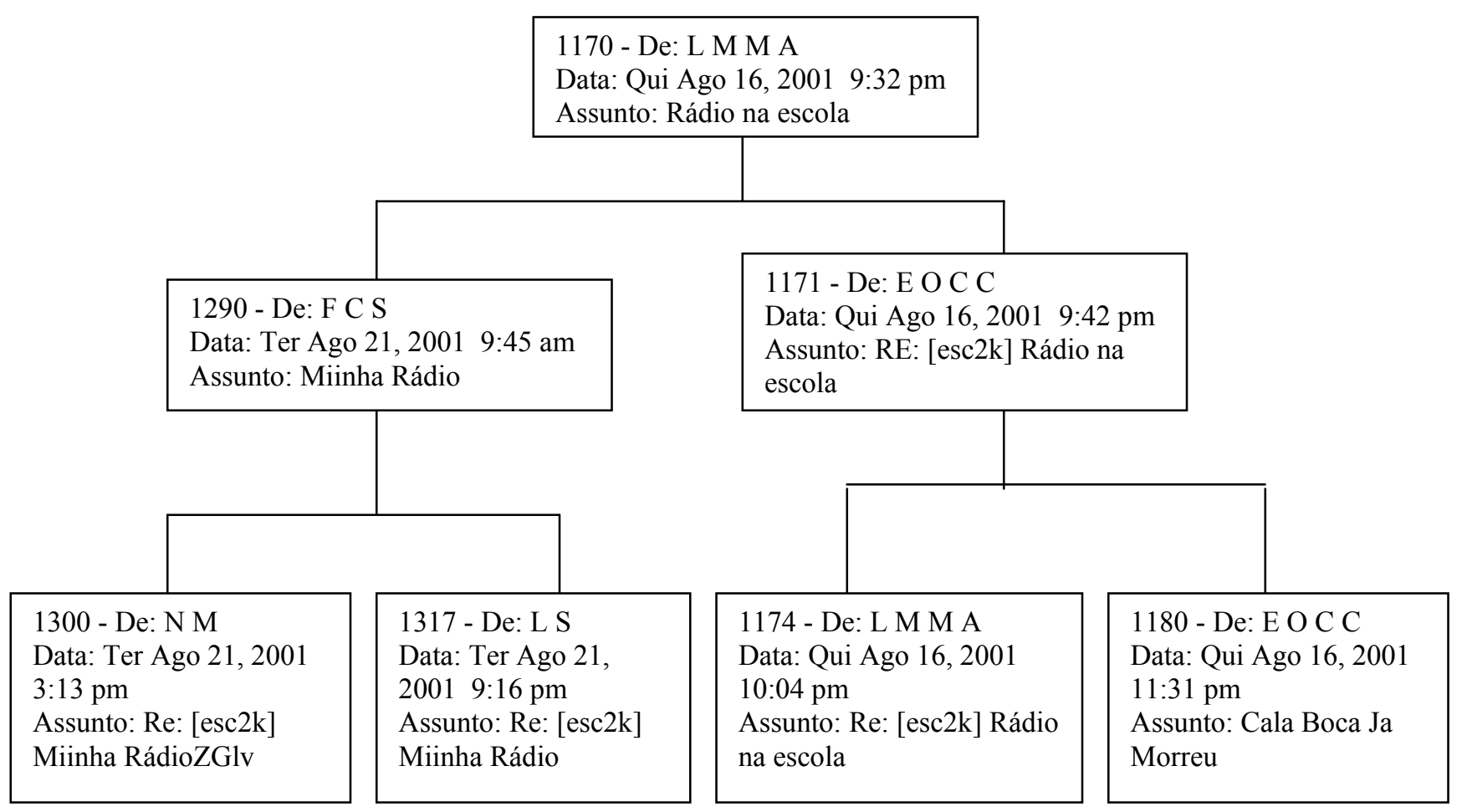




\section{T e i a 31}

Título - Dia do estudante

Essa teia é formada por 7 mensagens e 5 participantes, no período de 10 a 14 de agosto.

A conversação se inicia com uma mensagem de congratulação pelo dia do estudante a aqueles que fazem parte da comunidade virtual de educação, pois a assinante considera que todos são eternos estudantes. Em seguida, utilizam os pensamentos de Rubem Alves para refletir sobre a necessidade de participação do aluno no processo educativo, para que ocorra aceitação e assimilação dos conteúdos apresentados pelos professores. Cita-se também as considerações de Guimarães Rosa sobre o assunto. Outra participante dedica um poema para os demais e a teia termina com a narração da gincana comemorativa do dia do estudante que ocorreu na escola EEFM Estado da Bahia.

Diagrama da Teia 31

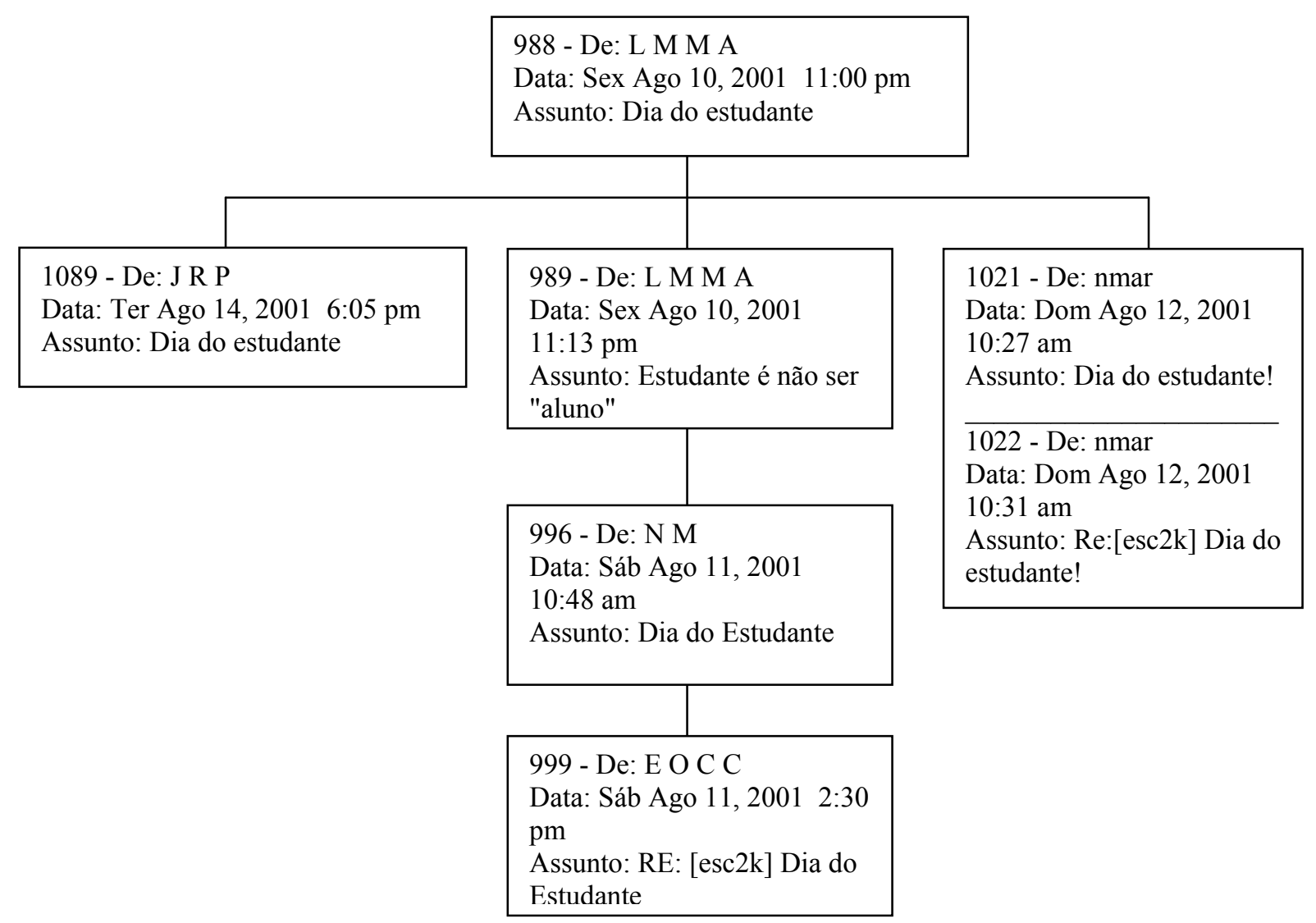




\section{T e i a 32}

\section{Título - Comemoração}

Essa teia é formada por 6 mensagens e 5 participantes no dia 7 de agosto

A conversação se inicia com um participante do fórum agradecendo a resposta que outro lhe enviou e o apoio que lhe deu em sua nova jornada. Um outro participante manifesta seu desagrado com e-mails que só podem ser entendidos por alguns, pois não faz referência à conversa anteriormente travada. Pergunta o que está sendo conversado entre os dois primeiros. Mais um participante manifesta sua curiosidade sobre o assunto. Desta forma, os dois primeiros percebem que as outras pessoas que participam do fórum querem estar a par dos fatos, não cabendo no fórum mensagens particulares. Sendo assim, esclarecem que a resposta e o apoio se referiam à nova jornada como monitor do laboratório de informática da escola em que um deles trabalha. A partir daí pode receber o apoio de outros participantes e compartilhar experiências.

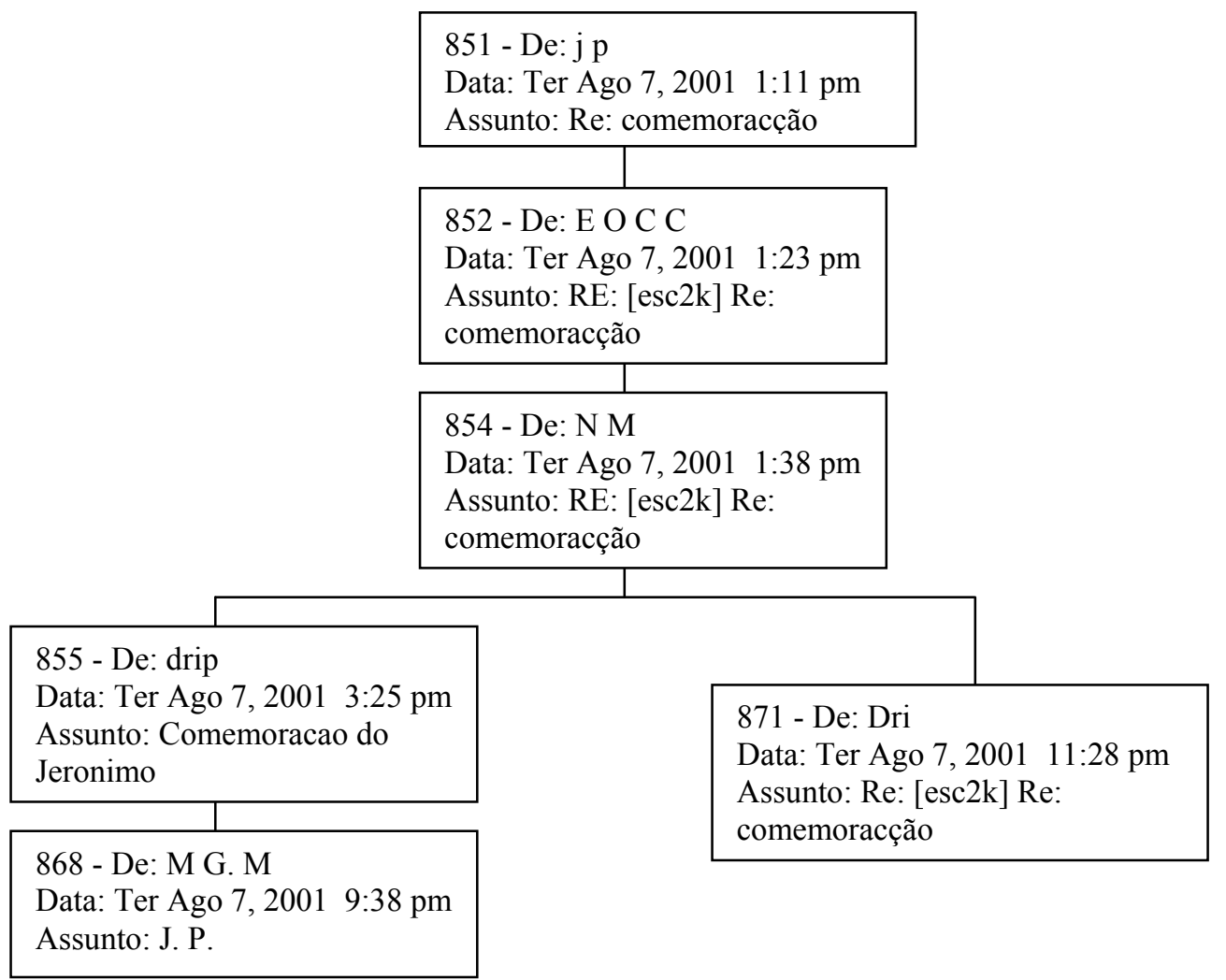




\section{T e i a 33}

\section{Título - Água no Jornal Nacional}

Essa teia é formada por 6 mensagens e 5 participantes no período de 28 a 31 de agosto.

O ponto de partida é uma mensagem a respeito do ciclo de reportagens que seriam apresentadas no Jornal Nacional da Rede Globo a respeito do uso da água. O participante que envia a mensagem chama atenção para a importância de se debater esse assunto no âmbito das escolas que os participantes do fórum trabalham, devido aos problemas que enfrentam com captação de água, tratamento de esgoto, destruição das margens dos rios, entre outros. Outro participante informa que em sua escola estão trabalhado tanto este como outros assuntos, como por exemplo, o pré-vestibular só para negros. Coloca-se para o grupo que a internet é uma fonte riquíssima para obter informações a respeito da água. Sugere-se que esse assunto seja tema de debate entre as escolas e que poderiam usar a sala de chat do "Programa sua escola a 2000 por hora" para fazê-lo.

1464 - De: N M

Data: Qua Ago 29, 2001

$8: 15 \mathrm{pm}$

Assunto: Re: [esc2k] Agua no JN
1430 - De: A P

Data: Ter Ago 28, 2001 8:58 pm

Assunto: Agua no JN

1453 - De: aur

Data: Qua Ago 29, 2001 4:14 pm

Assunto: Re: [esc2k] Agua no JN

1457 - De: A P

Data: Qua Ago 29, 2001 6:18

pm

Assunto: Re: [esc2k] Agua no

JN

1522 - De: eu

Data: Sex Ago 31, 2001 10:06 pm

Assunto: "Água"

1458 - De: $\lg$

Data: Qua Ago 29, 2001 7:02

pm

Assunto: Re: Agua no JN 


\section{T e i a 34}

Título - Monitores

Essa teia é formada por 5 mensagens e 5 participantes, no período de 23 a 25 de agosto.

A teia se inicia com uma mensagem sobre o novo cargo de monitora do laboratório de informática do CEDOA que uma das participantes da lista passa a assumir. Em seguida, é parabenizada pelos colegas e questionada sobre como tudo ocorreu. Alguns assinantes compartilham suas próprias experiências nesta mesma função em suas escolas.

Diagrama da Teia 34

1348 - De: E D

Data: Qui Ago 23, 2001

2:51 pm

Assunto: Re: [esc2k]

monitores
1342 - De: L F m

Data: Qui Ago 23, 2001 11:06 am

Assunto: monitores
1381 - De: S L

Data: Sáb Ago 25, 2001 6:54 pm

Assunto: Re: [esc2k] monitores
1385 - De: N M

Data: Sáb Ago 25,

2001 11:41 pm

Assunto: Re: [esc2k]

monitores 


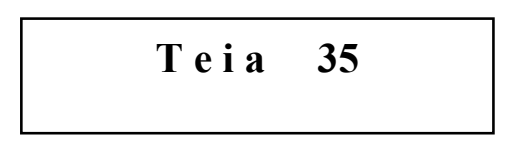

Título - Discriminação em combate a driscriminação

Essa teia é formada por 5 mensagens e 4 participantes, no período de 28 a 30 de agosto.

O ponto de partida da teia é uma mensagem sobre a condição do negro no ensino superior, principalmente a questão do governo propor cotas especiais para negros nas universidades públicas e de criar cursos pré-vestibulares específicos para os mesmos . A assinate que envia a mensagem conta sobre sua experiência na universidade e do baixo número de negros que conseguia encontrar frequentando este nível da formação escolar. Assim, propõe iniciarem um debate a respeito do assunto. Afirma que considera este um processo discriminatório e acredita que melhorias significativas no ensino fundamental e médio possibilitariam tratar a questão de forma mais justa e digna com os envolvidos. Considera que o maior problema está na falta de condições financeiras para que esta parte da população obtenha a formação necessária para disputar uma vaga no ensino superior público. Um participante conta sobre a pesquisa de opinião feita por uma rádio que indica um posicionamento do público contra o sistema de cotas. No entanto, sua opinião pessoal é a favor do sistema de cotas e cursinho para negros, pois considera que seria uma forma de acelerar o processo proposto por essas ações afirmativas, não desconsiderando a necessidade de melhoria no ensino fundamental e médio. Conta que passou a ser a favor depois de frequentar uma universidade americana que possui um sistema similar. Outros participantes dão sua opinião e mostram como o assunto é complexo e merece muita discussão e reflexão. Uma notícia vinculada pela imprensa nos jornais Correio Brasiliense, na Folha de São Paulo e em $O$ Globo são apresentados para ilustrar a posição e as ações do governo. 


\section{Diagrama da Teia 35}

1433 - De: Dri

Data: Ter Ago 28, 2001 11:29 pm

Assunto: En: [esc2k-08]

Discriminação em combate a

discriminacão

1439 - De: O N

Data: Qua Ago 29, 2001

$12: 22 \mathrm{pm}$

Assunto: Re: [esc2k] En:

[esc2k-08] Discriminação

em combate a

discriminação

1495 - De: O N

Data: Qui Ago 30, 2001

6:20 pm

Assunto: Mais Sobre Cotas

e Racismo
1454 - De: aur

Data: Qua Ago 29, 2001 4:26 pm

Assunto: Re: [esc2k] En: [esc2k-08]

Discriminação em combate a

discriminação
1471 - De: d s f

Data: Qui Ago 30, 2001 9:01 am

Assunto: Re: [esc2k] Agua no JN 


\section{T e i a 36}

Título - Dias dos Pais

Essa teia é formada por 5 mensagens e 3 participantes, no período de 10 a 17 de agosto.

A teia se inicia com um participante enviando um abraço a todos os pais que participaram da lista de discussão, pois se comemorava o Dia dos Pais. Outra participante inclui na lista a mensagem que dedicou aos pais na reunião de pais que houve na sua escola. Em seguida, outros participantes contam suas experiências com o trabalho desenvolvido entre pais e alunos em suas escolas. Concluem que a participação dos pais tem aumentado em algumas escolas em quantidade e em todas em qualidade, e que isto é muito importante no processo de formação do aluno.

Diagrama da Teia 36

979 - De: J R P

Data: Sex Ago 10, 2001 5:48 pm

Assunto: Dia dos pais
1023 - De: nmar

Data: Dom Ago 12, 2001 10:46 am

Assunto: Re:[esc2k] Aos papais!
1027 - De: N M

Data: Dom Ago 12, 2001

8:13 am

Assunto: Feliz Dia dos Pais

1126 - De: nmar

Data: Qua Ago 15, 2001 9:36 pm

Assunto: Re:_[esc2k]_Pais na

escola

1190 - De: C A N

Data: Sex Ago 17, 2001 3:09 pm

Assunto: Re: Encontro em

Charqueadas-RS 


\section{T e i a 37}

Título - Agapedia: Pedagogia do amor

Essa teia é formada por 5 mensagens e 2 participantes, no dia 15 de agosto.

Quatro reportagens escritas enviadas por um assinante com o comentário de uma outra assinante.

\section{Diagrama da Teia 37}

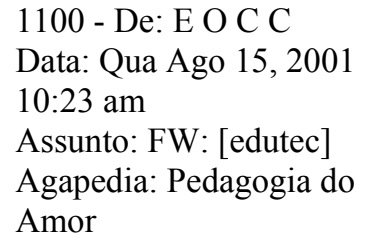

1103 - De: E O C C

Data: Qua Ago 15, 2001

10:59 am

Assunto: Anulacao de

Casamento por

Desconhecimento do

Desvirginamento Previo
1104 - De: E O C C

Data: Qua Ago 15, 2001

11:07 am

Assunto: Infelidelidade

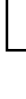

1105 - De: E O C C Data: Qua Ago 15, 2001 11:10 am Assunto: Direitos Sexuais Humanos

1131 - De: nmar

Data: Qua Ago 15, 2001 10:31 pm

Assunto: Re: [esc2k] Para Eduardo 